UNIVERSIDADE DE SÃO PAULO

INSTITUTO DE PSICOLOGIA

MONICA MARIA DE ANGELIS MOTA

\title{
O LUTO EM ADOLESCENTES PELA MORTE DO PAI: RISCO E PREVENÇÃO PARA A SAÚDE MENTAL
}


MONICA MARIA DE ANGELIS MOTA

\section{O LUTO EM ADOLESCENTES PELA MORTE DO PAI: RISCO E PREVENÇÃO PARA A SAÚDE MENTAL}

Tese apresentada ao Instituto de Psicologia da Universidade de São Paulo para a obtenção do título de Doutor em Psicologia.

Área de concentração: Psicologia Clínica Orientadora: Prof. ${ }^{a}$ Dra. Elizabeth Batista Wiese

São Paulo

2008 


\section{AUTORIZO A REPRODUÇÃO E DIVULGAÇÃO TOTAL OU PARCIAL DESTE TRABALHO, POR QUALQUER MEIO CONVENCIONAL OU ELETRÔNICO, PARA FINS DE ESTUDO E PESQUISA, DESDE QUE CITADA A FONTE.}

Catalogação na publicação

Serviço de Biblioteca e Documentação

Instituto de Psicologia da Universidade de São Paulo

Mota, Monica Maria de Angelis.

O luto em adolescentes pela morte do pai: risco e prevenção para a saúde mental /Monica Maria de Angelis Mota; orientadora Elizabeth Batista Wiese. --São Paulo, 2008.

$231 \mathrm{p}$.

Tese (Doutorado - Programa de Pós-Graduação em Psicologia. Área de Concentração: Psicologia Clínica) - Instituto de Psicologia da Universidade de São Paulo.

1. Luto 2. Adolescência 3. Pai 4. Família 5. Trauma emocional I. Título.

BF575.G7 


\section{FOLHA DE APROVAÇÃO}

Monica Maria de Angelis Mota

O luto em adolescentes pela morte do pai: risco e prevenção para a saúde mental

Tese apresentada ao Instituto de Psicologia da Universidade de São Paulo para a obtenção do título de Doutor em Psicologia.

Área de concentração: Psicologia Clínica

Orientadora: Prof. ${ }^{\text {a }}$ Dra. Elizabeth Batista Wiese

Aprovada em:

\section{Banca Examinadora}

Prof. Dr.:

Instituição: Assinatura:

Prof. Dr.:

Instituição: Assinatura:

Prof. Dr.:

Instituição:

Assinatura:

Prof. Dr.:

Instituição:

Assinatura:

Prof. Dr.:

Instituição: Assinatura: 
A meu pai Joecyl, por seu exemplo de perseverança, minha eterna admiração.

A meu pai Bruno, cuja generosidade despertou meu amor filial.

A minha mãe, Nice, por sua força e apoio na hora mais dificil de nossas vidas, meu reconhecimento sem fim. 


\section{Agradecimentos}

À minha orientadora, Prof ${ }^{\mathrm{a}}$ Dr $^{\mathrm{a}}$ Elizabeth Batista Wiese, por acreditar em mim. Sua dedicação e paciência foram fundamentais para a realização deste trabalho.

À Prof ${ }^{a}$ Dr Maria Júlia Kovács, por seu apoio nas horas mais difíceis, contribuindo com intervenções sempre ágeis, seguras e produtivas.

À Prof $f^{a}$ Dr Cleusa Sakamoto, companheira de trabalho, presença sempre confiável e criativa.

À Prof ${ }^{a}$ Dr Leila Tardivo, que há tanto tempo acompanha minha vida profissional, sempre me aconselhando, estimulando e acolhendo com extrema generosidade, minha gratidão eterna.

À Prof ${ }^{a}$ Gabriela Caselllato, pelas preciosas sugestões.

Aos jovens que participaram desta pesquisa, pela generosidade e pelo envolvimento com a proposta. Sem vocês, este trabalho não teria sentido.

Aos meus alunos e pacientes, com quem sempre aprendo muito, vivendo trocas intelectuais e de afeto que me fazem refletir e aprender sobre a vida, mantendo-me estimulada e esperançosa.

Às colegas do Mackenzie, pelo apoio e pela paciência com que me acompanharam nessa jornada, pela amizade carinhosa e imprescindível, mulheres e profissionais que admiro e nas quais me espelho.

As colegas de doutorado, Aicil Franco, Adriana Tannus e Denise Monteiro, sempre generosas e compreensivas.

À instituição que me acolheu e me permitiu trabalhar com seus alunos, particularmente ao corpo diretivo, aos psicólogos e à assistente social.

Às pessoas que colaboraram comigo para a realização deste trabalho, na leitura do texto, nas transcrições e traduções, em especial, Aparecida Fusaro, amiga do coração, Helena Meidani, cuja eficiência e profissionalismo me fizeram aprender a admirá-la, e Renata Freire, psicóloga, querida companheira de consultório. 
A meus pais Joecyl (in memoriam), Bruno e Berenice, a quem admiro profundamente. A vida foi generosa, ao me permitir ser orientada por essas pessoas, que tanto e tão bem se dedicaram a mim.

Ao César, que, com seu amor e companheirismo, me apoiou no momento mais difícil desta empreitada, por sua inesgotável paciência, e que, com sua simplicidade, me fez aprender a olhar para as estrelas e sonhar.

A minha irmã Valeska, pelo estímulo constante.

Às amigas Solange Souza, Solange Henriques, Fernanda Baleeiros, Cristina e Sueli, que, com seu companheirismo, em muitos momentos me deram o necessário suporte.

Ao Carlos, que tanto acreditou na minha capacidade de atingir meus objetivos, meu carinho e minha gratidão por tudo o que com ele aprendi. 
Tem tanta gente ruim no mundo....

É um pensamento chato, feio e egoísta, né?

Mas, sei lá, não quero isso pra ninguém, é horrível. É horrivel, horrivel, horrivel. Porque pai é pai, mãe é mãe, você vai sentir falta, né? A minha mãe com tudo, com tudo, eu amo ela e ela é a melhor mãe do mundo, sabe? Acho que é normal. K. 


\section{RESUMO}

MOTA, M. M. A. O luto em adolescentes pela morte do pai: risco e prevenção para a saúde mental, 2008. 231f. Tese (Doutorado) - Instituto de Psicologia, Universidade de São Paulo, São Paulo, 2008.

Este estudo explora, descreve e discute a vivência de luto de cinco adolescentes que perderam o pai biológico por morte de causas diversas. Para tanto, investigaram-se vivências e manifestações relacionadas a essas experiências de perda, suas repercussões para os jovens e para seu desenvolvimento emocional, as estratégias de que eles se valeram para enfrentar esse luto, sua resiliência frente à perda vivida (capacidade do jovem de resistir às adversidades geradas pela morte do pai, adaptar-se e manter-se psicologicamente saudável), identificandose fatores de risco (vulnerabilidades) e de proteção para a elaboração desse luto e o desenvolvimento dos adolescentes, bem como a necessidade ou não de se proporem formas de cuidado específicas para os enlutados, entre as inúmeras possibilidades terapêuticas, mesmo que profiláticas. Como procedimento, usaram-se o Inventário de Auto-avaliação para jovens de 11 a 18 anos (YSR), para rastrear a eventual presença de problemas de saúde mental, e uma entrevista semi-estruturada com roteiro. A análise dos dados obtidos estabeleceu que o luto pela morte do pai biológico na adolescência tem características próprias, distinguindo-se do luto que essa perda acarreta em outras etapas do ciclo vital, em função dos desafios singulares do desenvolvimento nesse período. Embora a morte do pai biológico represente para o adolescente uma crise, também pode ser uma oportunidade para que, no enfrentamento dessa perda, ele amadureça. Constatou-se ainda a importância do suporte social de uma rede de apoio que compreenda e atenda as necessidades do enlutado, sobretudo pela presença de uma mãe funcional, para a ressignificação dessa perda, além de que, se o adolescente tem dificuldade para expressar seu luto, pode ficar entorpecido e negar as conseqüências dessa perda, comprometendo seu desenvolvimento emocional.

Palavras-chave: 1. Luto 2. Adolescência 3. Pai 4. Família 5. Trauma 


\begin{abstract}
MOTA, M. M. A. The bereavement of adolescents for the death of father: risk and prevention for mental health, 2008. 231f. Thesis (Ph.D) - Psychology Institute, University of São Paulo, São Paulo, 2008.

This study explores, describes and discuss the bereavement experience of five adolescents who had lost their biological father by death of several causes. Thus, it was sought to investigate the experiences and events related to these experiences of loss; its impact on young people and for their emotional development; the strategies that they used to cope with this mourning; the resilience to face the loss experienced (the adolescent's ability to resist to the adversities generated by the death of the father, adapt to and remain psychologically healthy), identifying risk factors (vulnerabilities) and protection factors for the resolution of this bereavement and the development of adolescents, and if it's necessary to propose ways of special care for the bereaved, among the many therapeutic possibilities, even if prophylactic. As procedure, were used the Inventory of Self-assessment for young people from 11 to 18 years-old (YSR), to trace the possible presence of mental health problems and a semistructured interview with a script. The analysis of data obtained established that the mourning for the death of biological father in adolescence presents its own characteristics, distinguishing itself from the grief that this loss brings at other times of the life cycle, according to the natural challenges of development in that period; the fact that, although the death of the biological father represents a crisis for the adolescent, can also be an opportunity for him or her, when facing this loss, matures; The importance of social support of a supportive network that understands and meets the needs of the bereaved, especially the presence of a functional mother, for the re-signification of this loss, as well as the fact that the teenager's difficulties to express themselves about the mourning that they experience can guide them to remain numb and deny the consequences of this loss, and impair their emotional development.
\end{abstract}

Key-words: 1. Bereavement 2. Adolescence 3. Father 4. Family 5. Trauma 


\section{SUMÁRIO}

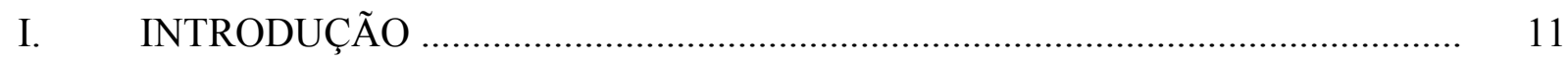

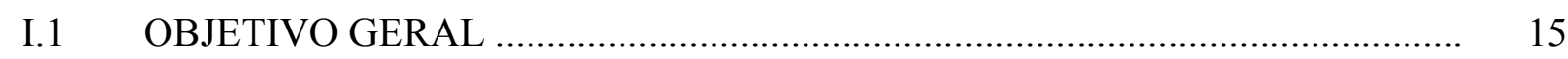

I.2 OBJETIVOS ESPECÍFICOS _.................................................................... 15

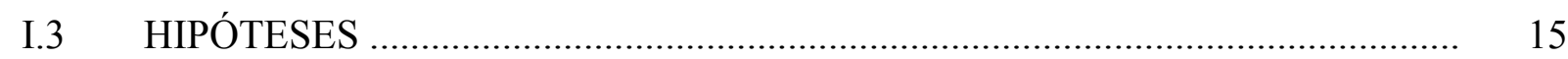

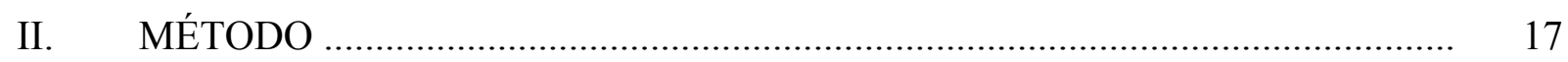

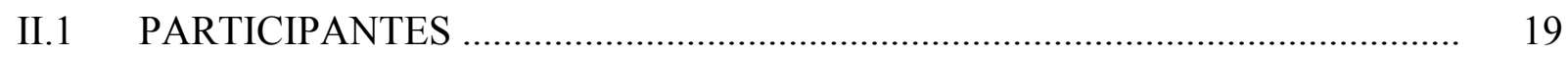

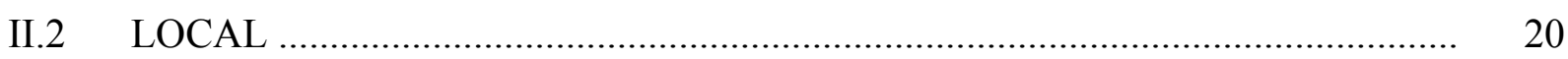

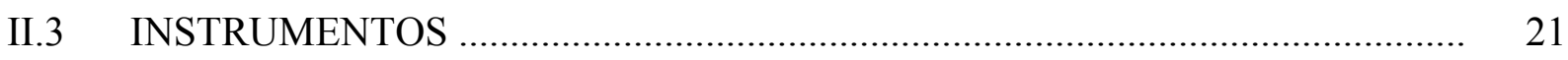

II.4 PROCEDIMENTOS PARA COLETA E ANÁLISE DE DADOS .......................... 29

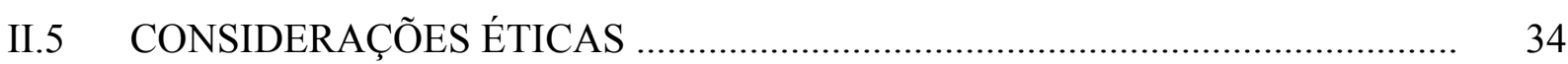

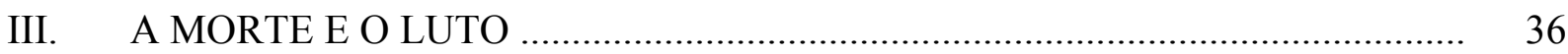

III.1 O HOMEM OCIDENTAL E A MORTE ……………………………………....... 36

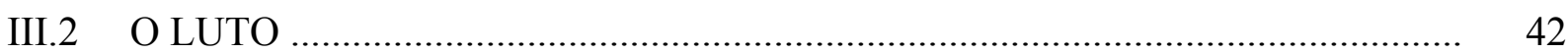

III.2.1 Apego, perda e luto .................................................................................

III.2.2 O processo de luto ........................................................................................ 47

III.2.3 O luto complicado ................................................................................... 55

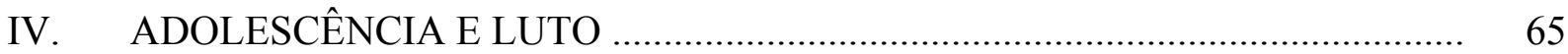

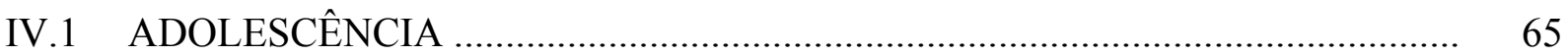

IV.2 ADOLESCENTES EM LUTO _....................................................................

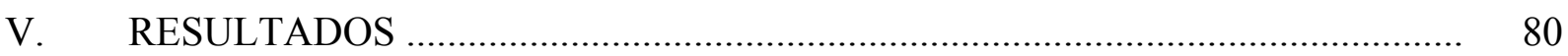

V.1 ANÁLISE DAS ENTREVISTAS ………………………………………...... 80

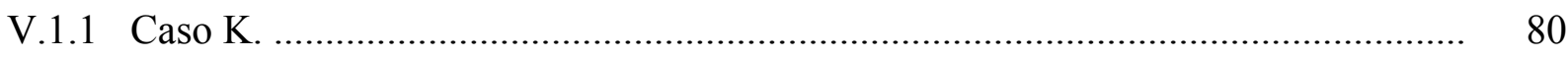

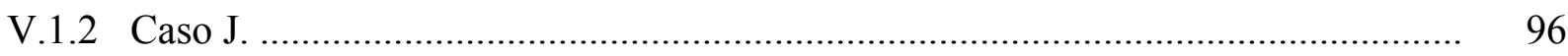

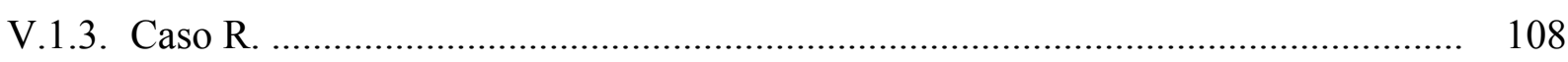


V.1.4 Caso C.

V.1.5 Caso M.

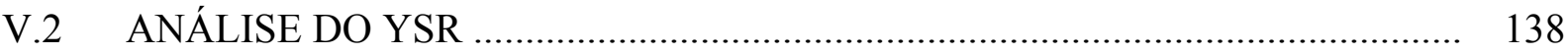

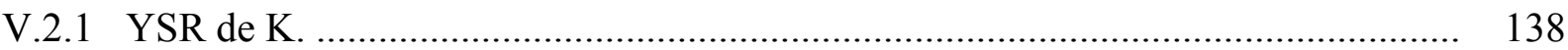

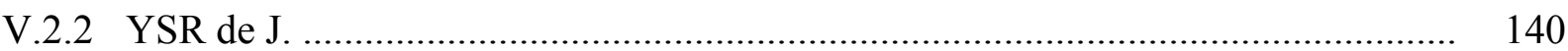

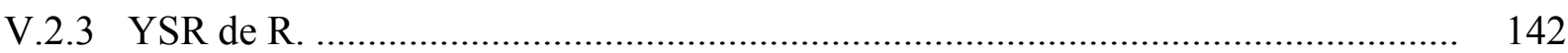

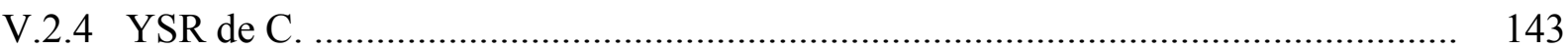

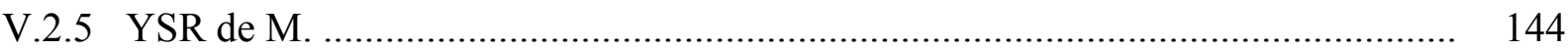

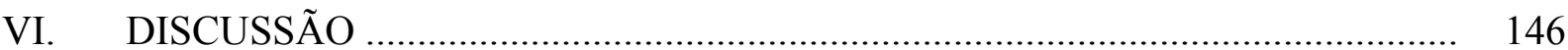

VI.1 DADOS DE IDENTIFICAÇÃO DOS ADOLESCENTES …............................... 146

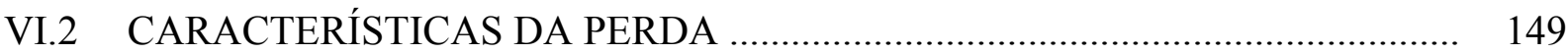

VI.3 VIVÊNCIAS E MANIFESTAÇÕES RELATIVAS À PERDA E AO PROCESSO DE LUTO …......................................................................... 153

VI.4 FATORES DE RISCO (VULNERABILIDADE) PARA LUTO COMPLICADO ..... 156

VI.5 FATORES DE PROTEÇÃO (E APOIO) PARA LUTO COMPLICADO .................... 162

VI.6 ESTRATÉGIAS DE ENFRENTAMENTO …................................................. 167

VI.7 REPERCUSSÕES DA PERDA PARA O ADOLESCENTE E SEU DESENVOLVIMENTO .......................................................................... 168

VI.8 AVALIAÇÃO DAS ENTREVISTAS _............................................................. 171

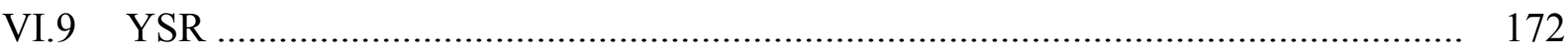

VI.10 BREVE SÍNTESE DE CADA CASO ............................................................... 173

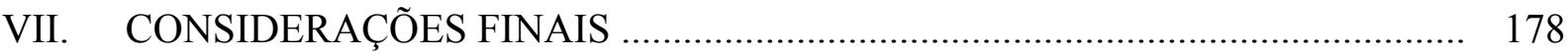

REFERÊNCIAS BIBLIOGRÁFICAS _.......................................................... 181

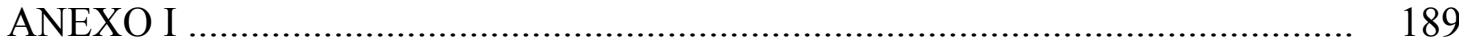

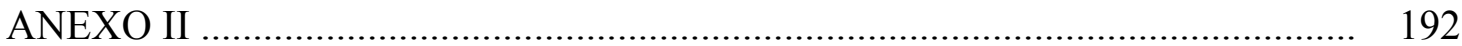

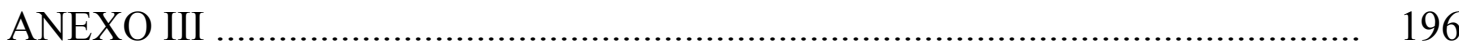

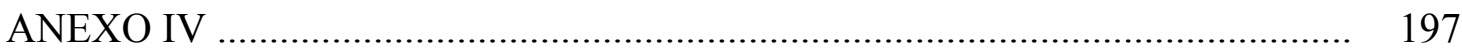

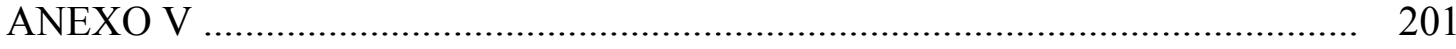




\section{INTRODUÇÃO}

A escolha de um tema de estudo é comumente marcada pela experiência de vida do pesquisador, e aqui não foi diferente. No entanto, há também outros motivos, conscientes e inconscientes, que concorreram para a eleição do tema - o luto de adolescentes que perderam seu pai biológico por morte -, dentre os que me são conhecidos.

Desde o início de minha atuação como psicóloga clínica, a princípio exclusivamente com crianças e depois também com famílias e adultos, pude constatar a importância da dinâmica das relações familiares, notadamente das relações entre pais e filhos, na constituição dos problemas vividos por meus pacientes.

Observei ainda que, ao considerar a dinâmica das relações familiares, poucas experiências podem ser tão marcantes e tão difíceis de elaborar quanto a morte de um ente querido como um pai ou uma mãe, notadamente se esta se dá precocemente, quando os filhos ainda são crianças ou adolescentes.

Além disso, há muito tempo a Psicologia tem se ocupado de estudar as relações entre mães e filhos, mas só muito recentemente focou seu interesse na figura do pai e em seu papel no desenvolvimento dos filhos. Embora isso esteja mudando, em função das reformulações que vem sofrendo a família na sociedade ocidental contemporânea, esse tema ainda carece de pesquisas.

Acresce-se que eu mesma perdi meu pai muito cedo, o que também contribuiu para que eu me sensibilizasse por esse tema tão delicado e me propusesse a estudá-lo.

Sem dúvida, falar de morte, em nossa cultura, é sempre difícil, por tratar-se de um tema ainda estigmatizado na sociedade ocidental contemporânea e que permanece quase como um tabu, apesar de essa ser uma experiência inerente à condição humana. Falar sobre essa vivência e expressar sentimentos em relação a ela são atitudes pouco estimuladas, comumente reprimidas, já que viver o luto é frequentemente visto como indigno, vergonhoso, sinônimo de fraqueza de caráter e, portanto, constrangedor e inaceitável (Domingos; Maluf, 2003; Domingos, 2000). No entanto, a morte de uma pessoa amada é uma das experiências mais dolorosas para o ser humano e evoca, além da perda em si, a idéia de aproximação da própria morte, ao trazer a tona uma ameaça à integridade do sujeito. Além disso, essa perda também pode acarretar uma série de outras com as quais o sujeito também terá que lidar (Bromberg, 2000). 
Em suas teorias sobre o vínculo, em que se articularam conceitos da etologia e da psicanálise, Bowlby (2004b) postulou o luto (em inglês, mourning) como o trabalho psíquico de elaboração da perda de um ente significativo, independentemente de seus resultados, e é com esse sentido que usaremos o termo neste estudo.

Apesar de ser uma reação normal e até mesmo esperada diante do rompimento de uma relação significativa, o luto requer um ajustamento social e faz surgirem os mais variados, profundos, intensos e primitivos sentimentos como angústia, raiva, arrependimento, saudade, medo e tristeza.

Segundo Bowlby (2004b), a vivência do luto permite a interligação entre vários processos e condições e poderia metaforicamente ser comparada a uma inflamação, condição que, segundo a medicina, também se relaciona a vários processos que - analogamente ao luto - podem resultar em cura ou em patologias.

O reconhecimento da importância desse tema tem motivado psicanalistas e psiquiatras a pesquisarem as relações entre os distúrbios psiquiátricos e a perda da pessoa amada, especialmente a perda precoce da mãe e/ou do pai (Bowlby, 2004b), freqüentemente considerada fator de vulnerabilidade para muitos dos problemas psiquiátricos da vida adulta, pois tem conseqüências profundas e duradouras na vida do enlutado (Bromberg, 2000; Parkes, 1998).

A maior parte dos estudos sobre morte precoce dos pais aborda crianças, mas, como eu já havia trabalhado com adolescentes no mestrado, optei por continuar a investigar esse universo, agora focando seu luto pela perda por morte do pai biológico (Hahn, 2005; Mota, 2003).

Para Bowlby (1997, 2004a), os adolescentes manifestam o luto como resposta à quebra de um vínculo afetivo, mas, quando essa perda se refere a uma figura que tem para eles valor de sobrevivência, essa ruptura pode eliciar uma intensa ansiedade (ansiedade de separação) e vir a influenciar a maneira como o sujeito lidará com seus vínculos e perdas futuras, bem como influenciar sua confiança básica em si, nos outros e no mundo (Bowlby, 2004b; Bromberg, 2000; Parkes, 1998).

Embora o adolescente tenha mais recursos para administrar a própria vida do que a criança e compreenda e acredite que a morte é inevitável e universal e pode, a qualquer momento, atingi-lo e àqueles que ele ama, é difícil para ele lidar concomitantemente com a perda de um ente significativo e com as demandas das tarefas inerentes a seu estágio de desenvolvimento (Pereira, 2004; Domingos; Maluf, 2003; Domingos, 2000; Kovács, 1992). 
A adolescência é reconhecidamente um momento singular do processo de crescimento e desenvolvimento, no qual ocorrem mudanças significativas na relação do sujeito com seu corpo e com seus laços amorosos e sociais, as quais são vividas diferentemente, dependendo do contexto em que se insere o jovem (Outeiral, 2003).

Frente a essas transformações - físicas, psíquicas, sociais -, o adolescente precisa deixar para trás seu mundo infantil e viver o luto dessa perda, voltando-se inicialmente para si mesmo, rompendo com ideais e valores familiares e sociais vigentes, para poder se diferenciar e adotar novos modelos, na busca de sua identidade (Osório, 1989).

Essa não é uma tarefa simples, pois impõe intensas transformações e, eventualmente, um mal-estar, causado por um corpo que se modifica e é estranho, ou mesmo um luto pelo corpo perdido, ao lado da quebra dos ideais infantis e da separação dos pais, fatores que concorrem para que o adolescente passe por uma série de dificuldades nas situações peculiares a essa etapa da vida.

Evidentemente, se o adolescente, já sobrecarregado por tantas demandas, tem também que lidar com a perda de uma pessoa significativa, muito provavelmente se configurará uma situação tal que lhe exigirá um esforço de elaboração ainda maior e que poderá esgotar suas estruturas defensivas e precipitar respostas extremas (Domingos; Maluf, 2003).

Sabe que, na adolescência, a perda parental pode comprometer a aquisição da independência e da autonomia adulta, podendo levar o jovem a regredir a uma condição menos amadurecida - que é um dos maiores problemas que o adolescente pode enfrentar -, embora também, como qualquer crise, possibilite ao sujeito fazer uso de soluções criativas que promovam seu amadurecimento (Pereira, 2004; Domingos; Maluf, 2003; Balk, 2000; Domingos, 2000).

Nesse sentido, as dificuldades a que o adolescente deve fazer face podem ser acentuadas, principalmente quando ele não encontra condições para falar sobre suas experiências de perda, ficando impedido de esclarecer dúvidas ou de expressar seus sentimentos relativos ao luto, ou quando não pode contar com o respaldo de seu meio social no sentido de ser compreendido, de ter sua dor legitimada ou de contar com um genitor sobrevivente funcional, que o faça sentir-se cuidado, amparado e seguro.

Portanto, a experiência de luto pela morte de mãe e/ou pai na adolescência é um fator de risco para a saúde mental, e, na literatura, tem sido relacionada à depressão, à presença de doenças graves, a intensos e perturbadores sentimentos de culpa, à redução da auto-estima e ao desenvolvimento de distúrbios psíquicos, prejudicando a performance escolar e 
profissional e nos relacionamentos interpessoais e estimulando comportamentos desviantes (Pereira, 2004; Domingos; Maluf, 20003; Domingos 2000).

O luto precoce aumenta a suscetibilidade do indivíduo à dificuldade escolar, à depressão e à delinqüência, e algumas das conseqüências possíveis do luto prolongado referem-se a prejuízos na saúde, ao favorecimento de distúrbios mentais como transtornos depressivos, distúrbios da intimidade e da identidade, problemas com a lei e dificuldades na paternidade ou na maternidade (Balk, 2000; Nader, 2000).

Assim, o estudo do processo de luto em adolescentes que perderam o pai biológico por morte pode ampliar a compreensão de como esse grupo vivencia esse processo, associando os desafios e transições dessa fase do desenvolvimento com as experiências e resultados desse luto, detectando fatores de risco e vulnerabilidades que interfiram em seu enfrentamento.

Finalmente, pretende-se também, através deste estudo, promover a reflexão sobre a necessidade de se proporem atuações que favoreçam aos adolescentes a vivência de um processo de luto no qual a perda sofrida possa ser ressignificada, e seus danos, minimizados. 


\section{OBJETIVOS}

\section{I.1 OBJETIVO GERAL}

Este estudo tem por objetivo investigar a vivência do processo de luto em adolescentes pela perda do pai biológico por morte de qualquer natureza.

\section{I.2 OBJETIVOS ESPECÍFICOS}

A partir do objetivo geral, delinearam-se objetivos específicos a serem investigados junto aos adolescentes que participaram deste estudo:

- as vivências e manifestações relacionadas às suas experiências de perda e luto pela morte do pai biológico;

- as repercussões dessa perda para eles e para seu desenvolvimento emocional;

- as estratégias de que se valeram para o enfrentamento dessa perda;

- a resiliência frente à perda vivida (entendida aqui como a capacidade do jovem de resistir às adversidades geradas pela morte do pai, adaptar-se à nova situação e manter-se psicologicamente saudável, cumprindo suas tarefas cotidianas), identificando-se fatores de risco (vulnerabilidades) e fatores de proteção (apoio) que tenham dificultado ou favorecido a elaboração desse luto e comprometido ou não o desenvolvimento desses jovens;

- a eventual necessidade de se proporem formas de cuidado específicas para os enlutados, que abarcam inúmeras possibilidades terapêuticas, ainda que profiláticas, em relação à vivência desse luto: aconselhamento - diferente da psicoterapia e recomendado em outros casos -, e apoio social, que pode ser obtido na própria comunidade, mesmo que informalmente, e em grupos de auto-ajuda.

\section{I.3. HIPÓTESES}

Considerando-se os objetivos específicos, estipulou-se que se investigariam as seguintes hipóteses:

- a vivencia do processo de luto pela morte do pai biológico entre o final da adolescência média e o início da tardia apresenta características próprias, 
distinguindo-se do luto que essa perda acarreta em outras fases do ciclo vital, em função dos desafios singulares do desenvolvimento por que passam os adolescentes durante esse período;

- a morte do pai biológico pode representar para o adolescente uma crise e, ao mesmo tempo, uma oportunidade para que ele busque soluções criativas, que lhe favoreçam não só o enfrentamento dessa perda, mas também seu amadurecimento;

- se, na elaboração de seu luto, o adolescente órfão de pai tiver suporte social de uma rede de apoio que compreenda e atenda suas necessidades, isso provavelmente concorrerá para que ele supere essa perda;

- a dificuldade do adolescente em se expressar quanto à morte de seu pai biológico, mesmo que ela se tenha dado anos antes, pode levá-lo a ficar entorpecido e a negar as conseqüências dessa perda, comprometendo seu desenvolvimento emocional. 


\section{MÉTODO}

Propõe-se aqui uma pesquisa qualitativa, surgida no desenvolvimento das investigações nas ciências humanas, quando era preciso superar os limites das análises meramente quantitativas (Pádua, 2000).

A pesquisa qualitativa preocupa-se com o significado dos fenômenos e processos, levando em conta as motivações, crenças, valores e representações sociais que permeiam a rede de relações sociais, aspectos que não são passíveis de mensuração e controle em moldes estritamente estatísticos.

Nesse sentido, Martins e Bicudo (1998) sublinharam a importância de se estabelecer o conceito de fenômeno, objeto da pesquisa qualitativa e que pode ser entendido como aquilo que se manifesta, o que se mostra, ou seja, o que é visível em si mesmo e que pode se revelar de várias formas, dependendo do acesso que se tem a ele.

Dessa forma, na pesquisa qualitativa em Psicologia, um fenômeno se apresenta em local determinado, ou seja, só pode ser entendido em função da situação específica em que acontece e se mostra. Por exemplo, o ciúme, a depressão, a hostilidade, o medo etc. só se podem considerar fenômenos em situações concretas nas quais alguém sinta ciúme, depressão etc., e o acesso a eles se dá, mais especificamente, pelo sentimento e, indiretamente, pela descrição desse sentimento.

Conseqüentemente, a pesquisa qualitativa abandona a generalização e focaliza o específico, buscando uma compreensão particular daquilo que se estuda, através de descrições individuais e interpretações subjetivas das experiências vividas, "como um modo de ajuizar o sentido das proposições que levam a uma compreensão ou aclaramento dos sentidos e significados da palavra, das sentenças e dos textos" (Martins; Bicudo, 1988, p. 28).

Assim, o pesquisador e sua relação com o sujeito pesquisado é elemento fundamental na pesquisa qualitativa em Psicologia Clínica, e se colocam para o pesquisador inúmeras questões sobre os aspectos subjetivos intrínsecos a essa relação.

$\mathrm{Na}$ pesquisa qualitativa, o pesquisado "não representa uma entidade objetiva, homogeneizada pelo tipo de resposta que deve dar, mas é reconhecido em sua singularidade como responsável pela qualidade de sua expressão, relacionada com a qualidade de seu vínculo com o pesquisador" (Rey, 2002, p. 57).

Portanto, nessa situação, apesar do norte dado pela teoria, o pesquisador é um dos principais instrumentos da pesquisa no tratamento dos dados, posto que é a ele que compete captar e interpretar as sutilezas do fenômeno estudado, atribuindo-lhe significados. Em 
síntese, na pesquisa qualitativa, o pesquisador não é mero observador, mas um instrumento essencial, pois participa ativamente da investigação.

Assim, para que o pesquisador conduza adequadamente seu estudo, ele deve estar consciente de seus vieses cultural, étnico, racial e de gênero, para identificar sua eventual interferência na análise dos dados. Essa modalidade de pesquisa exige grande severidade na objetivação, na originalidade, na coerência e na consistência das idéias.

Ressalte-se, no entanto, que a opção por uma metodologia depende também da natureza do objeto de estudo, dos objetivos da pesquisa e do enquadramento teórico que orientará a análise dos dados.

Neste caso, a metodologia qualitativa pareceu a mais indicada, pois, em função do objeto e dos objetivos, é a que permite uma maior compreensão da singularidade humana frente ao luto, ou a procura de significados das ações e das relações humanas nesse contexto, que não podem ser captados por equações, médias ou cálculos estatísticos.

Neste caso, a investigação partiu de relatos de jovens de 16 a 18 anos que perderam o pai entre o quarto ano de vida e há mais de um ano do início deste estudo, de modo que tomou como fonte de dados o ambiente natural e o pesquisador, como seu principal instrumento; deu prioridade aos dados descritivos e ao significado que os sujeitos pesquisados atribuíram a seus sentimentos, às coisas e à sua própria vida, de modo que a análise dos dados valorizou mais o processo do que os resultados obtidos (Trivinos, 1992).

Para se compreender o processo de luto dos jovens que participaram deste estudo, adotou-se como principal referencial teórico a teoria do apego, de Bowlby (2002), embora contribuições de outros autores que pesquisam o luto - sobretudo o de adolescentes (Doka, 2000; Franco, 2000; Parkes, 1998; Corr e Balk, 2001; Worden, 1996, 1998, entre outros) também tenham sido consideradas, sempre da perspectiva de que cada indivíduo vivencia seu luto de forma singular.

Entretanto, apesar de se ter enfatizado a abordagem qualitativa, ela é complementada com alguns dados quantitativos, apostando-se na fecundidade dessa articulação. Enquanto aquela permite que se investigue a fundo o fenômeno do luto, esta dá mais precisão a alguns de seus aspectos (Silva, 1998; Minayo, 1994), e assim se justifica o uso do Youth Self Report (YSR), um inventário de auto-avaliação para jovens, com que se levantou o perfil psicológico dos adolescentes que participaram deste estudo.

Fundamentado em medidas e em suas relações, de forma rigorosa e sistemática, para atingir precisão, validade e confiabilidade, esse inventário permitiu generalizações de medidas que contribuíram para enriquecer a análise qualitativa das entrevistas. 


\section{II.1 PARTICIPANTES}

Participaram desta pesquisa cinco adolescentes de 16 a 18 anos, de ambos os sexos, de classe socioeconômica média-baixa, órfãos de pais policiais, cuja morte ocorreu entre seu quarto ano de vida e há mais de um ano do início deste estudo. Em todos os casos, os pais tinham sido casados legalmente e viviam juntos na ocasião da morte do pai, cujas causas variaram entre assassinato, acidente automobilístico e doença crônica.

Embora a Organização Mundial de Saúde (OMS, 2008) estabeleça a adolescência entre 10 e 20 anos, só ouvimos jovens de 16 a 18 anos, para tentar trabalhar com características mais homogêneas e com sujeitos menos vulneráveis aos eventuais riscos que este estudo acarreta. Além disso, consideraram-se os limites do YSR (Achenbach, 1991; 2007), que rastreia problemas de saúde mental em adolescentes de 11 a 18 anos.

Ainda para proteger os adolescentes de possíveis riscos pela participação neste estudo, determinou-se que a perda do pai se deveria ter dado há pelo menos um ano, excluindo-se os jovens que pudessem estar numa condição mais vulnerável.

Por outro lado, para poder compartilhar sua experiência de perda e de luto pelo pai, considerou-se que seria mais próprio que, por ocasião dessa morte, o filho já tivesse condições cognitivas de compreender minimamente o que se passava, daí que se tenha estipulado o quarto ano de vida, idade a partir da qual ele já poderia guardar alguma lembrança do pai e de seu falecimento.

Assim, o tempo decorrido entre a morte do pai do adolescente e sua participação nesta pesquisa variou de 4 a 15 anos, o que não é um problema, pois sabe-se que o processo de luto pode durar de meses a anos (Worden, 1998) ou mesmo não findar (Rangel, 2005).

Para se reduzirem os riscos da participação de adolescentes com problemas de saúde mental, o convite foi feito a jovens que atendiam aos critérios descritos e eram alunos de uma escola de ensino médio da cidade onde vivia a pesquisadora, na suposição de que, assim, atenderiam às demandas sociais esperadas de indivíduos de sua faixa etária, de modo que, pelo menos em princípio, esse critério excluiria jovens com dificuldades mentais mais acentuadas.

Tomou-se ainda o cuidado de só se convidar o adolescente depois da anuência de seu responsável, e logo no primeiro contato com cada um deles foram esclarecidos o objetivo e as condições desta pesquisa. Cumpre notar que todos os responsáveis e jovens que foram convidados mostraram disponibilidade quase imediata em colaborar, explicitando por escrito 
sua concordância com os termos desta investigação, ao assinarem um Termo de Consentimento Pós-esclarecido (Anexo I).

Por fim, para assegurar o anonimato dos participantes, cada um dos adolescentes é identificado aqui pela letra inicial de seu nome de batismo.

\section{II.2 LOCAL}

Esta investigação contou com a colaboração de uma escola particular de ensino médio, de grande porte, localizada numa das capitais do sul do país, que também foi escolhida por ter entre seus principais objetivos o atendimento a órfãos de policiais, oferecendo-lhes bolsa de estudos (totais ou parciais) e acompanhamento pedagógico, quando necessário.

Após contato com a direção da escola, a pesquisadora teve a oportunidade de apresentar sua proposta ao corpo diretivo, aos psicólogos e à assistente social do colégio, que reconheceram a importância do estudo e se dispuseram a cooperar.

Antes de ser executada, a proposta foi discutida com a assistente social e com os psicólogos da escola, que sugeriram algumas mudanças nos procedimentos. Essas proposições foram integralmente acatadas e se referiam à adequação ao cotidiano da escola e dos alunos.

Inicialmente, fez-se um procedimento piloto, para que se avaliasse cada etapa, sobretudo aspectos como o tempo necessário para a aplicação do YSR, a duração da primeira entrevista e sua adequação aos objetivos da pesquisa, ente outros.

Esse piloto foi analisado e discutido pela pesquisadora, sua orientadora e a banca do exame de qualificação, que concluíram por sua aplicação tal como estava, sem qualquer mudança no procedimento proposto inicialmente.

Desde o piloto, todos os procedimentos foram executados nas dependências da escola, em salas de aula antecipadamente reservadas para isso, na quais entrevistadora e entrevistado ficaram à vontade, sem ser interrompidos e onde se pôde preservar o sigilo.

Como os participantes estudavam no período matutino - das $7 \mathrm{~h} 00$ às $12 \mathrm{~h} 30$-, todos os procedimentos tiveram lugar logo depois das aulas, conforme disponibilidade do jovem e da pesquisadora e acerto prévio entre eles.

Houve apenas duas exceções. Uma delas foi no procedimento piloto, em que o primeiro encontro com uma das adolescentes ocorreu durante a aula de Psicologia, por sugestão dos psicólogos da escola; mas, como esse tempo não foi suficiente para se concluir o procedimento, marcou-se outro encontro, às $18 \mathrm{~h} 00$, na própria escola, onde a jovem estagiava à tarde. 
A outra exceção foi porque uma jovem ia diretamente da escola para o trabalho, e a pesquisadora, psicóloga clínica, disponibilizou seu consultório particular, situado no centro da cidade e em região de fácil acesso, para com ela realizar os procedimentos deste estudo.

\section{II.3 INSTRUMENTOS}

Para a coleta de dados, utilizaram-se:

- o Youth Self Report (YSR), inventário de auto-avaliação para jovens (Achenbach, 1991, 2007);

- uma primeira entrevista psicológica, semi-estruturada, aqui entrevista inicial com o adolescente;

- uma segunda entrevista, aberta, aqui designada entrevista de retorno.

O YSR é um instrumento padronizado, internacionalmente reconhecido e utilizado para rastrear problemas de saúde mental em jovens de 11 a 18 anos. Este estudo usou a versão brasileira, traduzida para o português pelo Laboratório de Terapia Comportamental do Instituto de Psicologia da Universidade de São Paulo, sob a supervisão da Profa. Dra. Edwiges Silvares, em parceria com o Departamento de Psiquiatria e Psicologia Médica da Escola Paulista de Medicina, da Universidade Federal de São Paulo, sob a coordenação da Dra. Isabel Bordin, mediante autorização e acompanhamento do próprio autor (Anexo II).

No entanto, deve-se ressaltar que, embora um estudo preliminar indique que há uma boa correlação entre os escores médios obtidos por adolescentes encaminhados a serviços de saúde mental da amostra normativa norte-americana e os escores médios obtidos pelos adolescentes brasileiros encaminhados para atendimento psicológico, os estudos de validação da versão brasileira do YSR ainda estão em estágio embrionário.

Nesta investigação, o uso do YSR visou a permitir à pesquisadora:

- conhecer um pouco do cotidiano do jovem e ter uma noção de como ele vive sua adolescência;

- estabelecer com ele, logo de início, um contato mais próximo, que criasse uma atmosfera de maior confiança tanto para o jovem se sentir mais à vontade para falar sobre seu luto como para a pesquisadora acolhê-lo, se fosse preciso; (A pesquisadora leu e acompanhou o participante enquanto ele respondia a cada uma das questões do inventário, procedimento que, embora seja compatível com as instruções para a aplicação do instrumento, não é tão habitual, pois o YSR é em geral auto-aplicado.) 
- obter um perfil psicológico do jovem para compará-lo com os dos demais jovens de sua faixa etária, já que se trata de um instrumento padronizado. Esse perfil permite que se façam algumas considerações sobre seu desenvolvimento e, em certos casos, até mesmo que se lhe sugira um acompanhamento psicológico, quando isso parece necessário e compatível com os objetivos de sua utilização. ( $O$ encaminhamento é previsto pelo próprio manual do YSR (Achenbach, 1991, 2007).)

O YSR é um dos inventários que compõem o Sistema de Avaliação Empiricamente Baseado do Achenbach (ASEBA) (Achenbach, 1991; 2007), que representa o sistema de avaliação mais utilizado e pesquisado no mundo.

Atualmente, o ASEBA tem mais de 6.000 publicações, que relatam pesquisas em 67 culturas e estudos de validação em diversos países, tendo sido traduzido para inúmeras línguas (Rocha, 2007).

O modelo proposto pelo sistema ASEBA visa a obter dados para a avaliação de problemas e competências comportamentais e emocionais com base no comportamento observável relatado por diferentes fontes, que, assim, pode variar de acordo com o observador e o contexto.

Esse sistema inclui uma série de inventários, que se propõem a subsidiar os profissionais da área da saúde mental na avaliação de diferentes indivíduos em contextos variados, de modo que se obtenham perspectivas múltiplas sobre o funcionamento dessas pessoas, pelas pontuações que compõem diferentes perfis.

A elaboração desse sistema fundamentou-se nas experiências de profissionais que acompanharam pacientes em diferentes âmbitos e os relatos dos próprios clientes sobre sua experiência. Analisaram-se estatisticamente os dados obtidos junto a uma grande amostra, identificando-se padrões de problemas mais freqüentes, segundo pontuações atribuídas por diferentes avaliadores.

Rocha (2007) ressaltou que os padrões derivados dessas análises estatísticas possibilitaram a construção de escalas que revelaram síndromes, ou conjuntos de problemas que co-ocorrem com os clientes que foram encaminhados para serviços de saúde mental ou que obtiveram escores muito altos entre a população geral. Essas síndromes receberam nomes que descrevem os problemas a que se refere cada uma.

Vale enfatizar ainda que os escores dos itens de problemas dos inventários do sistema ASEBA, inicialmente apresentados em perfis, também podem ser fornecidos sob a forma de gráficos, expressando a situação do cliente dentro das síndromes de problemas comportamentais e emocionais. 
Desse modo, baseado em décadas de pesquisas e experiências práticas, desde os anos 1960, o sistema ASEBA:

- permite a obtenção de dados quantitativos e qualitativos;

- revela as semelhanças e diferenças de funcionamento dos clientes em diferentes contextos, em sua interação com pessoas diferentes (avaliação através de múltiplas perspectivas) e em diferentes momentos;

- facilita a comparação das informações obtidas por diferentes profissionais;

- possibilita a comparação entre os perfis dos examinandos com amostras normativas (por sexo e idade) e com suas próprias impressões;

- apresenta qualidades psicométricas satisfatórias;

- apresenta ferramentas que avaliam um grande espectro de psicopatologias;

- fornecer escalas orientadas pelo DSM-IV;

- é econômico (com relação a custos e tempo);

- permitir estudos sobre diferenças culturais em diversos países.

O YSR é um dos inventários do ASEBA para avaliação da população escolar e também uma variação de outro instrumento dessa coleção, o Child Behavior Checklist (CBCL), inventário de comportamento de crianças e adolescentes, que avalia indivíduos de 4 a 18 anos e deve ser respondido por pais ou responsáveis (Achenbach, 1991; 2007).

No YSR, avalia-se a saúde mental dos adolescentes de 11 a 18 anos por informações fornecidas pelo próprio jovem, que em cada item deve reconhecer, nos seis meses imediatamente anteriores ao preenchimento do inventário, a presença ou não de determinados comportamentos. O inventário é composto por duas partes: uma que avalia Competências e outra, Problemas. Na primeira, avaliam-se Atividades e Social, cujos resultados são expressos por escalas que levam o mesmo nome, e pode-se também obter a Competência total, através de sua respectiva escala. Na segunda parte, a somatória dos escores obtidos permite que se trace um perfil dos problemas do adolescente que é derivado da análise de oito agrupamentos de itens que compõem síndromes (subescalas ou escalas individuais):

a) Ansiedade/depressão: chorar muito; fobia simples; fobia de escola; medo de fazer ou pensar algo destrutivo; perfeccionismo; não se sentir amado; sentir-se desvalorizado; nervoso ou tenso; muito ansioso e medroso; sentir-se culpado; preocupar-se com o que acham dele; falar em suicídio; mostrar-se muito preocupado. 
b) Isolamento/depressão: anedonia (perda da sensação de prazer nos atos que costumavam proporcioná-la); preferir ficar sozinho; mostrar-se reservado; tímido; sem energia; triste; retraído.

c) Queixas somáticas: ter pesadelos, constipação intestinal; tonturas; cansaço; sentir dores inespecíficas; cefaléia; náuseas, problemas com os olhos; problemas com a pele; dores abdominais ou epigastralgia; vômitos e outras queixas do gênero.

d) Problemas sociais: revelar-se muito dependente dos adultos; queixar-se de solidão; não se relacionar bem com outras crianças e adolescentes; ter ciúme facilmente; sentir-se perseguido; machucar-se com freqüência; frequentemente ser alvo de gozações; relatar que outras crianças e adolescentes não gostam dele; mostrar-se desajeitado; preferir conviver com crianças mais jovens; ter problemas na fala.

e) Problemas de pensamento: pensamentos obsessivos; machucar-se de propósito; apresentar alucinações auditivas; tique; cutucar a própria pele; mexer em partes íntimas em público; apresentar compulsões; alucinações visuais; dormir menos que as outras crianças; revelar colecionismo; comportamentos estranhos; idéias estranhas; falar dormindo; ter problemas com o sono.

f) Problemas de atenção: comportar-se de modo infantil; não terminar o que começa; dificuldade em fixar a atenção; mostrar-se agitado; parecer confuso; perder-se nos próprios pensamentos; estar impulsivo; não apresentar um bom desempenho na escola; revelar-se desatento; distrair-se com facilidade; permanecer com o olhar parado.

g) Comportamento de quebrar-regras: usar bebida alcoólica sem permissão; não demonstrar arrependimento; desrespeitar as regras; andar em más companhias; mentir; preferir crianças e adolescentes mais velhos; fugir de casa; colocar fogo nas coisas; apresentar problemas sexuais; roubar; praticar atos de vandalismo.

h) Comportamento agressivo: discutir muito; revelar-se cruel; exigir atenção; destruir suas coisas; destruir as coisas dos outros; desobedecer em casa; desobedecer na escola; entrar em muitas brigas; atacar fisicamente as pessoas; gritar muito; irritar-se com facilidade; revelar mudanças repentinas de humor; ficar emburrado facilmente; desconfiado; gostar de "gozar da cara" dos outros; mostrar-se "esquentado"; ameaçar as pessoas; fazer muito barulho.

Rocha (2007) mostra que o YSR ainda fornece outras informações, sob o título Outros problemas, onde se incluem os itens que não são incorporados nas síndromes mas que, junto com estes, são usados para se calcular o escore de Total de problemas.

Por sua vez, algumas das síndromes foram agrupadas em duas grandes categorias, de acordo com o tipo de problemas considerado: Problemas externalizantes e Problemas 
internalizantes. No primeiro grupo, concentram-se sobretudo conflitos com outras pessoas e se incluem os sintomas das síndromes Comportamento de quebrar-regras e Comportamento agressivo. O segundo engloba principalmente problemas e conflitos internos do adolescente, que muitas vezes não são perceptíveis por outras pessoas. Este grupo é composto por sintomas das síndromes Ansiedade/depressão, Isolamento/depressão e Queixas somáticas.

A atual versão brasileira do YSR também permite que os itens de Problemas sejam apresentados em perfis que configuram as Escalas orientadas pelo DSM-IV (subescalas Problemas). Cada uma delas inclui itens que foram avaliados por especialistas como muito consistentes com as categorias daquela classificação, de modo que as obtidas a partir dessa análise são: Transtornos afetivos, Transtornos de ansiedade, Problemas somáticos, Déficit de atenção/transtorno de hiperatividade, Transtorno opositor desafiante, Transtorno de conduta, Transtorno obsessivo-compulsivo e Transtorno de estresse pós-traumático.

Além disso, ao ser transformados em escores T, os escores brutos do YSR informam se os adolescentes apresentam comportamento desviante em relação ao esperado para sua idade e sexo. A partir desses escores e com base em pontos de corte para os escores $\mathrm{T}$, a amostra pode ser classificada em três categorias: clínica, não clínica e limítrofe, podendo-se incluir esta categoria em qualquer uma das primeiras.

Assim, os resultados obtidos pelos adolescentes podem ser avaliados em clínicos, limitrofes ou não clínicos, na Escala total (Total de problemas), e, quanto aos Problemas externalizantes e internalizantes, nas oito síndromes (subescalas) aferidas pelo instrumento, bem como nas Escalas orientadas pelo DSM-IV.

Por fim, através de um relato narrativo, o YSR também fornece um resumo dos resultados e indica itens considerados críticos, que inspiram maiores cuidados, segundo o julgamento de profissionais da área clínica.

Rocha (2007) acrescenta que todos os perfis do YSR podem ser registrados e analisados a mão ou com o auxílio do computador, neste caso, através de programa próprio, o software central da ASEBA, o Assesment Data Manager (ADM).

Quanto à entrevista inicial com o adolescente, é um instrumento elaborado pela própria pesquisadora, semi-estruturado, que abordou com os participantes aspectos de sua perda e de seu processo de luto pela morte do pai, em função dos objetivos deste estudo. Essa entrevista foi o principal procedimento para a coleta de dados desta pesquisa e, juntamente com o inventário YSR, compôs o levantamento de dados propriamente dito.

A seleção dos temas e das questões dessa entrevista não se orientou apenas pelos objetivos do trabalho, mas também por uma revisão da literatura disponível, especialmente 
três estudos recentes com a população brasileira, dois dos quais com adolescentes: Fatores de risco para luto complicado numa população brasileira (Franco; Mazorra; Tinoco, 2002), Vivências de morte e luto em escolares de 13 a 18 anos (Domingos, 2000) e Adolescência, luto e enfrentamento (Pereira, 2004).

Nessa entrevista, as questões foram organizadas de modo a se abordarem primeiro aspectos mais gerais e depois os referentes à perda e ao luto, segundo uma seqüência temporal dos acontecimentos. Então, às questões que tratavam de aspectos gerais da vida do adolescente, seguiram-se outras, sobre os acontecimentos acerca da morte de seu pai, antes, na época e depois dessa perda, e, finalmente, sobre vivências e manifestações relativas a esse luto e sobre as impressões do jovem acerca de sua participação neste estudo.

Vale lembrar que, como instrumento de pesquisa, a entrevista pode ser definida como um encontro interpessoal solicitado pelo pesquisador e que visa à comunicação verbal para o levantamento de informações sobre o objeto de pesquisa (Minayo, 2000; Turato, 2003). A escolha desse instrumento foi norteada pela natureza do estudo - a entrevista tem sido considerada procedimento fundamental na investigação científica psicológica e amplamente utilizada por pesquisadores de campo da área (Bleger, 1980; Pádua, 2000; Turato, 2003). Para Pádua (2000), a entrevista em pesquisa de campo tem vantagens como a possibilidade de análise quantitativa e qualitativa dos dados e o fato de poder ser aplicada a pessoas de qualquer segmento da população.

Pela entrevista, o pesquisador pode obter dados "objetivos", relativos aos fatos, e dados subjetivos como, idéias, crenças, opiniões, pensamentos e sentimentos, atitudes, condutas, comportamentos e razões, conscientes e inconscientes, do entrevistado (Turato, 2003; Minayo, 2000). Além disso:

[...] a entrevista é um instrumento precioso de conhecimento interpessoal, facilitando, no encontro face a face, a apreensão de uma série de fenômenos, de elementos de identificação e da construção potencial do todo da pessoa do entrevistado e, de certo modo, também do entrevistador (Turato, 2003, p. 308).

Posto que o pesquisador não é neutro, distante ou emocionalmente isento, ele também participa da investigação, e é preciso considerar sua empatia, sensibilidade, humor e sinceridade como componentes importantes da pesquisa. Isso leva à necessidade de que a entrevista transcorra num ambiente de cordialidade e de aceitação mútua, que favoreça o diálogo franco (Turato, 2000), e essa mesma conjuntura impõe limites que também devem ser 
observados: a fidedignidade do entrevistado e a possibilidade de o entrevistador avaliar, julgar e interpretar as informações de forma distorcida (Minayo, 2000; Pádua, 2000).

Além disso, na relação que se estabelece entre entrevistador e entrevistado, ocorrem dois fenômenos psíquicos que participam desse encontro e determinam significativamente sua produtividade: a transferência e a contratransferência. O primeiro diz respeito à atualização, na entrevista, por parte do entrevistado, de padrões de sentimentos, atitudes e condutas inconscientes estabelecidos ao longo de seu desenvolvimento, principalmente daqueles vividos nas relações interpessoais com seus familiares na infância (Laplanche, 1994; Bleger, 1980). O segundo, por sua vez, diz respeito ao conjunto de reações do entrevistador à pessoa do entrevistado, e mais especificamente à sua transferência.

$\mathrm{Na}$ verdade, esses fenômenos se dão em toda relação interpessoal, mas, numa entrevista, se bem manejados, podem e devem ser usados como instrumentos técnicos de observação e compreensão do psiquismo do entrevistado (Laplanche, 1994; Bleger, 1980).

Deve-se ressaltar ainda que a entrevista pode seguir padrões diferentes, que podem ser resumidamente agrupados em entrevista fechada (estruturada) e a entrevista aberta (não estruturada), conforme seja mais ou menos dirigida pelo entrevistador (Minayo, 2000; Bleger, 1980).

$\mathrm{Na}$ entrevista fechada, as questões seguem um roteiro previamente elaborado, têm formulação específica e são apresentadas segundo uma ordem predeterminada, não tendo o entrevistador liberdade para alterar qualquer uma dessas disposições. Evidentemente, esse modelo tem vantagens e desvantagens. Sua padronização imprime maior agilidade ao trabalho, reduz custos, permite a inclusão de muitos participantes, facilita o tratamento dos dados e a reprodução dos procedimentos, mas há perdas quanto à amplitude das respostas e pela impossibilidade de mudar as perguntas ou pedir informações adicionais (Laville; Dionne, 1999).

Com maior flexibilidade, a entrevista aberta supõe que o entrevistado discorra livremente sobre o tema que lhe é proposto e permite, "na medida do possível, que o entrevistado configure o campo da entrevista segundo sua estrutura psicológica particular, [...] [o que] possibilita uma investigação mais ampla e profunda da personalidade" (Bleger, 1980, p. 10).

Ensejando um contato mais próximo entre o pesquisador e o entrevistado e favorecendo a exploração em profundidade da personalidade deste último, a entrevista aberta é particularmente adequada à pesquisa qualitativa (Minayo, 2000; Laville; Dionne, 1999). 
$\mathrm{Na}$ verdade, embora as entrevistas semi-estruturada e não estruturada não sejam exatamente iguais, pois diferem quanto ao grau de estruturação, nenhuma interação cuja finalidade seja a pesquisa é completamente espontânea (Minayo, 2000).

$\mathrm{Na}$ entrevista semi-estruturada, opção deste estudo, apesar de o pesquisador seguir um roteiro de perguntas, este é apenas um fio condutor e facilitador da comunicação, pois o entrevistador permite e, às vezes, até incentiva o entrevistado a falar livremente sobre temas que surjam como desdobramento do foco da pesquisa (Pádua, 2000).

Na pesquisa qualitativa, a entrevista semi-estruturada é a abordagem mais adequada e, por isso, a mais usada, pois, guiando a discussão, o entrevistador garante que ela gire em torno dos objetivos e hipóteses propostos, mas, dando certa liberdade ao entrevistado, pode obter informações mais ricas e fecundas (Minayo, 2000; Rey, 2000; Turato, 2000; Bleger, 1980).

Aqui, a escolha pela entrevista semi-estruturada permitiu que o pesquisador seguisse um roteiro de perguntas preestabelecido - em função do tema, dos objetivos e das hipóteses da investigação -, mas também que adotasse uma postura mais flexível diante do participante, levando em conta suas necessidades, seu ritmo e seu discurso. Mostrando-se mais empático ao jovem, favorecendo o estabelecimento de um clima de confiança e concorrendo para o curso da entrevista, o pesquisador também pôde ajustar a entrevista à realidade da situação, incluindo ou excluindo uma pergunta, por sua inadequação, ou pelo fato de ela já ter sido respondida, ou por ter perdido a importância, em face do discurso e da reação do entrevistado.

A flexibilidade desse instrumento permitiu que o entrevistador fizesse pausas e também expressasse sua empatia para com o relato do jovem, o acolhesse quando ele se mostrava sensibilizado por algum tema e o orientou quando pareceu necessário.

Além disso, de acordo com seu compromisso ético, o entrevistador teve a liberdade e a condição de fazer colocações que favorecessem ao adolescente a expressão de sentimentos relativos a essa perda, legitimassem sua dor pela morte do pai e o ajudassem a reconhecer que cada um tem um modo particular de vivenciar seu luto, atitudes pouco estimuladas em nossa sociedade, mas muito importantes para uma saudável elaboração do luto (Domingos, 2000; 2003).

Por fim, após cerca de dois a três meses da aplicação do YSR e da realização da entrevista inicial com o adolescente, marcou-se com cada um dos jovens um segundo encontro, a entrevista de retorno (Anexo III), cujo único objetivo era oferecer ao jovem algum tipo de suporte, caso ele precisasse e quisesse. Esta foi uma entrevista breve, aberta, em que se procurou levantar as impressões do jovem sobre sua participação na pesquisa e identificar eventuais reflexões que ele tenha feito em função dela. Além disso, se nessa entrevista, o 
jovem manifestasse demanda por uma orientação ou por um acompanhamento psicológico, ele seria encaminhado para uma clínica-escola, sem ônus algum para ele, o que, no entanto, não foi necessário em nenhum dos casos.

\section{II.4 PROCEDIMENTOS PARA COLETA E ANÁLISE DOS DADOS}

O procedimento de coleta de dados desta investigação incluiu as seguintes etapas:

\section{a) Convite}

Como já foi dito, esta pesquisa contou com a colaboração de uma reconhecida instituição de ensino médio que presta serviços a órfãos de policias, para a qual apresentei o projeto e pedi autorização para convidar alguns de seus alunos adolescentes, entre aqueles que se enquadrassem nas exigências deste estudo.

Concedida a autorização, a pesquisadora, junto com os psicólogos e a assistente social da instituição, profissionais que ficaram encarregados de auxiliá-la no que fosse preciso, considerando os critérios de inclusão, indicaram aleatoriamente alguns alunos.

Depois, por telefone, conversei com os responsáveis por esses jovens e, com sua autorização, com os próprios jovens, apresentando a pesquisa e dando a cada um deles os devidos esclarecimentos, de acordo com as normas éticas previstas pela Resolução n. 196/96, do Conselho Nacional de Saúde.

\section{b) Encontros}

Os encontros ocorreram nas dependências da escola, em salas reservadas para esse fim, sempre após o horário de aula dos participantes e em função da disponibilidade da dupla.

Com exceção do primeiro adolescente a realizar os procedimentos planejados, com quem se fizeram efetivamente três encontros, os demais participantes só estiveram duas vezes com a pesquisadora. Essa exceção se deveu ao fato de que, inicialmente, por sugestão da escola, os encontros com os jovens seriam durante as aulas de Psicologia, o que demandaria pelo menos três encontros com cada um. Mas, depois da realização do piloto, decidiu-se planejar as atividades em duas etapas, sempre após o horário das aulas, o que permitia que as entrevistas transcorressem durante o tempo que fosse preciso, sem interrupções.

Assim, na primeira etapa, em um único encontro, retomaram-se os esclarecimentos contidos no Termo de Consentimento Pós-esclarecido, aplicou-se o YSR e, depois, se realizou a entrevista inicial com o adolescente; tudo isso se cumpriu, em média, em uma hora e meia. 
Cerca de três meses após a conclusão da primeira etapa, realizou-se a entrevista de retorno.

Os responsáveis pelos jovens tiveram a liberdade de acompanhá-los aos encontros, para conhecer a pesquisadora e se esclarecer sobre o procedimento, mas nenhum deles manifestou esse desejo.

Como já se sabe, nos dois encontros, as entrevistas foram gravadas e depois transcritas, com a devida autorização do jovem e de seu responsável.

c) O inventário de auto-avaliação para jovens (YSR)

$\mathrm{Na}$ primeira entrevista, o jovem iniciou sua participação respondendo ao YSR (Achenbach, 1991, 2007), tendo sido instruído para tanto pela pesquisadora, que leu para ele cada questão, acompanhando-o durante todo o tempo em que ele se dedicou a responder o inventário.

Apesar de esse inventário poder ser respondido sem nenhuma ajuda, optou-se por assessorar o jovem para se dirimirem possíveis dúvidas que ele pudesse ter a respeito do YSR, ao mesmo tempo em que se criava uma maior proximidade com o participante.

d) Entrevista inicial com o adolescente

Logo depois de responder ao YSR, o jovem participou da entrevista inicial semiestruturada, em que se abordaram questões relativas à perda de seu pai e ao luto vivido.

Sobre as entrevistas, importa ainda destacar que foram preparadas para garantir o máximo de benefícios e o mínimo de danos que o fato de falar sobre sua perda pudesse acarretar para os jovens, a quem também se cientificou de que se depois dessa entrevista eles sentissem necessidade de conversar sobre ela, poderiam procurar a pesquisadora.

e) Entrevista de retorno

Ainda para se assegurar ao jovem o máximo de vantagens e o mínimo de prejuízos que lhe pudesse acarretar o fato de falar sobre sua perda e seu luto, o pesquisador fez com cada participante uma segunda entrevista, cerca de três meses depois da primeira.

Nessa segunda entrevista, procurou-se saber se o jovem apresentava algum tipo de dificuldade relativa à sua perda e a seu processo de luto, sobretudo pelo fato de ter participado deste estudo, de modo a se avaliar a conveniência de se propor a ele algum tipo de ajuda. Felizmente, nenhum deles fez qualquer queixa que justificasse a proposição de uma terceira 
entrevista, para apoio ou orientação, e muito menos a indicação de um acompanhamento psicológico, e tampouco revelou algum desejo nesse sentido.

Ainda assim, a pesquisadora se dispôs a lhes prestar, em qualquer tempo, mais esclarecimentos sobre aspectos da pesquisa de que participaram ou ligados à perda e ao luto que vivem, e mesmo indicar um acompanhamento psicológico gratuito.

f) Análise dos dados

Pelas especificidades dos instrumentos que se empregaram neste estudo - o YSR e a entrevista semi-estruturada -, a análise dos dados foi feita com estratégias diferentes.

Para o tratamento das respostas ao YSR, usou-se um programa de informática específico, o Assesment Data Manager (ADM).

O ADM é o software central do ASEBA, e sua versão de 2007 foi gentilmente disponibilizada pelo Laboratório de Terapia Comportamental do Instituto de Psicologia da Universidade de São Paulo.

Os resultados desse tratamento forneceram inúmeras informações de natureza qualitativa e quantitativa sobre o perfil psicológico dos adolescentes pesquisados, normatizadas por idade e sexo.

Já a análise do conteúdo das entrevistas teve como referência a abordagem sugerida por Bardin (1970), contemplando a categorização e a descrição do material obtido, bem como a proposição de inferências que as características do discurso permitiam, cumprindo-se em três etapas:

a) Transcrição: as entrevistas foram transcritas de modo a recuperar tanto quanto possível os acontecimentos dos encontros, e o material obtido foi organizado em protocolos.

b) Pré-análise: consistiu na leitura flutuante do material obtido, ou seja, uma leitura exaustiva das transcrições das entrevistas, em que a pesquisadora se deixou impregnar pelas impressões e pelos discursos, atentando para todos os elementos que os compunham, sua construção, retórica, tonalidade emocional, silêncios, lapsos, etc.

Depois de se esgotar o contato com as entrevistas já transcritas, discriminaram-se conteúdos de naturezas diferentes, estabelecendo-se categorias objetivas e temáticas relacionadas com a pesquisa, seus propósitos e sua fundamentação teórica.

A grande maioria dessas categorias já havia sido considerada anteriormente, por ocasião da elaboração da entrevista, de modo que poucas foram as inclusões nessa etapa.

Para esclarecer esse procedimento, apresenta-se a lista final com a qual efetivamente se trabalhou, sinalizando as inserções que se deram após o exame exaustivo das transcrições, 
informando que o item "Outras repercussões", inicialmente proposto, foi suprimido após a leitura do material.

- Dados de identificação do adolescente:

- sexo;

- escolaridade;

- idade (atual e na ocasião da morte do pai);

- contexto familiar (estruturação do núcleo familiar) antes, na ocasião e após a perda;

- relacionamento com o pai e o papel deste no contexto familiar.

- Características da perda e circunstâncias que a permearam:

- circunstâncias da morte do pai: causa e tipo de morte e tempo transcorrido desde então;

- forma como o jovem recebeu a notícia da morte do pai;

- acesso ou não a informações relativas a essa morte;

- participação do adolescente nos rituais do funeral.

- Vivências e manifestações relativas à perda e ao processo de luto do jovem (reações do participante à perda):

- imediatas;

- subseqüentes;

- atuais.

- Resiliência (competência mesmo em circunstâncias adversas) do jovem frente a sua perda, considerando-se especificamente fatores de risco (vulnerabilidade) e de proteção para luto complicado (fatores que representaram algum tipo de apoio para o jovem, favorecendo-lhe a vivencia de seu luto):

- fatores predisponentes no adolescente;

- fatores da relação com o falecido pai;

- fatores relativos à perda em si;

- suportes sociais;

- outros:

- a experiência com os rituais de luto;

- as condições socioeconômicas;

- a crença em vida após a morte;

- a expressão de vivências relativas à perda e ao processo de luto; 
- flexibilidade da estrutura familiar;

- grau de comunicação e de união entre os membros do núcleo familiar;

- presença de figuras substitutivas;

- presença de modelos de identificação;

- vitimização.

- Estratégias gerais de enfrentamento - pensamentos ou ações (intencionais e conscientes ou não) no sentido de eliminar ou reduzir a ameaça gerada pelos problemas decorrentes da morte do pai;

- Repercussões (mudanças psicossociais) da perda para o adolescente e seu desenvolvimento, no tocante a suas:

- representações atuais sobre si próprio;

- representações atuais sobre o outro (categoria que inclui possíveis influências da morte do pai no modo como o jovem estabelece ou vivencia as relações atuais);

- representações atuais sobre a vida em geral e expectativas sobre o futuro;

- estruturação familiar atual;

- outras repercussões.

- Avaliação da entrevista: procurou-se abordar aí os motivos pelos quais o jovem se dispôs a participar deste estudo e como se sentiu durante e depois da participação.

Finalizando essa etapa, destacaram-se os segmentos das entrevistas que continham informações diretamente ligadas ao estudo.

c) Análise e interpretação: descrição e discussão dos dados, levando-se em conta os aspectos recorrentes, convergentes e divergentes, procurando-se equacionar dimensões, relações, tendências e padrões para elucidar seu significado de acordo com as proposições deste estudo.

Assim, através de cuidadosa reflexão sobre os textos transcritos, a participação de cada jovem e as deduções (inferências) a que levaram as informações levantadas e à luz da teoria psicológica, atribuíram-se significados aos dados encontrados e se propuseram interpretações para esclarecer os questionamentos postos por este estudo.

Com os resultados da análise do YSR e o tratamento das entrevistas, articularam-se essas informações e suas interpretações, em função dos objetivos deste trabalho e da teoria que o fundamentou, finalizando a análise dos dados obtidos. 


\section{II.5 CONSIDERAÇÕES ÉTICAS}

Esta pesquisa se estruturou e executou de acordo com as normas éticas previstas pelos códigos nacionais, resolução n. 196/96, do Conselho Nacional de Saúde, tendo sido aprovada pela Comissão de Ética do Departamento de Psicologia Clínica da Universidade de São Paulo, em 30 de abril de 2008 .

Além disso, como participaram deste estudo pessoas de luto, foi preciso levar em conta especificidades como:

- o fato de se tratar de uma população vulnerável, o que aumenta o risco de prejuízos a que os participantes ficam sujeitos;

- a dificuldade de se avaliar a possibilidade de riscos a longo prazo, já que o luto é um processo;

- a individualidade do processo de elaboração do luto, o que dificulta as generalizações;

- a possibilidade de o enlutado não estar em condições de discernir sobre sua participação ou não;

- a necessidade de que o pesquisador estivesse devidamente preparado para lidar com essa população, fosse do ponto de vista teórico ou de sua experiência clínica.

Para se garantirem esses cuidados e se registrar formalmente a anuência dos participantes à proposta da pesquisa, apresentou-se a cada um deles e a seu responsável um termo de consentimento, que ambos assinaram e os informava:

- da natureza da pesquisa, seus objetivos e procedimentos (inclusive a gravação e a transcrição das entrevistas pela pesquisadora);

- de que se tomariam todos os cuidados para se evitarem os danos previsíveis, iniciativa que incluiu: a) cuidados com a abordagem do tema na entrevista e suas possíveis conseqüências; b) uma entrevista de acompanhamento com o jovem, três meses depois do procedimento propriamente dito; c) a possibilidade de uma entrevista adicional, em qualquer tempo, se o jovem tivesse necessidade ou interesse; d) o compromisso de que, mesmo depois de a pesquisa ter sido concluída, o jovem e sua família teriam o devido respaldo, com orientação e, se necessário, encaminhamento do adolescente e/ou do responsável para atendimento especializado gratuito, em clínica-escola, onde se averiguou a viabilidade de o atendimento se dar quase que prontamente; 
- da preservação do anonimato do sujeito e da garantia do sigilo e da confidencialidade dos dados, que seriam usados apenas com fins acadêmicos e mantidos sob a responsabilidade da pesquisadora, após o término da pesquisa;

- do compromisso da pesquisadora em respeitar os valores culturais, sociais, morais, religiosos e éticos, bem como os hábitos e costumes dos sujeitos;

- de seu direito de se recusarem a participar ou de retirarem seu consentimento a qualquer momento. 


\section{A MORTE E O LUTO}

\section{III.1 O HOMEM OCIDENTAL E A MORTE}

Embora seja um fato natural do ciclo vital, a morte - fim da existência humana, única certeza absoluta da vida - evoca no homem ocidental contemporâneo intensa angústia e muito medo (Rangel, 2005; Oliveira, 2001; Bromberg, 2000; Domingos, 2000; Kovács, 1992; Kubler; Ross, 1989).

Nos dias de hoje, porém, de acordo com Rangel (2005), convive-se com a morte de diversas formas, entre duas situações extremas: a morte interdita e a morte escancarada.

No caso da morte interdita, a morte é vivida como um tabu e, ou se evita falar sobre ela, ou se fala dela com eufemismos, para negá-la, de modo que, em geral, ao ocorrer em hospitais e asilos, ela se mantém distante do dia-a-dia da maioria das pessoas.

Por outro lado, mortes trágicas, catastróficas ou violentas têm sua divulgação favorecida pelos recentes avanços tecnológicos, sendo veiculadas escancaradamente e de forma sensacionalista pela mídia, que praticamente obriga as pessoas a conviverem com elas. Assim, passam a ser assunto corriqueiro e recorrente, o que talvez até possa, em parte, representar também uma tentativa de elaboração do impacto que essas mortes acabam tendo. Essa é a morte escancarada.

No entanto, nem sempre foi assim. Embora, diante da morte e de seu luto, o homem ocidental da atualidade ainda mantenha atitudes oriundas de antigos costumes, ao longo da história, essas atitudes passaram por mudanças profundas e estabeleceram uma ruptura histórica com relação às condutas anteriores (Maranhão, 1998).

O historiador francês Philippe Ariès (1977) se dedicou a reconstruir historicamente as atitudes e representações do homem ocidental diante da morte e do luto, desde a Idade Média até a Idade Moderna, descrevendo as diferentes realidades que encontrou ao longo dos tempos. Em sua obra $O$ homem perante a morte, o autor procurou sistematizar essas realidades de acordo com a prevalência de determinados significados atribuídos pelo homem à morte. No entanto, segundo Kovács (1992), deve-se ressaltar que, apesar de as representações abordadas por Ariès (1977) serem mais características de um ou de outro período ou momento histórico, elas podem estar presentes em outros momentos. 
O primeiro desses significados prevaleceu por volta dos séculos IX e X, na Idade Média, período que Ariès (1977) chamou de a morte domada, quando o homem tinha com a morte uma convivência mais próxima e natural.

Nesse contexto, as pessoas comumente sabiam que iam morrer ou esperavam pela morte em casa, cercadas por seus familiares, vizinhos e até mesmo pelas crianças, depois de terem se preparado antecipadamente para isso, inclusive ditando suas últimas vontades.

A morte era, portanto, uma cerimônia pública, anunciada, de modo que, embora fosse temida, era aceita e esperada como uma lei da natureza, da qual não se poderia fugir. $\mathrm{O}$ grande receio era morrer repentinamente, sem os rituais de preparação, o funeral e o sepultamento.

Ariès (1977) salienta também que, na época medieval, os sentimentos de dor pelos mortos podiam ser expressos mais livremente, já que os rituais fúnebres favoreciam a vivência do luto, permitindo um contato mais direto com a morte e as manifestações de dor admitidas nesses rituais.

Entretanto, o homem medieval temia o contato com os mortos porque acreditava que eles podiam contaminá-lo fisicamente, através da decomposição dos corpos, ou psiquicamente, com a assombração de fantasmas ou almas penadas, de sorte que muitos dos rituais fúnebres praticados na época visavam a facilitar aos mortos sua jornada para os céus, separando-os definitivamente dos vivos.

Ainda na Idade Média, a partir dos séculos XI e XII, o homem passou a se inquietar com o que aconteceria após sua morte, com sua ida para o inferno ou para o paraíso. Assim, preocupado com o juízo final - a avaliação que Deus faria das almas - e com o que the aconteceria no exato momento de sua morte, o homem mudou sua relação com a morte, e ela já não era mais encarada com a mesma naturalidade de antes. Para Ariès (1977), nesse período, a morte pode ser entendida como a morte em si mesmo (ou a morte de si mesmo).

Aí, a hora da morte assumiu uma grande importância, como a hora da "passagem da alma", e a principal preocupação era realizar essa passagem com a garantia do perdão divino e, conseqüentemente, com um lugar reservado no paraíso (Oliveira, 2001).

Como, na época, o apego aos bens materiais se tornara o grande pecado, os meios preconizados para se alcançar a absolvição eram os donativos feitos à Igreja, as orações aos mortos, a compra das indulgências e do perdão da Igreja, pois se acreditava que era preciso se desfazer dos bens materiais para ir para o céu.

Desse modo, pela necessidade de se terem garantias de como seria o juízo final, os testamentos dessa época representavam não só um ato de direito privado, destinado a regular a transmissão dos bens, mas sobretudo, um ato religioso, no qual o fiel professava sua fé, 
reconhecia seus pecados e resgatava-os por um ato público, além de doar parte de seus bens à Igreja, como garantia de sua salvação, e prescrever seus desejos quanto a seu funeral (Ariès, 1977).

Também nesse período o corpo morto passou a receber um tratamento diferente, sendo encerrado em caixões, excluído e escondido, pois os vivos não precisavam ver os mortos agora, uma visão insuportável. Nesse contexto, intensificou-se a técnica do embalsamamento, numa tentativa de se conservar viva a imagem do morto, o que também pode ser entendido como uma de se negar a ocorrência da morte (Oliveira, 2001).

Nesse âmbito, os temas macabros se tornaram freqüentes e revelavam as fantasias e os temores que se haviam instalado frente ao morto e à morte, o que só veio a perder um pouco de sua importância - e gradativamente - depois do século XVI.

Então, sob a influência do idealismo, o sofrimento trazido pela morte passa a não ser mais tão relacionado à agonia dessa hora, e sim à tristeza do rompimento de uma amizade, concepção que suprime o caráter concreto da morte, representado pelo moribundo agonizando no leito, e lhe atribui um sentido metafísico, expresso pela metáfora da separação da alma e do corpo.

Paralelamente, do fim da Idade Média até o século XVIII, os rituais de luto englobavam uma série de procedimentos e atitudes de forma a induzir a família do morto a manifestar, por certo tempo, dor e tristeza pelo ente querido, sentimentos nem sempre sinceros. Essas manifestações de pesar tinham ainda a função de proteger os sobreviventes da dor pela morte do familiar, mas assumiram proporções que fizeram com que o luto passasse a ser ostentado e as expressões de pesar se tornassem mais controladas e austeras (Dias, 1991).

Segundo Ariès (1997), o que não se podia expressar por palavras ou gestos passou a ser representado pelo uso da cor preta - e de outras - por parte dos enlutados, o que assumia vários significados: o medo que se tinha dos mortos, o abandono e a perda sofrida, sugerindo a necessidade de uma atenção especial para com os enlutados.

Outro ritual que ganhou força nesse período foi a celebração de missas - inúmeras -, que começavam antes da hora da morte, missas de intercessão, outras, no próprio momento da morte ou imediatamente depois dela, mas que duravam dias, semanas, meses, um ano; algumas ligadas aos rituais do funeral, na época denominado serviço, outras, não.

Além disso, começou-se a acreditar que o cadáver conservava certa sensibilidade, um resíduo de vida, de modo que se poderia constituir em matéria-prima para medicamentos para 
a prevenção e a cura de doenças, ser usado na fertilização da terra e compor poções com poderes afrodisíacos ou capazes de transmitir vida a moribundos (Kovács, 1992).

Em função dessas crenças, ganhou força a concepção de que a alma era imortal, e ficou difícil separar o natural do sobrenatural e a vida da morte. As pessoas passaram a ter medo de serem enterradas ainda vivas, e surgiram vários rituais para atrasar os enterros, como os velórios: a morte estava distante e próxima, e a ênfase recaía sobre a vida na morte (Kovács, 1992).

Porém, a partir do século XVIII e até a metade do século XIX, sob a influência do romantismo, a morte ganhou novo e diferente sentido, passando a representar um sublime descanso e a oportunidade de se reencontrar o ser amado. Nesse contexto, a morte é percebida como arrebatadora e impressionante e deixa de ser temida para ser amada e desejada; prevalece a crença na vida após a morte, e já se começa a defender a possibilidade de comunicação entre vivos e mortos e da reencarnação (Dias, 1991; Kovács, 1992).

Ainda segundo Kovács (1992), contraditoriamente, o medo que predominava nesse período era relativo às almas do outro mundo, que poderiam vir perturbar os vivos, o que deu origem a uma série de rituais que tinham por objetivo afugentar esses seres.

Nessa época, o homem se ocupava menos de sua própria morte, e mais da morte do outro. Mudou até mesmo a concepção de como deveriam ser os cemitérios, com novas leis que instituíram padrões para o sepultamento dos mortos, estabelecendo-se regras quanto ao espaço e à profundidade das covas.

Desse modo, no século XIX, o luto adquiriu uma expressão ainda mais contundente, pois, diante do morto, os sobreviventes tendiam a se comover excessivamente, o que revela que a morte não era mais percebida como um evento tão natural, mas cada vez mais de difícil aceitação, indomesticável, selvagem (Domingos, 2000).

Já no século XX, houve mudanças significativas na atitude do homem ocidental diante da morte e em sua vivência de luto em algumas das regiões mais industrializadas e urbanizadas, mais tecnicamente avançadas, e a sociedade passa a expulsar a morte de seu âmbito, afetando que nada aconteceu, de modo que a morte pública, como um evento que atingia toda a sociedade, passou a conviver com a morte vergonhosa (Ariès, 1977).

A partir do século XIX, com os avanços da medicina, já se podia ter conhecimento da proximidade da morte, e ela passou a assustar tanto, que se fazia de tudo para não se falar nela e se negar sua iminência. Incapazes de tolerar sua morte, os que estavam à volta do moribundo temiam contar-lhe a gravidade de seu estado e tudo faziam para ocultá-la. 
Assim, o moribundo passou a não ser mais dono de si, mas sua família é que se responsabilizava por ele. De acordo com Ariès (1977), essa morte, caracterizada pela alienação do próprio moribundo de sua condição, é a morte invertida.

Nesse período, com a medicalização da sociedade, fundada no triunfo sobre a doença e a morte, esta passou de um acontecimento natural a um evento que representava o fracasso, a impotência e a imperícia, devendo por isso ser ocultado. A presença da morte não deveria ser percebida, e a boa morte ocorreria quando o moribundo fingia que não sabia que iria morrer e não se sabia se a pessoa tinha morrido ou não (Oliveira, 2001; Kovács, 1992).

Se não havia morte, não havia luto, de modo que a expressão aberta da dor, de sentimentos e de emoções suscitadas pela perda da pessoa que morreu passou a ser considerada mórbida e de mau gosto, tornando-se proibida; muitas vezes, só restava ao sobrevivente chorar às escondidas, num luto solitário, como se fosse vergonhoso demonstrar pesar pela perda de uma pessoa querida.

Com o tempo, e principalmente no século XX, entre 1930 e 1950, com a transferência do local da morte do lar para o hospital, a mudança de postura diante da doença e da morte que era defendida com o argumento de representar um avanço tecnológico, e essas tendências se fortaleceram e consolidaram (Domingos, 2000).

Entretanto, essa mudança de postura também era, de certa forma, conveniente para o hospital e para a família. Para o hospital, afastava-se a família do doente com a justificativa de que ela embaraçaria o bom andamento do hospital e do trabalho dos médicos, com suas lamentações, choros ou questionamentos e rituais (Aires, 1977). Além disso, como os pacientes terminais também incomodam os profissionais de saúde com sua revolta, sua dor, seus questionamentos e exigências, a função de se responsabilizar pelo moribundo passou a ser do hospital e da equipe médica, que assim teria como controlar tais inconvenientes.

Por outro lado, a família se preservava da convivência com aspectos considerados repugnantes e mórbidos da doença e da morte, além de poder mais facilmente escamotear sua dor e seu luto, cujas expressões importunariam a sociedade, por serem consideradas de mau gosto, vergonhosas e muitas vezes associadas a manifestações histéricas (Domingos, 2000).

Dessa forma, não só o moribundo seria poupado, mas também sua família, os vizinhos e a sociedade, sobretudo as crianças, que, diante da morte, poderiam ficar traumatizadas. Assim se excluíram a morte e o luto da sociedade ocidental, situação que ainda é bastante comum na atualidade, pois, numa sociedade voltada para o progresso e para a produtividade, a morte e o luto devem ser mantidos ocultos, sem direito a um espaço público, para não 
causarem constrangimento e para que a sociedade não se tenha que ocupar com o limite e a finitude.

Antes, o enlutado se entristecia e tinha liberdade e acesso a rituais para dar livre vazão a sua dor, ser confortado pela presença e pelo amparo de pessoas próximas, que traziam freqüentemente lembranças do morto; hoje, até se pode considerar que o enlutado tenha o direito de sofrer, mas privadamente, poupando os demais da sua dor.

Além disso, o amparo de pessoas próximas muitas vezes the é negado, pois as pessoas evitam se aproximar dele, por considerarem que essa seria uma atitude indiscreta ou invasiva ou por não suportarem, não terem o devido preparo para conviver com a dor e o pesar do outro (Domingos, 2000; Oliveira, 2001).

Nesse contexto, a morte mais bem vista passou a ser por doença ou velhice, sem ser abrupta, para poder ser mais bem digerida por parentes e amigos (Dias, 1991), embora, da perspectiva de quem morre, a morte mais desejável seja a morte súbita, sem tempo para se dar conta dela e, conseqüentemente, para sofrer (Kovács, 1992).

Mas, a partir de 1960, surgiram novas mudanças, com o início de um movimento que procurava resgatar a participação do homem em sua morte, tornando-o mais consciente desse processo. A precursora desse movimento foi Elizabeth Kubler-Ross, que, em 1965, participou de um projeto de pesquisa para investigar as crises da existência humana, tendo a morte como seu principal objeto de pesquisa (Oliveira, 2001; Kovács, 1992).

A partir de então, vários outros estudiosos têm se ocupado de estudar o tema da morte e procurado inseri-lo no cotidiano, com o intuito de humanizá-lo e recuperar seu sentido como parte integrante e significativa da vida do homem.

No campo da saúde, entre psicólogos, terapeutas e médicos, observa-se um interesse pela humanização da morte e pelo respeito aos moribundos, o que tem ensejado mudanças significativas na postura de muitos profissionais de saúde diante da morte e no manejo de pacientes terminais.

Assim, a representação atual do homem sobre a morte e o morrer, sobretudo na sociedade ocidental - cada vez mais globalizada, dominada pela tecnologia e pela internet, mas em que convivem lado a lado realidades tão díspares -, também é marcada pela diversidade e por sua história, embora nenhuma discussão sobre o luto possa desconsiderar a idéia da morte interdita, ainda tão presente e tão bem identificada por Ariès (1977). 


\section{III.2 O LUTO}

\section{III.2.1 Apego, perda e luto}

A palavra "luto" origina-se do vocábulo lugere, que em latim significa "chorar", e dá nome a uma vivência decorrente do rompimento de um vínculo significativo cuja ausência deixa um vazio e causa intenso sofrimento, demandando uma adaptação (Rangel, 2005; Pereira, 2004; Bromberg, 2000).

O estudo desse tema começou a despertar o interesse dos pesquisadores a partir das experiências de perdas em massa das duas grandes guerras, até meados do século XX, mais precisamente, a partir da década de 1940. Desde então, vem crescendo o número de pesquisas e trabalhos que, sob diferentes perspectivas, se têm desenvolvido e publicado com o intuito de se ampliar a compreensão desse evento e de suas repercussões (Rangel, 2005; Franco, 2002a).

A princípio, a ênfase desses estudos recaía sobre as repercussões emocionais e fisiológicas do luto, e, como se entendia que a condição estabelecida pelo conjunto de emoções que acompanham o luto se assemelhava a uma doença, a concepção inicial do luto foi marcada por um caráter patológico. Em função disso, aspectos do luto ligados ao social foram por algum tempo preteridos e mesmo ignorados (Franco, 2002a).

A percepção do luto como uma doença com sintomas facilmente identificáveis favoreceu não só que profissionais da saúde passassem a adotar esse ponto de vista, mas também se disseminasse entre os leigos a idéia de que o luto era uma doença e que se tinha que fazer de tudo pela cura do enlutado.

Com o tempo, ganharam espaço outras concepções, a partir de outros modelos teóricos que também procuravam descrever e explicar o processo de luto, mas que o entendiam com uma resposta natural diante de uma perda significativa.

Entre esses autores, destaca-se John Bowlby (2002), com sua teoria biológica do luto, que defende uma concepção funcional do luto, entendido como um conjunto de reações pertinentes ao rompimento de um vínculo significativo.

As idéias de Bowlby (2002) influenciaram muitos outros reconhecidos autores da área, como o psiquiatra inglês Colin Murray Parkes (1972), que trata o luto como uma resposta a uma situação de estresse e, no Brasil, a pesquisadora brasileira, Maria Helena Pereira Franco (2000), com inúmeros trabalhos acerca do tema.

Ultimamente, soma-se a essas proposições a ponderação de que as pessoas apresentam resultados diferentes em seus processos de luto também porque esses resultados refletem 
variadas representações sociais sobre a morte e o morrer e, por isso, são transitórios ou sensíveis à cultura. Além disso, a possibilidade da apreciação da relatividade cultural da própria emoção, bem como a inclusão da espiritualidade como aspecto significativo para a compreensão do fenômeno de luto, entre outros, contribuíram para promover mudanças nas concepções sobre esse processo.

Neste estudo, como já foi dito, optou-se por uma abordagem clínica do luto, que enfatiza o processo de formação e rompimento de vínculos e encontra respaldo sobretudo na teoria do apego, desenvolvida pelo psiquiatra britânico John Bowlby (2002), o primeiro e um dos mais importantes pesquisadores a estudar a tendência do homem a estabelecer fortes laços afetivos com o outro (Bowlby, 2002).

Fundamentado em suas pesquisas, ele formulou uma teoria de vinculação que procura explicar o apego e as reações emocionais que ocorrem quando os laços afetivos ficam ameaçados ou se rompem, dando uma interpretação funcional do luto (Bowlby, 2002; Oliveira, 2001; Worden, 1998).

A partir de aspectos psicológicos e biológicos, Bowlby (2002) considerou que o comportamento de vinculação (apego) consiste num conjunto integrado de sistemas comportamentais presente em filhotes de quase todas as espécies de mamíferos e cujo objetivo é garantir a sobrevivência do indivíduo, ao visar à obtenção de segurança e proteção pessoal (Abreu, 2005).

Segundo a teoria do apego formulada por Bowlby (2002), os laços afetivos entre humanos surgem muito cedo na vida, ao longo de quatro etapas, e tendem a perdurar por uma grande parte do ciclo vital, de modo que a criação de vínculos com pessoas significativas é uma conduta própria não só em crianças, mas também em adultos.

Para Bowlby (2002), logo ao nascer, o bebê responde aos estímulos do ambiente, indiscriminadamente, orientando-se, agarrando-se, sorrindo e balbuciando, que são também os modos pelos quais ele provoca comportamentos de aproximação nas pessoas que cuidam dele. Nesse período, que dura cerca de dez semanas, embora o bebê responda de forma generalizada a todos os estímulos que recebe do ambiente, ele revela preferências pelo rosto e pelas vozes humanas.

$\mathrm{Na}$ etapa seguinte, o bebê já consegue dirigir-se à mãe ou a seu cuidador principal e reconhece uma série de ruídos.

Em torno do sexto ou sétimo mês de vida, o bebê elege uma figura de apego, que passa a ser discriminada das demais, e inicia-se o vínculo propriamente dito. Ou seja, o bebê passa a ter a mãe ou seu principal cuidador como referência: segue-a(o) quando ela(e) se afasta, 
saúda-a(o) quando se aproxima e tem-na(o) como base para suas explorações. Nessa fase, a criança é capaz de se manter próxima de sua figura de apego pela locomoção ou por meio de sinais que têm por objetivo o atendimento de suas solicitações.

Desse modo, apesar de o apego ser um processo entre o bebê e seus cuidadores que se inicia com o nascimento, seu desenvolvimento só se torna perceptível por volta do sexto ou sétimo mês de vida, quando o bebê começa a manifestar medo de estranhos e medo de se separar (ansiedade de separação) da mãe ou de seu principal cuidador, quando ela(e) sai de perto dele.

A quarta fase começa por volta do terceiro ano de vida e caracteriza-se pelo estabelecimento de uma "parceria" entre bebê e mãe (ou cuidador principal), de modo que ambos orientam sua conduta para um objetivo comum, pois o bebê já é capaz de intuir os sentimentos e as expectativas da mãe, as metas estabelecidas e os planos para atingi-las. Nessa etapa, quando a mãe ou a figura de apego fica indisponível, o bebê reage com intensa ansiedade e forte protesto emocional e inicia uma busca ativa pelo cuidador. Contudo, ele já adquiriu o princípio de permanência, o que lhe dá condições de ficar algumas horas longe de sua mãe ou de seu cuidador principal, apesar de seus protestos e de estranhar outras pessoas.

Nesse momento, o vínculo está construído, o que significa que pode se consolidar uma base segura para o desenvolvimento de um relacionamento mútuo que seja uma referência e um incentivo para que a pessoa explore o mundo e estabeleça um modelo representacional de si mesma como capaz de ajudar e também merecedora de ajuda.

Assim, segundo Bowlby (2002), a qualidade do vínculo primariamente construído será a base para a natureza dos vínculos futuros, além de influenciar sobremodo a visão que o indivíduo tem de si e sua condição para enfrentar e elaborar os rompimentos e as perdas que experimentará ao longo da vida.

No entanto, o tipo de vinculação que se estabelece entre a criança e seu cuidador, bem como o desenvolvimento desse laço dependem de quanta segurança a criança pode extrair da relação com seu cuidador, da sensibilidade desse cuidador para ser continente às respostas da criança e, conseqüentemente, à intensidade e à qualidade do laço afetivo (Abreu, 2005).

Ainsworth e colaboradores (1978, citado por Bowlby, 2002) estudaram as diferenças individuais do apego entre crianças pequenas e suas mães e identificaram naquelas três padrões básicos, em resposta à separação e ao reencontro com as mães: seguro, inseguro/evitador e ansioso/ambivalente.

O padrão de apego seguro inclui crianças sociáveis, que exploram ativamente o ambiente e vêem a figura de apego como alguém disponível, responsivo e que as ajuda nas 
situações adversas. Isso decorre do fato de essas crianças desenvolverem vínculos afetivos com seus cuidadores de modo a percebê-los como uma base segura a partir da qual elas podem explorar o mundo, pois se sentem protegidas e cuidadas.

Desse modo, nas creches, na ausência da mãe (ou do cuidador principal), essas crianças tendem a ser cooperativas, populares e mais capazes do que as demais.

As crianças com padrão de apego inseguro/evitador são aquelas que, quando não obtêm êxito na procura do cuidador, ficam tristes ou deprimidas e, quando ele volta, o evitam. Essas crianças ignoram e evitam a interação com a mãe, procuram se distrair com outras coisas como brinquedos e acabam por tratar muito mais amigavelmente um estranho do que a própria mãe; não raro, adotam comportamentos hostis, paradoxalmente, esperando conseguir atenção.

Para se defender da incerteza quanto ao apoio do cuidador se precisarem, elas adotam uma aparente independência emocional, mas sistematicamente vivenciam "ansiedades de separação" e assim permanecem por longos períodos "atreladas" a outras pessoas.

Em geral, esse padrão de interação é marcado por uma postura ambivalente dos cuidadores, que se mostram disponíveis em algumas ocasiões e em outras, não. A impressão de que serão rejeitadas faz com que essas crianças restrinjam a procura de apoio às situações de necessidade, e não é incomum que elas tenham sofrido ameaças de abandono, por parte dos pais, como meio de controle comportamental.

O padrão de apego ansioso/ambivalente inclui crianças com um repertório comportamental exploratório pobre, pela dificuldade de se isolarem para explorar o ambiente, já que precisam sempre de contato e têm medo de situações e pessoas diferentes.

No contato, elas se mostram ambivalentes, pois oscilam entre a busca de proximidade e a relutância à interação com o cuidador. Na verdade, essas crianças se comportam de modo extremamente ansioso, demonstrando hipersensibilidade e freqüentemente exibindo afetos negativos e vulnerabilidade em situações ameaçadoras.

Sabe-se que, embora essas crianças não tenham sido cuidadas de forma ininterrupta, essa rejeição não foi necessariamente total, mas pode ter sido parcial e intermitente, o que mantém sua expectativa de serem acolhidas e amadas, mas também as deixa angustiadas pelo medo de serem abandonadas. Por sua vez, esse medo aumenta suas exigências afetivas, o que faz com que elas se recusem a ficar sozinhas e protestem veementemente quando isso ocorre.

Em função dos constantes descuidos vividos, prevalece nessas crianças a disposição para a auto-suficiência emocional, já que não há nenhuma confiança em que sejam ajudadas, pois a crença prevalente é a de que, por terem sido rejeitadas, não serão acolhidas. 
Posteriormente, Main e Solomon (1986), citados por Abreu (2005), sugeriram a existência de um outro padrão de apego, o apego desorganizado, estilo das crianças às quais não se pode atribuir nenhum dos tipos mencionados de vinculação, mas uma versão mais desorganizada - ou desorientada - de algum deles.

Supõe-se que esse tipo de vinculação esteja relacionado à presença de uma inversão de papéis, ou seja, em vez de os pais oferecerem contato e conforto para a criança, eles esperam que o filho lhes proporcione essas condições. Em geral, essa inversão de papéis ocorre quando os pais estão consumidos pelo luto de alguma figura significativa da infância ou por algum trauma associado aos relacionamentos de vinculação que envolva abuso sexual ou físico.

Ainda em relação aos tipos de apego, vale ressaltar que, na primeira fase do desenvolvimento de sua teoria, Bowlby (2002) acreditava que o padrão de apego estaria totalmente definido na idade pré-escolar e que só se poderiam dar mudanças em seu estilo nos primeiros anos de vida. Posteriormente, com o avanço das pesquisas sobre o tema, o autor passou a defender que o padrão de apego está em permanente construção e é passível de mudança o tempo todo. Em outras palavras, não se devem tomar os padrões primários de vinculação como prognósticos certos e indiscutíveis dos relacionamentos futuros, mas sim considerar que, dependendo de acontecimentos posteriores, o padrão de apego inicialmente assumido poderá persistir e estabelecer-se de forma mais definitiva.

No entanto, observa-se que as tendências dos padrões relacionais - não só na díade criança-cuidador, mas em quase toda a família - costumam se perpetuar, posto que as relações se estabelecem complementarmente, segundo um modelo de ação e reação, o que concorre para a reprodução dos modelos relacionais vigentes pelas gerações seguintes (Abreu, 2005).

Se o objetivo do comportamento de apego é manter laços afetivos, tudo o que compromete a manutenção desse laço dá origem a determinadas reações, que a princípio visam a preservar o vínculo, de modo que, quanto maior for o risco de perda, mais intensas serão as reações (Bowlby, 2002).

Essas reações podem advir de ansiedade, tristeza ou raiva gerada pela ameaça de perda, de modo que, quando se obtém sucesso na restauração do vínculo e este se mantém, cessam as ações devidas à ansiedade e ao estresse diante do risco de rompimento do vínculo.

Contudo, esse processo pode ser reativado, na medida em que a ameaça de perda se mantém, o que provoca, talvez a intervalos cada vez mais longos, a reativação dos esforços para o restabelecimento do laço afetivo, de forma que o pesar e a urgência de se reativar o 
vínculo são vividos novamente. Se, com o tempo, o perigo não for eliminado, surgirão reações de afastamento e sentimentos de apatia e desespero.

Assim, no caso da perda da figura de apego, deixa de existir uma base segura para o indivíduo se refugiar nas situações de perigo, experiência que gera terror e medo, o que explica por que o sofrimento é uma reação universal à perda de um afigura de apego.

A partir dessas proposições, pode-se compreender por que a morte de uma pessoa significativa, que implica a perda não desejada de alguém com quem o enlutado tinha um vínculo, provoca respostas que podem ser tidas como automáticas e instintivas.

Como, da perspectiva da evolução e da necessidade de sobrevivência, a perda irreparável não existe, as reações frente a essa perda são organizadas com o intuito de restabelecer o vínculo com o objeto perdido. Essas reações compõem o processo de luto.

A partir desse ponto de vista, o luto não é entendido como uma doença, um sintoma ou uma síndrome, mas como parte do repertório comportamental desenvolvido pelo enlutado em seu relacionamento com seus cuidadores na infância.

Essa concepção explica o protesto inicial do enlutado frente à perda do objeto amado, o desespero e a desorganização diante da compreensão de que essa perda é irreversível e a necessidade de fazer tentativas irracionais de manutenção do vínculo, mesmo desconsiderando a realidade.

Visto desse modo, o luto representa uma resposta genérica à ruptura do vínculo, uma forma de ansiedade de separação que tem valor funcional na preservação da espécie, e Bowlby (2002) consegue formular explicações para a experiência de alguém que perde uma pessoa significativa.

\section{III.2.2 O processo de luto}

Assim, para Bowlby (2002), o processo de luto engloba duas mudanças psicológicas reconhecer e aceitar a realidade e experimentar e lidar com as emoções e os problemas decorrentes dessa perda -, que consomem tempo e que dependem de inúmeras varáveis que podem favorecê-las ou comprometê-las.

O trabalho do luto faz supor um teste de realidade que constata que o objeto não está mais disponível e, pela aceitação dessa realidade, o indivíduo pode desistir dessa relação e dirigir seus investimentos para outras relações afetivas, reorganizando-se, em termos emocionais, depois do vínculo que se rompeu e dar seguimento a sua vida. 
$\mathrm{Na}$ tentativa de sistematizar as reações que se podem dar ao longo desse processo, a partir de levantamento realizado por Stroebe e Stroebe (1987), Bromberg (2000) arrolou e descreveu os sintomas mais observados em enlutados, considerando aspectos afetivos e cognitivos, manifestações comportamentais e atitudes do enlutado em relação a si, ao falecido e ao ambiente, mudanças fisiológicas e queixas somáticas.

Worden (1998) ponderou que, pelo fato de haver uma extensa lista de reações de luto consideradas normais, elas poderiam ser agrupadas em quatro categorias: sentimentos, sensações física, cognições e comportamentos.

A partir das listas e as descrições organizadas por Bromberg (1998) e Worden (1998), elaborou-se o esquema que segue.

a) Reações afetivas

- Tristeza: sentimento freqüente entre os enlutados, manifesta-se em geral pelo choro, mas não necessariamente.

- Depressão: sentimento de tristeza, depressão e disforia acompanhado por intenso sofrimento subjetivo e dor mental. Episódios de depressão podem ser intensos e, algumas vezes, precipitados por eventos externos (receber carinho de alguém, ir a certos lugares, ter lembranças de coisas que se fazia junto com a pessoa falecida, aniversários etc.). Nessa categoria, predominam sentimentos de desespero, lamentação e pena, e Kovács (1992) ressalta que se pode detectar uma depressão reativa, mas também um quadro mais sério, até mesmo patológico. De modo geral, esse agravamento implica um quadro de depressão clínica (melancolia), situação na qual o enlutado apresentaria, além dos sintomas típicos do luto, um rebaixamento da auto-estima acompanhado por auto-recriminação e uma expectativa de punição. Nesse sentido, em seu artigo "Luto e melancolia", Freud (1917) foi o primeiro a examinar essas duas condições e entender que elas têm semelhanças como falta de interesse no meio externo, a perda da capacidade de amar e a inibição de atividade. Na melancolia, identifica-se o rebaixamento da auto-estima, situação na qual o enlutado não consegue ver claramente o que foi perdido, mas a presença de reações de maior gravidade indica que o processo de luto se complicou, o que será examinado mais cuidadosamente adiante.

- Ansiedade: pode variar de uma leve sensação de insegurança a um forte ataque de pânico, categoria em que se incluem medos, ameaças, sensação de impotência, de perder a cabeça, de morrer ou de ser incapaz de sobreviver sem a pessoa amada, ansiedade de separação, medo de viver sozinho, preocupações financeiras e com outros assuntos que antes eram resolvidos pela pessoa que se foi. Quanto mais forte e persistente for a ansiedade, maior 
será o risco de um luto complicado. Para Worden (1998), a ansiedade do enlutado provém sobretudo do fato de o enlutado temer não ser capaz de cuidar sozinho de si, mas também de uma sensação amplificada da consciência da própria mortalidade.

- Culpa e auto-recriminação: auto-acusações em relação a eventos do passado, notadamente àqueles que levaram a pessoa querida à morte; o enlutado sente que poderia ter feito algo a mais para evitar que a pessoa tivesse morrido. Além disso, também se observam sentimentos de culpa relativos ao modo como o enlutado tratava a pessoa que faleceu, que, na concepção do sobrevivente, deveria ter sido mais bem tratada. Em geral, esses sentimentos são irracionais e não sobrevivem ao tempo ou ao teste de realidade.

- Raiva e hostilidade: a raiva é um dos sentimentos mais confusos para os enlutados e pode dar origem a uma série de complicações para o luto. Por conta de sua raiva, o enlutado se irrita com a família e os amigos (por sentir que não entendem sua dor ou que não gostavam tanto assim do morto) e também fica com raiva do destino e do fato de a morte ter ocorrido. Além disso, o que fica mais complicado para o enlutado é perceber que sente raiva do próprio falecido. Segundo Worden (1998), essa raiva se deve a um sentimento de frustração porque não havia nada que a pessoa pudesse ter feito para evitar a morte, mas também a um movimento regressivo que acomete o enlutado, que gera uma vivência de abandono e desamparo. Em geral, essa raiva, originariamente dirigida contra o falecido, se desloca e orienta contra outras pessoas, que são então responsabilizadas pela morte da pessoa amada. Exemplo disso é a raiva que o sobrevivente sente por médicos e enfermeiros, que, na sua concepção, não fizeram tudo o que poderiam ter feito pelo falecido. Outra modalidade inadequada dessa raiva é a retroflexão, em que, além de dirigi-la contra outros, a pessoa enlutada volta sua raiva contra si mesma. Essa forma é extremamente perigosa, pois, num enlutado deprimido, pode gerar uma conduta suicida.

- Falta de prazer: perda do prazer com a alimentação, através de hobbies, em eventos sociais, familiares ou com outras atividades que antes davam prazer ao enlutado, mesmo que o falecido não estivesse presente. Sensação de que nada mais será prazeroso sem o morto.

- Solidão: é comum o enlutado sentir-se só, mesmo na presença de outras pessoas, ou viver crises periódicas de intensa solidão, sobretudo nos momentos em que o falecido estaria com ele e durante eventos que seriam compartilhados por ambos. Esse sentimento é particularmente observado quando o enlutado e o falecido conviviam cotidianamente.

- Alívio: muitas pessoas sentem alívio depois da perda de uma pessoa amada que sofria de doença prolongada ou dolorosa, mas essa sensação é comumente acompanhada por 
um sentimento de culpa. Este pode ser associado à emancipação que se verifica na medida em que o falecido - ou seu estado - impusesse alguma restrição ao sobrevivente.

- Torpor: algumas pessoas relatam ausência de sentimentos, após uma perda, ficando estarrecidas ou sendo tomadas por um torpor, o que a princípio pode representar uma reação defensiva saudável frente a uma dor insuportável, esmagadora. Assim, logo depois da perda, essa reação não demanda maiores preocupações, mas indica um mau prognóstico quando se torna uma condição permanente.

- Choque: reação comum em caso de morte súbita, embora não necessária.

- Fadiga: expressa muitas vezes pela apatia ou pela indiferença, essa experiência pode ser entendida do ponto de vista afetivo, mas também repercute na redução do nível de atividade do enlutado após a perda, tornando lenta sua fala, pela desaceleração do pensamento.

b) Manifestações comportamentais

- Agitação: tensão, inquietação atípica, hiperatividade, dificuldade de completar tarefas (ou fazer o mínimo para se manter ativo) ou adotar comportamentos que revelam o anseio de procurar o falecido, mesmo sabendo que é inútil, inclui o intenso desejo da presença do outro.

- Choro: lágrimas, olhos marejados e expressão geral de tristeza, com os cantos da boca caídos e o olhar triste.

- Suspiros: podem ser correlacionados à sensação física de falta de ar.

c) Atitudes em relação a si, ao falecido e ao ambiente

- Baixa auto-estima: sentimentos de inadequação, fracasso e incompetência nas próprias possibilidades, na falta da pessoa amada; sentimento de que nada vale a pena.

- Isolamento social: querer afastar-se das pessoas em geral é comum quando se passou por uma perda, e muitas vezes esse desejo inclui o desinteresse pelo mundo externo.

- Dificuldades e relacionamento social: o enlutado pode apresentar dificuldades para manter relacionamentos interpessoais, rejeitar amizades e distanciar-se de funções sociais, além de muitas vezes desconfiar da motivação dos que lhe oferecem ajuda.

- Atitudes em relação ao falecido: o enlutado pode sentir ondas de saudade do falecido, imitar seu comportamento (por exemplo, na maneira de falar ou de andar) ou adotar os seus interesses e objetivos. Também é muito comum o sobrevivente idealizar o morto, ignorando seus defeitos e ampliando suas virtudes. $\mathrm{O}$ enlutado pode ainda demonstrar ambivalência quanto ao falecido, alternando sentimentos de naturezas diferentes. Além disso, pode se 
preocupar exageradamente com suas lembranças, querer visitar lugares ou carregar objetos que lhe lembrem o morto, ter necessidade de falar dele exaustivamente, sem interesse por outros assuntos, ou, ao contrário, querer evitar todas essas coisas.

d) Fenômenos cognitivos

- Descrença: comumente, é a primeira reação da pessoa que perde um ente querido, especialmente quando a morte é inesperada, súbita.

- Dificuldade de atenção e concentração: inibição da memória e distrações (comportamentos “aéreos").

- Confusão mental: muitas pessoas enlutadas se queixam de não conseguir pensar ordenadamente, esquecendo-se de coisas e sentindo dificuldade para se concentrar.

- Alucinações: alguns enlutados têm alucinações, visuais ou auditivas - em geral, transitórias - e que ocorrem logo após a perda.

- Sensação de presença: essa sensação é a correspondente cognitiva da experiência de anseio e ocorre logo após a perda.

e) Mudanças fisiológicas e queixas somáticas

- Distúrbios alimentares: quando têm alterações de apetite, as pessoas enlutadas tendem a comer menos, mas algumas passam a comer excessivamente. Em função disso, também podem ocorrer alterações de peso.

- Distúrbios do sono: as alterações do sono podem englobar dificuldade para conciliar o sono, despertar precoce ou sono excessivo. O enlutado freqüentemente sonha com o morto, tanto sonhos bons como pesadelos. Esses sonhos podem dar indícios de como está se desenvolvendo o processo de luto.

- Queixas somáticas: o enlutado pode ter uma série de queixas de ordem somática como dores de cabeça, na nuca e nas costas, câimbras e falta de força muscular, nó na garganta, boca seca ou com gosto amargo, azia, náuseas, vômitos, digestão difícil, flatulência, sensação de estômago vazio e prisão de ventre, dor ao urinar, visão embaraçada, tremores, respiração curta e falta de ar, palpitações, aperto no peito, queda de cabelos, hipersensibilidade a barulho, sensação de despersonalização (por exemplo, caminhar pela rua e nada the parecer real) e falta de energia.

- Mudanças na ingestão: intensificação do uso de psicotrópicos, bebidas alcoólicas ou fumo. 
- Suscetibilidade a doenças: sabe-se que os enlutados vivem uma situação de estresse intenso, o que favorece a queda de imunidade e a falta de cuidados com a própria saúde. Assim, eles podem ficar mais vulneráveis a problemas cardíacos e a infecções.

Todas essas reações são pertinentes ao luto, mas nem todas acontecem necessariamente com todas as pessoas enlutadas ou durante todo o processo, já que cada pessoa é única e vive o luto a sua maneira (Bromberg, 2000; Franco, 2002a).

No entanto, apesar dessas diferenças, estudiosos da área (Bowlby, 1907/2002; Bromberg, 2000; Parkes, 1998) entendem que, em geral, há uma certa consistência nesses processos, que sempre envolvem uma sucessão de quadros clínicos que se mesclam e se substituem uns aos outros.

Assim, na visão desses autores (Bowlby, 1907/2002; Bromberg, 2000; Parkes, 1998), as reações que compõem o processo de luto constituem fases, que não têm uma seqüência ou uma duração previsível, mas podem ser descritas com algum grau de exatidão.

a) Entorpecimento (ou choque): um certo torpor frente à notícia da perda. Essa fase pode durar de horas a semanas e pode ser permeada por manifestações de desespero ou raiva. A pessoa recentemente enlutada se sente atordoada, desamparada, imobilizada, perdida. Há indícios de que nessa fase haja sintomas somáticos como respiração acompanhada por suspiros, rigidez no pescoço e sensação de vazio no estomago.

b) Anseio e protesto: fase de emoções fortes, com muito sofrimento psicológico e agitação física. No entanto, na medida em que a consciência da perda vai se instalando, vem o anseio por reencontrar a pessoa morta, e o enlutado vive crises de choro e de profunda dor. Embora a pessoa enlutada saiba que a perda é irreversível, às vezes é incontrolável o desejo ou a necessidade de buscar a pessoa perdida. Inclusive, há momentos em que o enlutado tem a sensação da presença do morto ou atenta para qualquer indício de que ele vai voltar. Segundo Parkes (1998), raramente a pessoa enlutada admite ou se dá conta de que visa a reencontrar o morto, mas usa esse mecanismo para abrandar a dor do luto. Também não é raro que o enlutado tenha raiva de si mesmo, por não ter cuidado do morto como deveria, se sinta culpado por sua morte e dirija sua raiva a outras pessoas, sobretudo aquelas que procuram consolá-lo, ou ao próprio morto, que o "abandonou”. Nessa fase, o enlutado vive sua perda de modo ambivalente, pois depara com a realidade da perda e todos os sentimentos que a acompanham, inclusive a esperança do reencontro. Isso pode durar de meses a anos. 
c) Desorganização e desespero: com o passar do tempo, o enlutado tende a deixar de procurar pela pessoa perdida e a assumir a irreversibilidade de sua perda. Essa é uma fase muito mais difícil do que as anteriores; ele experimenta desesperança e descrédito frente à vida e questiona se vale a pena viver sem o outro, pois tem a sensação de que nada vale a pena, nada tem valor. Nessa etapa, é muito comum que o enlutado se afaste das pessoas, cesse suas atividades e não consiga se interessar por envolvimentos de qualquer espécie. Nessas condições, o enlutado também tem dificuldade de se concentrar em tarefas rotineiras ou para iniciar atividades. São freqüentes os sintomas somáticos como a insônia, a perda de apetite e de peso, além de distúrbios gastrintestinais.

d) Recuperação e restituição: a depressão e a desesperança aos poucos começam a ceder e a conviver com sentimentos mais positivos e menos destrutivos. A pessoa enlutada começa a aceitar a perda e as mudanças dela decorrentes e consegue lidar com elas de modo mais eficiente. Com isso, desiste da idéia de recuperar a pessoa morta e começa a assumir a necessidade de começar uma nova vida. Decorrente disso, o enlutado retoma a possibilidade de fazer novos investimentos, apesar de ainda sentir certa instabilidade, pois a saudade e a necessidade da presença do outro às vezes voltam, juntamente com a tristeza. Nessa fase, mesmo quando o processo de recuperação avança, há a recorrência de sintomas que já haviam desaparecido, particularmente em datas que ativam lembranças do falecido.

A noção de fases também pode ser útil para os profissionais, no caso de intervenções, como um norte para a compreensão e a aceitação do que se passa, e para os enlutados, na busca de sentido para sua experiência de luto. Evidentemente, desde que não se normatize esse processo e se definam maneiras melhores ou piores para se viver o luto (Franco, 2002a).

A consideração de como os enlutados podem reagir a uma perda significativa também implica o reconhecimento de alguns parâmetros importantes para o curso do processo de luto e que contribuem para a compreensão dessa experiência. Esses fatores referem-se (Rangel, 2005; Franco; Mazorra; Tinoco, 2002; Parkes, 1998; Worden, 1998):

- ao enlutado: sua estrutura psíquica, seu gênero, a natureza de sua relação com a pessoa falecida, seu histórico anterior de perdas e seu contexto sociocultural (crenças culturais, religiosas, rituais de luto, estigmas etc.);

- à pessoa que morreu: quem era essa pessoa, como era sua personalidade e que papéis exercia em relação ao enlutado;

- às circunstancias da morte; 
- à presença ou não de mudanças, crises e privações concomitantes à experiência do luto.

Além disso, sabe-se que o fato de o enlutado poder contar com um ambiente acolhedor e empático para a expressão de conteúdos relativos à sua perda concorre para que ele se sinta compreendido e aceito e para que seu pesar seja reconhecido e legitimado, o que também favorece a vivência saudável do processo de luto.

Segundo Domingos (2000), as pessoas enlutadas freqüentemente se queixam de indiferença e mesmo de hostilidade das pessoas com quem convivem para com seus sentimentos e emoções decorrentes do luto, e o autor sugere que talvez essas atitudes se devam ao medo que as pessoas sentem de ser contaminadas pela dor da perda do enlutado.

Assim, o enlutado pode se sentir pressionado a voltar a suas atividades cotidianas e a deixar seu luto prematuramente para trás, de modo que, ou vive sua experiência isoladamente, ou a abandona antes de completá-la, reprimindo seus sentimentos decorrentes do luto, encorajado a ter auto-controle e a ser forte por parentes e amigos que acreditam que essa seja a melhor estratégia (Franco, 2000a).

Entretanto, ao escamotear ou fugir do luto, o enlutado corre o risco de ficar ansioso, deprimido, confuso e experimentar sentimentos de inadequação e culpa que, além de impedílo de assumir posturas e atitudes que contribuam para a elaboração de sua perda, podem conduzi-lo a adotar formas de expressão compensatórias, destrutivas ou patológicas (Domingos; Maluf, 2003).

A partir dessas considerações, conclui-se que a manifestação de sentimentos e emoções relativos à perda é uma das condições que favorece a resolução do luto, e, analogamente, reprimir tais sentimentos pode dificultar a conclusão desse processo ou mesmo torná-lo patológico (Domingos, 2000).

Finalmente, como aqui se propõe a compreensão do processo de luto em adolescentes, este também deve ser entendido no âmbito do núcleo familiar, o que implica a necessidade de se considerarem ainda fatores que influenciam o impacto de uma morte e a natureza e a duração da resposta de uma família.

Nesse sentido, Walsh e McGoldrick (1998) levantaram uma série de varáveis relativas à forma da morte, ao funcionamento do sistema familiar e social, ao momento da perda no ciclo vital e ao contexto sociocultural que, quando presentes, devem ser cuidadosamente examinadas:

- morte repentina ou prolongada; 
- ambigüidade acerca de uma perda: essa condição envolve situações em que o membro da família está ausente fisicamente mas psicologicamente presente, como em casos de seqüestro, desaparecimento de dissidentes políticos ou de soldados em ação, bem como situações em que o ente querido está fisicamente presente mas ausente psicologicamente, como no mal de Alzheimer;

- morte violenta, especialmente suicídio;

- falta de coesão para o apoio mútuo da rede familiar, indiferenciação de seus membros ou falta de tolerância a diferentes respostas;

- falta de flexibilidade do grupo familiar;

- comunicação bloqueada, presença de segredos, mitos e tabus em torno da morte;

- falta de recursos familiares, através da ausência da família extensa e/ou da inexistência ou precariedade de recursos sociais e econômicos;

- importância do papel do membro familiar perdido para o funcionamento da família, com substituições irrefletidas ou incapacidade de reinvestimento;

- reações conflituosas ou rompidas por ocasião da morte;

- perda prematura;

- perdas múltiplas ou presença de outros fatores estressores concomitantes à perda;

- legado multigeracional de perdas não resolvidas;

- sistema de crenças da família suscitando culpa ou vergonha pela morte havida;

- contexto social e político e histórico da morte, invocando a negação, o estigma ou temores catastróficos.

Todos esses fatores serão retomados em seguida, a partir da reflexão sobre as variáveis que podem comprometer a resolução do processo de luto. No entanto, embora concorra para a compreensão desse processo e, do ponto de vista didático, seja de extrema utilidade, não se deve esquecer que uma abordagem do luto pela consideração desses fatores não deve excluir a experiência do luto do âmbito da subjetividade (Franco, 2002a).

\section{III.2.3 O luto complicado}

Ninguém está imune às experiências de perda e de luto, de modo que, pela intensidade dessas vivências, do grande número de pessoas afetadas por elas e das variações sistemáticas de suas conseqüências nas diferentes populações, suas implicações têm um longo e extenso alcance na vida de qualquer pessoa (Franco; Mazorra; Tinoco, 2002). 
Algumas pessoas, depois de viver uma perda significativa, demonstram grande dor e sofrimento, que parece não se modificar com a passagem do tempo, exibindo uma consternação crônica (Rangel, 2005).

Outras, após a perda de uma pessoa amada, podem se desestruturar e desenvolver sérios distúrbios afetivos como depressão e outros transtornos psíquicos ou físicos, denunciando dificuldades ou mesmo impedimentos para elaborar seu luto (Parkes, 1998).

E há aquelas para as quais o luto decorre de uma situação traumática, em que a morte se dá de forma inesperada, súbita e violenta. Nessas circunstâncias, há um grande impacto para a identidade e a capacidade de enfrentamento do enlutado, de modo que pode se instalar uma condição de estresse permanente, que dificultará sua adaptação à nova situação, o que, para alguns autores, configura um luto traumático (Gregio, 2005).

Dessa forma, discriminar o luto normal do atípico envolve algumas dificuldades, pois são muitas e muito complexas as variáveis que compõem o processo de luto, além da semelhança que ele pode ter com outros quadros, especialmente o de depressão (Bromberg, 2000).

Além disso, como já foi dito, a tendência mais atual é se conceber o luto como uma experiência particular, já que cada pessoa é única, assim como os vínculos que estabelece e o modo como lida com a perda de uma pessoa amada, o que sugere a necessidade de concepções de luto normal e atípico pautadas também pela subjetividade (Franco, 2002a).

De modo geral, o luto complicado tem sido freqüentemente definido em função de um conjunto de reações a uma perda significativa que foge ao já descrito como característico do luto normal, no tocante à sintomatologia e ao processo, o que envolve natureza, intensidade e duração das reações, além da estruturação do processo em si (Bromberg, 2000).

Nessas circunstâncias, pode-se dizer que não responde a todas as necessidades do enlutado o processo de luto em que se dão complicações que comprometem suas possibilidades de fazer novos investimentos na vida, postergando sua readaptação ao mundo e impedindo a finalização exitosa do luto (Rangel, 2005).

Rangel (2005) salienta ainda que a delimitação do que se considera um luto anormal inclui questões sobre a terminologia com que se designa essa condição, a descrição, a intensidade e o curso dos sentimentos e comportamentos implicados no processo de enlutamento, a existência de fatores que interferem nesse processo, direcionando-o, além da controvertida discussão sobre o tempo necessário para a resolução de uma perda significativa (Rangel, 2005). 
Quanto à terminologia, constata-se, na literatura, o uso de vários termos para nomear o processo de luto "atípico": disfuncional, patológico, neurótico, desadaptativo, não resolvido, anormal, desviante, complicado, crônico, retardado, exagerado (Rangel, 2005; Worden, 1998). Essa diversidade pode dificultar o estudo do tema, na medida em que compromete a comunicação entre os pesquisadores e, conseqüentemente, a validação de consensos.

Por outro lado, mais recentemente, tem se buscado estabelecer uma tendência prevalente em torno das expressões luto complicado ou atípico, em substituição a luto patológico. Segundo Franco (2002), essa escolha procura evitar a reprodução do modelo médico e coibir uma distinção em temos de normal e anormal.

Outra dificuldade do estudo do luto complicado diz respeito ao fato de esse processo poder assumir diversas formas e, muitas vezes, faltarem critérios mais objetivos para defini-lo, porquanto se trata de um fenômeno que não é concreto, e uma reação considerada adequada em dada situação pode não sê-lo em outra (Rangel, 2005).

Freitas (2000) entende ainda que um dos aspectos mais controversos do luto é sua condição de normal ou não. Há desde vertentes que consideram patológica uma duração superior a seis meses até outras que atentam para a qualidade da dor e as funções psicológicas atingidas pelo processo de luto.

Em face de todas essas ponderações, entendem-se as dissensões entre os autores da área sobre o que seria um luto complicado.

Bowlby (2004b) considera que a vivência do luto saudável ocorre se o enlutado acaba por aceitar as mudanças do mundo externo ligadas à perda definitiva do ser amado, o que decorre da transformação dos modelos de representação interna e da reorganização da configuração dos vínculos que permaneceram, de modo que o indivíduo passa a ser capaz de pensar na pessoa que faleceu sem que isso lhe cause dor. Mas o autor entende que existem pessoas que podem apresentar algumas complicações em sua experiência de luto e exibir certas reações atípicas como o cuidado compulsivo com outras pessoas, o anseio inconsciente pela pessoa perdida associado à auto-acusação consciente, euforia e despersonalização, descrença no caráter permanente da perda e sintomas de identificação com o morto.

Portanto, para Bowlby (2004b), a exacerbação de aspectos do luto - uma duração muito longa ou características obsessivas - configura um luto complicado, e a qualidade da resposta à perda da pessoa amada sempre estará relacionada aos padrões vinculares anteriormente estabelecidos pelo enlutado.

Bromberg (2000) também defende a importância da qualidade do vínculo estabelecido antes do luto, preconizando os vínculos ansioso e vínculo seguro. O primeiro, causado por 
separações, cria relações de dependência, ao passo que o último permite o desenvolvimento da autoconfiança e da auto-estima. Para a autora, os lutos complicados mais comuns seriam o luto não-resolvido, o luto mascarado, o luto exagerado - com ansiedade exagerada -, o luto tardio, inibido, suprimido ou posposto à reação de pesar.

Posteriormente, Franco; Mazorra; Tinoco (2002) notou que, do ponto de vista clínico, a dimensão final do pesar pode ser percebida como resolução, recuperação, restabelecimento ou reorganização, mas ela propõe o termo "reconciliação", por considerar que ele expressa apropriadamente o que experimenta o enlutado quando consegue integrar sua nova realidade de estar na vida sem a presença física da pessoa que morreu, ao adquirir condições de reconhecer totalmente a realidade da morte e de se envolver novamente, com senso de confiança e energia renovados, mesmo ciente de que a dor e o pesar fazem parte da vida.

Worden (1998) entende que o luto complicado advém sempre de uma intensificação do luto que não progride em direção a seu término ou a uma adaptação frente à perda sofrida. Para o autor, quando a pessoa enlutada é capaz de pensar no morto sem dor, de reinvestir suas emoções na própria vida e de readquirir o interesse pela vida, seu luto terminou.

Worden (1998) acredita que as reações complicadas de luto podem ser nomeadas de várias formas, e que um dos paradigmas mais úteis estabelece as seguintes categorias:

a) Reações de luto crônicas: têm duração excessiva e nunca chegam a bom termo, ou seja, a pessoa não consegue retomar sua vida, condição que exige que se avalie que tarefas do luto não estão sendo realizadas e por quê.

b) Reações de luto retardadas: também chamadas inibidas, suprimidas ou postergadas, são as que, mesmo que a pessoa tenha expressado uma reação emocional por ocasião da perda, esta não foi suficiente o desenlace do processo de luto, de modo que, frente a uma perda subseqüente ou a qualquer evento ligado à perda anterior, a pessoa tem uma reação intensa e desproporcional, como se parte do luto anterior tivesse sido postergado e só pudesse ser vivido então. Em geral, essa reação postergada vem à tona para tornar-se um luto complicado.

c) Reações de luto exageradas: respostas de luto tão intensas que a pessoa enlutada fica sobrecarregada e passa a exibir uma conduta mal-adaptada, inclusive transtornos psiquiátricos maiores, que se desenvolvem depois da perda. Nesses casos, em geral, o enlutado têm consciência do que se passa com ele. São exemplos clássicos a depressão clínica, a ansiedade que se faz acompanhar por pânico ou fobias, manias, alcoolismo severo ou uso abusivo de outras substâncias que causam dependência, além de sinais que indicam a presença de transtorno de estresse pós-traumático (PTSD). 
d) Reações de luto mascaradas: são sintomas físicos ou psiquiátricos ou comportamentos mal-adaptados que prejudicam o enlutado, mas que ele não reconhece como relacionados ao luto. Nessas condições, o enlutado não expressa seus sentimentos abertamente, e o luto se manifesta por outras vias - sintomas não afetivos que representam reações de luto mascaradas. As pessoas que não se permitem viver o luto de forma direta muitas vezes desenvolvem sintomas físicos semelhantes aos que apresentava a pessoa que faleceu por ocasião de sua morte. Há indícios de que, em alguns casos, o comportamento delinqüente também pode ser entendido como um equivalente adaptativo do luto mascarado.

Já para Parkes (1965), as reações do luto complicado classificam-se em:

a) Luto crônico: prolongamento indefinido do luto, com predomínio de ansiedade, tensão, inquietação e insônia, podendo também haver sintomas de identificação.

b) Luto adiado: processo no qual a pessoa enlutada tende a adiar a reação ao luto e, por algum tempo, pode apresentar comportamento normal ou certos sintomas de luto distorcido como superatividade, sintomas da doença do morto ou isolamento. Com o tempo, esse enlutado acaba por ter depressão.

c) Luto inibido: situação em que estão ausentes os sintomas do luto, diferindo do luto adiado apenas quanto ao grau de eficácia das defesas psíquicas.

Para Sanders (1999), o luto complicado se dá quando determinados fatores resultantes de uma variedade de circunstâncias, que vão de problemas pré-mórbidos de personalidade a estresses situacionais - perturbam o curso normal do processo de luto. Esses fatores fazem com que o luto seja mais severo e duradouro do que seria de esperar ou, pelo contrário, com que o enlutado evite ou nem sequer reconheça sua dor, o que o impede de elaborá-la.

De acordo com Black (2002), para quem o pesar é a resposta normal para o processo de luto, essa resposta é caracterizada por muitos componentes que, de outra forma, poderiam ser considerados um grande episódio depressivo. Entendidos como decorrências naturais do pesar, sentimentos de tristeza, insônia, falta de apetite e perda de peso levam, em geral, à recuperação, apesar de que é preciso que o enlutado assuma uma nova identidade. No entanto, ainda segundo o autor, sentimentos como culpa, pensamentos de morte, preocupação mórbida com a falta de valor, marcante lentificação psicomotora, funcionalidade notadamente prejudicada por longo tempo e experiências alucinatórias são em geral consideradas mais típicas de uma reação patológica de pesar. 
Como reação à morte de um ente querido, o DSM-IV também reconhece que alguns enlutados podem exibir sintomas característicos de uma depressão maior, entendendo que a expressão e a duração do luto normal variam consideravelmente entre diferentes grupos culturais.

Apesar de incluir o luto no grupo de "outras condições que podem ser foco de atenção clínica", de modo a considerar essa condição, mas sem se comprometer, estipula que, se, depois de dois meses da perda, o enlutado ainda manifestar os mesmos sintomas, cabe o diagnóstico de depressão maior.

Entretanto, há certos sintomas que não são habituais de uma reação de luto normal e que podem ser úteis na distinção entre luto e depressão maior:

- culpa acerca de outras coisas que não ações que o morto tenha realizado ou não na época do falecimento;

- pensamentos sobre morte, exceto os de que deveria estar morto ou ter morrido com a pessoa falecida;

- preocupação mórbida com a inutilidade;

- retardo motor acentuado;

- experiências alucinatórias, a não ser as de ouvir a voz do morto ou vê-lo.

O CID-10 não reconhece que o luto possa suscitar psicopatologias específicas.

Horowitz e colaboradores (1997) acreditam que o luto normal pode combinar humor angustiante e pensamentos turbulentos e até confusos, mas que se pode presumir que o equilíbrio vai retornar eventualmente como resultado do processo de luto.

Entretanto, podem ocorrer situações extremas que vão prejudicar a capacidade funcional e que podem atingir um nível psicopatológico, o que tem promovido no meio médico discussões sobre a inclusão de reações de luto prolongadas e complicadas numa nosologia de transtornos mentais.

Essa necessidade se pauta na observação de que o transtorno depressivo maior não cobre adequadamente os sintomas de luto complicado, o distúrbio de ajustamento não é suficientemente específico para abarcá-lo e o transtorno de estresse pós-traumático exclui alguns sintomas comuns a ele relacionados.

Assim, Horowitz e colaboradores (1997) propõem alguns critérios para o que denominam transtorno de luto complicado, ao identificar que algumas das reações prolongadas e turbulentas do luto incluem sintomas que diferem do critério do DSM-IV para transtorno depressivo maior: 
- a experiência recorrente (mais de um ano após a morte) de pensamentos intensos intrusivos;

- rompantes de emoções severas e sentimentos de angústia;

- sentimento de intensa solidão e vazio;

- evitação excessiva das atividades remanescentes do falecido;

- distúrbios incomuns do sono;

- níveis mal-adaptados de perda de interesse em atividades pessoais.

Nesse contexto, muitos são os fatores que podem atuar como complicadores durante o processo de luto e comprometer sua resolução, sobretudo se forem ignorados ou acompanhados por sentimentos de raiva e culpa. Além disso, tanto a impossibilidade do enlutado de participar de rituais que ajudam a vivência do momento quanto a falta de apoio social para expressar sua dor constituem obstáculos adicionais para a elaboração do luto (Parkes, 1998).

Após estudos sistematizados, Parkes e Weiss (1983) identificaram os seguintes fatores preditivos de vulnerabilidade ao luto patológico:

a) Síndrome da perda inesperada: envolve a morte repentina ou prematura, apresentando reações defensivas de choque ou descrença, embora também com alto nível de ansiedade.

b) Síndrome do luto ambivalente: segue-se a uma relação que tenha sido ambivalente ou marcada por discórdia ou discussões. A reação inicial à perda é de alívio e de pouca ansiedade, mas é sucedida por desespero, indo até a desesperança relativa ao estabelecimento de outro vínculo. Persistem os sentimentos punitivos e o desejo de corrigir o passado.

c) Síndrome do luto crônico: os comportamentos do luto são imediatamente expressos e persistem por longo tempo. Ocorre depois do término de relações que se caracterizam por alta dependência. O traço característico dessa síndrome é a desesperança, e sua ocorrência independe de o sobrevivente ser o dependente ou o que mantém a dependência.

A partir das pesquisas de Stroebe e Stroebe (1987), Lundin (1984), Raphael (1983) e Maddison e Walker (1967), Bromberg (2000) agrupou os fatores de risco em:

a) Fatores predisponentes no enlutado: ser jovem (mais especificamente, criança); ter baixa auto-estima, dificuldade no relacionamento com os pais ou ter vivido muitas perdas anteriores. 
b) Fatores da relação com o morto: cônjuge (particularmente viúvas); um dos pais (especialmente filha pequena); adolescente enlutado que perde um dos pais; enlutado ambivalente ou dependente em relação ao morto; filhos, sobretudo com idade até cinco anos.

c) Tipo de morte: inesperada e prematura; após doença muito longa; enlutado ignorante do diagnóstico e do prognóstico; enlutado fisicamente distante por ocasião da morte; suicídio; assassinato.

d) Suportes sociais: sem filhos ou familiares próximos ou família considerada inútil como suporte.

Nesse contexto, Bromberg (2000) também enfatiza a importância do meio, mais especificamente da família, pois é no âmbito familiar que a experiência de morte pode adquirir significado humano, condição que favorece a elaboração da perda e do luto. Já Worden (1998) inclui a vivência de estresses concomitantes à perda e decorrentes dela.

Para Bowlby (2004b), certos tipos de personalidade são mais suscetíveis à perda do que outros e, em sua concepção, as características pessoais do enlutado são preponderantes na resolução do luto. A partir dessas considerações, ele apresenta cinco categorias:

a) Identidade e papel da pessoa falecida: no caso de pais, filhos e outras relações significativas, a superação e a reorganização da vida tende a ser mais difícil;

b) Identidade e sexo da pessoa enlutada: em geral, pessoas muito jovens têm mais dificuldade para resolver seu luto. Há indícios de que as mulheres são mais suscetíveis às perdas e têm mais dificuldade para se recuperar.

c) As causas e circunstâncias da perda: incluem-se aqui as mortes súbitas, os casos em que o falecido demandou uma longa assistência antes de morrer e aqueles em que há mutilações ou deformações do corpo. Nessa categoria, também se devem considerar o modo como o enlutado recebeu a notícia e a relação entre ele e o falecido pouco antes de sua morte, além do fato de se poder responsabilizar alguém por essa morte.

d) Circunstâncias sociais e psicológicas: condições de ordem social e psicológica que acompanham o enlutado por ocasião da perda e depois; se a pessoa enlutada mora só, se é responsável por crianças ou adolescentes, se as condições financeiras favorecem a organização de um novo modo de vida, se as crenças, valores e práticas culturais favorecem um luto sadio e se o enlutado conta com apoio social de parentes e amigos mais próximos para enfrentar essa perda.

e) A personalidade do enlutado: sua capacidade de estabelecer relações amorosas e de lidar com situações de estresse. 
Parkes (1998) preocupou-se em investigar os motivos pelos quais algumas pessoas passam pela experiência de luto sem se desarticular e outras precisam de ajuda psiquiátrica ou de outra área médica. Ao procurar explicar essas diferenças, levantou e estudou uma série de fatores que concorrem para a compreensão do que se passa com os enlutados:

a) Fatores que antecedem a perda: grau de parentesco entre o enlutado e o morto; características da relação entre eles como força e segurança do apego, grau de confiança, envolvimento e intensidade de ambivalência (amor e ódio) do enlutado para com o falecido; experiências infantis (especialmente maternagem insegura e perda de pessoas significativas) e posteriores (especialmente as relativas a perdas significativas) do enlutado; problemas de saúde mental no enlutado anteriores à perda ou vivência de uma crise vital por ocasião da perda.

b) Tipo de morte: morte por suicídio; morte prematura; mortes múltiplas; morte repentina; morte inesperada; morte violenta ou horrenda, resultantes de ação humana ou não; luto não autorizado (ou perda que não é socialmente validada, de relacionamento não reconhecido socialmente como vínculos extraconjugais, perdas não reconhecidas por sua natureza como, por exemplo, abortos e perdas em que o enlutado não é reconhecido como tal, como no caso de crianças que podem ser consideradas muito pequenas para estar em luto) ou morte que gera culpa.

c) Fatores relativos à vulnerabilidade pessoal do enlutado e simultâneos à perda: gênero (em geral, mulheres são mais vulneráveis); idade do falecido, pela previsibilidade ou não de sua morte; idade do enlutado, por sua vulnerabilidade, no caso de crianças, adolescentes ou idosos; personalidade do enlutado (como tendência ao pesar, à dependência, à inibição de sentimentos ou baixa auto-estima); status socioeconômico; nacionalidade; religião (crenças e rituais); fatores culturais e familiares influindo na possibilidade de expressão dos sentimentos relativos à perda.

d) Fatores posteriores à perda: apoio social ou isolamento; estresses secundários decorrentes da perda, bem como oportunidades emergentes (opções disponíveis para o enlutado se reorganizar).

No Brasil, em 1998, pesquisa idealizada e orientada pela Profa. Dra. Maria Helena Franco Bromberg e desenvolvida por Luciana Mazorra e Valéria Tinoco procurou identificar indícios de fatores de risco para a instalação do luto complicado numa população brasileira. Em suas conclusões, as autoras salientaram que é difícil elaborar a perda de entes queridos jovens, por morte repentina ou violenta e também observaram que a participação nos rituais do funeral e a crença em vida após a morte cooperam na elaboração do luto, avaliando-se a 
ausência dessas condições como fator de risco. Além disso, os segredos em torno das causas ou das circunstâncias da morte também prejudicam a resolução do luto.

Parkes (1998) assinalou que as conseqüências geradas pelo luto complicado e não resolvido são muito graves e danosas, tendo essa condição sido associada à depressão, ao desenvolvimento de doenças crônicas e a reações clínicas intensas e duradouras como culpa e prejuízos significativos na auto-estima, na performance escolar e profissional, bem como nos relacionamentos interpessoais. Esses efeitos são discutidos mais detalhadamente na análise específica do luto em adolescentes. 


\section{ADOLESCÊNCIA E LUTO}

\section{IV.1 ADOLESCÊNCIA}

O adolescente deste século está num mundo dominado pela tecnologia, sobretudo pela informática, pautado pela globalização, no qual atuam ferozmente os meios de comunicação de massa, explodem o uso de drogas e a violência urbana, a sexualidade é permeada pela aids e pelo uso da "camisinha", o consumismo predomina e impera um mercado de trabalho que exclui e exige sempre mais.

Nesse contexto, o interesse e a preocupação para com o adolescente intensificaram-se nos últimos tempos, em parte pelo fato de esse grupo constituir um importante e crescente segmento da população - segundo o IBGE (2000), no Brasil, somam cerca de 35 milhões -, mas também pela relevância das transformações que ocorrem nessa etapa do ciclo vital, na busca pela autonomia e por uma identidade própria, antes inviável (Pereira, 2004).

Curiosamente, a palavra "adolescência" tem duas possíveis origens etimológicas, que lhe atribuem sentidos bastante significativos, dado o contexto do adolescente: do latim ad (a, para) e olescer (crescer), que quer dizer "processo de crescimento", e também de adolescere, que significa "adoecer", "enfermar", ou a "dor de crescer". Essa dupla origem indica inclinação para crescer, no âmbito físico e psíquico, mas também para adoecer, apontando o sofrimento emocional decorrente das transformações biológicas, mentais e emocionais que marcam essa etapa da vida, angustiando o adolescente frente a um destino desconhecido (Muniz, 2004; Outeiral, 2003).

A adolescência é uma fase de transição gradual entre a infância e a vida adulta, caracterizada por transformações bio-psicossociais, e, embora se possam usar diferentes critérios para delimitar esse período, por razões de ordem prática, a adolescência tem sido comumente definida a partir de critérios cronológicos (Kuczynski, 1998).

A Organização Mundial de Saúde, que antes considerava a adolescência como uma etapa que se estendia dos 10 aos 19 anos de idade, atualmente estabelece que ela inclua indivíduos de 10 a 24 anos (Pereira, 2004).

Contudo, esses critérios cronológicos devem ser considerados a partir da compreensão de que representam limites mutáveis, sujeitos à cultura, à geografia e ao próprio indivíduo que vive esse processo de transformação, pois, além de existirem diferentes experiências 
adolescentes, a própria adolescência é constituída por diferentes fases (Muniz, 2004; Outeiral, 2003).

Acresce-se a essas considerações o fato de que hoje a humanidade passa por uma série de transformações, que se sucedem de forma extremamente dinâmica, o que implica que tudo muda muito depressa, determinando a coexistência de realidades diversas e mutantes, de modo que alguns podem ser precocemente conduzidos ao amadurecimento, e outros, levados à estagnação (Pereira, 2004).

O próprio conceito de adolescência, reconhecida por Ariès (1986) como juventude, constitui um fenômeno recente, socialmente construído entre o final da I e o começo da II Guerra Mundial; até então, o indivíduo passava em pouco tempo da infância para a vida adulta, após breves rituais de iniciação (Klosinski, 2005; Outeiral, 2003).

Além de ressaltar que a adolescência seria uma criação da modernidade e da cultura ocidental, Garcia (1999) cogita que essa etapa de vida pode ser uma criação do mercado, mais um clichê da publicidade, em que coexistem dois paradigmas opostos: a juventude representa ora o ideal da força e da realização, ora o incômodo e a apatia, haja vista o termo pejorativo "aborrescente".

Situada entre a infância e a maturidade ainda não atingida, a adolescência costuma representar uma época de conflitos e turbulências, de novos tipos de amizades, do desabrochar da sexualidade, de interesses mutáveis e de uma incipiente consciência. Essa configuração impele o adolescente a questionar e a abandonar o mundo infantil, bem como tudo o que ele inclui e representa, para se lançar a um mundo novo, desconhecido e fascinante, com uma preocupação central: “quem sou eu?” (Tommasi, 1998).

Liotta (1996) entende que o adolescente encontra-se num estágio da vida com identidade, status e experiência próprios, em que se ocupa com os desafios e as atribulações típicas da idade, o que pode ser tanto prazeroso quanto estressante, pois trata-se de ter novos papéis, responsabilidades e expectativas.

A abundante oferta de sexo, drogas e álcool pode colocar o adolescente numa posição comprometedora, devendo lidar com as de recusar, aceitar ou apenas experimentar, o que é freqüentemente significativo, sobretudo em função da pressão dos colegas. Além disso, personalidade, sexualidade e um grande desejo de independência emergem e convergem, enquanto o inocente jovem se sente feliz por não ser mais criança.

É um período caracterizado pelo humor inconstante e pela personalidade e pelo comportamento generosamente temperados com o espírito da rebeldia, pois, na tentativa de 
encontrar sua identidade, o jovem se torna errático, e sua vida é marcada por desarmonia e equilíbrio destrutivo, o que é considerado normal para esse período.

Osório (1989) caracteriza a adolescência ressaltando as demandas que então se propõem aos adolescentes:

- redefinição da imagem corporal, em função da perda do corpo infantil e da conseqüente aquisição do corpo adulto (em particular, dos caracteres sexuais secundários);

- ápice do processo separação/individuação, com a substituição do vínculo de dependência simbiótica com os pais por relações objetais autônomas;

- elaboração do luto relativo ao abandono da condição infantil;

- aquisição de uma escala de valores ou de um código de ética próprios;

- busca de pautas de identificação no grupo de pares;

- instituição de um padrão de luta/fuga no relacionamento com a geração anterior;

- adoção tácita de rituais de iniciação como condição de ingresso no mundo dos adultos;

- opção própria por funções ou papéis sexuais, independentemente das imposições biológicas ou sociais.

Para Outeiral (2003), a adolescência constitui-se por três fases cujo início e fim são pouco determinados, mas com algumas características que se sobressaem:

- adolescência inicial (de 10 a 14 anos): caracterizada basicamente por transformações físicas, as quais provocam uma série de alterações psíquicas;

- adolescência média (de 14 a 17 anos): marcada por questões relativas à sexualidade, notadamente pela passagem da bissexualidade para a heterossexualidade;

- adolescência final (de 17 a 20 anos): etapa na qual ocorrem eventos significativos como o estabelecimento de novos vínculos com os pais, a emergência de questões profissionais, a aceitação do novo corpo e dos processos psíquicos do mundo adulto.

Já segundo Balk (2000), em países industrializados, a adolescência se desenvolve em três fases: pré-adolescência, adolescência média e adolescência tardia, implicando a transição bem-sucedida da pré-adolescência para a adolescência tardia na ampliação do self, na aceitação de responsabilidades e no direcionamento na vida, o que significa que os adolescentes enfrentam os desafios de:

- determinar um caminho ou foco para o trabalho como um adulto; 
- tornar-se um indivíduo autônomo;

- manter relacionamentos e amizades íntimos.

Na concepção de Balk (2000), a pré-adolescência vai dos 10 aos 14 anos, sendo o ingresso na puberdade marcado pelo início dessa fase do desenvolvimento, embora essa extensão seja inexata, pois nem todo jovem entra na puberdade nessa idade.

Os desafios do desenvolvimento que os pré-adolescentes têm que superar envolvem adaptar-se a seu corpo, que está mudando, aprender novas habilidades sociais com colegas, familiares e outras pessoas, dominar material acadêmico mais facilmente, passar cada vez mais tempo com os colegas e adquirir cada vez mais autonomia em relação aos pais.

Já a adolescência média se estende dos 15 aos 17 anos e nessa fase os jovens demonstram crescente maturidade na tomada de decisões, passam mais tempo fora de casa e com os colegas, confiam mais em pessoas da mesma idade, e uma crescente parcela, além de ir à escola, trabalha. Para muitos adolescentes, questões de identidade pessoal se tornam proeminentes nessa fase e assim permanecem na adolescência tardia.

A adolescência tardia encerra essa etapa de transição e se prorroga dos 18 aos 22 anos. Os desafios dessa fase são a saída da casa dos pais, a conquista da independência e a formação de relacionamentos e amizades íntimas, além de se esperar que tenham mais facilidade para pensar sobre e lidar com as ambigüidades e complexidades da existência humana.

O cumprimento desses desafios é mais fácil quando o jovem consegue atender aos que enfrentou na pré e na média adolescência, de modo que adolescentes mais velhos que demonstram ambivalência em relação a responsabilidade, identidade e maturidade interpessoal comumente são indivíduos cuja transição para a idade adulta será difícil.

Entretanto, isso não significa que aos 22 anos a pessoa deixa a adolescência e entra na idade adulta, pois alguns chegam a essa fase ainda ambivalentes quanto à aceitação de responsabilidades, formando uma identidade separada e tentando tolerar a intimidade interpessoal, o que indica que é mais difícil identificar o fim da adolescência do que seu começo (Balk; Corr, 2001).

O início da adolescência se caracteriza por uma série de mudanças fisiológicas da puberdade, termo que designa todo o processo de maturação biológica que transcorre entre os 9 e os 14 anos e persiste durante grande parte da adolescência (Pereira, 2004; Outeiral, 2003).

A puberdade é um processo biológico marcado por uma intensa atividade hormonal, responsável pelo surgimento dos chamados caracteres sexuais secundários e pelo início da aceleração do crescimento. Mais tarde, essas condições permitem que se complete o 
desenvolvimento físico, com a parada do crescimento e o estabelecimento da função reprodutora (Outeiral, 2003; Kuczynski, 1998).

Contudo, a puberdade e a adolescência não necessariamente se sucedem ou são concomitantes, posto que esta é um fenômeno psicossocial. Assim, há crianças que adotam uma postura adolescente, ou seja, adolescem antes mesmo de se tornar púberes (Pereira, 2004; Outeiral, 2003).

A paulatina progressão da criança para a maturidade é perturbada pelas transformações corporais da puberdade, que lhe exigem grandes investimentos de adaptação a uma nova e complexa realidade, pois essas transformações alteram não só seu físico, mas também sua motivação e suas capacidades e as exigências do meio sobre ela (Tommasi, 1998).

Desse modo, para Turbert (1999), a adolescência gravita em torno de oposições entre o crescimento e a paralisia, entre aparecer e desaparecer do mundo, entre a síntese e a destruição, entre a progressão e a regressão, entre a vida e a morte. A autora propõe considerar-se a adolescência como uma estrutura mítica, em que é fundamental o confronto com a morte a partir da sexualidade e nela própria, e o resultado desse embate dependerá da solução - nunca definitiva - da permanente tensão entre o que se perde ou se destrói e o que se cria ou recria. Turbert (1999) entende que a morte, estrutura central dessa fase, está atrelada às perdas que a metamorfose sexual impõe: perda da imagem de si mesmo, perda da imagem da criança ideal - seja para a criança, seja para os pais -; perdas dos pais como sustentação do ideal infantil e da relação de dependência com eles.

Ao mesmo tempo, surgem aspectos novos, que não são exatamente novos, mas novas sínteses históricas, que vão se sedimentando de modo que se define a passagem para uma nova estrutura, pela adoção de uma nova encarnação simbólica de si mesmo (Turbert, 1999).

Nesse contexto, à medida que o desenvolvimento vai acontecendo, o adolescente se torna mais seguro e mais independente e busca autonomia em relação aos pais, afastando-se deles e procurando identificações fora do âmbito familiar, de forma que os pais idealizados pela criança são denegridos e desvalorizados pelo adolescente (Outeiral, 2003).

Em função disso, a adolescência muitas vezes é um período de dificuldades e conflitos familiares, durante o qual os pais se revelam confusos, perturbados e irritados com a conduta dos filhos, pois aquelas crianças que antes aceitavam suas opiniões e determinações passam a questioná-los e, muitas vezes, a se rebelar contra eles (Pereira, 2005).

Apesar de muitos pais compreenderem intelectualmente que esse é um processo típico dessa fase e necessário ao processo de crescimento dos filhos, na prática cotidiana eles tendem a colocar impedimentos que dificultam aos jovens a conquista desses seus objetivos. 
Além disso, muitas vezes o período da adolescência dos filhos coincide com um período de crise também para os pais, que comumente estão entrando na meia idade, ou seja, no momento em que seus filhos estão no auge de seu vigor físico e sexual, os pais se deparam com o fato de que já passaram essa etapa e rumam para o declínio biológico, o que pode ser aterrorizante numa sociedade que supervaloriza a juventude.

Ao mesmo tempo, contaminados pela confusão vivida pelos adolescentes, os pais também podem ter seus aspectos adolescentes reativados, assim como os irmãos mais novos, o que implica a adoção de sentimentos e condutas adolescentes por parte de todos e faz com que os próprios pais contestem o establishment vigente e se perguntem sobre o que fizeram ou não de sua vida (Outeiral, 2003; Pereira, 2005).

Evidentemente, as dificuldades desse processo dependerão de como os pais viveram sua adolescência, mas sem dúvida algum tipo de crise se instalará, o que pode ser muito útil para dar uma nova dimensão às relações e revitalizar os vínculos familiares (Outeiral, 2005).

Nos novos relacionamentos entre pais e filhos adolescentes, os pais devem reconhecer e estimular a crescente necessidade de autonomia de seus filhos, mas também considerar que eles não podem conquistar sua independência de um dia para outro e por isso precisam deles, pais, como uma base de segurança e estabilidade. No entanto, a relação que se estabelece entre pais e filhos é assimétrica e frágil, pois transitar entre necessidades que muitas vezes se confrontam e confundem (Pereira, 2003).

Concomitantemente, os filhos adolescentes vão amadurecendo emocional, social e sexualmente e se voltam cada vez mais para os colegas, para os melhores amigos e para os namorados, para quem transferem os vínculos afetivos que antes eram praticamente reservados aos pais, o que pode exigir muito desses pais em termos de adaptação.

Nesse sentido, o grupo passa a representar um espaço significativo para o desenvolvimento dos jovens: é fonte de identificações e também oferece diversas situações necessárias para seu amadurecimento, através da experimentação de papéis, para questionar valores e buscar referências. Além disso, personagens de grupos musicais, atletas, astros de cinema ou de televisão também podem ser importantes figuras de identificação, assim como professores (Outeiral, 2005; Pereira, 2003).

Nessa época, um dos principais contatos em grupo de que dispõe o adolescente é o grupo da escola, instituição que também tem o papel de simular a vida, ao adotar regras a serem seguidas, mas que, se forem transgredidas, não trarão conseqüências excessivamente danosas para o jovem, preparando-o para lidar com o limite, o que só se torna possível a partir 
das mudanças significativas que ocorrem em sua capacidade intelectual nessa fase (Tommasi, 1998).

Desse ponto de vista, Piaget (1970) presumiu que a partir dos 10 ou 12 anos, mais ou menos, o adolescente entra no estágio das operações formais e adquire a habilidade de transcender aquilo que percebe, de ir além dos objetos concretos, passando a dominar idéias e conceitos e começando a pensar como um adulto.

Essa aquisição implica inúmeras conseqüências: o jovem passa a compreender idéias abstratas, a imaginar outras possibilidades, não visíveis, a fazer deduções críticas e a enxergar um problema sob diferentes prismas. Além disso, o centro das decisões morais do adolescente reside cada vez mais nele mesmo (Hurd, 2004; Tommasi, 1998).

No entanto, em suas proposições, nem sempre o adolescente consegue levar em conta o possível e o real, de modo que para ele é fácil encontrar soluções para os problemas da humanidade, mas elas nem sempre são exeqüíveis, o que acaba por lhe estimular a criatividade, que a princípio se apresenta de forma impulsiva, difusa e caótica, mas que aos poucos se articula com a noção de limites e assume um caráter mais definido, mais integrado e mais produtivo (Outeiral, 2005).

Assim, com tantos desafios a enfrentar, pode-se concluir que o adolescente só consegue viver bem essa fase se sentir confiança a seu redor e em si mesmo, o que significa que ele precisa ser capaz de se definir em relação às principais figuras de sua vida, particularmente seus pais, seus principais modelos para a construção de sua identidade, o que nos remete a como se estabelecem e se rompem os vínculos na adolescência, especialmente com a figura paterna, foco deste estudo.

\section{IV.2 ADOLESCENTES EM LUTO}

Como vimos, a adolescência representa um momento de crise, na medida em que impõe ao jovem a tarefa de lidar simultaneamente com várias questões e conflitos de grande importância, mas se espera dele que amadureça e tome decisões no âmbito sexual, profissional e pessoal, posicionando-se no mundo de forma adulta (Pereira, 2004).

Em contrapartida, o adolescente ainda não se sente preparado para fazer essas escolhas, que fundamentalmente lhe impõe a perda do corpo infantil, dos pais da infância e de sua identidade infantil. Assim, para Bromberg (1996), a própria adolescência é em si um processo de luto, no qual o adolescente se vê impelido a abandonar a infância e o universo infantil para passar a viver experiências que demandam mais autonomia responsabilidade. 
Nesse contexto, o significado que o jovem atribui à morte depende de vários fatores, sobretudo de sua idade, ou do momento de seu desenvolvimento, em função do qual disporá de diferentes recursos para lidar com sua perda (Domingos; Maluf, 2003).

Sabe-se que, do ponto de vista cognitivo, o adolescente já tem condições de perceber as características essenciais da morte - universalidade e irreversibilidade - e pode dar respostas lógicas formais, condições relevantes para a resolução do luto (Kovács, 1992).

Vale lembrar que mesmo crianças que ainda não são capazes de realizar operações formais já conseguem perceber o que se passa à sua volta, inclusive a morte, cuja presença se evidencia através de atividades expressivas como o desenho e o jogo feitos em sessões de ludoterapia psicanalítica (Domingos; Maluf, 2003).

Worden (1996) ressaltou que a maioria dos profissionais concorda que a habilidade de lamentar é adquirida na infância, quando as funções do ego amadurecem e a criança é capaz de compreender a finalidade da morte, mas existe um longo e controverso debate sobre o momento preciso dessa aquisição.

Apesar das diferenças, Worden (1996) acredita que a maioria concordaria que, para que ocorra o luto, a criança deve ter atingido uma representação mental coerente das figuras de apego importantes como os pais, bem como uma constância de objeto, capacidades que se desenvolvem, em geral, entre os 3 e os 4 anos de idade. Além disso, pesquisas realizadas pelo autor sugerem que crianças e adolescentes vivem e expressam seu pesar de forma intermitente, por um período de tempo maior do que é típico no caso da maioria dos adultos, e é um desafio especial para muitos adolescentes não se descontrolarem nem denunciarem nenhum tipo de embaraço diante de seus colegas.

Liotta (1996) argumenta que só entre 8 e 10 anos é que a maioria das crianças deve ser capaz de formar um conceito mais maduro sobre a morte, incluindo sua permanência, universalidade e inevitabilidade, associado a uma compreensão de que a morte é uma parada total do funcionamento físico. No caso dos adolescentes, ocupados com os desafios e as atribulações próprias da idade, a morte não tem sentido, posto quase tudo na sociedade enfatiza o poder da vida, e as normas culturais tendem a tratar a morte como um tabu, do que decorre uma sensação de confusão, que os deixa completamente vulneráveis a uma enxurrada de sentimentos novos e até mesmo assustadores.

Entretanto, os adolescentes vivenciam as mesmas reações de luto que os adultos - o estresse, a angústia... -, mas também vêm ameaçada sua sensação de segurança e 
experimentam um desconfortável desamparo, condições que concorrem para que eles fiquem ainda mais assolados por uma intensa confusão geral.

Para Bromberg (2000), as dificuldades dos adultos para enfrentarem questões relativas à morte dificultam às crianças desenvolverem seus próprios conceitos, mas ela acredita que só a partir da adolescência é que se podem compreender as características básicas da morte, irreversibilidade, universalidade e causalidade.

Segundo Corr (2000), as expressões de luto de crianças e adolescentes são semelhantes e diferem das dos adultos. Entretanto, em comparação com as das crianças, as expressões dos adolescentes são inevitavelmente influenciadas por suas experiências adicionais de vida, por sua melhor habilidade de comunicação e por situações pessoais, além dos desafios do desenvolvimento por que passam.

Os desafios singulares dessa fase distinguem o luto desse período do de outros; aí, ele é mais intenso e suas conseqüências, únicas, pois uma má administração (e às vezes mesmo que seja boa) pode atrapalhar o desenvolvimento do jovem, apesar de evidencias de que ele pode se beneficiar com o gerenciamento das crises da vida (Balk; Corr, 2001).

$\mathrm{Na}$ verdade, ao tratar do luto na adolescência, muitos autores ressaltam a sobrecarga que a perda de uma pessoa significativa pode representar, já que, além de ter que dar conta das tarefas inerentes a essa fase, o jovem deve enfrentar exigências adicionais para elaborar seu luto (Pereira, 2004; Domingos; Maluf, 2003; Domingos, 2000; Kovács, 1992).

Acresce-se ainda o fato de que a perda significativa do adolescente pode ser a primeira de sua vida, o que é em si um complicador, pelo ineditismo da situação e também por sua dificuldade de falar sobre suas aflições e de compartilhar seus sentimentos, o que acaba sendo um obstáculo a mais para o enfrentamento dessa perda (Pereira, 2004).

Para Bowlby (2004b), os adolescentes também experimentam o luto como resposta ao rompimento de laços afetivos significativos, visto que esse vínculo tem um valor de sobrevivência, porque é na figura de vínculo que o indivíduo se apóia para se sentir confiante para explorar o mundo, protegido de eventuais ameaças.

Apesar de ser mais evidente nas crianças, esse comportamento de apego permanece até a vida adulta, e a perda de uma pessoa que representa um vínculo significativo se faz acompanhar por vivências de desamparo, o que detona inúmeras reações e pode causar intensa ansiedade (ansiedade de separação).

Bowlby (2002) ainda salientou que, em situações de estresse, o comportamento de apego tende a ser mais intenso, independentemente da etapa de desenvolvimento em que se 
encontra o indivíduo, defendendo que pessoas de qualquer idade são mais bem ajustadas quando podem contar com a acessibilidade e a responsividade de um outro confiável.

Contudo, na adolescência, o desenvolvimento do sistema de apego é assediado pelas inúmeras transformações que marcam essa fase, inclusive o fato de que o adolescente deve deixar de ser um receptor de cuidados para ser um potencial cuidador (Pereira, 2004).

Desse modo, o sistema de apego configura-se num cenário em que o jovem começa a ter uma visão mais consistente de si mesmo e adota posturas mais discriminadas e independentes das de seus pais, mas tem necessidade de explorar o ambiente e de ampliar sua rede relacional, apesar de a família ainda ser uma base segura para sua saúde mental.

Para Liotta (1996), os adolescentes são completamente capazes de sentir profunda dor pela morte de uma pessoa significativa e reagem a essa crise de acordo com suas expectativas, metas, sistema de crenças e a extensão de sua vulnerabilidade.

Nesse sentido, o jovem inicialmente tende a vivenciar descrença, negação e choque e comumente evita lamentar uma morte ou expressar emoções e, mesmo que sinta necessidade de participar dos rituais do funeral e de conversar sobre sua perda, há momentos em que prefere a privacidade, o que deve ser compreendido e respeitado.

Além disso, apesar de normalmente exibir uma ampla variedade de comportamentos, o adolescente geralmente sente raiva, seja da morte em si, na busca por um significado e no esforço de ver que a morte "tem sentido", seja por não ter tido controle - por não podido preveni-la -, seja mesmo do falecido, por tê-lo abandonado.

Com a raiva, o jovem pode manifestar sentimentos de culpa, porque sente que poderia ter interferido no curso dos acontecimentos ou que talvez tenha tido alguma responsabilidade na morte, e de novo a questão do controle pode ter um papel significativo nesse tipo de culpa.

Outro aspecto da culpa ocorre quando há fortes sentimentos negativos numa relação intima. Na maioria das relações íntimas, coexistem sentimentos positivos e negativos, e a ambivalência é habitual, mas, com a idealização pós-morte do ser amado, pode emergir uma forte culpa pelos sentimentos negativos.

Entre as possíveis reações dos adolescentes durante o período do luto, Liotta (1996) entende que algumas podem requerer maior cuidado - baixa auto-estima, tristeza, culpa, desamparo, percepção de rejeição e uma intensa negação da realidade da morte -, pois podem levar o jovem à agressividade, a comportamento anti-social de risco e até à ideação suicida. Esta pode ser indicada por sentimentos intensos de raiva e negação, pelo uso de álcool ou de drogas, pela troca de amigos ou de interações sociais, pela perda da esperança ou da auto- 
estima, pela desistência de posses valiosas, por sentimentos de tristeza ou depressão, pela verbalização de pensamentos suicidas e por comportamentos de risco, meses após a perda.

Balk (2000) salientou as diferenças que se observam nas vivências de luto dos adolescentes dependendo da fase do desenvolvimento em que se encontram: pré-adolescência, de 10 a 14 anos, adolescência média, de 15 a 17 anos, e adolescência tardia, de 18 a 22 anos. Essas fases e os desafios de cada uma têm instigado o uso de um modelo para a compreensão do luto na adolescência proposto por Fleming e Adolph (1986), citados por Balk e Corr (2001) e Balk (2000). Nesse modelo, o adolescente em seu luto deve enfrentar comportamental, cognitiva e afetivamente cinco questões centrais, de acordo com seu nível de desenvolvimento:

- confiar na previsibilidade dos eventos;

- adquirir um senso de domínio e controle (auto-eficácia);

- criar relacionamentos baseando-se na idéia de pertencer;

- acreditar que o mundo é bom e justo;

- desenvolver auto-confiança.

Balk (2000) também ressaltou o entendimento do luto como uma situação desgastante que ameaça o equilíbrio social e psicológico de uma pessoa e que desafia suas estratégias típicas de enfrentamento, constituindo, por definição, uma crise da vida. Paradoxalmente, essa crise representa uma ameaça e uma oportunidade de crescimento e maturidade, de modo que, a partir dessa concepção, também se pode entender o luto como uma situação de estresse e adotar modelos que fornecem a compreensão do fenômeno desse ponto de vista. Complementando, o autor afirma que, para o adolescente, a perda e o luto são crises que impõem severos obstáculos à superação dos desafios de seu desenvolvimento, mas que, se forem enfrentados com êxito, podem levar o jovem a uma maior maturidade e apreciação da vida e dos outros.

Mas o que faz com que alguns adolescentes sucumbam à ameaça que o luto representa e outros, não?

Bowlby (2004b) considerou que a resposta do adolescente à perda e o desenrolar do curso desse luto são influenciados por vários fatores, que, embora não sejam muito diferentes dos que condicionam o luto do adulto, afetam mais os adolescentes, que são mais vulneráveis às condições que antecedem, cercam e sucedem a perda significativa. Esses fatores englobam: 
- causas e antecedentes da perda, especialmente no que se refere ao que é informado para o jovem, a abertura para que ele pergunte sobre o que aconteceu e a possibilidade de poder compartilhar sua perda;

- relações familiares depois da perda, principalmente quanto às mudanças dos padrões de relacionamento, mas também quanto à permanência com o genitor sobrevivente;

- padrões de relacionamento da família antes da perda, principalmente entre os pais e de cada um deles com o jovem.

Domingos (2000) ressalta que, independentemente da etapa de desenvolvimento em que se encontra o enlutado, todos precisam da assistência de uma pessoa confiável com quem possam compartilhar seus sentimentos, mesmo os ambivalentes, de modo que os conteúdos expressos sejam contidos e legitimados.

A inibição ou a supressão da manifestação de sentimentos e emoções relativas à perda pode provocar vivências de culpa e de inadequação, conteúdos que podem ser comunicados pelos adolescentes por outras vias de expressão como agressividade, atitudes de desafio a figuras de autoridade, uso e abuso de drogas, problemas que tradicionalmente rondam e ameaçam os adolescentes.

Portanto, as tentativas dos adultos de proteger os adolescentes e procurar evitar que se confrontem com a morte tendem a não serem positivas, pois saber o que acontece, falar sobre a morte e sobre o morto alivia a dor e a sensação de desamparo. Essa é uma das condições que favorecem a resolução do luto, ao passo que o escamoteamento da verdade faz com que sintam que foram enganados ou considerados ingênuos, incapazes (Pereira, 2004; Corr, 2000).

Alguns autores (Hurd, 2004; Rutter, 1999) têm usado o conceito de resiliência capacidade humana de enfrentar, vencer e ser fortalecido ou transformado por experiências de adversidade (Grotberg, 2005) - para explicar por que algumas crianças e adolescentes enlutados enfrentam dificuldades a ponto de desenvolverem sérios problemas e outros, não.

A compreensão do conceito de resiliência implica a definição de adversidade, descrita por Sandler (2001) como um contexto estabelecido entre uma pessoa e seu ambiente que compromete a satisfação das necessidades e dos alvos humanos, impedindo com isso a realização apropriada do processo de desenvolvimento.

Nesse sentido, Rutter (2002) observou que, apesar de o luto em crianças aumentar o risco do desenvolvimento de psicopatologias, estudos epidemiológicos indicam que, por si, esse não é o principal fator para o surgimento de psicopatologias. Seus estudos sobre 
resiliência em crianças indicaram que ela se apóia em bases ambientais e constitucionais, e não tem grau fixa, mas variável de acordo com as circunstâncias.

Hurd (2004), que também considerou o conceito de resiliência para entender o luto saudável - sem depressão ou outros efeitos debilitantes - de uma adolescente que perdeu o pai, levantou aspectos que considerou protetores: suporte familiar, forte auto-conceito e capacidade de pensar positivamente.

É importante observar ainda que a experiência e a expressão de pesar em crianças e adolescentes são inevitavelmente influenciadas, com o passar do tempo, por novos desafios como as exigências normativas do desenvolvimento e também por exigências não normativas ligadas a outros eventos significativos da vida, que podem estimular a renovação do luto e novas maneiras para sua expressão (Corr, 2000).

$\mathrm{Na}$ verdade, crianças e adolescentes procuram enfrentar a perda e o luto com recursos concretos em termos do que realmente entendem sobre o significado e as implicações dessa experiência, o que lhes exige muito e envolve esforços para encontrarem maneiras de viver, adaptarem e integrarem a perda e o luto em sua vida.

Pesquisas têm mostrado que os jovens de luto mantêm algum tipo de conexão com a pessoa falecida que amavam. Mesmo que o enfrentamento da perda seja bem-sucedido e o enlutado siga em frente, amando e vivendo de maneira saudável, isso que não quer dizer que o luto tenha acabado para sempre ou que ele nunca mais será sentido.

Contudo, devido à vulnerabilidade típica dessa fase do desenvolvimento, a adolescência tem sido considerada um fator de risco para o luto complicado, pois sabe-se que a perda nessa etapa da vida tem sido temas proeminentes em muitos modelos de psicopatologia, percebidos como fatores de risco para a doença mental (Bowlby, 2004b; Pereira, 2004; Domingos, 2000, 2003; Bromberg, 2000; Parkes, 1998).

O luto não resolvido na adolescência tem sido associado à depressão, a doenças crônicas e a intensas reações clínicas como culpa e prejuízos significativos na auto-estima, na performance escolar e profissional e nas relações interpessoais (Balk; Corr, 1996), especialmente a morte dos pais.

Nesse âmbito, a morte de um dos pais é um dos maiores problemas com que se pode deparar um adolescente, e esse tipo de perda pode ameaçar seu processo de aquisição de independência e autonomia, principalmente se ela ocorre nas primeiras fases da adolescência (Hurd, 2004; Pereira, 2004; Domingos; Maluf, 2003).

Sabe-se que a perda de um dos pais é um evento quase sempre marcante para os filhos, difícil para grande parte deles, e, para um adolescente, essa perda é inesperada, fora de hora, 
pois, em geral, trata-se de pessoas na faixa dos 40 anos, mas não se pode desconsiderar que a experiência de luto é condicionada por uma combinação de fatores individuais, familiares e sociais, assim como os relativos às circunstâncias da perda (Pereira, 2004).

Assim, para viver o luto pela morte de seu pai, um jovem pode contar com fatores como os ambientes físico e social, a qualidade de seu relacionamento com a mãe e com outros familiares e a disponibilidades destes, além do apoio dos amigos e do ambiente escolar como vias de manifestação do luto.

Além disso, essa experiência pode fazer com que o jovem sinta-se diferente dos demais, exigindo-lhe que lide com sentimentos e conflitos decorrentes dessa relação e dessa perda (que podem ficar mascarados ou ser vividos muito solitariamente), mas também com que se sinta mais amadurecido, apesar de cada um ter seu jeito particular de atravessar o luto.

Domingos (2000) salientou que a morte de um dos pais na adolescência é uma situação de crise, mesmo quando a perda é de figura paterna ausenta da vida do jovem, pois pode ser vivida de forma particularmente intensa (Domingos, 2000).

Worden (1996) enfatizou que, quando um pai ou uma mãe morre, a vida da criança ou do adolescente muda radicalmente, sendo esse um momento de dor e confusão tanto para o filho enlutado quanto para o genitor sobrevivente, de modo que as reações emocionais e comportamentais do filho são fortemente influenciadas pelas reações dos pais sobreviventes e de outros adultos.

Quanto aos pais sobreviventes, Worden (1996) apontou alguns fatores que devem ser analisados, por sua interferência na condição dos filhos enlutados de reagirem à perda: nível disfuncional do sobrevivente, o quanto o pai ou mãe sobrevivente percebe seu filho adequadamente (presença de discrepância perceptual), consistência da disciplina e o namoro ou segundo casamento do sobrevivente. $\mathrm{O}$ autor ponderou ainda que há outras varáveis, que também conduzem as reações das crianças e dos adolescentes à morte do pai ou da mãe, e que merecem ser acompanhadas:

- as circunstâncias da morte (quanto mais súbita e mais misteriosa, é mais difícil de se aceitar);

- os rituais do funeral, que podem favorecer a criança ou adolescente a constatar a realidade da perda e lhe dão a oportunidade de receber apoio e de homenagear o falecido; as crianças mais preparadas para essas situações são as que apresentam menos problemas e, nesse sentido, é importante que os enlutados tenham a opção de escolher se querem ou não participar; 
- o gênero do falecido: a perda da mãe tende a ser uma perda mais difícil, exceto para garotos pré-adolescentes, que geralmente apresentam mais problemas quando perdem o pai;

- o relacionamento entre o filho e o falecido: a força da ligação, questões de dependência e sobretudo o grau de ambivalência;

- o tamanho da família: famílias com muitos fillhos tendem a afetar o funcionamento do pai ou mãe sobrevivente, mas a presença dos irmãos pode trazer algum conforto;

- o grau de união familiar, num continuum estrutural de desligada a simbiótica;

- a presença de estressores concomitantes na família;

- o estilo de enfrentamento mais ativo, mais positivo, tanto para pais como para crianças e adolescentes;

- a situação financeira e o status socioeconômico da família: a falta de recursos financeiros representa um estressor a mais que a família precisa enfrentar;

- a idade e o gênero do filho e o gênero correspondente com o falecido (mas que são fatores que em geral pouco influem);

- a compreensão que tem da morte a criança ou o adolescente.

Particularmente em relação aos adolescentes, Worden (1996) acrescentou que os enlutados eram mais ansiosos e medrosos, com o passar do tempo, do que os outros, o que o fez supor que a morte de um dos pais lhes tenha agravado a sensação de imprevisibilidade. Sobre a auto-imagem dos adolescentes de luto, o autor constatou que eles consideravam sua conduta e sua performance acadêmica inferior à dos colegas que não estavam de luto, mas que também se achavam mais maduros, o que sugere que talvez esta última percepção fosse compensatória de seus déficit de auto-estima.

Já no que diz respeito à integração com outros adolescentes, Worden (1996) concluiu que os enlutados tinham mais dificuldade de entrosamento do que os demais, pois gerenciavam menos eficazmente uma questão central do desenvolvimento nessa etapa da vida que é o senso de pertencer a um grupo ou a uma comunidade.

Finalizando este levantamento teórico sobre o luto na adolescência, vale acrescentar que, embora desde o início dos anos 1980, o tema venha merecendo crescente atenção dos estudiosos no cenário mundial, ainda há poucos estudos brasileiros que o explorem, mesmo quando se considera o luto do adolescente após a perda de um dos pais, o que atesta a relevância dessa pesquisa (Pereira, 2004; Balk, 2000). 


\title{
V. RESULTADOS
}

\section{V.1 ANÁLISE DAS ENTREVISTAS}

\author{
V.1.1 Caso K.
}

\section{Características do adolescente e de sua perda}

\section{Apresentando K.}

Quando participou desta pesquisa, a jovem K. tinha 18 anos, cursava o $3^{\circ}$ ano do ensino médio e fazia estágio remunerado como atendente na enfermaria da escola onde estudava, preparando-se para prestar vestibular para psicologia.

Quando ela nasceu, seus pais eram recém-casados e muito jovens; a mãe, com 16 anos, ainda estudava e o pai, com 21, iniciava sua vida profissional, de modo que o casal enfrentou muitas dificuldades para criar os filhos.

No entanto, K. os descreveu como "um casal sempre unido, que se gostava, que eram carinhosos", embora, ainda de acordo com a jovem, eles também tivessem suas desavenças, como todo casal.

Desde seu nascimento, K. passava muito tempo na casa dos avós maternos e, com o tempo, passou a morar com eles, apesar de continuar a manter contato contínuo com sua família de origem.

Nesse sentido, K. parece repetir a história de sua mãe, pois seus avós maternos, com quem ela foi morar, são de fato seus tios-avós e foram eles que criaram a mãe de K..

Entretanto, embora os avós biológicos de K. não tenham criado sua mãe, como todos moravam muito próximos uns dos outros, a convivência entre eles sempre foi intensa e constante.

K. é a primeira de quatro filhos; dois meninos, de 14 e 11 anos, e uma menina de 8, sua irmã só por parte de mãe, de pai desconhecido.

Há cerca de dois anos, a mãe de K. se casou novamente, mas faz dois anos que seu atual marido foi trabalhar no Japão, com a perspectiva de que a mulher fosse encontrá-lo depois, o que não aconteceu. 
Entretanto, esse padrasto mantém contato contínuo com a família de K. e mensalmente envia dinheiro do Japão para a mulher, que, hoje com 34 anos, ainda recebe pensão pelos filhos menores de idade.

Como K. já completou 18 anos, ela passou a receber parte da pensão deixada pelo pai, dinheiro que entrega para a mãe, pois seus avós maternos lhe suprem todas as necessidades, além de ajudarem financeiramente a mãe de K. e seus irmãos, sempre que necessário.

Nos fins de semana, K. costuma visitar a mãe e os irmãos ou ficar com o namorado, na casa da família dele. Ela namorava havia dois anos e nove meses com esse rapaz, que conheceu através de um colega de escola, amigo dele.

Durante a entrevista, K. pareceu bem motivada a participar, embora bastante mobilizada emocionalmente, principalmente durante o primeiro encontro; em vários momentos, ela chorou ou se mostrou confusa e insegura em seu discurso.

Ao final de sua participação, K. agradeceu pelo convite, concluindo que, para ela, a experiência tinha sido muito positiva, pois ela pôde falar de sua perda de um modo que nunca antes tinha tido a oportunidade de fazer.

\section{Sua perda: a história de $\mathrm{K}$.}

K. tinha 8 anos de idade quando seu pai foi assassinado. Ele fazia um trabalho autônomo, como segurança, e, durante um assalto, um tiro o acertou na nuca, aos 32 anos de idade. Na época, dez anos atrás, K. tinha um irmão de 4 anos e sua mãe estava grávida de um menino, que veio a nascer dias depois da morte do pai e recebeu seu nome, como uma homenagem.

Na noite da morte do pai, K. achou "engraçado" ver os parentes reunidos em sua casa, chorando, pois ninguém lhe contara o que tinha acontecido. Ela só soube da morte do pai dias depois, por uma tia, que mentiu, dizendo que ele tinha sofrido um acidente de carro.

Só anos depois é que ela soube a verdade, mas até hoje $\mathrm{K}$. tem dúvidas quanto às circunstâncias da morte de seu pai, pois em sua certidão de óbito consta que ele se matou, versão que contradiz a que foi dada à jovem e é negada por sua mãe.

No entanto, nem K., nem a mãe conseguiram esclarecer essa controvérsia, pois ambas acreditam que para isso teriam que pedir ajuda a irmã do pai, também policial, e que, na concepção delas, poderia investigar os fatos. Entretanto, K. não tem coragem de fazer isso, alegando que o pai morreu há muito tempo e que não tem muito contato com essa tia. 
Como K. só soube da morte do pai dias mais tarde, ela não foi nem ao velório, nem ao enterro, mas durante a entrevista disse que gostaria de ter ido para "ver ele pela última vez". De acordo com ela, como sua família é evangélica, não houve cerimônias religiosas alusivas à morte do pai.

Sobre seu relacionamento com o pai antes de sua morte, ela só tem algumas lembranças como o fato de que ele era muito apegado a seu irmão e o de que, quando ela brigava com o irmão, por ser a mais velha, era sempre responsabilizada pelo pai e às vezes apanhava dele.

Mas ela também se lembrou de que o pai se responsabilizava por ela quando vinha algum bilhete da escola para ser assinado, brincava com ela, deixava que ela pintasse as unhas dele de vermelho e era muito carinhoso, como quando massageava as pernas dela.

Sua última lembrança do pai é o fato de ele ter atendido a um pedido seu, comprandolhe, dias antes de sua morte, uma boneca que ela queria - que ela guarda até hoje e em que não gosta que ninguém mexa.

Ela contou também que mantém fotos dele e vídeos em que ele aparece com a família na praia, onde ele costumava levar a mulher e os filhos na passagem de ano. Mesmo hoje, às vezes, ela fica assistindo a esses vídeos seguidamente.

\section{Vivências e manifestações relativas à perda e ao processo de luto}

\section{Reações imediatas}

K. só ficou sabendo da morte do pai dias depois do ocorrido, mas contou que no momento em que soube ficou triste e nervosa e começou a chorar, recusando-se a aceitar que fosse verdade. Hoje, ela diz que é difícil explicar o que sentiu:

"[...] acho que não demorou tanto tempo assim, acho que foi uma semana, mais ou menos. Aí que eu 'tava brincando na minha prima, lá no quinta,l mesmo, aí, minha tia chamou e falou que ia contar uma historinha - aí, me contou. É. Eu fiquei bastante triste. Na hora, eu não acreditava. Eu comecei a chorar... [ela se emociona e chega a chorar]. Aí, fiquei nervosa, ela me deu chá, tudo... Aí, assim, eu não acreditava... [...] Não dá pra explicar o que eu senti, o que eu...” 


\section{Vivências e manifestações subseqüentes}

Durante algum tempo, quando se aproximava o final de semana, como K. sabia que nesses dias seu pai habitualmente não trabalhava, ela ficava à espera dele, achando que ele chegaria a qualquer momento. Mas, aos poucos, como ele não chegava, ela foi acreditando e se adaptando à nova realidade:

“[...] eu não acreditava, só que... Chegava o final de semana, eu falava pra minha tia 'ah, hoje o meu pai não vai trabalhar', sabe? Eu não acreditava. Eu falava assim 'vou ver se é verdade, porque hoje é dia que ele não trabalha, daqui a pouco, ele chega', sabe? Ficava esperando... [chora um pouco] Aí é que eu fui acreditando, né? Fui me acostumando, tudo."

Além disso, logo depois da morte de seu pai, K. também teve dificuldades para se alimentar, até o dia em que uma prima de sua mãe lhe disse que, se o pai dela, lá de cima, a visse chorando e se recusando a comer, ficaria triste, pois ele queria vê-la feliz:

"No começo, só... Normal... Falavam que eu não queria comer, no começo, sei lá... Aí, minha avó falava: 'K., tem que comer', não sei o quê. Eu ficava chorando, sempre eu chorava, né? Aí, uma prima da minha mãe também falou que, se eu 'tô chorando, ele 'tá lá em cima, feliz, e quer me ver feliz também, essas coisas, sabe? Que mais? Só isso..."

$\mathrm{O}$ choro foi uma reação de $\mathrm{K}$. à morte de seu pai, que sempre estivera presente, principalmente nos primeiros tempos, mas não só. No início, as pessoas reagiam, pedindo-lhe que parasse, o que a princípio lhe pareceu "idiota" [sic], pois, se era ela quem sentia vontade de chorar, como ela podia parar, só porque as pessoas pediam? Mas, depois, ela concluiu que as pessoas faziam esse pedido com o intuito de ajudá-la:

"[...] falavam que, se eu chorasse, ele ia ficar triste, que eu tinha que fazer as coisas para ele ficar feliz, que ele ia estar sempre me vendo, essas coisas... No começo, eu pensava 'ah, que idiota, né? eu que 'tô sentindo, como é que eu vou parar de chorar?' Daí, depois você vê que eles querem te ajudar..."

$\mathrm{Na}$ época em que seu pai morreu, K. já estava na escola e não queria que lá ninguém soubesse da morte de seu pai, pois não ter pai a fazia se sentir diferente das outras crianças. Ela acreditava ser a única criança nessa condição, o que a fazia sentir-se pouco à vontade, 
constrangida diante das pessoas. Nesse sentido, uma situação difícil para ela era quando na escola havia alguma festinha e os pais eram convidados, especialmente, o Dia dos Pais:

\begin{abstract}
"Que nem, na 1" série, eu não estudava aqui, né? Na outra escola, ninguém sabia, eu não queria, não sei... Eu 'tava na outra, né? Eu não queria que ninguém soubesse. Aí, um dia, ela deu um trabalho da família; a professora devia saber, mas, como eu era criança, bobinha, ela chegou para mim e $[\ldots]$ queria saber. Eu virei para ela [...] e comecei a chorar. Aí, eu falei 'mas não fala pra ninguém'. Ela falou 'pode deixar'. Aí, ela falou que sentia, mas o professor sabe, da documentação dos alunos, mas ninguém sabia... Quando eu entrei nessa [escola], eu já me senti mais à vontade, porque, aqui, não era só eu; como era uma escola grande, muito aluno aqui é órfão, muito.”

"É, eu achava que era só eu, que não existia isso, sabe? Essas coisas... Eu via todo mundo de pai, aí, 'hoje meu pai que vai me buscar', 'meu pai que vai me deixar', sabe essas coisas? Eu sinto falta disso, assim. Mas aqui também, lógico, na festinha do Dia dos Pais, aqui já, pra quem perguntava, eu já falava a verdade, que eu não tinha pai. Aí, tive que contar toda a história."
\end{abstract}

\title{
Vivências e manifestações atuais
}

A adolescente disse que sente mais falta de seu pai hoje do que antes, pois agora, aos 18 anos, ela se acha mais capaz de entender as conseqüências dessa perda, principalmente após a morte súbita do pai de seu namorado, ocorrida seis meses antes, devido a um acidente.

Ela contou que a morte do pai do namorado a fez começar a pensar que as pessoas podem morrer a qualquer momento, o que a levou a questionar o significado da morte e a refletir sobre suas conseqüência de um modo que jamais fizera antes.

Depois disso, ela passou também a temer a morte das pessoas que lhe são caras e, para aplacar sua angústia, costuma beijá-los e abraçá-los sempre, com freqüência:

"Mudou também que... não quando o meu pai morreu, mas, depois que o pai do meu namorado morreu, eu fico pensando 'o meu pai, o pai dele, por quê?' E também eu pensei assim, toda vez que eu saio de casa, eu dou beijinho na minha avó, no meu avô, pois a qualquer hora pode ir alguém, sabe? Agora. Agora. Sente mais agora. Que foi tão de repente, do pai dele. O meu pai também, né? Não foi doença. Porque doença, a gente espera, a pessoa fica internada, essas coisas... Mas acidente, ninguém espera. De repente. Aí, eu fico pensando no meu pai, no pai dele. De repente, pode acontecer a qualquer um, né? Mas só agora que eu amadureci mais em relação a isso, sabe? Que eu entendi mesmo, eu senti de verdade, sabe? Tanto que o tempo todo eu beijo minha avó, minha tia, meus irmãos... Eu beijo, abraço. Eles até me empurram, né?" 
Além disso, atualmente K. acredita que, se seu pai ainda estivesse vivo, casado com sua mãe, ele a ajudaria a cuidar dos outros filhos, que estariam em melhores condições do que estão sem a presença dele. Segundo ela, sua mãe "é meio cabeçudinha" e, apesar de se preocupar com os filhos, às vezes "dá umas loucas nela" e ela sai, deixando-os sozinhos, de modo que eles freqüentemente ficam à vontade para fazer o que bem entendem.

Nesse sentido, ela acrescentou que, meses antes, após ter se desentendido com a avó, ela tentou morar com a mãe e os irmãos, mas logo voltou para a casa da avó, pois, com a constante ausência e liberalidade de sua mãe, K. se sentia mal, tendendo a cuidar dos irmãos, por se sentir meio responsável por eles:

"Pra falar a verdade, eu acho que eu sinto mais falta dele agora... não assim... para ele poder ajudar minha mãe, sabe? Minha mãe é tão novinha... E ela é meio cabeçudinha, sabe?”

"Em relação aos meus irmãos, eu acho. Porque eu acho que, se ele estivesse vivo, talvez ele ajudasse melhor, né? É lógico, né?"

"Aí, eu peguei e fui morar com a minha mãe. Aí, minha mãe deixava tudo. Eu podia tudo e tal... Tinha dia até que eu falava 'mãe, fala que eu não posso sair, pelo amor de Deus. Eu não quero, sabe?' Aí, 'tá, ela foi começando a ficar rebelde, aí, eu não agüentei e voltei a morar com a minha avó. Porque a responsabilidade dela veio toda pra mim, que ela saía, eu tinha que olhar meus irmãos, tinha... Isso foi tudo este ano. Eu comecei a trabalhar em fevereiro. Eu acordava cedo, vinha para a escola, ficava aqui no estágio, à tarde. Eu chegava em casa cansada e morta de fome, certo? Eu chegava em casa, ela não tinha feito comida; ela 'tava chegando ainda pra fazer comida. Tinha dias que eu chegava, ela não 'tava lá, não tinha ninguém. Acho que você precisa de alguém pra... E, na minha avó, não; sempre tive tudo o que eu quis, acho que fui até mal acostumada. Aí, agora, eu chego, tem comidinha fresca, sabe essas coisas? Aí, voltei a morar com a minha avó, só que eu voltei mais meio que não querendo, sabe? Por causa dos meus irmãos - 'ah, vou ter que deixar eles, não sei o quê'. Porque eu meio que cuidava deles, sabe? Foi bem difícil, pra mim, voltar."

K. comentou também que, atualmente, costuma pensar muito em quem a levará para o altar, quando ela se casar, ocasiões em que pensa muito no pai, lamentando sua ausência, embora, às vezes, desqualifique esse seu desejo, considerando-o "uma besteira":

"Eu acho que sim, viu? Porque eu sinto muita falta dele, igual eu te falei. Eu fico pensando - eu sei que é besteira, né? Por que tem que ficar pensando no casamento, em quem vai entrar comigo, se é meu avô, que me criou, essas coisas? Ah, de tudo. Fico imaginando se ele ia... Ele ainda ia estar casado com a minha mãe, sabe? Eu sinto bastante falta dele." 
Por fim, K. contou que, hoje em dia, muitas vezes se questiona sobre o significado dessa morte, sentindo-se injustiçada, com saudade do pai, mas, ao mesmo tempo, confusa a respeito de seus sentimentos sobre essa perda:

"Também que... não quando o meu pai morreu, mas depois que o pai do meu namorado morreu, eu fico pensando 'o meu pai, o pai dele, por quê?"

"Por que comigo? Tem tanta gente ruim no mundo! É um pensamento chato, feio e egoísta, né? Mas, sei lá, não quero isso pra ninguém, é horrível. Porque pai é pai, mãe é mãe, vai fazer falta..."

"Acho que o que eu sinto é saudade, mas, na hora, não dá pra explicar."

"Não sei, também. Não é que eu não sei - tem hora que eu não sei explicar o que eu sinto, sabe?"

\section{Fatores de risco (vulnerabilidade) para luto complicado}

\section{Fatores predisponentes no enlutado}

Entre os fatores que predispõem a jovem ao luto complicado estão sua idade quando perdeu o pai ( 8 anos), ser menina - filha pequena que perdeu o pai - e sua baixa auto-estima (Bromberg, 2000), que se revela em vários momentos da entrevista, quando ela desqualifica sua condição, seus desejos e mostra que se sente confusa e insegura quanto a suas percepções:

\footnotetext{
"É, eu achava que era só eu, que não existia isso, sabe? Essas coisas... Eu via todo mundo de pai, aí, o pai, hoje meu pai que vai me buscar, meu pai que vai me deixar, sabe essas coisas?"

"Eu fiquei com medo de não saber responder... Fiquei, ah... só isso. Fiquei com medo, assim... Não sei, também. Não é que eu não sei - tem hora que eu não sei explicar o que eu sinto, sabe?"
}

\section{Fatores da relação do adolescente com seu falecido pai}

A relação que K. mantinha com o pai quando ele morreu era de bastante dependência, por conta da natureza do vínculo pai e filha, da idade da menina na época, mas também porque o pai participou da vida dela ativamente enquanto vivo: “Ah, isso aí, se o meu pai não tivesse... Aí, era a minha avô, né? Já 'tava em casa. Mas a responsabilidade de pai e de mãe era dele." 


\section{Fatores relativos à perda $\mathrm{em}$ si}

A notícia da morte de seu pai só foi dada a K. dias após sua ocorrência, mas a verdade lhe foi omitida, pois sua tia, que foi quem lhe deu a notícia, contou-lhe que o pai tinha sofrido um acidente de automóvel:

"Aí, depois, uns outros... [...] Porque, quando eles me contaram, falaram para mim que ele tinha morrido porque bateu o carro, não falaram a verdade."

Só recentemente, anos depois da morte de seu pai, foi que K. soube o que realmente acontecera, o que significa que durante todo esse tempo houve um segredo a respeito desse óbito, ou seja, a jovem foi tratada como se fosse incapaz de lidar com a verdade, condição que provavelmente dificultou sua aceitação da morte do pai e sua vivência do luto:

"Aí, agora, que eu cresci, eles me falaram a verdade - que ele levou um tiro."

Além disso, mesmo hoje, a morte de seu pai permanece cercada de mistérios, pois, enquanto a família foi informada de que ele fora assassinado, o atestado de óbito registra que ele cometeu suicídio:

"Minha mãe falou, minha tia também é policial, a irmã do meu pai. Eu não sei nem se tem a ver o que eu vou te falar, mas... Minha mãe falou que, nesse dia que ele foi trabalhar fazendo esse bico, era pra minha tia ter ido; um pouco antes, minha tia tentou falar com o meu pai, mas ela não conseguiu, e o meu pai acabou indo trabalhar. E a madrasta do meu pai, da minha tia - a minha avó, né? - ela é advogada, ela ia cuidar desse caso, que, na polícia, eles deram como o meu pai que se matou... Foi, que o meu pai que se matou, ela ia cuidar desse caso. A minha mãe falou que, quando ela foi conversar com a minha tia, aí, depois que ela conversou com a minha tia, ela desistiu do caso. Ela não quis mais saber, não queria mais ajudar... A minha mãe falou pra mim até perguntar pra minha tia, mas eu não tenho coragem, depois de tanto tempo."

"Ah, só isso, mesmo. Achei estranho, né? Minha mãe também achou. E eu não acredito que o meu pai tenha se matado; a minha mãe também não, ninguém, né? Só se... tiveram... um motivo, lá, e eu não entendo o por quê." 
Por fim, a morte do pai de K. se deu por assassinato, de forma súbita e violenta, condições que também representam fatores de risco para luto complicado, cenário que se compromete ainda mais quando se considera a possibilidade de um suicídio, morte que tende a dificultar a resolução do luto tanto ou mais do que uma perda por morte súbita e violenta:

\begin{abstract}
"Aí, ele 'tava numa loja - foi o que minha mãe explicou, né? - ele 'tava numa loja, fazendo bico, de segurança, e iam roubar a loja, e ele não queria deixar; aí, deram um tiro nele. Daí, o tiro pegou na nuca, assim."

“Agora. Agora. Sente mais agora. Que foi tão de repente, do pai dele. O meu pai também, né? Não foi doença. Porque doença, a gente espera, a pessoa fica internada, essas coisas... Mas acidente, ninguém espera...."

“[...] que na polícia eles deram como o meu pai que se matou."
\end{abstract}

\title{
Suportes sociais
}

A mãe de K. se revelou pouco flexível para promover uma reestruturação do núcleo familiar constituído por ela e seus filhos, com dificuldades para exercer plenamente a função materna, ao oferecer a K. apoio para que ela enfrentasse seu luto e propiciar-lhe os cuidados de que ela precisava, talvez implicada com seu próprio luto e sua imaturidade (por ter sido mãe muito nova):

\footnotetext{
"Aí, voltei a morar com minha avó... Ainda falei - de brincadeira, né? - falei pra eles dois, pro L. e pro C. [seus dois irmãos], porque a B. ainda é pequena, né? Aí, falei assim: 'L., vamos fingir que a gente vai morar com a avó N., pra ver se a mãe se assusta e fica normal e cuida mais da gente.' Aí, ele falou 'tá bom', mas só que o C., não; ele é muito apegado à minha mãe, ele não quis. E o $C$. é muito bagunceiro, e minha avó já não agüenta mais essas coisas, né?"
}

\section{Outros}

\section{A experiência com os rituais de luto}

A família de K. é evangélica e, por isso, os rituais de funeral de seu pai foram restritos. No entanto, como K. só soube da morte do pai dias depois de sua ocorrência, ela não teve oportunidade de ir ao enterro, o que, durante a entrevista, a princípio, ela lamentou, por 
desejar vê-lo ainda uma vez, mas depois demonstrou não estar tão certa do que gostaria de ter feito.

\begin{abstract}
“E, no enterro, eu não lembro se eu já sabia ou não. Só que eu não fui... Não. Tenho certeza de que eu não fui. Mas eu não lembro se eu já sabia ou não... É... Ah, tem vezes que eu fico pensando que eu queria ver ele pela última vez, sabe? Mas eu não sei, eu queria ter ido, sinceramente. Eu acho..."
\end{abstract}

\title{
Expressão de vivências relativas à perda e ao processo de luto
}

Apesar de ter recebido apoio de seus familiares, que procuravam estar por perto para confortá-la, ela não foi acolhida de modo a poder expressar seus sentimentos livremente, legitimando-os, o que também pode ter lhe dificultado a vivência e a elaboração de seu luto.

\begin{abstract}
"No começo eu pensava 'ah, que idiota, né? eu que 'tô sentindo, né?como é que eu vou parar de chorar?' [...] Não, nunca tive [referindo-se à liberdade para se expressar pela morte do pai]. De chorar... que nem hoje, quando eu vejo que vou chorar, eu saio pára, pára; na hora, eu disfarço e saio."
\end{abstract}

\section{Vitimização}

Outro fator que pode ter dificultado a K. o enfrentamento de sua perda é o fato de ter sido muitas vezes tratada como alguém que precisava de cuidados diferenciados, devido à perda que sofreu, concepção fomentada por seus avós e que pode ter lhe sinalizado seu despreparo para enfrentar a vida e, em particular, a perda de seu pai:

"Com três filhos, grávida de um, imagina... Eu não sei se eu ia agüentar, sei lá. Tanto que, quando ela apronta alguma, minha avó e meu avô são os primeiros a defender. Defendem assim, falam que os meus tios têm ciúme, porque eles acham que meu avô e minha avó ajudam mais a minha mãe do que eles, e todo mundo tem ciúme... Aí, eles pegam e falam que não, que eles têm que entender que ela ficou viúva, que a gente não tem pai. Sempre falam isso, sabe? Essa é a desculpa dos meus avós, por eles ajudarem mais minha mãe." 


\title{
Fatores de proteção (apoio) para luto complicado
}

\section{Suportes sociais}

A mãe de K. não demonstrou condições para se reorganizar depois da morte do marido e exercer plenamente sua função materna, mas sua família se revelou muito unida e prestativa a ponto de K. ter feito muitas alusões a um e outro membro da família de sua mãe (tias, prima da mãe, avós maternos), com quem ela pôde contar para ser confortada e cuidada, principalmente seus avós maternos, que sempre atuaram quase que como pais dela. No entanto, como já foi dito, nem sempre essas pessoas puderam acolhê-la da forma mais adequada, de acordo com as necessidades dela:

\begin{abstract}
"Ah, bastante, da minha família, porque, como eu era pequenininha, eu não queria que ninguém soubesse, lembra que eu falei? Mas, da minha família, todo mundo... Ah, me abraçavam, falavam que, se eu chorasse, ele ia ficar triste, que eu tinha que fazer as coisas para ele ficar feliz, que ele ia estar sempre me vendo. Essas coisas..."

"Acho que você precisa de alguém pra... E, na minha avó, não, sempre tive tudo que eu quis - acho que fui até mal acostumada."
\end{abstract}

\section{Outros}

\section{Condições socioeconômicas}

Por fim, não se pode deixar de mencionar que o suporte financeiro recebido pela jovem e sua família - do Estado (pensão) e de seus avós maternos - permitiu a manutenção de um padrão socioeconômico próximo ao que a família tinha antes da morte de seu provedor, evitando perdas materiais que poderiam gerar repercussões negativas e mais estresse:

"Recebe. Mas a minha mãe falou que, se ele tivesse morrido em serviço mesmo, a pensão era maior; mas, como foi bico, é só isso daí. E a minha mãe, quando casou, ela perdeu a dela, e a dela era bem maior que a nossa. Ela falou que a nossa não é muito, não, é bem pouca. E a gente recebe... eu recebo até quando eu casar. Como a advogada estava falando pra ela, que ela 'tava vendo lá. E os meus irmãos, só até os 18. Mas não é muito, não. E o da minha mãe perdeu, porque ela casou, né? E a escola, quando a minha mãe casou, também tiraram a nossa bolsa. Aí, só tem $70 \%$ de bolsa." 
"Na verdade, minha avó e meu avô sempre ajudaram, sempre, sempre, sempre, até hoje. Minha precisa de alguma coisa? É lá que ela vai.... E, como ela vai, recebe a pensão do meu pai - ela não recebe tudo, mas ela recebe a minha, essas coisas, acaba ficando pra ela, que a gente é pequeno, tudo. E mesmo agora, que eu fiz 18, eles separam, mas eu não quis, eu deixei com ela, né? Aí, tem isso - ela recebe isso, e o meu avô sempre ajuda ela."

\title{
Crença em vida após a morte
}

Apesar de serem evangélicos, que nem sempre acreditam em vida depois da morte, $\mathrm{K}$. mencionou essa crença em situações em que se procurava consolá-la e convencê-la a parar de chorar e a voltar a comer:

\begin{abstract}
"Aí, uma prima da minha mãe também falou que, se eu tô chorando, ele tá lá em cima, feliz, e tem que... E quer me ver feliz também."
\end{abstract}

\section{Estratégias de enfrentamento}

Quando questionada sobre suas estratégias de enfrentamento de sua perda, K. respondeu que fica triste quando pensa na morte do pai, mas acrescentou que, nessas ocasiões, procura se consolar apegando-se às boas lembranças que tem dele. Entretanto, em outro momento da entrevista, ela disse que não sabe o que fez para se recuperar dessa perda, afirmando que não fez nada e concluindo que não sabia responder a essa pergunta:

\footnotetext{
"Ah, triste, né? Eu tenho uma boneca... Porque, uns dias antes de ele morrer, eu tinha pedido pra ele, aí ele me deu. Mas foi uns dias, mesmo... Acho que ele me deu no dia, talvez... Ele morreu à noite, porque, como eu era pequena, eu não lembro direito os dias que aconteceu, mas eu acho que foi bem pertinho... Aí, eu tenho até hoje... Não gosto que ninguém pegue a boneca, sabe? Tenho foto, essas coisas, pode ver fita dele. Tem bastante fita, porque, como a gente ia pra praia no ano novo, tem bastante fita com ele, lá... Ele é a cara do meu irmão, o que não conheceu ele."
} 


\section{Repercussões da perda para o adolescente e seu desenvolvimento}

\section{Sua representação de si mesma}

K. se acha chorona, sentindo-se ameaçada com a possibilidade da morte de seus entes queridos, ansiosa quanto à manutenção ou o rompimento dessas relações, ao mesmo tempo em que demonstra insegurança sobre o que sente e percebe, muitas vezes adotando concepções e posturas incoerentes com a realidade que vivencia, desqualificando-se:

"Eu sou muito chorona, né? Acho que não, que é mais agora. Tanto que, quando... Que, qualquer coisa, eu choro; tudo, eu choro. Mas sei lá, né?"

"Também que... não quando o meu pai morreu, mas depois que o pai do meu namorado morreu, eu fico pensando 'o meu pai, o pai dele, por quê?' E também eu pensei assim, toda vez que eu saio de casa, eu dou beijinho na minha avó, no meu avô, pois, a qualquer hora, pode ir alguém, sabe?"

"Acho que sim... Acho que não, que é mais agora [K. explica o fato de se achar chorona]. Eu acho, eu sinto que eu sou carente. [...] de pai e de mãe [...] Mas não é assim, né? E eu não sou carente, todo mundo me dá carinho, mas tem horas que eu sinto carinho, mas eu acho que é coisa de mulher, né?"

"Você não viu que eu estava meia... aí, depois, eu até comentei com o L. [namorado]. Eu falei que eu tinha uma pergunta de amigos, não sei o quê... Aí, no mesmo dia, meus amigos vieram conversar comigo, mas eles não sabiam, né? Aí, eu falei pro L. que eu tinha que responder quantos amigos eu tinha. Aí, eu falei que só coloquei que tinha dois ou três. 'Como, você só tem dois ou três, que só tinha dois ou três? Olha à sua volta', não sei o quê... Eu sou meio dramática, sabe? Não sei como ele me agüenta. Aí, ele falou um monte, lá. Aí, eu ia pedir pra mudar pra você. Aí, falei, ah, não..."

\section{Sua representação do outro}

Em algumas situações, K. demonstra dificuldades para ter uma percepção e fazer um julgamento apropriado das pessoas, especialmente de seus pais, tendo deles uma imagem infantil, idealizada e pouco integrada:

"É horrível, horrível, horrível. Porque pai é pai, mãe é mãe, você vai sentir falta, né? A minha mãe, com tudo, com tudo, eu amo ela, e ela é a melhor mãe do mundo, sabe? Acho que é normal." 


\section{Suas representações sobre a vida e expectativas sobre seu futuro}

Além de se dar conta da vulnerabilidade e da finitude do ser humano, bem como da imprevisibilidade da morte, K. revela que sua expectativa em relação a seu papel como mãe, no futuro, é profundamente influenciada por sua história de perdas:

"'Tadinho dele, também. Ele mora com a tia, com os primos e com a avó e com os irmãos. O pai dele morreu este ano, também. E a mãe dele, o ano passado resolveu, do nada, ir morar em F., sabe? Falou que... A gente já tem exemplo em casa - eu e ele -, que a gente não quer fazer igual com nossos filhos, né? Não que elas sejam más mães - a minha mãe e a dele -, mas é que elas são meias loucas, né?"

\section{Estruturação familiar atual}

Na percepção de K., sua estrutura familiar ficou bastante abalada com a morte de seu pai, descrito por ela como uma figura presente, que se responsabilizava por ela e que, se estivesse vivo, daria a sua mãe o suporte necessário para que ela cuidasse dos filhos, o que tem sido difícil para ela fazer sem a ajuda dele. Além disso, ela reconheceu que, para sua mãe, a morte de seu pai foi muito difícil, o que talvez também tenha contribuído para que ela tenha mudado sua postura diante dos filhos:

"Ó, pra falar a verdade, eu acho que eu sinto mais falta dele agora... Não, assim... Pra ele poder ajudar minha mãe, sabe? Minha mãe é tão novinha... E ela é meio cabeçudinha, sabe?"

"Ah, isso aí, se o meu pai não tivesse [...] aí, era a minha avó, né? Já 'tava em casa. Mas a responsabilidade de pai e de mãe era dele."

“Aí eu não sei... Talvez meus irmãos não estivessem do jeito que eles estão; não que eles sejam maus - maus de pessoa -, não; mal na escola, entendeu? Acho que, daí, todo mundo pode ter problema, não precisa não ter pai. Mas não sei... L. [irmão], acho que ele anda muito solto. Ele é menino, né? Diferente de menina. A qualquer hora, ele pode conhecer um louco aí, nesse mundo doido... Não pode ser ficar tão solto assim; eu acho que o meu pai era mais... ajuda minha mãe, nisso, sabe? Eu acho, né?"

"Ela gostava muito do meu pai. Imagina, uma mulher nova, quando meu pai morreu..." 
Na verdade, em ambos os encontros, K. abordou esse assunto diversas vezes, sempre ficando muito emocionada, enfatizando sua preocupação com relação aos irmãos, que, para ela, nem sempre recebem da mãe os cuidados de que necessitam - segundo K., seria diferente, se o pai estivesse vivo. Além disso, ela parece tender a se sentir responsável pelos irmãos, até porque, como mora com os avós maternos, tem uma condição muito diferente da dos irmãos:

\begin{abstract}
"Aí, voltei a morar com minha avó. Ainda falei - de brincadeira, né? - falei pra eles dois, pro L. e pro C. [seus dois irmãos] - porque a B. ainda é pequena - assim: 'L., vamos fingir que a gente vai morar com a avó N., pra ver se a mãe se assusta e fica normal e cuida mais da gente.' Aí, ele falou 'tá bom', mas só que o C., não. Ele é muito apegado à minha mãe - ele não quis. E o C. é muito bagunceiro, e minha avó já não agüenta mais essas coisas, né?"
\end{abstract}

Também se observa uma certa inversão de papéis entre K. e sua mãe, pois a jovem muitas vezes se coloca como responsável pelos irmãos, precisando empenhar-se para não assumir esse compromisso, e estabelece com a mãe uma relação de "amiga", caracterizada pela assimetria e pelo fato de a mãe ser pouco atuante quando K. ou os irmãos precisam de maior respaldo:

"Eu e minha mãe sempre fomos amigas. Não sei. Tanto que ela sabe de tudo da minha vida. Mas mudou [depois da morte de seu pai] Eu acho que normal."

“[...] não que ela seja má mãe, sabe? Mas ela não tem... Não é que ela não tem preocupação, não sei dizer, não sei - é meio cabeçudinha. Não sei, ela tem preocupação, tanto que meu irmão brigou aqui na escola, o mais velho, aí ela me ligou, pra eu ajudar o meu irmão, porque podem querer bater nele, entende?"

"A minha mãe falou pra mim até perguntar pra minha tia [sobre a controvérsia que envolve a morte do pai], mas eu não tenho coragem, depois de tanto tempo. Minha mãe falou 'que não é depois de tanto tempo, é que agora você está grande'. Mas eu não tenho coragem."

Na verdade, depois da morte de seu pai, a estrutura da família de K. mudou, mas não logrou uma organização que suprisse a falta do pai. Primeiro, a mãe assumiu uma postura juvenil - dois anos depois de ter ficado viúva, passou a sair com freqüência, muitas vezes sem dispensar aos filhos os cuidados necessários. 
Nessa época, inclusive, ela engravidou de uma menina, B., irmã caçula de K., que ignora quem é seu pai: "Ela ficou rebelde, depois de uns dois anos, mais ou menos, ela ficou meio rebelde. [...] Não é filha do meu padrasto. É de um cara aí, que nem a B. sabe. Eu sei, minhas tias sabem, tudo, mas a minha mãe não quer falar pra ela, sabe?"

Dois anos depois do nascimento da caçula, também durante suas saídas, a mãe de K. conheceu seu atual marido, que, entretanto, dois anos depois do casamento, foi trabalhar no Japão, onde está até hoje (já faz quase quatro anos que ele está lá), embora sempre em contato com a família de K.:

"A B. era pequenininha... Vai fazer 8. Eu acho que, quando a B. tinha uns 2 anos, minha mãe casou, vai. Entendeu? É mais ou menos isso, 7 anos. Dá certinho: eu estava na $4^{\mathrm{a}}$ série $-5^{\mathrm{a}}, 6^{\mathrm{a}}, 7^{\mathrm{a}}$, $8^{\mathrm{a}}, 1^{\mathrm{o}}, 2^{\mathrm{o}}, 3^{\mathrm{o}}-4^{\mathrm{a}}$ série, 11 anos."

"Ah, ele é bonzinho, só que, infelizmente, ele foi pro Japão, que ele falou que queria sustentar meus irmãos, tudo. Ele é mestiço, ele foi lá pra trabalhar."

"Foi, daí minha mãe só pôde ir depois de um ano. Só que ela foi indo, foi indo, e até hoje ela não foi. Ele mandava dinheiro pra ela, ele sempre mandou dinheiro para ela, sabe? E tem fim de ano que ele vem pra cá. Aí, todo mês, ele manda o dinheiro. E ele escreve pela internet, essas coisas."

Cumpre ressaltar que, desde o início da entrevista, ficou evidente que, mesmo antes da morte de seu pai, já havia uma certa confusão na família quanto aos papéis que cada um dos membros exercia na dinâmica familiar:

"Não, criou, entendeu? Só que era tudo no mesmo quintal, que nem aconteceu comigo - minha mãe e minha avó que me criaram, sabe? Não é que não criaram, criaram. Aí, tinha outra coisa: eu pedia pra sair pra minha avó - eu falo avó, mas é tia da minha mãe -, aí, ela não deixava; aí, eu pedia pra minha avó [referindose à avó biológica], primeiro; aí, ela deixava. É uma confusão.”

\section{Avaliação da entrevista}

Quando se perguntou a K. o que a levou a aceitar participar deste estudo, ela disse que ficou feliz em ser escolhida, com tantos outros órfãos na escola, de um modo que indicou que ela se sentiu privilegiada, especial. 
"Eu fiquei feliz de ter sido escolhida... São tantos órfãos nesta escola, né? Escolheram eu... não sei..."

Entretanto, ela revelou que temia não conseguir responder às perguntas que lhe seriam feitas, explicando que há momentos em que ela não sabe explicar o que sente e contando que, tanto no questionário quanto na entrevista, não soube responder a muitas das perguntas:

"Eu fiquei com medo de não saber responder..."

Em relação a como se sentiu durante os encontros com a pesquisadora, K. disse que, da primeira vez, quando respondeu ao YSR, sentiu-se envergonhada e chegou a chorar um pouco. Entretanto, no segundo encontro, na entrevista, ela ficou à vontade e conseguiu expressar suas idéias e sentimentos sobre o que lhe era perguntado, apesar de seu temor de não conseguir responder às perguntas, o que, segundo ela, de fato aconteceu em vários momentos:

“À vontade. Na primeira vez, eu fiquei com vergonha, né? Até chorei, na primeira vez. Mas, não, foi tranqüilo. Falei tudo o que eu sentia - que eu posso sentir, também, né? Porque tem hora que eu não sabia..."

\section{V.1.2 Caso J.}

\section{Características do adolescente e de sua perda}

\section{Apresentando J.}

Quando participou desta pesquisa, J. tinha 18 anos, cursava o $3^{\circ}$ ano do ensino médio, pela manhã, e, à tarde, fazia um curso de computação, preparando-se para prestar vestibular para ciência da computação.

J. estudava nessa escola desde pequeno e disse que gostava muito de lá, contando também que quase todos os seus amigos eram dessa escola, pois, no bairro onde ele morava, filhos de policiais não eram bem-vistos, o que lhe dificultava relacionar-se com a vizinhança. Entretanto, tem muitos amigos e é muito popular na escola, embora nunca tenha tido uma namorada. 
Atualmente, J. mora com a mãe (44 anos) e a irmã (24 anos), que, na época da pesquisa, irmã trabalhava num hospital da rede pública, depois de ter sido aprovada em concurso na área, e cursava o último ano de enfermagem numa universidade particular.

Os pais de J. eram casados e, quando da morte do pai, a mãe se afastou do cargo que exercia até então no serviço público e, com o tempo, aposentou-se, devido à depressão que a acometeu depois da perda do companheiro, não voltando mais a trabalhar.

J. contou que, assim que concluir o ensino médio, pretende prestar concurso público, para começar a trabalhar e poder pagar seus estudos, seguindo o exemplo da irmã, pois não quer ficar dependendo para sempre da mãe.

Durante a entrevista, ele se mostrou bastante empenhado em cooperar, adotando uma postura que indicava segurança, objetividade e seriedade, apesar de seu discurso ter sido, em alguns momentos, contraditório e revelar pouco colorido emocional.

\section{Sua perda: a história de $\mathbf{J}$.}

Há cerca de 15 anos, quando J. tinha de 3 para 4 anos de idade, seu pai, que na época contava com 44 anos, foi assassinado, em serviço, enquanto fazia policiamento, no cumprimento do dever. Como era muito pequeno, o jovem não tem muitas lembranças do fato, mas contou que, na época, sua mãe ficou muito mal e deprimida, ao passo que sua irmã, que ele sempre reputou muito forte, apesar de também ter ficado mal e só ter 10 anos de idade, "conseguiu ficar no controle da situação".

J. relatou que, quando seu pai morreu, ele e sua família não puderam contar muito com o apoio de parentes, pois a família da mãe morava em outro estado e a do pai não era nada próxima da dele.

Segundo o jovem, desde pequeno ele já sabia que o pai tinha morrido e, por isso, essa morte não foi um choque para ele, mas ele reconheceu que só teve verdadeiramente noção do que tinha acontecido com seu pai e sua família por volta dos 10 anos de idade, quando começou a pensar no que essa morte significava.

Quando realmente se deu conta do que tinha acontecido, J. ficou chateado, triste e imaginando como seria sua vida se o pai estivesse vivo e, apesar de entender que, cedo ou tarde, todo mundo vai morrer, ele se perguntava, por um tempo, o porquê de isso ter acontecido com ele.

O jovem também mencionou que, quando soube que o assassino havia morrido, ele quis saber se era verdade, querendo entender o que levava alguém a tirar a vida de outra 
pessoa, embora, para ele, a morte do assassino de seu pai não fizesse diferença, pois ele considerava que não tinha o direito de julgá-lo.

J. acredita ter sido corretamente informado sobre as circunstâncias da morte de seu pai e que não haveria motivo para que algum fato the tivesse sido omitido, mas também comentou que às vezes pensa na possibilidade de seu pai ter sido assassinado por outro policial e que houve comentários de que teria sido um crime encomendado.

Também por ele ser muito pequeno quando o pai morreu, sua mãe não permitiu que ele participasse de nenhum dos rituais dos funerais, o que não o aborreceu, porque ele acha essas situações muito desagradáveis.

Sobre seu relacionamento com o pai, J. pouco pôde dizer, por não ter convivido muito tempo com ele, mas seu discurso parece indicar que o pai era uma figura atuante no âmbito familiar e que, ao morrer, tornou-se para J. um "herói" e passou a exercer sobre ele uma grande influência.

\section{Vivências e manifestações relativas à perda e ao processo de luto do jovem}

\section{Reações imediatas}

J. não se lembra de ter tido alguma reação na ocasião, de modo que, em sua percepção, é como se ele sempre tivesse sabido da morte de seu pai, embora reconheça que só aos 7 anos tenha começado a pensar sobre isso, mas só pelos 9, 10 é que ele pôde de fato entender o que isso significava:

\footnotetext{
"Não, assim, lembrar, não; mas desde pequeno eu já sabia, né? Desde pequeno [...] via falando assim, pra mim "seu pai...". Desde pequeno; eu não tive um choque grande, porque parece que eu já sabia, mesmo tendo uma idade menor, parece que eu já estava sabendo. E não tinha noção. Se eu ficasse sabendo mais ou menos, com $7 \ldots$ entre 6 e 7 anos, aí até que eu ia lembrar $[\ldots]$ ficar chateado, como eu reagi... Naquela época, a minha reação... Era muito pequeno para ter noção."
}

\section{Vivências e manifestações subseqüentes}

Como já foi dito, a primeira vez que J. pensou sobre a morte de seu pai ele tinha 7 anos, mas só começou a se dar conta do significado dessa perda aos 9 ou 10 anos, quando foi assolado por vivências e manifestações decorrentes dessa percepção: 
"Eu tava com 7 [...] Quando dei conta, mais ou menos eu tinha de 9 para 10 , já estava crescendo, não estava..."

"Eu me dei conta, depois de um tempo, que realmente eu tinha perdido meu pai e, às vezes, até me perguntava por quê. Por que eu perdi meu pai? Aí, foi indo, eu fui entendendo; policial, até hoje, às vezes, as pessoas me perguntam se vai ser policial ou não; às vezes, até dou conselho pra falar que policiamento não dá dinheiro, você pensa que vida de policial tem tudo - pode até ser, mas é corrupto, policial não ganha muito bem [...] eu acho que não vale a pena [...]. Aí, eu fiquei assim... tempo que eu ficava triste, poderia imaginar como seria a vida, se ele estivesse vivo hoje, talvez se ele ia gostar do jeito que eu sou, do jeito que eu ajo, com uma tarefa, me dou com alguns problemas, ver se ia ele ia ter orgulho de mim, realmente."

"Olha, eu ficava triste. Às vezes, não dava vontade de fazer algumas coisas, mas, aí, eu tinha e tenho até hoje, eu vou procurar ser pros meus filhos o que eu não tive. Eu vou procurar ser um pai atencioso, o que for possível, o que eu puder fazer eu vou fazer, porque eu não tive. Eu fiquei triste, sim, mas aí eu tenho que entender que todo mundo um dia vai morrer, mais cedo ou mais tarde."

\section{Vivências e manifestações atuais}

Hoje, J. reconhece que ainda há momentos em que ele se entristece com a morte do pai e fica tomado pelo desânimo, sem vontade de fazer nada, mas ele tem consciência de que não há como mudar a realidade e, nessas ocasiões, procura se distrair, para não ficar pensando no pai e em sua morte:

\footnotetext{
“Hoje, pra mim, não vou falar que [não] 'tá melhor, mas não 'tá cem por cento. Às vezes, até dá vontade de eu sair com ele; sonhava fazer algumas coisas, mas aí... eu tenho consciência que... já era, não tem como voltar atrás. Eu procuro me distrair, conversar, quando eu quero, às vezes, não só o fato de ele ter falecido [...] outros fatos, também. Procuro me distrair, saindo, às vezes, entre aspas, para zoar um pouco, fazer alguma coisa que me distraia."
}

\section{Fatores de risco (vulnerabilidade) para luto complicado}

\section{Fatores predisponentes no enlutado e de sua relação com o falecido pai}

O fato de J. ter ficado órfão na infância o predispõe para o luto complicado, especialmente por essa perda ter ocorrido antes de ele completar 5 anos de idade (Bromberg, 
2000). Além disso, a relação de J. com o falecido por ocasião de sua morte era de grande dependência, não só pela natureza desse vínculo e pela idade do menino, mas sobretudo porque seu pai era uma figura participativa no âmbito familiar e que assumia a função paterna de modo atuante:

"Ele ia na feira, um exemplo, ele gostava... pegava as melhores frutas pra levar pra mãe dele e pra minha mãe, na casa da minha avó. Pegava tudo que era melhor; ele comprava assim: pegava na loja, pra minha irmã, ele mandava ela escolher a boneca."

\section{Fatores relativos à perda $\mathrm{em}$ si}

O pai de J. foi assassinado por um marginal, morte que se caracteriza como súbita e violenta, cenário que por si só constitui fator de risco para luto complicado, ainda mais quando se considera que, apesar de as circunstâncias que cercaram essa morte terem sido aparentemente esclarecidas, J. mencionou questões sobre esse evento que o acompanham até hoje:

\footnotetext{
“Ah, sim, acho que sim, é uma maneira muito trágica, né? Se fosse um acidente... se ele caísse de algum lugar, seria... mesmo assim, não seria menos doloroso, mas até que podia aceitar; agora, alguém chegar e tirar a vida dele, isso... ninguém poderia..."
}

"Não consigo entender porque o ser humano tira a vida de uma outra pessoa... o ser humano... por inveja ou por bem material, que seria roubo, né? Seria alguma coisa assim. Não entendo essa vontade de ter... 'tá certo, ter sempre mais, mas agir... com a sua própria capacidade, não querer tirar dos outros pra ter... ter proveito disso..."

"Dúvida, não, dúvida, não. Me falam que o assassino morreu, mas eu queria saber se realmente morreu, sei lá, pra ver se ele fez... tirar a vida de uma pessoa... não é certo."

"Eu acho que não... Pra mim, foi esclarecido tudo, sobre o assassinato, também não tem por que esconder alguma coisa. Sabe, eu não sei, falam que... não gostavam dele porque ele era uma pessoa na dele. Ele via muitas coisas e não dava opinião; se foi outro policial, algum outro, mandando, muitas pessoas falam que mandaram..." 


\section{Suportes sociais}

J. não recebeu muito apoio da família na época da morte de seu pai, pois sua mãe ficou muito mal, com depressão, a ponto de ser afastada definitivamente do trabalho, enquanto sua irmã mais velha - referência para J. e que, segundo ele, "foi durona" - era muito nova para poder dar a ele o devido suporte, pois ela só tinha 10 anos de idade.

Além disso, a família da mãe de J. sempre viveu em outro estado e só pôde dar algum apoio por telefone, e a família do pai nunca teve um relacionamento próximo com a de J. e na ocasião, não se conduziu de outro modo, com exceção de um tio de J., irmão de seu pai:

\footnotetext{
"Bom, minha mãe - lógico, né? - ficou muito sentida (...) afastamento do serviço. Agora, já a minha irmã, minha irmã sempre foi forte. Sempre foi... durona, assim. Pelo que eu sei, a reação dela foi, foi muito... ruim, mas, ao mesmo tempo, ela pensava na minha mãe, porque, se ela ficasse também deprimida, ia acabar [...] família, aí, ia ser pior. Ela conseguiu manter o controle da situação."

"Pelo que eu sei, esse tio meu [...] que mora no centro... que eu tenho mais contato, que ajudou. Agora, os outros, não muito. Eles também são um pouco distantes um do outro."

"É, não tinha como eles virem pra cá. Os parentes da minha mãe, virem pra cá. Eles deram apoio, se não foi por telefone, só foi por telefone mesmo, porque, pra cá...”

"Até que teve um apoio familiar; pouco, mas teve... Criança... meu tio, né? Apoiou a minha família inteira, na época."
}

\section{Outros}

\section{Expressão de vivências relativas à perda e ao processo de luto}

Apesar de, na época da morte de seu pai, J. ter recebido algum apoio de um de seus tios paternos, que percebeu sua tristeza e procurou conversar com ele sobre sua perda, ele contou que, por ser criança, não se sentiu no direito de perguntar muito sobre o que estava acontecendo. E, mesmo depois, já adolescente, em determinadas situações, preferiu calar-se, evitando expor o que pensava e o que sentia, o que pode ter lhe dificultado o reconhecimento e a legitimação de sua dor: 
"Se mostrei, não foi muito, foi pouca coisa, não foi muito, não... Meu tio, mesmo, meu tio percebeu... Não, aquelas histórias de ver que... perdi meu pai, não sei o quê... Porque era criança, não podia pergunta tudo... Ouvia, falava... Não, não, fiquei na minha, mesmo. Eu sempre fui na minha, assim, quieto - quieto entre aspas, quieto para algumas coisas... Tive, sim, mas... algumas coisas eu nem converso, prefiro. Prefiro, sei lá, já aconteceu [...] sobre o passado, eu nem converso."

\section{Fatores de proteção (apoio) para o luto complicado}

\section{Suportes sociais}

J. relatou que, na época da morte de seu pai, ele e sua família puderam contar com algum apoio de um tio, irmão do pai. Mais tarde, quando o jovem se deu realmente conta de sua perda, foi esse tio quem ofereceu algum suporte para sua dor, apesar de nunca ter sido exatamente próximo de J. e de sua família:

"Até que teve um apoio familiar; pouco, mas teve. Pelo que eu sei, esse tio meu, que mora no centro [...] que eu tenho mais contato, que ajudou. Criança [...] meu tio, né? Apoiou a minha família inteira. Assim, meu tio mesmo, meu tio percebeu [minha tristeza]... Ouvia, falava... [o tio, ao apoiá-lo]."

\section{Outros}

\section{A experiência com os rituais de luto}

J. não foi ao velório ou ao enterro do pai porque sua mãe achou que ele era muito pequeno para participar desses rituais, e ele vê essa decisão como positiva, porque acha que esses rituais são experiências desagradáveis e que não têm muito significado para ele. Nesse sentido, ele disse que:

"Eu não fico muito chateado por não ter ido ao velório, porque é uma coisa muito desagradável; eu fico chateado por ter perdido [o pai], agora, por não ter ido ao velório, até que eu não tenho muita preocupação. É uma situação muito desagradável." 


\title{
Condições socioeconômicas
}

O fato de J. e sua família terem contado com suporte financeiro, quer pela pensão do pai, quer pela aposentadoria da mãe, permitiu-lhes manterem um padrão socioeconômico próximo ao que tinham antes da morte do pai, evitando perdas materiais, que poderiam ter acarretado para a família outros problemas:

"Bom, acho que não. Se houve uma perda, minha mãe conseguiu tomar controle da situação, porque... eu tenho direito a colégio pago, a minha irmã estudou também em colégio pago [...] se teve um abalo financeiro, minha mãe correu atrás, pra brigar..."

\section{Crença em vida após a morte}

Apesar de ter se mostrado um pouco confuso e pouco convicto quanto a acreditar na existência de vida após a morte, J. disse que se for para o céu e seu pai estiver lá será muito bom, embora não tenha deixado claro se esta expectativa o ajudou de alguma forma a enfrentar a morte de seu pai:

\begin{abstract}
"Tem tantas religiões - um fala uma coisa, outro fala outra -, que eu fico até meio confuso. Antes, eu acreditava. Purgatório, ou vai pro purgatório, aí, gente que vai pro céu ou pro inferno. Hoje, eu estou até meio confuso, mas eu acredito ainda em vida depois da morte. Assim, não, não. Eu não sei nem se eu vou para o céu brincadeira -, mas eu não fico contando com essa, não, porque às vezes é até um pouco de ilusão acreditar nisso. Eu acredito, sim, mas não boto muita fé; eu tenho uma certa desconfiança. Mas, se eu for pro céu e ele estiver lá, vai ser uma felicidade, né?"
\end{abstract}

\section{Presença de figuras substitutivas}

Apesar de ter ficado deprimida depois da morte do marido e de não ter conseguido dar o devido suporte a J. com relação a sua perda, com o tempo, sua mãe se recuperou e pôde reorganizar a estrutura familiar, passando a representar, para o filho, uma figura substitutiva da figura paterna: "desde pequeno, ela me criou sozinha; perdi meu pai com 3 anos, vai fazer 15 anos que eu perdi meu pai; aí, ela é quem faz tudo lá em casa; ela é o homem, ela é o pai, a mãe, ao mesmo tempo." 


\title{
Presença de modelos de identificação positiva (e de proteção)
}

J. revelou sua admiração e seu reconhecimento pela irmã mais velha, que, na concepção dele, por ocasião da morte de seu pai, conseguiu manter o controle da situação e não deprimir, como sua mãe, o que, para J., teria sido a ruína da família, conforme já se mencionou anteriormente.

Além disso, quando relatou que tinha planos para o futuro que se espelhavam em estratégias já adotadas por sua irmã, deixou a impressão de ter se identificado com ela de um modo que pode tê-lo ajudado a ficar mais protegido diante de sua perda e de seu luto:

\begin{abstract}
"Tenho uma irmã que já se formou e vai se formar enfermeira no final deste ano, faz faculdade; estudou no colégio, já fez um concurso público. Ano que vem, quero ver se eu faço, eu vou tentar, vou fazer de tudo, vamos ver se eu consigo passar no concurso público..."
\end{abstract}

\section{Estratégias de enfrentamento}

J. procurou enfrentar sua perda adotando um "comportamento decente", ou seja, não se deixando abalar pela situação, buscando ocupar-se e se distrair com outros assuntos, não pensando no que acontecera a seu pai e a ele, tentando se convencer a aceitar o inevitável, pois um dia, mais cedo ou mais tarde, todo mundo morre:

"Acho que até eu tive um comportamento decente, eu não tive nenhuma crise, assim; crise, até tive, mas eu consegui levar a situação, depois que eu... Um comportamento decente é, por exemplo, não se deixar abalar por essa situação; abalou um pouco, não muito; deixar de fazer alguma coisa, assim... às vezes, não dava vontade, mas eu fazia; procurava me ocupar para não ficar lembrando muito; a minha ocupação é que é um comportamento decente. Ficava o dia inteiro em um lugar público, também."

"O mais difícil foi aceitar a morte - eu não conseguia aceitar. Eu imaginava como seria a vida com ele do lado. Mas, aí, depois, eu fui percebendo: realmente, não passa de uma ilusão, meu pensamento; me ocupava, fazia alguma coisa, saía, procurava mesmo um pouco triste - conversava sobre outros assuntos, às vezes acabava soltando uma risada..."

"Eu fiquei triste, sim, mas, aí, eu tenho que entender que todo mundo um dia vai morrer, mais cedo ou mais tarde." 


\section{Repercussões da perda para o adolescente e seu desenvolvimento}

\section{Representações sobre si próprio}

A morte de seu pai por assassinato foi um marco a partir do qual o pai tornou-se para J. uma figura idealizada e um modelo a seguir - segundo suas próprias palavras, um "herói" -, estratégia que ele também parece adotado para o enfrentamento dessa perda e sugere que tenha assumido uma postura rígida diante da vida, ao se agarrar à necessidade de ser como era seu pai:

\footnotetext{
"Espero que as pessoas consigam entender; por exemplo, quem perdeu um pai, que seja do jeito que queria que ele fosse, né?"

"Eu lembro, assim, um herói. Ele fez bastante coisas boas: ajudou pessoas, foi uma pessoa decente. Às vezes, ele também não falava o que ele ia fazer, eu também não falo.”

"Não, aí, depois, eu consegui me erguer; consegui... aí, eu, até hoje, sempre tenho um pensamento - não, eu vou ser parecido, eu vou procurar $[\ldots]$ como eu já tinha dito."
}

Mas J. também relatou que, às vezes, não consegue ser como imagina que o pai era (ou seria) ou gostaria que ele fosse e ele se ressente de não tê-lo por perto para se aconselhar com ele e agir de forma mais adequada:

\footnotetext{
"Poderia ser alguma - como eu posso dizer? - algumas ações diferentes, por exemplo, não toma uma decisão precipitada, como às vezes eu tomo; podia até pedir um conselho para ele. Hoje, eu faço alguma coisa sem pensar, aí eu vejo a conseqüência, se é boa ou ruim."
}

\section{Representações atuais sobre o outro e sobre a vida em geral}

O fato de seu pai ter sido assassinado parece ter contribuído para que o jovem passasse a ter uma visão desconfiada do outro e do mundo, dado o registro de imprevisibilidade e de ameaça que provavelmente deixou a tragédia:

\footnotetext{
"Assim, eu tenho uma certa desconfiança com as pessoas. Bom, pra mim, a minha opinião, assim: sei que o mundo é violento, sou desconfiado com muitas coisas; nos outros, eu tenho sempre mais desconfiança, assim..."
} 


\section{Expectativas sobre seu futuro}

A experiência de J. como filho de um homem que foi assassinado quando ele era muito pequeno e que, por isso, não pôde acompanhá-lo em sua infância e juventude influenciou-o significativamente quanto a como ele deve se conduzir no futuro, como pai: "mas, aí, eu tinha - e tenho até hoje -, eu vou procurar ser, pros meus filhos, o que eu não tive. Eu vou procurar ser um pai atencioso, o que for possível; o que eu puder fazer, eu vou fazer, porque eu não tive." Além disso, de modo geral, J. parece bastante exigente quanto à conduta que assume, na expectativa de que em seu futuro sua vida possa atender a um padrão que em seu entendimento agradaria a seu pai, se ele estivesse vivo:

"Bom, a respeito do meu futuro, acho que vou procurar tentar ser o melhor, para dar muito orgulho pra ele, lá onde ele estiver. Agora, assim, após... o meu jeito de agir, o meu jeito de pensar, acho que não mudou, não. Mesmo que ele estivesse vivo, eu teria meu jeito, acho que não iria mudar, já nasci do jeito que eu sou, assim..."

\section{Estruturação familiar atual}

Após a morte do pai, a família se desorganizou por algum tempo, pois a mãe deprimiu a ponto de ser definitivamente afastada do trabalho, mas, na percepção de J., sua irmã, mesmo só tendo na época 10 anos de idade, manteve "o controle da situação", o que parece ter representado para ele um grande alívio.

Anos depois, aos 7 anos, ele começou a perceber o que se passara e se deu conta de que sua mãe tinha ficado muito mal, mas só aos 10 é que de fato ficou mais claro para ele o que acontecera, quando, segundo ele, sua mãe já estava melhor e ele não poderia fazer mais nada por ela. Ou seja, de algum modo, sua mãe se recuperou a ponto de promover alguma reestruturação familiar, ao se tornar "o homem, o pai e a mãe", contribuindo para que os filhos também se reorganizassem:

"Bom, minha mãe - lógico, né? - ficou muito sentida [...] afastamento do serviço. Agora, já a minha irmã, minha irmã sempre foi forte. Sempre foi... durona, assim. Pelo que eu sei, a reação dela foi, foi muito... ruim, mas, ao mesmo tempo, ela pensava na minha mãe, porque, se ela ficasse também deprimida, ia acabar [...] a família, aí, ia ser pior. Ela conseguiu manter o controle da situação." 
"Pra falar a verdade, quando eu percebi, já era tarde demais. Eu 'tava com 7 [...] Quando me dei conta, mais ou menos eu tinha de 9 para 10, já estava crescendo, não 'tava... ela entendeu, e foi seguindo a nossa vida normal."

"Os muitos gastos que ela tem comigo... desde pequeno, ela me criou sozinha; perdi meu pai com 3 anos, vai fazer 15 anos que eu perdi meu pai; aí, ela é quem faz tudo lá em casa; ela é o homem, ela é o pai, a mãe, ao mesmo tempo."

Porém, às vezes, ele sente falta do pai, como alguém do mesmo sexo que ele e que, por isso, pudesse entendê-lo melhor em algumas de suas necessidades, para que ele pudesse conversar, trocar idéias, talvez, aconselhar-se: "Aflige; às vezes, eu quero conversar... algumas coisas... só eu sei, ou assunto de homem, né?"

\section{Avaliação da entrevista}

Não foi a primeira vez que J. foi entrevistado por uma psicóloga para falar sobre a morte de seu pai, pois, na escola em que estuda, os psicólogos escolares fazem acompanhamento dos órfãos, tendo em vista seu desempenho escolar, e ele já tinha sido entrevistado duas vezes por essa equipe.

Acrescentou que não se sentiu constrangido de falar sobre esse assunto novamente, já que seu pai já morreu há muito tempo e ele acredita que sua experiência pode ajudar outros jovens que se encontram na mesma situação que ele:

"Então, já faz 14, 15 anos, por aí, que ele faleceu que, qualquer coisa que me perguntar, eu vou responder sem nenhum constrangimento."

"Ah, eu resolvi conversar também; daí, eu espero que sirva pra alguma coisa essa entrevista, que outras pessoas possam ouvir, se tiver [...] entre aspas, problema, conseguir vencer, porque não é fácil, mas tem que vencer, porque viver só do passado não será possível." 


\section{V.1.3 Caso R.}

\section{Características do adolescente e de sua perda}

\section{Apresentando R.}

R. é um jovem que tinha 16 anos quando se realizou esta pesquisa, cursava o $2^{\circ}$ ano do ensino médio e morava com a mãe, de 44 anos, seu irmão, de 19, e sua irmã, de 10, que estudavam na mesma escola que ele.

Os pais de R. eram casados e, depois da morte do pai, a família continuou na mesma casa em que morava antes, passando a viver da pensão que ele deixou. Há cerca de um ano, a mãe de R. começou a trabalhar como comerciária.

Ele tem muitos amigos, nunca namorou e, três vezes por semana, freqüenta uma escolinha de futebol, enfatizando seu interesse por esportes, especialmente futebol.

No contato, R. se mostrou reservado, nem sempre conseguindo responder ao que lhe era perguntado ou respondendo de modo lacônico ou pouco claro, com dificuldades para se expressar e revelar seus sentimentos.

Entretanto, deve-se ressaltar que, no dia em que R. respondeu ao questionário e fez a primeira entrevista, ele tinha perdido a hora da aula, mas foi à escola e ficou esperando um bom tempo pela chegada da pesquisadora, só para participar deste estudo, o que parece indicar que houve da parte dele disposição nesse sentido.

\section{Sua perda: a história de $\mathbf{R}$.}

Cerca de quatro anos atrás, quando tinha 11 anos, R. perdeu seu pai de forma bastante trágica, num episódio que, na época, foi muito comentado na mídia, por envolver uma proeminente figura política.

Seu pai foi assassinado a tiros enquanto fazia a segurança de um familiar desse político, mas a autoria e a motivação desse crime permaneceram desconhecidas, apesar das inúmeras especulações que foram então levantadas.

Entretanto, durante a entrevista, o jovem disse que a autoria desse crime tinha sido atribuída a um conhecido grupo do crime organizado, embora ele tenha alegado que tivesse dúvidas a respeito da veracidade dessa informação, apesar de não ter nenhuma outra explicação para o assassinato de seu pai. 
O jovem contou que, na noite em que seu pai morreu, sua mãe foi imediatamente notificada, tendo chegado a ir ao hospital, ter com seu pai, enquanto ele e seus irmãos eram informados do que se passava por um tio, marido de uma irmã de seu pai.

Ele também contou que esteve no velório, embora só por pouco tempo, além de ter ido ao enterro e à missa de sétimo dia, participações que, em sua avaliação, foram importantes, embora ele não tenha conseguido justificar essa opinião, quando questionado a respeito.

Sobre seu relacionamento com o pai, R. qualificou-o de "apegado", pois, apesar de o pai trabalhar muito, ele jogava futebol com R., andava de bicicleta com ele, costumava levá-lo a passear e $\mathrm{o}$ ajudava a fazer as lições.

Quanto ao relacionamento familiar, o adolescente afirmou que o pai era próximo de todos, descrevendo sua família na época como muito unida:

"Nós fazíamos todas as coisas juntos."

\section{Vivências e manifestações relativas à perda e ao processo de luto do jovem}

\section{Reações imediatas}

R. reagiu à morte do pai ficando nervoso e chorando, sentindo-se muito triste, mas sem falar nada e procurando logo se conter.

“Ah, fiquei nervoso... Ah, fiquei só quieto, né? Chorando, aí... Chorei... Não falei nada... Chorei no dia, mesmo."

\section{Vivências e manifestações subseqüentes}

Depois que soube que seu pai tinha morrido, R. procurou se conter, sem chorar ou falar nada, mas muito triste, segundo ele, só por cerca de um mês:

"E depois, só segurando, mas não chorava. 'Tava triste. Não, durou um mês."

Ele contou também que seus irmãos também choraram, principalmente sua irmã, reação que R. parece atribuir ao fato de ela ser menor - na época, ela só tinha 6 anos. Já sua mãe só chorou no dia em que recebeu a notícia da morte do marido; depois, ela ficou "normal”, dizendo aos filhos: "Ah! Passou já, passou, passou, né? Vai viver a vida." 


\section{Vivências e manifestações atuais}

Sobre como vivencia e manifesta sua perda e seu processo de luto hoje, R. disse:

"É, fico nervoso, às vezes... Ah, às vezes, eu fico normal, mas, às vezes, eu fico... triste. É, não penso muito. É só às vezes, quando penso, fico triste, mas, às vezes, não."

\section{Fatores de risco (vulnerabilidade) para luto complicado}

\section{Fatores predisponentes no enlutado e de sua relação com seu falecido pai}

Entre os fatores que podem ter predisposto R. ao luto complicado, está a sua idade ao perder o pai (11 anos, pré-adolescente), sobretudo considerando-se a relação que eles tinham na época, de grande dependência, quer pela própria natureza desse vínculo, quer pela idade do menino ou pelo fato de o pai ser uma figura participativa na família, que assumia a função paterna de modo atuante, a ponto de R. ter descrito seu vínculo com ele como "apegado" (Bromberg, 2000).

\section{Fatores relativos à perda em si}

O pai de R. foi assassinado, o que caracteriza sua morte como súbita e violenta, condições que representam fatores de risco para luto complicado:

\footnotetext{
"Ah, eu 'tava dormindo. Aí, eu acordei, olhei pela janela e vi uma viatura. Aí, quando eu vi, meu irmão 'tava chorando. Não, não 'tava chorando, 'tava só falando - falando que meu pai tomou um tiro; só depois que falou. Meu tio, que 'tava lá. É esposo da minha tia, da irmã do meu pai. Foi que passaram atirando, passaram atirando. $\mathrm{Na}$ casa do [...] Ele era segurança do [...] Ele 'tava lá fora, esperando ele. Ele 'tava esperando, aí, passaram atirando. Aí, ele ficou um pouco lá no hospital e morreu."
} 


\section{Outros}

\section{Expressão de vivências relativas à perda e ao processo de luto}

O relato de R. demonstrou que ele não conseguiu se expressar livremente com relação à sua perda e ao seu luto, fato que ele confirmou quando questionado a respeito, justificandose: "Daí, eu ficava me lembrando dele, toda hora; aí, ficava chateado."

No dia em que soube da morte de seu pai, R. ficou nervoso, triste e chorou, mas ele mesmo afirmou que já no dia seguinte conteve-se e evitou se manifestar a respeito: "E depois, só segurando, mas não chorava."

Além disso, R. pode ter se sentido desestimulado por sua mãe - e talvez por outras pessoas próximas - a vivenciar sua perda e seu luto, pois, segundo o jovem, diante da morte do marido, a mãe mostrou-se "normal", como se nada houvesse acontecido, inclusive dizendo para os filhos: “Ah! Passou já, passou, passou, né? Vai viver a vida."

\section{Fatores de proteção (e apoio) para luto complicado}

\section{Suportes sociais}

Segundo R., na época da morte de seu pai, ele recebeu apoio de todos, familiares e amigos, que procuraram ficar perto dele, de modo que, apesar de não se falarem, R. se sentiu compreendido em sua dor: "Dos amigos, de todo mundo. Achei bom. Ficavam junto comigo, não me abandonavam. Entendiam.”

Entretanto, ele não foi capaz de dar mais detalhes sobre como se deu esse apoio e de que forma ele sabia que as pessoas o entendiam, apesar de eles não conversarem ente si: "Bem... elas ficaram... não consigo explicar. Não conversavam."

\section{Outros}

\section{A experiência com os rituais de luto}

R. reconheceu que foi importante para ele ter tido a oportunidade de participar do velório, do enterro e da missa de sétimo dia de seu pai, situações que poderiam ter contribuído para que ele constatasse e enfrentasse sua perda, mas ele não soube explicar o por que dessa importância: 
"Eu fiquei no velório; aí, foi pro enterro... Sim, fui [referindo-se à missa de sétimo dia do pai]... Devia ter ido, sim [com relação ao velório, ao enterro e à missa]. Ah, não sei, não [sobre a importância dessa participação, para ele."

\section{Condições socioeconômicas}

Quando perguntado sobre as mudanças que ocorreram em sua vida e na vida de sua família depois da morte de seu pai, R. foi muito evasivo, afirmando que nada mudara, que tudo ficou como antes, indicando sua dificuldade em se apropriar da realidade que permeou a morte do pai.

De qualquer modo, como seu pai morreu enquanto trabalhava, a família passou a receber do Estado uma pensão que correspondia a seu salário integral, o que, de alguma forma, resguardou financeiramente R. e os seus, poupando-os de situações desgastantes decorrentes da queda de poder aquisitivo.

\section{Crença em vida após a morte}

Em seu discurso, R. não só assumiu sua crença na vida após a morte, como também reconheceu que ela o ajudou a enfrentar a tristeza que sentia por ter perdido seu pai: "Ah, pra não ficar triste [referindo-se ao benefício da crença na vida depois da morte].”

\section{Estratégias de enfrentamento}

Sobre as estratégias que usou para enfrentar sua perda e seu luto, R. disse que evita pensar muito sobre o que aconteceu a seu pai, a ele e a sua família, procurando seguir em frente: "Fiquei... é... bola pra frente, né? Só isso."

\section{Repercussões da perda para o adolescente e seu desenvolvimento}

\section{Representações sobre si mesmo, o outro, a vida e expectativas sobre seu futuro}

Em seu relato, a maior parte do tempo R. defendeu a idéia de que nada mudou em sua vida após a morte de seu pai, com exceção do fato de o pai não mais acompanhá-lo ao futebol, não levá-lo mais para passear e não ajudá-lo mais nas lições. 
A postura assumida por ele durante todo o procedimento também se repetiu quando R. foi diretamente perguntado sobre as repercussões que a morte do pai teria tido em sua vida, pois, apesar de dizer que pensou muito sobre isso, não soube dizer nada sobre o que pensou, muito menos identificar quais teriam sido essas repercussões:

"Ah, pensei um monte de coisas... É, não sei explicar. Pensei muito."

\section{Estruturação familiar atual}

R. não foi capaz de revelar com clareza como sua família se reestruturou depois da morte do pai, pois a maior parte do tempo ele tendeu a defender a idéia de que nada havia mudado depois dessa morte.

A exceção a essa sua afirmação foi quando ele admitiu que teve que aprender a se virar sozinho na execução das tarefas escolares, pois seu pai não podia mais ajudá-lo:

“Às vezes, ele me ajudava na matéria. É, nas lições de casa. É, aí, tinha que me virar sozinho, agora."

Como já se disse antes, o discurso de R. faz supor que ele ainda não se deu conta das repercussões da morte de seu pai em sua vida e na de sua família, parecendo, de certa forma, alheio a sua nova realidade, pouco disponível para pensar sobre ela, provavelmente defendendo-se do sofrimento que isso pode representar para ele.

\section{Avaliação da entrevista}

Sobre sua participação neste estudo, R. disse não ter tido nenhuma impressão a respeito do convite que the foi feito e que resolveu aceitar estimulado por sua mãe, que, quando contatada pela pesquisadora, pareceu empolgada com a idéia da participação do filho:

\footnotetext{
"Nada [referindo-se ao que teria pensado a respeito do convite para participar desta pesquisa]. A minha mãe também ficou falando pra eu fazer; também, eu já ia fazer."
}

Quanto a sua vivência e a seus sentimentos durante a entrevista, ele respondeu que se sentiu "normal" e que a entrevista transcorreu conforme ele imaginara: "É isso mesmo." 


\section{V.1.4 Caso C.}

\section{Características do adolescente e de sua perda}

\section{Apresentando C.}

Por ocasião de sua participação nesta pesquisa, a jovem C. tinha 16 anos, cursava o $2^{\circ}$ ano do ensino médio, pela manhã, e, à tarde, trabalhava como operadora de caixa na farmácia de propriedade de um tio, irmão de sua madrasta.

Além disso, aos sábados, pela manhã, ela estudava inglês e, à tarde, participava de um grupo de jovens que se reuniam numa igreja católica, com o propósito de prestar assistência aos mais necessitados.

C. estuda nessa escola há quase três anos, mas, no começo, não queria ter ido para lá; só foi por ter cedido aos apelos da madrasta para ir estudar com sua irmã caçula. Sua relutância se devia ao fato de ela ter sempre estudado em escolas públicas e temer que, num colégio particular, os colegas fossem "chatos, cheios de frescura".

$\mathrm{Na}$ entrevista, C. contou que ficou órfã de mãe com poucos meses de vida, mas que, pouco depois, seu pai se casou com a mulher que hoje ela reconhece como sua mãe. Logo que se casou com seu pai, a madrasta deixou de trabalhar para "dedicar a vida dela" a C. e a seu irmão, que na época tinha 7 anos; quatro anos mais tarde, nasceu a irmã caçula de C.

Atualmente, C. vive com sua madrasta, de 45 anos, o irmão mais velho, de 22, a irmã caçula, de 12, e vários animais de estimação, afirmando que o relacionamento que mantém com eles sempre foi muito bom.

Com a madrasta e com o irmão mais velho, ela sente que pode contar sempre que necessário; com a irmã menor, desde a morte de seu pai, C. estabeleceu uma relação na qual se dispõe a "cuidar" dela, às vezes, até mais do que a própria mãe.

A jovem disse que tem muitos amigos, a maioria do sexo masculino, e que os conheceu nas várias escolas onde estudou, durante suas viagens para a casa de praia da família, entre os vizinhos e no grupo de jovens que freqüentava. Ela também contou que já teve vários namorados, mas um único relacionamento sério, aos 14 anos, e que durou cerca de seis meses.

No contato com a pesquisadora, fosse por seu discurso ou por sua postura, C. se destacou dos demais participantes por sua segurança ao se colocar e articular suas idéias, ao 
emitir opiniões que demonstravam reflexões e questionamentos próprios de uma jovem com mais idade do que ela.

C. foi a única participante indicada por uma outra menina, que não pôde participar do estudo por ter perdido o pai ainda bebê, mas que, além de sugerir o nome de C., também fez o primeiro contato com a amiga, incentivando-a a participar.

\section{Sua perda: a história de $\mathbf{C}$.}

Ao falar sobre a morte do pai, C. começou enfatizando que ele era policial e que levara um tiro no joelho, quando ela tinha 10 anos, momento que a "marcou muito", provavelmente porque, a partir daí, ela se deu conta da vulnerabilidade do pai e da possibilidade de ele vir a faltar a qualquer momento.

Por causa desse tiro, ele precisou fazer uma cirurgia, tendo logo em seguida adoecido e recebido o diagnóstico de pancreatite crônica, doença que depois de um ano e meio o matou, mesmo após contínuo tratamento.

C. explicou que essa doença acomete pessoas que fazem uso abusivo de álcool, mas que, como seu pai não bebia nem sequer "aquela cervejinha de final de semana" e seu avô morrera de câncer no pâncreas, ela concluiu que deve ter sido "alguma coisa genética".

Quatro anos atrás, quando da morte de seu pai, C. tinha 12 anos, e ele, 43. Ela ajudou a cuidar dele durante todo o tempo em que ele esteve doente e sempre teve clareza da gravidade de seu estado de saúde. Assim, quando sua mãe the contou que o pai havia morrido, a jovem não ficou surpresa e até já esperava por isso; segundo acredita, não houve nada a respeito da morte dele que não tenha sido devidamente esclarecido.

Disse também que, quando o pai morreu, ela foi ao velório, ao enterro e a todas as missas celebradas em sua memória não por ela mesma, mas para acompanhar a família, acrescentando que não costuma ir ao cemitério, como fazem sua mãe e sua irmã.

A respeito do relacionamento familiar antes do falecimento de seu pai, a jovem contou que seus pais se davam bem e que, embora trabalhasse muito, seu pai sempre que podia estava com a família.

No entanto, o pai era autoritário e exigente e não demonstrava carinho, de modo que C. mantinha com ele um relacionamento um pouco complicado, pois, apesar de "baixar a cabeça" para ele e procurar atendê-lo, ela o considerava suas proibições exageradas.

Por conta dessa postura do pai, ele e o irmão de C. brigavam muito, mas também discutiam porque o rapaz não admitia que o pai falasse mal da família da mãe biológica. 
Porém, quando o pai adoeceu, ele e o filho voltaram a se falar e o relacionamento entre eles melhorou um pouco.

Depois da morte de seu pai, sua madrasta deprimiu e ficou à parte de tudo, seu irmão refugiou-se na casa da então namorada e C. não ficava mais em casa, enquanto a caçula, por ser pequena, segundo a participante, não tinha a mínima idéia do que se passava.

Só depois de um ano e meio é que a família de C. voltou a se aproximar e a se reerguer, reestruturando-se, período que a jovem considerou necessário para que cada um deles pudesse começar a enfrentar a dor pela morte de seu pai.

\section{Vivências e manifestações relativas à sua perda e ao seu processo de luto}

\section{Reações imediatas}

Num primeiro momento, C. reagiu à morte de seu pai chorando e revoltada com o que acontecera com ele: "Eu chorei bastante, na hora... eu pensei em mil coisas, eu pensei em matar todo mundo, sabe? Eu não achava justo... Mas, foi só naquela hora, foi só naquele momento... e, depois, foi só aquele momento, mesmo, [em] que minha mãe me falou.”

\section{Vivências e manifestações subseqüentes}

Sobre o período de cerca de um ano e meio em que cada membro da família, inclusive ela, se isolou para enfrentar sua perda, C. reconheceu que isso na época a limitou:

"Eu vejo tipo um... um espaço, sabe? Que foi um tempo, cada um ficou na sua, eu fiquei muda, minha mãe ficou muda, minha irmã ficou muda, meu irmão também - cada um ficou na sua, pelo menos nas primeiras semanas, tipo uma coisa meio... não tinha o que falar, não tinha o que fazer."

"Eu... nesse um ano e meio, eu era muito mais fechada. Eu tinha os meus amigos e ponto. Eu não falava com quem não fosse meu amigo, entendeu? Eu era tipo um... eu, eu e eu, entendeu? $\mathrm{Na}$ época, eu era até roqueira, sabe? Aquelas coisas de vestir preto e... Mas... tipo... eu não era de conversar, sabe? Eu era meus amigos, meus amigos, saía com eles, fazias as coisas com eles. E eu me limitava."

Durante o período de seu isolamento, C. ficou livre para fazer o que bem entendesse e sentiu necessidade de usufruir dessa liberdade para se aproximar de tudo o que antes da morte 
do pai não the era permitido conhecer, mas com a idéia de que ela teria que "ser forte", diante dos limites apresentados pelos demais membros da família:

"Meu pai era uma pessoa muito... Ele era policial, então, ele não deixava eu fazer nada, sabe? Então, eu percebi que eu podia aprender com isso [referindo-se à morte do pai], sabe? Eu aprendi que, de repente, eu podia fazer tudo o que eu queria. Eu era muito, eu era presa, eu não podia nem pra ir pro shopping com a minha prima. E, logo depois, por exemplo, eu tive uma liberdade... Sabe? Tipo, além de o meu pai ter morrido, a minha mãe não... É, ela não 'tava me prendendo de nada... Então, eu aproveitei pra conhecer tudo aquilo que eu quisesse conhecer, entendeu? Eu tive, eu vi vários mundos, mas eu me sinto muito forte por causa disso, porque eu só olhei. Eu não fiz parte deles, entendeu? Eu conheci, eu vi, eu fui amiga de pessoas que faziam coisas que talvez eu tivesse vontade de fazer, na época. Por exemplo, eu andava com um pessoal que usava maconha. Tipo, eu olhava, só, eu olhava..., eu aprendi, vi, conhecei, mas não era o que eu queria pra mim. Então, eu vi, eu conheci e decidi que não queria, entendeu? Essas coisas que eu falo, tipo eu conheci, eu tive a liberdade, tipo, de uma janelinha, sabe?"

"Foi um ano e meio; eu me acho muito forte, sabe? Porque foi um ano e meio em que eu fazia o que eu queria, eu saía à hora que eu queria, voltava à hora que eu queria, eu 'tava onde eu queria, eu fazia o que eu queria. A minha mãe - sabe? -, foi um ano e meio que a minha mãe só dormia e chorava, sabe? Foi um ano e meio que ela ficou na cama, ela passava mal e vomitava. Foi tipo um ano e meio que eu podia fazer tudo, sabe? Tudo, tudo. E eu não fiz nada $[\mathrm{de}]$ que eu me arrependesse."

\section{Vivências e manifestações atuais}

Sobre as vivências e manifestações atuais relativas à sua perda e ao seu processo de luto, C. disse que às vezes sente falta do pai e, outras vezes, tem vontade de chorar, apesar de ter percebido que poderia aprender muito com essa situação, pois, com a morte do pai, teria maior liberdade para vivenciar novas experiências:

“Às vezes, me dá uma vontade de chorar, sabe? Algumas vezes, dá saudades, mas... Toda vez que eu me peguei pensando nisso, eu sempre tiro o lado positivo de tudo isso, sabe? Meu pai era uma pessoa... Ele era policial, então, ele não deixava eu fazer nada, sabe? Então, eu percebi que eu podia aprender com isso, sabe?" 
Além disso, C. também reconheceu que em muitos dos aniversários da morte de seu pai, para não ficar mal, ela procura sair com os amigos para se distrair e não pensar no pai e em sua morte:

"Aí eu tenho uns amigos que já até sabem essas datas - 17 de janeiro, 22 de janeiro - e depois eles passam em casa e falam 'vamo, vamo, vamo sair'. Aí, fazem eu tirar isso da cabaça, sabe? Aí, isso passa [...] faz o maior tempo, faz."

\section{Fatores de risco (vulnerabilidade) para luto complicado}

\section{Fatores predisponentes no enlutado e de sua relação com seu falecido pai}

Entre os fatores que predispõem C. ao luto complicado estão sua pouca idade por ocasião da morte de seu pai (12 anos, início da adolescência) e o fato de ela manter com o pai uma relação de dependência, quer pelo caráter desse vínculo, quer por ser pequena, na época (Bromberg, 2000). Além disso, o relacionamento entre eles parece ter sido marcado pela ambivalência, de modo que foi qualificado por ela como "um pouco complicado", pois, se, por um lado, C. reconhecia a dedicação do pai, por outro, incomodava-a seu autoritarismo. Essa ambivalência pode ter dificultado a ela a vivência de seu luto:

\footnotetext{
"Porque ele era policial e não deixava eu fazer nada. Se eu queria ir no shopping com a minha prima, não podia, porque ele não deixava. Ele queria tudo do jeito dele, sabe? Ele era muito mandão. E ele trabalhava demais; agora, toda oportunidade que ele tinha, ele 'tava junto, sabe? Ele não era de demonstrar carinho; tipo, ele gostava de assistir corrida, ele gostava que a gente sentasse e assistisse corrida com ele, sabe? Ah, sei lá, ele era muito bravo, ele era bem exigente, sabe? Ele queria que as coisas fossem perfeitas... Nota na escola, sabe? Ele, não, ele queria que fosse tudo certinho. Mas ele era tranqüilo, sabe? Eu abaixava muito a cabeça, pra ele. Com ele, eu não discutia. Eu perguntava uma vez, e só."
}

\section{Fatores relativos à perda em si}

C. contou que, desde que fora baleado, seu pai não voltou mais a ficar bem de saúde, até vir a falecer, dois anos depois, período durante o qual ele sofreu várias internações e cirurgias, o que representou um grande desgaste para a família e um fator adicional de estresse para esse grupo: 
"Bom, ele era policial. Aí, quando eu tinha uns 10 anos, ele levou um tiro no joelho; foi o primeiro momento, assim, que me marcou muito, sabe? Aí, chegou um monte de cara da policia lá, buscando coisa do meu pai, e eu não entendia nada. Aí, depois - depois de um tempo, acho que depois que ele fez a cirurgia -, melhorou, começou a dar uma doença, pancreatite crônica. É doença de alcoólico, mas meu pai não era alcoólico, ele não tinha costume nem de beber aquela cervejinha de domingo, nem isso. Mas meu avô também morreu de câncer no pâncreas, então, deve ser alguma coisa genética. Aí, ele começou a ficar doente, ficar doente, e descobriram; ele fez várias cirurgias, mas não deu... pancreatite crônica. Mais ou menos um ano e meio, ele ficou nessa."

"Sei lá, ela [madrasta] ia no hospital todo dia."

\section{Suportes sociais}

Nesse sentido, apesar de ter mencionado algumas pessoas que a ajudaram a enfrentar sua perda por cerca de um ano e meio após a morte do pai, C. não pôde contar com sua mãe e seus irmãos como suportes sociais, como já se disse. Nesse período, ela também se isolou da família e só se dispunha a falar e a se relacionar com seus amigos, mas não mencionou se pôde ou não contar com o apoio desses amigos para enfrentar a morte de seu pai:

"Eu acho que o que se perdeu seria tipo minha mãe [...] a gente meio que se afastou, em casa, mas isso já..."

\section{Outros}

\section{Expressão de vivências relativas à perda e ao processo de luto}

C. reconheceu que não teve facilidade em expressar suas vivências relativas à perda de seu pai e ao processo de luto decorrente dessa morte, já que se isolou e procurou manter a impressão de que tudo estava bem com ela:

"Não. Por aquilo que eu falei: eu me fechei. Eu não queria que ninguém soubesse, porque eu me via como... fechando, sabe? A minha mãe 'tava muito mal, meu irmão 'tava longe e a minha irmã era pequena, sabe? Então, eu tinha que... balançar tudo isso, eu tinha que manter tudo em equilíbrio, pra não... sei lá, alguém, de repente, não ficar perdido, sabe?" 


\section{Outras perdas}

C. perdeu sua mãe biológica quando era ainda uma recém-nascida. Logo em seguida, seu pai se casou e, desde o começo, a nova esposa assumiu C. e seu irmão como seus filhos:

"[...] ela cuidava de mim e do meu irmão, porque ela, na verdade, ela não é a minha mãe de verdade. A minha mãe biológica morreu, eu tinha meses, sabe? Tanto que meu nome mudou, mas é minha mãe, mesmo, sabe? Eu não vejo como se não fosse. Mas ela parou de trabalhar exatamente por causa disso: eu ia fazer um ano - eu era um neném. E tinha meu irmão, com 7 anos; então, ela parou de trabalhar e dedicou a vida dela pra mim, pro meu irmão."

\section{Fatores de proteção (e apoio) para luto complicado}

\section{Fatores relativos à perda em si}

Se, por um lado, todo o processo de adoecimento que levou o pai de C. à morte foi muito desgastante, comprometendo a vivência desse luto, por outro lado, como a deterioração de seu estado de saúde foi gradativa, também houve condições para que a jovem se preparasse para o pior e não fosse surpreendida pela morte dele: “A gente chorou bastante, mas eu já esperava, sabe? Eu sabia que isso ia acontecer e eu sabia que ele não ia pra praia, eu sabia que... aquela vez, no hospital, último dia que a gente - era a última vez, sabe? Coisa de sentir, sabe?"

\section{Suportes sociais}

C. mencionou algumas pessoas com que pôde contar e que a ajudaram a enfrentar sua perda e seu luto, como uma prima, da mesma idade que ela, uma amiga que também perdeu o pai na mesma época que C., e um tio, irmão da madrasta, que a considera como filha, além de outros amigos:

"Depois, eu lembro que eu saio, eu tinha saído pra... Bom, acho que ia fazer alguma coisa, chamar alguma amiga da minha mãe que morava perto de casa e aí, não sei o que foi que a minha prima falou pra mim, que meu deu um rolo, sabe?" 
"E eu tive uma amiga, também, que ela perdeu o pai, mais ou menos na mesma época. Ela sentia o mesmo que eu, então, a gente dividia as coisas, sabe? A gente conversava... É. Ela me ajudou bastante. A gente se apoiava uma na outra, quando a coisa 'tava difícil. De tudo, ela era muito igual a mim, sabe? E a mãe dela ainda ficou pior que a minha. A mãe dela tentava se matar, tipo psicologicamente, sabe? Ela deitava numa cama e desligava, sabe?"

"Eu acho que meu tio é meu pai, hoje, sabe? Porque ele fez muito... Por parte da minha mãe... Ele faz muito pela gente, sabe? Muito, muito, muito. Ele ajuda com dinheiro, sabe? Ajuda com... tipo, o material escolar deste ano, ele que comprou... Ele ajuda com essas coisas, sabe? Tipo ele supre... ele preenche a falta do meu pai, entendeu? Porque ele é solteiro, ele não quer casar, não quer ter filhos; então, os filhos dele é eu e meus irmãos."

"Aí, eu tenho uns amigos que já até sabem essas datas - 17 de janeiro, 22 de janeiro -, e eles passam em casa e falam 'vamo, vamo, vamo sair'. Aí, fazem eu tirar isso da cabaça, sabe?"

\section{Outros}

\section{Condições socioeconômicas}

Como no caso dos demais órfãos que participaram deste estudo, a família de C. passou a receber uma pensão do governo, após a morte de seu provedor. Mas, como a morte do pai de C. não se deu em serviço e, pelo relato da adolescente, ele provavelmente fazia "bicos", o padrão da família só foi parcialmente preservado:

\footnotetext{
"Em casa? De repente... eu sei que, quando eu tinha meu pai, tipo meu pai trabalhava, meu pai colocava dinheiro em casa, meu pai pagava as contas... e, de repente, eu percebi que... a coisa tem que girar, que a minha mãe, sozinha, não ia fazer isso."
}

No entanto, ainda assim, a família pôde contar com uma significativa ajuda do governo e com o apoio financeiro do já mencionado tio, irmão da mãe, solteiro, que não quer ter seus próprios filhos e que considera $\mathrm{C}$. e seus irmãos como sua responsabilidade.

Assim, do ponto de vista material, as conseqüências da morte do pai de C. foram razoavelmente contornadas e não produziram estresse adicional para a família. Além disso, as meninas puderam estudar numa escola particular, pois, por serem órfãs de um policial, receberam $100 \%$ de bolsa. 
"[o tio] ele ajuda com dinheiro, sabe? Ajuda com... tipo, o material escolar deste ano, ele que comprou... Ele ajuda com essas coisas, sabe? Tipo, ele supre... ele preenche a falta do meu pai, entendeu? Porque ele é solteiro, ele não quer casar, não quer ter filhos; então, os filhos dele é eu e meus irmãos."

"Porque ela [a irmã] achava que, lá, ela ia se sentir melhor (na escola em que elas estudam atualmente), mais protegida, porque é policial, 'tá num lugar, ali, tranqüilo, né? E, aí, como lá é particular, minha mãe pagava, só que, com a morte do meu pai, minha mãe pagava $50 \%$. Se eu entrasse na escola, seria bolsa de $100 \%$ pras duas."

\section{Crença em vida após a morte}

Apesar de não ter conseguido emitir sua opinião sobre a existência ou não de vida após a morte, C. mostrou-se incoerente quando disse que acreditava que, mesmo morto, seu pai continua a zelar por ela, crença que parece ter tido o mérito de fazê-la se sentir mais protegida:

"Entendeu? Eu acho que ele foi, em corpo. Eu sei que ele 'tá comigo, pelo menos pra mim, ele 'tá comigo a toda hora, sabe? Eu sei que ele 'tá vendo e que ele 'tá fazendo com que as coisas se dêem meio certo pra mim, entendeu? Tanto que eu acho que eu fui tão forte nesse um ano e meio, porque foi ele que queria que tudo fosse tão certo, que eu acho que eu tive a influência dele que me fez acertar nas minhas escolhas, entendeu?"

\section{Flexibilidade da estrutura familiar}

A família de C. levou algum tempo para se reestruturar, mas conseguiu efetivamente adaptar-se à ausência de seu provedor, ao atingir um padrão de união que lhe possibilitou redefinir papéis e redistribuir atribuições, demonstrando flexibilidade suficiente para sobreviver a sua perda e manter sua funcionalidade como instituição.

"Porque, de repente, a minha mãe, sendo mãe e pai, tendo que pôr comida, tendo que cuidar de filha, arrumar nossa casa, arrumar a casa, a gente se juntou, sabe? A gente se uniu e dividiu as coisas. Meu irmão ajudava em casa, com comida, com pagar conta, sabe? Eu ajudava a arrumar casa, e cada um fazia as obrigações, mas todo mundo fazia a coisa girar, sabe?" 


\section{Grau de comunicação e de união entre os membros da família}

Passado o choque inicial, para se adaptar à sua nova situação, os membros da família estabeleceram entre si um canal aberto para se comunicarem eficientemente, o que lhes possibilitou adquirirem um padrão de união que lhes favoreceu ajustarem-se à ausência da figura paterna:

"Então, acho que a gente se uniu um pouco mais, talvez, entendeu?"

\section{Presença de figuras substitutivas}

Com o tempo, a madrasta de C. acabou por substituir seu marido junto aos enteados e à filha em muitas das funções anteriormente exercidas por ele:

\footnotetext{
"Porque de repente, a minha mãe, sendo mãe e pai, tendo que pôr comida, tendo que cuidar de filha, arrumar nossa casa, arrumar a casa - a gente se juntou, sabe?"
}

\section{Estratégias de enfrentamento}

Logo depois da morte de seu pai, C. ouviu de um prima de sua idade um conselho de que ela nunca se esqueceu e que muito a ajudou a enfrentar a morte de seu pai:

\footnotetext{
"Depois, eu lembro que eu saí, eu tinha saído pra... Bom, acho que ia fazer alguma coisa, chamar alguma amiga da minha mãe que morava perto de casa, e não sei o que foi que a minha prima falou pra mim, que meu deu um rolo, sabe?... Ela me abraçou e falou 'meu, duas coisas: primeiro, você vai ter que ser forte, porque a sua mãe, você sabe como ela vai ficar, e a sua irmã é pequena." E o meu irmão - a gente nunca foi tão próximo, porque meu irmão vivia brigando com meu pai. Então, teve um tempo que meu irmão saiu de casa e morava como meu avô. E ela falou que eu tinha que ser forte, que eu não podia fazer, tipo, eu não podia me entregar às coisas erradas, sabe? Aos mundos errados, foi aquilo que... Ela é um ano mais velha do que eu."
}

Além disso, nos momentos em que sentiu dificuldades para fazer esse enfrentamento, ela se esquivou, procurando se distrair, na companhia dos amigos, para não pensar nisso. Segundo ela, há tempos ela não tem feito uso dessa estratégia: 
"Às vezes, me dá uma vontade de chorar, sabe? Mas é só na hora; aí, passa. Aí, eu tenho uns amigos que já até sabem essas datas 17 de janeiro, 22 de janeiro -, e eles passam em casa e falam 'vamo, vamo, vamo sair'. Aí, fazem eu tirar isso da cabaça, sabe? Aí, isso passa... faz o maior tempo"

Outra estratégia de enfrentamento que C. tem usado é sempre procurar resgatar os aspectos positivos das situações que vivencia, até mesmo da morte de seu pai:

"Toda vez que eu me peguei pensando nisso, eu sempre tiro o lado positivo de tudo isso, sabe? Ah, é uma coisa que, eu vejo como se tivesse que ser assim, entendeu? Hoje, eu me sinto privilegiada: eu tenho três famílias - quem é que tem? Quem é que tem? Eu tenho três famílias. Eu só vejo tipo, coisas boas, sabe?"

\section{Repercussões da perda para o adolescente e seu desenvolvimento}

\section{Representações atuais sobre si próprio}

Coerentemente com a postura que adotou em todos os contatos que teve com a pesquisadora, na entrevista, C. revelou perceber-se de forma bastante positiva, demonstrando autoconfiança e independência, embora se possa questionar se às vezes ela não chega a assumir uma postura um tanto auto-suficiente. No entanto, segundo ela, a morte de seu pai e suas repercussões para ela e para sua família lhe proporcionaram uma experiência que favoreceu seu amadurecimento:

"É tipo... foi um ano e meio, eu me acho muito forte, sabe? Porque foi um ano e meio em que eu fazia o que eu queria, eu saia à hora que eu queria, voltava à hora que eu queria, eu 'tava onde eu queria, eu fazia o que eu queria. A minha mãe - sabe? -, foi um ano e meio que a minha mãe só dormia e chorava, sabe? Foi um ano e meio que, tipo, ela ficou na cama, ela passava mal e vomitava. Foi um ano e meio que eu podia fazer tudo, sabe? Tudo, tudo. E eu não fiz nada [de] que eu me arrependesse."

"Eu me acho muito forte. Ah... sei lá, eu... acho que eu consegui superar tudo. Eu acho que tudo na vida é assim. Eu pus pra mim que isso foi a pior coisa que poderia ter me acontecido."

"Sei lá, eu acho que aprendi a ser independente, como você falou no começo, sabe? Eu aprendi a fazer as coisas por mim, a pensar em mim. Eu percebi que não tem quem vai se preocupar comigo, 
que eu tenho pensar em mim, que, se eu for fazer alguma coisa, eu não tenho que pensar no que os outros vão pensar, no que os outros vão querer, no que os outros façam. Eu aprendi a fazer por mim, sabe? Falei 'meu, toda a atitude minha, eu penso em mim. Se eu fizer isso, vai ser bom pra mim? Eu penso: vai ser bom pra mim?"”

\section{Representações atuais sobre o outro}

A partir de sua vivência de luto pela morte de seu pai, C. passou a adotar determinados padrões em seus relacionamentos, como buscar relacionar-se com muitas pessoas e preferir ter amizade com rapazes:

"Eu me apego demais às pessoas, hoje em dia. Eu tenho uma necessidade de estar com muita gente, de ter muita gente perto de mim."

"Eu fui pegando, de cada um, o que faltava do meu pai, entendeu? Tanto que a grande maioria dos meus amigos é homem. Eu vivo rodeada de homens, mas é amigo, mesmo; as pessoas olham, assim, vêem uma menina com um monte de menino e já pensam besteira; mas não, são meus amigos. Eu separo uma coisa da outra."

\section{Representações atuais sobre a vida em geral e expectativas sobre o futuro}

As atuais concepções de C. sobre a vida, a morte e seu futuro, bem como os limites que estabelece para si mesma, foram notadamente marcados pela morte de seu pai:

"Eu aprendi que o limite da vida é a morte, que a pior coisa é a morte, que a morte é a morte, sabe? Você vai morrer, passou... entendeu? Tipo, então, eu [...] viver cada dia de cada vez, entendeu? Eu sei que a única coisa que pode acontecer comigo que vai ter alguma reação maior seria eu morrer."

"Então, morrer - o que seria morrer? Eu só vou saber quando eu morrer, né? Então, eu vivo um dia de cada vez. O que eu faço, as coisas que eu acho certas, o que eu acho certo, eu aprendi que qualquer coisinha - coisa besta -, hoje em dia, eu não choro, você entendeu? Que eu vejo um monte de amigos meus brigando por causa de... brigando com os pais, sabe? Vejo muita gente chorando por briguinha com namorado, eu falo 'meu, isso, pra mim, não existe'. Jamais você vai me ver chorando por causa de namorado, sabe? Por coisa besta, entendeu? Eu acho que eu descobri que tudo tem um limite e que, pra chegar nesse limite, não é por qualquer coisa; então, eu não me preocupo com qualquer coisa, entendeu?" 
"Eu tinha que tirar nota por mim, e não pra ele; porque, antes, eu tirava nota alta pra mostrar o boletim pra ele. E depois, não - eu tinha que tirar nota alta pra mim, entendeu? Porque é o meu futuro, sabe? Eu não vou ter mais meu pai pra pagar a minha faculdade. Então, se eu quero alguma coisa, eu vou ter que eu lutar."

\title{
Estruturação familiar atual
}

Embora tenha sido preciso um certo tempo, a estrutura da família de C. parece ter atingido um padrão de reorganização que permitiu a seus membros adaptarem-se à perda do provedor, de modo que cada um passou a assumir responsabilidades que antes eram do pai ou estas foram dividas ente eles:

\begin{abstract}
"Porque não tinha mais quem corresse atrás de mim, porque, enquanto tinha meu pai, minha mãe e meu pai conseguiam dar conta de tudo... Só minha mãe, não dava pra ela fazer tudo. É muita coisa, o dia-a-dia de uma família. Daí, eu percebei que eu tinha que fazer por mim mesma, um pouco, sabe?"

"Então, acho que a gente se uniu um pouco mais, talvez, entendeu? Porque, de repente, a minha mãe, sendo mãe e pai, tendo que pôr comida, tendo que cuidar de filha, arrumar nossa casa, arrumar a casa, a gente se juntou, sabe? A gente se uniu e, tipo, dividiu as coisas. Meu irmão ajudava em casa, com comida, com pagar conta, sabe? Eu ajudava a arrumar casa, e cada um fazia as obrigações, mas todo mundo fazia a coisa girar, sabe?"
\end{abstract}

Nesse contexto, além de assumir novos compromissos no âmbito familiar como um todo, C. se propôs arcar com algumas responsabilidades também em relação à irmã e, segundo ela, às vezes se preocupando com a caçula mais do que sua própria mãe:

"Bom, da minha irmã, eu cuido diariamente, sabe? Conversar,
explicar de coisas de mulher, quanto a ajudar ela na escola. Um
pouco mais. Talvez... neste um ano meio, que era muito eu e
minha irmã, eu sempre fui fechada. Eu nunca fui de falar de mim,
mas eu percebi que a minha irmã não podia ser assim, também,
entendeu? Eu queria que ela conversasse com alguém, aí, eu me
propus a isso, a estar do lado dela, a entender ela, a conversar
com ela."

\section{Avaliação da entrevista}

Ao ser perguntada sobre sua motivação para ter atendido ao convite da pesquisadora e sobre como foi para ela essa experiência, C. deu a entender que aceitou participar do estudo 
por curiosidade, mas que se sentiu bem ao falar sobre sua perda e seu luto com um profissional que ela não conhecia:

\begin{abstract}
"Eu trabalho com coisas novas e, de repente, eu tinha um espaço no meu tempo... Ah, eu me senti bem, porque eu não gosto de falar da minha vida com todo mundo. E, de repente, você sendo psicóloga e sendo alguém que eu não conhecia, [com] que eu não tinha um contato, foi tranqüilo. Agora, se fosse uma pessoa que eu sei... que eu já tinha visto, que de repente eu sei que tem um contato com a minha mãe... um contato com outras pessoas próximas a mim, talvez eu não me sentisse bem.”
\end{abstract}

\title{
V.1.5 Caso M.
}

\section{Características do adolescente e de sua perda}

\section{Apresentando $M$.}

$\mathrm{Na}$ ocasião de sua participação nesta pesquisa, a jovem M. tinha 17 anos, cursava o $3^{\circ}$ ano do ensino médio e estudava nessa mesma escola havia cerca de dez anos, desde a época da morte de seu pai.

Antes de o pai morrer, M. era filha única e morava com ele e sua mãe; o pai trabalhava como policial, e a mãe nunca chegou a trabalhar fora.

M. descreve seu relacionamento com seu pai como "maravilhoso", dizendo que, apesar de ele nunca ter sido muito presente, pois trabalhava muito, sempre que podia ele estava com ela e fazia tudo o que ela queria. Disse que eles costumavam brincar e viajar juntos e que ele a levava a shoppings e a parques, e que raramente eles brigavam. Acrescentou ainda que é muito parecida com o pai, física e psicologicamente.

M. contou que sua família é muito numerosa e, de acordo com o relato dela, muito unida. Além disso, a jovem diz que tem muitos amigos e namora há um ano e meio.

$\mathrm{Na}$ entrevista, ela esteve disponível, emocionando-se bastante em alguns momentos e chegando às vezes a chorar, apesar de ter dito, a princípio, que não participaria deste estudo porque achava que seria entrevistada pelos psicólogos da escola onde estuda.

Segundo M., ela se recusaria a falar com a equipe da escola porque, como eles até então não se dispuseram a falar com ela sobre a morte de seu pai, agora, que ela já estava saindo da escola, era ela quem não queria mais conversar com eles. 
No entanto, depois de ter sido esclarecida sobre a pesquisa e de que ela não tinha nenhuma ligação com o trabalho realizado com os órfãos pela escola, M. decidiu participar e inclusive agradeceu a pesquisadora por tê-la convidado.

\section{Sua perda: a história de $M$.}

O pai de M. morreu há dez anos, quando ela tinha 7, num acidente de automóvel, a caminho do trabalho. Ela soube de tudo no mesmo dia, através de sua avó, enfatizando que nunca lhe esconderam nada a esse respeito.

M. contou ainda que pôde decidir se participaria ou não dos rituais fúnebres e que foi ao velório, ao enterro e à missa de sétimo dia, mas que decidiu não assistir ao sepultamento, temendo ficar traumatizada, se o fizesse.

Seus pais eram casados e moravam com M. num imóvel de sua propriedade, e a jovem deu a entender que a família tinha uma condição financeira razoável até a época da morte de seu pai e que, depois, mesmo com a pensão que elas passaram a receber do Estado, essa condição se deteriorou.

M. descreve seu relacionamento com o pai como "maravilhoso", revelando que, apesar de trabalhar muito, sempre que podia, ele estava com ela e fazia todas as suas vontades, tendo sido muito difícil para ela, depois de sua morte, adaptar-se a uma nova realidade, na qual ela não mais podia ter tudo o queria, como quando seu pai era vivo.

\section{Vivências e manifestações relativas à sua perda e ao seu processo de luto}

\section{Reações imediatas}

Ao saber pela avó materna que seu pai tinha morrido num acidente automobilístico, a reação inicial de M. foi chorar e se recusar a acreditar no que a avó lhe contava:

"Chorar. E não acreditar... Bom, além de não acreditar [M. faz silêncio e chora]... Além de não acreditar, eu queria falar com meu pai [voz de choro]... Eu, o que eu sentia... eu não queria acreditar, eu fiquei o tempo inteiro do lado do caixão, o tempo inteiro ali..." 


\section{Vivências e manifestações subseqüentes}

M. relatou que, logo depois da morte de seu pai, ainda era difícil para ela e para a mãe acreditarem e aceitarem que ele havia morrido, de modo que as duas choravam muito e precisaram se mudar do apartamento em que moravam com ele, pois lá tudo as fazia lembrarem-se dele. Além disso, M. disse que, ao ver sua mãe chorando tanto, concluiu que deveria ser forte para ajudá-la, pois, a partir de então, eram só as duas:

"[...] e, depois do enterro, eu sempre achava que ele ia chegar. O horário que ele chegava do serviço, eu ficava esperando. Aí - foi por isso -, minha mãe ficava esperando também, então, por isso que mudamos de lá."

"Porque era ruim. Você olhava pra tudo, você lembrava da pessoa. Então, era ruim. Eu tive que ser muito forte pra ajudar a minha mãe, porque ela ficava chorando. Aí, eu chegava, ela fala que eu... que achava inacreditável. Eu chegava pra ela e falava 'não, mãe, não chora, pára de chorar, a gente vai ficar bem, não precisa chorar, ele não quer ver você chorando.' Então, eu fui acho que - mais forte do que ela, porque, assim, apesar de ser muito nova, eu sabia que era eu e a minha mãe, então, eu tinha que ajudar a minha mãe."

"Que até o que eu falei, eu tive que ser forte pra ser um suporte para minha mãe."

Outra situação difícil para ela até hoje o Dia dos Pais, principalmente por conta das festas alusivas a essa data organizadas pela escola:

"Não. Porque até quando eu era pequena era muito mais difícil, chegava o Dia dos Pais [ela suspira e chora]... Mas, então, chegava o Dia dos Pais, aí, sempre tem festa no colégio e o pai de todos os meus amigos vinham..."

\section{Vivências e manifestações atuais}

A esse respeito, M. citou várias situações em que a perda do pai lhe desperta os mais diversos sentimentos, que revelam suas tentativas de se conformar com sua morte, mas denunciam que ela tem recaídas, pois sente sua falta e conversar com ele, ficando incomodada por ser diferente dos adolescentes que têm pai: 


\begin{abstract}
"Ah, sim. Ter que aceitar não ter mais, conformar - vamos dizer assim, né? - que, apesar de tudo, eu não tinha mais; então, eu tinha que me conformar com isso."

"Ah, sempre tem recaídas. Aquela parte que você quer porque quer o seu pai ali, com você, naquela hora; então, sempre tem uma época - não tem data, essas coisas, assim - sabe? -, que você fica bem pra baixo, querendo essa pessoa."

"Não sei, mas sempre fez falta, só que atualmente 'tava fazendo muita, muita, muita falta [a voz dela fica chorosa]."

"É esse fato de você estar na escola, você se relacionar com as pessoas que têm o pai; quando tem alguma coisa, o pai da pessoa vem, e você não 'tá com seu o pai..."

"Acho que a falta de... falta de uma conversa com pai, seria aquela conversa de pai, mesmo. Sim, eu converso com a minha mãe, mas acho que uma conversa com pai também ajudaria."
\end{abstract}

\title{
Fatores de risco (vulnerabilidade) para luto complicado
}

\section{Fatores predisponentes no enlutado e de sua relação com o falecido pai}

Entre os fatores que a predispõem ao luto complicado, estão sua idade ao perder o pai (8 anos) e o fato de ser menina - e, assim, tender a ser mais suscetível a essa perda -, sobretudo considerando-se a relação que M. mantinha com seu pai.

$\mathrm{Na}$ época, M. tinha um vínculo de bastante dependência e proximidade com o pai, por conta da natureza desse vínculo, da idade dela e do fato de ela ser a única filha, mas também por seu pai ter sido uma figura participativa no âmbito familiar e que assumia a função paterna de modo atuante. Nesse sentido, observa-se que M. ainda tem uma imagem idealizada do pai e do relacionamento que tinha com ele, percepção que, para a época da perda, condizia com a fase de seu desenvolvimento emocional, mas, hoje, pode comprometer a condição da jovem de elaborar seu luto:

"Maravilhoso [seu relacionamento com o pai]... Bom, ele era muito, assim, vamos dizer, não muito presente, porque ele trabalhava muito, mas, sempre que ele podia, ele 'tava comigo, ele fazia tudo, tudo, tudo o que eu queria, tudo. Ele brincava comigo, brigava também, quando precisava, 'tava sempre ali, comigo, sempre junto... Eu lembro só de que a gente saía pra comer, se divertia em casa, mesmo, sabe essas coisas assim? Bom, a gente ia muito em shopping, viajava, ia pra parque, vivia na paria, também... e ele tinha muito ciúme de mim. Até ouço comentário que, se o meu pai tivesse vivo, eu ia ver como ia ser o meu namorado na mão dele." 


\title{
Fatores relativos à perda $\mathrm{em}$ si
}

A morte do pai de M. por acidente de automóvel foi abrupta, o que se constitui em fator de risco para luto complicado:

\begin{abstract}
"Bom, ele morreu num acidente de trânsito. Minha mãe recebeu uma ligação de madrugada, umas cinco e pouco da manhã, dizendo que o amigo dele teria sofrido um acidente. E foi a mulher dele que ligou. Só que eles sempre estavam juntos, e minha mãe falou assim 'ah, se ele sofreu um acidente, então meu marido também 'tava'. Aí, ela ligou pra polícia e acabou ficando... ela acabou ficando desesperada, mas ela não falou o que era, porque eles não sabiam o que era. Aí, eu fiquei na casa da vizinha. Depois, minha avó chegou. Ela veio e ficou lá na casa da minha mãe. Aí, escutei minha avó gritando, falando 'não, não, não' tal. Aí, ela me chamou - aí, eles me chamaram - e minha avó falou que meu pai tinha morrido, falou assim; me trouxeram um copo d'água e falaram que meu pai tinha sofrido um acidente e que ele não tinha sobrevivido. Ele tinha morrido."
\end{abstract}

\section{Suportes sociais}

$\mathrm{Na}$ época da morte de seu pai, a jovem não pôde exatamente contar com o apoio da mãe, que ficou abalada a ponto de M. sentir-se compelida a ser forte para ajudá-la:

"Eu tive que ser muito forte pra ajudar a minha mãe, porque ela ficava chorando. Aí, eu chegava, ela fala que eu... que achava inacreditável. Eu chegava pra ela e falava 'não, mãe, não chora, pára de chorar, a gente vai ficar bem, não precisa chorar, ele não quer ver você chorando'."

Depois, sua mãe parece ter conseguido reagir, mas apoiando-se no fato de ter uma filha para criar, o que deixa dúvidas quanto às suas condições de dar à filha o devido apoio:

"Bom, apesar de ela ter ficado muito pra baixo, ela teve também que se preocupar comigo, que, agora, ela tinha uma filha para criar..." 


\title{
Outros
}

\section{Condições socioeconômicas}

Outro fator de risco para luto complicado diz respeito às condições econômicas da família de M. depois da morte de seu pai, pois ela e a mãe passaram por dificuldades que acarretaram mudanças nos hábitos da jovem, na época, entre elas, a mudança da escola particular em que estudava para a que estuda até hoje, também particular, mas onde, como filha de policial, ganhou uma bolsa de estudos:

\begin{abstract}
"Bom, a situação financeira [mudou] muito. Assim, foi o que mais pegou, porque tudo o que eu queria eu tinha. Então, de repente, aquele baque, então, não tenho, então, sempre a minha mãe ficava assim, porque eu pedia muito as coisas. Aí, eu tive que entender que não dava. Aí, eu parei de pedir."

"Eu fiquei mais um mês ou dois, porque minha mãe queria esperar as minhas férias escolares, pra poder mudar de escola, porque ela também não tinha mais condições pra continuar pagando aquela escola."
\end{abstract}

\section{Outras perdas}

Além de ter que mudar de escola, devido às dificuldades financeiras que a família atravessava, M. também precisou, durante cerca de um ano, morar na casa da avó materna, enquanto sua mãe se organizava para vender o imóvel da família, onde ela e a mãe não conseguiam mais viver por conta das lembranças do falecido que o apartamento suscitava. Essas mudanças representaram adaptações adicionais a que M. e sua mãe tiveram que se submeter e que podem ter lhes dificultado a vivência e a elaboração do luto:

"Então, foi assim. Eu fiquei depois morando um ano na casa da minha avó, até minha mãe achar um lugar pra gente morar, depois de receber indenização, seguro, tudo. Aí, minha mãe comprou outro apartamento, e nós mudamos pra esse apartamento."

\section{Vitimização}

M. revelou que, depois da morte de seu pai, passou a receber maior atenção das pessoas da família, que evitavam falar sobre sua perda e a tratavam de modo diferente, com 
receio de magoá-la, situação que não favorecia a jovem a expressar-se mais livremente com relação a seu processo de luto e não a reconhecia como capaz dos enfrentamentos necessários:

\begin{abstract}
"Aí, o relacionamento com as pessoas mudou, sabe? Passei a ter mais atenção da minha família, porque, por eu ter perdido meu pai muito cedo, então, comecei a entrar naquela coisa de as pessoas me tratarem de um modo diferente, sabe? Pra não me magoar, não tocar muito, assim, no assunto do meu pai, porque elas tinham medo do modo como eu ficaria."
\end{abstract}

\title{
Fatores de proteção (e apoio) para luto complicado
}

\section{Suportes sociais}

M. e sua mãe puderam contar com a ajuda de inúmeros parentes, principalmente do lado materno, mas também do paterno, bem como com o apoio de um dos amigos de seu pai que parece ter sido muito significativo para a jovem:

"Bom, minha família gostava muito do meu pai - muito, muito -, porque ele era uma boa pessoa. Então, todo mundo sentiu falta, todo mundo... ninguém conseguia acreditar, ninguém, ninguém. Mas eles foram um apoio pra gente, que muita gente veio auxiliar a gente, da família, sabe? Construir uma base de novo pra minha família. Meus avós, tios..."

"Não, minha avó também, que eu tenho só a avó, por parte de pai."

"Ah, bom, a família inteira, que eu até... Eu tenho uns tios que ajudaram muito, porque a minha mãe não sabia o que fazer, então, eles foram atrás dos assuntos do enterro, inventário, então, eles ajudaram; no que eles pudessem, eles ajudavam.”

"Amigos. Como o amigo do meu pai que ficou do nosso lado, não o que sofreu o acidente. Aí, teve um amigo do meu pai que foi quem instruiu a gente para me colocar aqui. Aí, depois, ele sempre liga, quando tem festa, sempre 'tá junto, assim, sabe? Não perdeu o contato. Isso. Aí, até fala que, se precisarem de alguma coisa, pra falar pra ele. Porque eu também vi que - como eu posso dizer? - que meu pai tinha alguém [com] que ele podia contar a qualquer hora." 


\title{
Outros
}

\section{A experiência com os rituais de luto}

Quanto aos rituais fúnebres do pai, M. teve total liberdade para optar por comparecer ou não a essas cerimônias, de modo que ela só não foi ao sepultamento, pois temeu não suportar testemunhar essa cena. O fato de ela ter sido respeitada em suas limitações certamente concorreu para favorecer sua vivência do luto, pois ela não foi instada a dar conta de tarefas que estavam além de suas condições:

\begin{abstract}
"A única coisa no funeral [a] que eu não fui foi na hora de enterrar. Não, eu não tive coragem... Minha [decisão de ir ou não aos rituais fúnebres]. Eu subi - que foi no parque do J. que ele foi enterrado -, então, eu subi toda aquela rampa, quando chegou lá em cima, eu não fui. Aí, eu não fui e fiquei esperando. Olha, eu acho que foi muito bom eu ter participado de tudo, menos do sepultamento, eu acho que eu ia ficar muito traumatizada. Porque eu ia ver tudo desabar."
\end{abstract}

\section{Ausência de segredos}

Segundo M., nada lhe foi ocultado sobre a morte de seu pai, por determinação de sua mãe, fator que pode tê-la ajudado a enfrentar a morte do pai, por sinalizar que ela era percebida como capaz de lidar com a verdade e evitar lacunas que permanecessem como incômodos:

"Não, porque ninguém me escondeu nada, todo mundo me falou tudo. Em nenhum momento minha mãe falou que era para esconder isso de mim, mas que era pra falar a verdade pra mim. Aí, foi isso."

\section{Crença em vida após a morte}

M. disse que o fato de ela acreditar em vida após a morte - não em reencarnação, mas no fato de que, depois que morrem, as pessoas ficam em outra dimensão - ajudou-a a superar a morte do pai, a confortá-la e a fazê-la sentir-se protegida por ele:

"Bom, a primeira coisa que eu falei pra minha avó e pra minha mãe, depois de tudo, foi que, como agora ele era - ele adorava 
estudar, ele gostava muito, sabe? -, então, falei assim para minha avó 'bom, avó, como ele sabia muita matemática, acho que Deus 'tava com dificuldade de fazer alguma conta e chamou ele.' Então, pra mim, ele 'tá vivendo em algum lugar, fazendo o que ele mais queria fazer, realizando todos os sonhos dele."

"[...] meu pai vai estar sempre comigo, o meu pai vai estar sempre me ajudando; de onde ele estiver, ele vai estar comigo."

\title{
Expressão de vivências relativas à perda e ao processo de luto
}

M. teve liberdade para se expressar com relação a sua perda e, pelo relato que fez, seus familiares foram bastante compreensivos no sentido de respeitar seus limites nesse sentido, pois sua primeira reação foi isolar-se:

\begin{abstract}
"Sim, porque eu conversava muito com as pessoas; tudo bem que, no começo, eu fugia. Fugia! Quando eu escutava alguém falando 'como a M. 'tá, depois que o pai dela morreu?', se eu escutava, eu saía. Até minha mãe falava: 'ela foge, ela não quer falar'. Só que, aí, depois, eu fui conversando, pra saber as coisas, perguntar mesmo por quê - por que que isso aconteceu, não sei. Sim. Bom, dependendo da minha reação, as pessoas vinham, me abraçavam, ou, se eu ficava mais arisca, as pessoas deixavam - uma hora ela vai querer falar, uma hora ela conversa."
\end{abstract}

\section{Presença de figuras substitutivas}

Com o tempo, a mãe de M. parece ter conseguido substituir o marido em suas funções paternas, o que pode ter favorecido à jovem a vivência de seu luto: "Mas eu sempre pensei que a minha mãe é minha mãe e meu pai...”.

\section{Presença de modelos de identificação positiva (e de proteção)}

Já M. mostrou-se bastante identificada com seu pai, ao perceber-se como muito parecida com ele, física e psicologicamente, percepção que fica suspeita frente à imagem idealizada que a jovem demonstra ter do pai, mas que pode ter fazê-la sentir-se fortalecida, protegida:

"Como eu poderia dizer? Super-parecida; eu era super-parecida com ele - em tudo. Fisicamente, psicologicamente, tudo. Ele brincava comigo, brigava também, quando precisava, 'tava sempre ali, comigo, sempre junto... Meu pai vai estar sempre 
comigo, o meu pai vai estar sempre me ajudando; de onde ele estiver, ele vai estar comigo."

\section{Estratégias de enfrentamento}

Uma das estratégias de M. para enfrentar a morte de seu pai e o processo de luto decorrente dessa perda foi procurar "amadurecer", mudar para se adaptar à nova situação e viver a vida no presente:

\footnotetext{
"Bom, eu tive que amadurecer muito rápido e até, sabe? Essas pessoas, assim, gente, eu vejo essas pessoas, assim, da minha idade, mas muito criança, com mentalidade bem baixa, eu fico inconformada. Mas, também, eu tive que amadurecer muito, porque minha situação mudou toda, minha vida mudou. Então, eu não poderia ser mimada do jeito que eu era. Sabe? Do jeito que eu 'tava. Então, eu tive que fazer uma revolução na minha vida - eu tive que amadurecer, entender as coisas. É assim; assim não pode, não dá, não tenho; então, é assim."

"Tem que ser muito forte para agüentar. Pensar em viver a vida."
}

Além disso, M. mencionou que, desde a morte de seu pai, ela freqüentemente sonha com ele, principalmente quando se aproxima a data em que ele morreu. Sobre esses sonhos, ela disse que, apesar de eles apresentarem conteúdos diferentes, em todos seu pai está morto e de todos ela desperta sentindo-se bem, pois acredita que seu pai está sempre por perto, protegendo-a:

"Só o fato de ele sempre estar morto... Bem... [sobre como se sente quando desperta desses sonhos]. Que ele 'tá sempre me protegendo."

\section{Repercussões da perda para o adolescente e seu desenvolvimento}

\section{Representações atuais sobre si mesma}

M. mostrou ter uma percepção positiva de si mesma, ao acreditar que precisou ser muito forte para enfrentar a perda e o processo de luto pela morte de seu pai, o que, segundo ela, também exigiu que se aproximasse mais da mãe e muito amadurecimento da parte dela: 
"Então, eu fui - acho que - mais forte do que ela, porque, assim, apesar de ser muito nova, eu sabia que era eu e a minha mãe, então, eu tinha que ajudar a minha mãe. Mas, também, eu tive que amadurecer muito, porque minha situação mudou toda, minha vida mudou."

Além disso, M. mostrou que segue identificada com o pai e que essa identificação compõe o perfil que ela faz de si mesma: "Como eu poderia dizer? Superparecida - eu era superparecida com ele... em tudo... Fisicamente, psicologicamente, tudo..."

\section{Representações atuais sobre o outro}

Sobre como a morte de seu pai influenciou seus relacionamentos, M. reconheceu que passou a ter maior necessidade de estar junto das pessoas, esforçando-se para se relacionar melhor com elas:

"Eu acho que me aproximei mais das pessoas. É, porque vem a carência, então, você quer atenção, você quer carinho, então, você começa a procurar mais as pessoas, a se relacionar melhor com as pessoas. Vamos dizer assim, é brigar menos, escutar mais, saber aceitar quando [você] está errado, é saber expressar sua opinião, sabe escutar alguma coisa, ver que está errado, não ficar quieto, falar, expressar suas idéias, seus pensamentos."

\section{Representações atuais sobre a vida em geral e expectativas sobre o futuro}

Em relação à vida e ao futuro, M. mostrou-se mais preocupada, pois acredita que, com a morte de seu pai, ficou menos amparada e com mais responsabilidades frente ao que acontecerá com ela:

\footnotetext{
"Do meu futuro? Houve. Porque eu tive que não pensar muito no agora, tive que ver o que ia fazer da minha vida depois. Eu vou ter que seguir um caminho, então, estabelecer metas e ir cumprindo todas, alcançando essas metas, faculdade, trabalhar pra pagar a faculdade, essas coisas."
}

Além disso, M. também revelou que passou a dar mais importância à família: "Eu fiquei mais família. Então, até minha mãe admirou isso. Ela falou assim: 'eu pensei que a M. ia me dar muito trabalho'. Mas não, eu fiquei mais família. Vamos dizer assim, dar mais importância pra família." 


\title{
Estruturação familiar atual
}

A família de M. parece ter conseguido se reestruturar diante da morte do pai, já que, além de assumir suas funções, sua mãe também passou a se responsabilizar pelas funções da figura paterna ausente. No entanto, vale acrescentar que, como a família é composta só por ela e a mãe, as duas só puderam contar com os próprios recursos, além do fato de que, por elas terem ficado ainda mais ligadas, depois da morte de seu provedor, M. possa de alguma forma encontrar dificuldades adicionais para obter sua autonomia. Nesse sentido, a jovem afirmou:

\begin{abstract}
"Então, eu fui - acho que - mais forte do que ela, porque, assim, apesar de ser muito nova, eu sabia que era eu e a minha mãe, então, eu tinha que ajudar a minha mãe. [...] Mas, assim, eu sempre pensei que a minha mãe é minha mãe e meu pai - o meu pai vai estar sempre comigo, o meu pai vai estar sempre me ajudando; de onde ele estiver, ele vai estar comigo."
\end{abstract}

\section{Avaliação da entrevista}

Sobre sua participação nesta pesquisa, a avaliação da jovem foi bastante positiva, quase como se ela precisasse viver essa experiência, e chegou a me agradecer por tê-la convidado:

"É. Obrigada pelo convite [...] Conversar, uma experiência nova, eu nunca tinha conversado disso com ninguém, a não ser da minha família, então, apenas conversar mesmo, sabe? É, ajuda muito. Bem, porque foram coisas que eu coloquei pra fora, sabe? Sentimentos, aquelas coisas mais presas aqui dentro, sabe? Obrigada pelo convite. Foi importante, porque, como eu nunca tinha conversado com ninguém... Aqui, na escola, tem, só que não é bem assim - não posso chegar a qualquer momento, chegar lá, nos psicólogos, e conversar. Só que não é um ambiente apropriado, porque eu estou na escola pra estudar. Eles também têm o trabalho deles, que não é um consultório de psicologia. Então, são universos completamente diferentes."

\section{V.2 ANÁLISE DO YSR}

\section{V.2.1 YSR DE K.}

As respostas de K. ao inventário YSR forneceram suas percepções sobre suas competências e problemas. Nesse instrumento, ela relatou que gosta de nadar e de andar de patins, mas atualmente só anda, às vezes, de bicicleta. Ela não tem nenhum hobbie, freqüenta 
uma igreja evangélica, trabalha na enfermaria da escola, como atendente e, em casa, é responsável por arrumar sua cama e lavar a louça.

Suas respostas indicam que ela tem dois ou três amigos mais próximos, que vê menos de uma vez por semana, fora do horário da escola. Ela considerou que se relaciona com os irmãos como a maioria dos jovens de sua idade, mas, quanto a outros jovens, julgou que se relaciona com eles pior do que a maioria dos jovens de sua idade.

K. considerou sua conduta em relação à mãe igual à de outros adolescentes de sua idade, mas pior que a deles no que diz respeito a realizar tarefas sem ajuda.

$\mathrm{Na}$ escola, K. situou seu desempenho em português, estudos sociais e ciências dentro da média, e abaixo da média em matemática.

Nas escalas que avaliam Competência total e Social, K. obteve escores inferiores à média dos jovens de 11 a 18 anos, situando-se, respectivamente, nas faixas clínica e limítrofe. Entretanto, seu escore na escala de Atividades ficou dentro dos padrões da faixa normativa, bem como seu resultado em Qualidades positivas.

Nas escalas Problemas totais e Problemas internalizantes, os escores de K. ficaram na faixa clínica, principalmente no que diz respeito a estes. Por outro lado, seu escore de Problemas externalizantes atingiu a faixa limítrofe.

Os resultados de K. nas síndromes Isolamento/depressão, Problemas de pensamento, Comportamento de quebrar-regras e Comportamento agressivo ficaram dentro da faixa normativa; nas síndromes Ansiedade/depressão e Problemas de atenção, na faixa clínica e, nas síndromes Queixas somáticas e Problemas sociais, atingiram a faixa limítrofe.

Assim, esses resultados indicam que K. reporta mais problemas que a maioria dos jovens de 11 a 18 anos, especialmente quanto à ansiedade, depressão, queixas de ordem somática, problemas de relacionamento social e problemas de atenção.

Nas escalas orientadas pelo DSM-IV, em relação a Problemas Somáticos, Déficit de atenção/transtorno de hiperatividade e Transtorno de conduta, os escores obtidos por $\mathrm{K}$. mantiveram-se na faixa normativa, mas, quanto a Transtornos afetivos, Transtornos de ansiedade e Transtorno opositor desafiante, seus escores atingiram a faixa limítrofe, o que sugere a necessidade de se consultar o DSM-IV para averiguar a presença de desordens caracterizadas por problemas relacionados a essas escalas.

Por fim, nas escalas de Transtorno obsessivo-compulsivo e de Transtorno de estresse pós-traumático, seus resultados ficaram na faixa limítrofe, o que indica a necessidade de se consultar o DSM-IV para o eventual diagnóstico de desordens relativas a essas escalas. 
Além dos escores das escalas, é importante considerar os dos itens de problemas individuais (itens críticos), especialmente aqueles em que o adolescente obteve escore 1 ou 2, que podem representar desafios particulares à habilidade de administrar situações.

A esse respeito, também devem ser examinados os comentários do informante sobre esses problemas, para se obterem mais informação sobre os riscos associados a eles e os contextos em que eles ocorrem.

No caso de K., não houve nenhum problema individual que se apresentasse nessas condições, conforme se pode observar pelo levantamento abaixo:

$\begin{aligned} \text { escore } & \text { problema } \\ 0 / 18 & \text { auto-destruição } \\ 0 / 40 & \text { ouvir coisas } \\ 0 / 57 & \text { ataques } \\ 0 / 67 & \text { fuga }\end{aligned}$

$\begin{aligned} \text { escore } & \text { problema } \\ 0 / 70 & \text { ver coisas } \\ 0 / 72 & \text { atear fogo } \\ 0 / 91 & \text { ideação suicida } \\ 0 / 105 & \text { usar drogas }\end{aligned}$

No Anexo V, apresentam-se os resultados originais obtidos por K. no YSR, emitidos pelo programa ADM.

\section{V.2.2 YSR DE J.}

O inventário YRS respondido por J. forneceu suas percepções sobre suas competências e problemas. Nesse instrumento, ele relatou que pratica duas modalidades diferentes de esportes, futebol e vôlei, tem dois hobbies, usar o computador e escrever, pertence a uma turma de amigos, a um grupo de músicos e, em casa, é responsável por lavar a louça e fazer sua cama.

Além disso, J. tem quatro ou mais amigos bastante próximos, com os quais se encontra uma ou duas vezes por semana, fora do horário da escola. Ele avalia que se relaciona com sua irmã tão bem quanto a maioria dos jovens de sua idade, mas que se dá com outros adolescentes melhor do que a maioria.

No que diz respeito à sua conduta diante de sua mãe e a fazer as coisas sem a ajuda de ninguém, J. achou que era igual a outros adolescentes de sua idade.

$\mathrm{Na}$ escola, em português, ciências, física, inglês e informática, o desempenho de J. é superior à média exigida; em estudos sociais e matemática, seus resultados estão na média. 
Nas escalas que avaliam Competência total, em Atividades e Social, o escore obtido por J. ficou dentro da faixa normativa, quando se consideram os relatos de jovens de 11 a 18 anos, da mesma forma que seu escore na escala de Qualidades positivas.

$\mathrm{Na}$ escalas que avaliam problemas, os escores de J. em Total de problemas e Problemas internalizantes atingiram a faixa clínica, com resultados aquém do que se espera de jovens de sua idade. Já na escala de Problemas externalizantes, seu escore ficou na faixa normativa, assim como nas síndromes Queixas somáticas, Problemas sociais, Problemas de atenção, Comportamento de quebrar-regras e Comportamento agressivo.

Entretanto, na síndrome Ansiedade/depressão, seu escore atingiu a faixa clínica, ao passo que, nas síndromes Isolamento/depressão e Problemas de pensamento permaneceu na faixa limítrofe, entre a faixa normativa e a clínica.

Seus escores nas escalas que avaliam problemas e nas síndromes indicam que J. apresenta mais problemas que a maioria dos jovens de sua idade, em particular, ansiedade, depressão, isolamento e problemas de pensamento.

Nas escalas orientadas pelo DSM, os escores de J. em Problemas somáticos, Déficit de atenção/transtorno de hiperatividade, Transtorno opositor desafiante e Transtorno de conduta encontravam-se na faixa normativa, mas, na escala de Transtornos de ansiedade, seu escore atingiu a faixa clínica e, na de Transtornos afetivos, a faixa limítrofe. Estes resultados sugerem que se deve consultar o DSM-IV para se averiguar a presença de critérios para o diagnóstico de Transtornos de ansiedade ou que caracterizem problemas englobados pela escala de Transtornos afetivos.

Nas escalas Transtorno obsessivo-compulsivo e Transtorno de estresse póstraumático, os escores de J. também atingiram a faixa clínica, indicando a necessidade de se consultar o DSM-IV para se determinar a presença ou não de critérios para o diagnóstico dessas desordens.

Num dos itens sobre problemas individuais - o 70-ver coisas -, J. obteve escore 1, o que levou ao cotejo com o formulário que ele preencheu, para esclarecimento da situação, mas nada indicou qualquer alteração significativa na saúde mental de J. 
A seguir, apresentam-se os resultados de J. nos itens relativos a problemas individuais:

$\begin{aligned} \text { escore } & \text { problema } \\ 0 / 18 & \text { auto-destruição } \\ 0 / 40 & \text { ouvir coisas } \\ 0 / 57 & \text { ataques } \\ 0 / 67 & \text { fuga }\end{aligned}$

\author{
escore problema \\ $1 / 70$ ver coisas \\ 0/72 atear fogo \\ 0/91 ideação suicida \\ 0/105 usar drogas
}

No Anexo V, apresentam-se os resultados originais obtidos por J. no YSR, emitidos pelo programa ADM.

\section{V.2.3 YSR DE R.}

No inventário YSR, R. emitiu suas percepções sobre suas competências e problemas. Nesse instrumento, relatou que pratica duas modalidades diferentes de esportes - joga futebol e anda de bicicleta -, tem três hobbies - empina pipa, joga videogame e desenha -, pertence a uma turma de amigos e faz tarefas domésticas como lavar a louça e fazer a cama.

Além disso, R. tem quatro ou mais amigos bem próximos com os quais se encontra uma ou duas vezes por semana, fora do horário da escola. Segundo sua própria avaliação, ele se relaciona com seus irmãos e com outros jovens melhor do que a maioria dos adolescentes de sua idade, assim como seu comportamento diante de sua mãe e sua capacidade de fazer tarefas sem ajuda.

Quanto a seu desempenho escolar, ele o julgou como acima da média em português, estudos sociais e ciências, e na média em matemática, física e literatura.

$\mathrm{Na}$ escala que avalia Competência total, o escore de R. ficou na faixa normativa em relação aos relatos de jovens de 11 a 18 anos, assim como seus escores nas escalas de competência Atividades e Social e na de Qualidades positivas.

Também ficaram dentro da faixa normativa seus escores nas escalas que avaliam problemas - Total de problemas, Problemas internalizantes e Problemas externalizantes -, nas diferentes síndromes abordadas pelo YSR e nas escalas orientadas pelo DSM-IV, inclusive nas de Transtorno obsessivo-compulsivo e de Transtorno de estresse póstraumático. 
Em relação aos itens que representam problemas individuais, R. não revela nenhuma alteração que justifique maiores investigações, como se vê no levantamento a seguir:

$\begin{aligned} \text { escore } & \text { problema } \\ 0 / 18 & \text { auto-destruição } \\ 0 / 40 & \text { ouvir coisas } \\ 0 / 57 & \text { ataques } \\ 0 / 67 & \text { fuga }\end{aligned}$

$\begin{aligned} \text { escore } & \text { problema } \\ 0 / 70 & \text { ver coisas } \\ 0 / 72 & \text { atear fogo } \\ 0 / 91 & \text { ideação suicida } \\ 0 / 105 & \text { usar drogas }\end{aligned}$

No Anexo V, apresentam-se os resultados originais obtidos por R. no YSR, emitidos pelo programa ADM.

\section{V.2.4 YSR DE C.}

O inventário YSR respondido por C. apresentou suas percepções sobre suas competências e problemas. Nesse instrumento, ela relatou que pratica três modalidades diferentes de esporte, natação, basquete e futebol, tem dois hobbies, ficar na praia e tocar violão, pertence ao grupo de jovens de uma igreja, trabalha numa farmácia e ajuda nas tarefas domésticas.

Além disso, C. tem dois ou três amigos mais próximos com os quais se encontra três ou mais vezes por semana, fora do horário da escola, e ela considerou também que consegue se relacionar com seus irmãos e com outros jovens melhor do que a maioria dos adolescentes.

No tocante a seu comportamento em relação a sua mãe e a fazer tarefas sem ajuda, C. considerou sua conduta semelhante à de outros jovens de sua idade.

Quanto a seu desempenho escolar, ela o julgou como acima da média em português, ciências, biologia e química, dentro da média em matemática e em estudos sociais e revelou que sente dificuldades em física.

$\mathrm{Na}$ escala que avalia Competência total, o escore de C. ficou dentro da faixa normativa em relação aos relatos de jovens de 11 a 18 anos, assim como seus escores nas escalas de competência Atividades e Social e de Qualidades Positivas.

Fosse nas escalas que avaliam problemas - Total de problemas, Problemas internalizantes e Problemas externalizantes -, nas diferentes síndromes avaliadas pelo YSR, nas escalas orientadas pelo DSM-IV, inclusive nas escalas de Transtorno obsessivo- 
compulsivo e de Transtorno de estresse pós-traumático, C. obteve escores dentro da faixa normativa.

No caso de C., em relação a problemas individuais, não houve nenhuma indicação de alteração, conforme se observar no levantamento a seguir:

$\begin{aligned} \text { escore } & \text { problema } \\ 0 / 18 & \text { auto-destruição } \\ 0 / 40 & \text { ouvir coisas } \\ 0 / 57 & \text { ataques } \\ 0 / 67 & \text { fuga }\end{aligned}$
escore problema
0/70 ver coisas
$0 / 72$ atear fogo
0/91 ideação suicida
0/105 usar drogas

No Anexo V, apresentam-se os resultados originais obtidos por C. no YSR, emitidos pelo programa ADM.

\section{V.2.5 YSR DE M.}

Através do inventário YSR, M. revelou suas percepções sobre suas competências e problemas. Nesse instrumento, ela disse que gosta de praticar natação, futebol e pesca e, como passatempos preferidos, citou a leitura, o canto e o uso do computador. Ela contou também que pertence a uma turma de amigos e ajuda a mãe nas tarefas domésticas.

M. tem quatro ou mais amigos bastante próximos, que vê menos de uma vez por semana, fora do horário da escola, e considerou que consegue se relacionar com outros jovens melhor do que outros adolescentes de sua idade.

No tocante a se comportar adequadamente em relação à mãe e a fazer tarefas sem ajuda, M. julgou sua conduta melhor do que a de outros adolescentes de sua idade.

No que diz respeito a seu desempenho escolar, M. relatou que, em português e estudos sociais, obtém resultados acima da média exigida pela escola, ao passo que, em matemática, ciências, inglês, física e química, ela fica dentro da média.

Nas escalas que avaliam competências - Competência total, Atividades, Social e Qualidades positivas -, os escores de M. ficaram dentro da média.

Nas escalas que detectam problemas, em Total de problemas e Problemas externalizantes, assim como em todas as síndromes avaliadas por esse instrumento, $\mathrm{M}$. apresentou resultados que se inserem na faixa normativa. Só na escala Problemas 
internalizantes é que sua pontuação atingiu a faixa limítrofe, o que indica a presença de problemas que englobam principalmente conflitos internos do adolescente, que muitas vezes não são perceptíveis por outras pessoas.

Nas escalas orientadas pelo DSM-IV - Problemas somáticos, Déficit de atenção/transtorno de hiperatividade, Transtorno de conduta, Transtornos afetivos, Transtorno opositor desafiante, Transtorno obsessivo-compulsivo e Transtorno de estresse pós-traumático -, os escores de M. ficaram na faixa normativa.

Entretanto, na escala Transtornos de ansiedade, seus escores atingiram a faixa limítrofe, o que sugere a necessidade de se consultar o DSM-IV para se investigar a presença de desordens caracterizadas pelos problemas incluídos nessa escala.

Além dos escores das escalas, devem se considerar os escores dos itens de problemas individuais (itens críticos), especialmente aqueles em que o adolescente obteve escore 1 ou 2 , que podem representar desafios particulares à habilidade de administrar situações.

Nos itens 40-ver coisas e 70-ouvir coisas, M. obteve escore 1, conforme se pode observar pelo levantamento apresentado a seguir:

$\begin{aligned} \text { escore } & \text { problema } \\ 0 / 18 & \text { auto-destruição } \\ 1 / 40 & \text { ouvir coisas } \\ 0 / 57 & \text { ataques } \\ 0 / 67 & \text { fuga }\end{aligned}$

escore problema

$1 / 70 \quad$ ver coisas

0/72 atear fogo

0/91 ideação suicida

0/105 usar drogas

Assim, examinaram-se também seus comentários acerca desses problemas, para se obterem mais informações sobre os riscos associados a eles e sobre os contextos em que eles ocorrem, concluindo-se que não representam indícios de alterações de sua saúde mental.

No Anexo V, apresentam-se os resultados originais obtidos por M. no YSR, emitidos pelo programa ADM. 


\section{DISCUSSÃO}

\section{VI.1 DADOS DE IDENTIFICAÇÃO DOS ADOLESCENTES}

Dos cinco adolescentes que participaram deste estudo, três eram do sexo feminino (K., M. e C.) e dois do masculino (J. e R.), com idades próximas, que variavam entre 16 e 18 anos (as moças K., M. e C. tinham, respectivamente, 18, 17 e 16 anos, e os rapazes J. e R., 18 e 16), de modo que todos estavam entre o fim da adolescência média e o início da tardia.

Quanto ao gênero dos participantes, constataram-se diferenças na forma de exporem suas vivências e as manifestações destas. No geral, as jovens se mostraram emocionalmente mais mobilizadas nas entrevistas, fazendo mais menções a reações afetivas, com um colorido emocional mais intenso do que as dos relatos dos rapazes.

Essa diferença deve-se provavelmente a questões culturais, pois em nossa sociedade as mulheres são mais estimuladas a expressar seus sentimentos, ao passo que dos homens se espera que eles não se alterem emocionalmente, o que pode ter contribuído para que os rapazes tenham escamoteado e coibido a manifestação de suas emoções, pelo exercício de um maior controle sobre elas, o que pode ter-lhes dificultado a vivência e a resolução do luto.

Esses resultados também foram observados por Franco; Mazorra; Tinoco (2002), em sua pesquisa sobre os fatores de risco para luto complicado numa população brasileira, apesar de a autora ter entrevistado pessoas mais velhas do que os participantes desta investigação. De todo modo, pode-se entender que, desde cedo, homens e mulheres já adotem posturas e condutas condizentes ao que se espera deles em termos de gênero.

Contudo, Worden (1996), ao estudar o luto de crianças e de adolescentes que perderam um dos pais, não identificou o gênero do enlutado como um determinante significativo de risco, defendendo que muito mais importantes eram dados como o funcionamento do genitor sobrevivente e sua adequação no cuidado dos filhos após a morte do cônjuge (Worden, 1996).

Por outro lado, na literatura há indícios de que as filhas, em função da morte de seus pais na infầncia, podem tender a ser, quando adultas, cuidadoras compulsivas ou se relacionarem com homens de maneira diferente do que quem não passou pelo luto (Pereira, 2004).

Quando participaram deste estudo, os jovens cursavam o ensino médio ( $2^{\circ}$ ou $3^{\circ}$ ano) numa escola particular que tem como um de seus objetivos atender a órfãos de policiais e todos tinham desempenho dentro da média do que se exigia nessa escola; apenas as jovens $\mathrm{K}$. e C. trabalhavam, em regime de meio período. 
Assim, a princípio, todos atendiam às demandas sociais próprias de sua idade, apesar de se ter verificado, através do YSR, que alguns apresentavam mais problemas em relação a determinados aspectos de sua saúde mental que a maioria dos jovens dessa faixa etária, o que será analisado adiante.

Todos os jovens viviam com a mãe, com quem o pai constituíra união estável e formal e morava até falecer, organização familiar que atualmente não caracteriza a maioria das famílias brasileiras e que talvez, nas famílias estudadas, se relacionasse ao fato de os pais serem policiais, indicando uma estruturação familiar mais rígida, mais conforme às convenções, mais tradicional.

De todas as famílias, só a de K. tinha uma estruturação menos convencional, pois, mesmo antes da morte de seu pai, a jovem já morava havia algum tempo com os avós maternos, que a criavam junto com sua família de origem, já que todos moravam muito próximos, condição que se manteve após a morte de seu pai e que era diferente da situação de seus irmãos, que sempre moraram com os pais.

A mãe de K., primogênita de uma prole de quatro filhos - composta por ela, dois adolescentes de 14 e 11 anos e uma outra menina, de 8, sua irmã só por parte de mãe, filha de pai desconhecido -, era a mais jovem (33 anos) das mães dos participantes, que em geral contavam com 40 e poucos anos, o que pode ter concorrido para dificultar a essa mãe enfrentar seu processo de luto e dar aos filhos o devido suporte e o necessário cuidado em razão da morte do pai (Worden, 1996).

A família de K. também se diferenciou das demais por sua mãe ter sido a única a se casar novamente, mas com um homem que, dois anos depois de se casar com ela, foi trabalhar no Japão, onde já está há quatro anos, de modo que esse casamento acabou não fazendo muita diferença prática na vida da jovem e de sua família.

M., por sua vez, era filha única e morava só com a mãe, que, na época do levantamento de dados desta pesquisa, tinha 41 anos, estruturação que acabava aproximando muito mãe e filha, tendendo a fazer com que uma se sentisse responsável pela outra.

A história familiar mais peculiar de todos os participantes era a de C., cuja mãe biológica falecera quanto ela era recém-nascida, deixando órfãos ela e um menino seis anos mais velho. Meses depois, seu pai se casou novamente, com uma mulher que criou C. e seu irmão mais velho. Dessa união, nasceu uma menina, com 12 anos, na ocasião deste estudo; a madrasta de C., que ela sempre reconheceu como sua única mãe, estava com 45 anos.

Entre os rapazes, J. era o caçula dos filhos, tinha uma única irmã, oito anos mais velha, e sua mãe, que na época em que se fez esta pesquisa também estava com 45 anos. Desde a 
morte do pai de J., sua mãe deixara de trabalhar, por conta de uma depressão, e, com o tempo, acabou se aposentando.

Já R., que era filho do meio, tinha um irmão de 19 anos, uma irmã de 10 e, na época desta pesquisa, sua mãe tinha 44 anos. Ela nunca trabalhara fora, mas recentemente se empregou numa loja, como balconista.

Com relação às famílias, deve-se lembrar ainda que, quando os pais sobreviventes têm que cuidar de muitos filhos, ou se, por serem pequenos, os filhos precisam de muitos cuidados, ou no caso de esses genitores não poderem contar com suporte social, sobretudo da família extensa, o estresse é maior e a administração do luto pode ser mais difícil. No entanto, nesse contexto, para os jovens enlutados, a presença de mais irmãos pode significar ter alguém para compartilhar e em quem se apoiar, bem como um meio de amenizar a disfuncionalidade do pai sobrevivente (Worden, 1996).

Dessa forma, quando se considera a organização das famílias dos participantes, podese fazer algumas observações e conjecturas. Por exemplo, no caso da família de K., em que todos os filhos eram bem pequenos quando o pai morreu, o quanto terá sido difícil para sua mãe se reorganizar para dar conta de seu próprio luto, de um filho recém-nascido, de um de 4 anos e de K., $\operatorname{com} 8$.

J. não tinha uma família extensa que o apoiasse, mas contou com a irmã, que lhe deu um modelo mais assertivo de enfrentamento da perda do pai, diante da impossibilidade de a mãe fazê-lo, acometida por grave depressão. Assim, de um lado, a estrutura familiar não lhe proveu certos recursos que poderiam ajudá-lo a enfrentar sua perda, mas, de outro, outras condições dessa família lhe garantiram algum norte.

Por sua vez, por ser filha única, M. não pôde contar com o apoio de irmãos, mas teve o suporte da família extensa, que a ampararam e à sua mãe, nas diferentes situações que elas precisaram enfrentar por conta da morte de seu provedor. No entanto, essa jovem parece ter se sentido tão responsável pela mãe, ter se unido a ela de tal forma - talvez por ser fillha única e, com a morte do pai, uma só poder contar com a outra -, que pode ter colocado em risco sua possibilidade de adquirir autonomia.

Quando à família de C., passado o choque inicial, seus membros puderam se unir de modo a se reorganizarem de forma efetiva, provavelmente também em decorrência do fato de C. e seu irmão já serem mais velhos, com mais condições de contribuírem para a reestruturação familiar, devido a uma melhor compreensão a respeito do que se passava e a maior autonomia que já tinham adquirido. 
$\mathrm{Na}$ família de R., devido à sua maior dificuldade para dar informações que permitissem uma melhor compreensão de como ele e sua família enfrentaram a morte de seu pai, não se podem aventar muitas hipóteses sobre como isso funcionava antes dessa perda ou sobre como essa organização influenciou o processo de luto de R..

Esses dados estão sintetizados no quadro abaixo:

\begin{tabular}{|c|c|c|c|c|}
\hline identidade & sexo & idade & $\begin{array}{c}\text { estrutura familiar } \\
\text { depois da morte }\end{array}$ & ordem de nascimento \\
\hline J. & m & 18 & mãe e casal de filhos & caçula \\
\hline R. & m & 16 & mãe, filho, filho e filha & filho do meio \\
\hline K. & f & 18 & mãe, filha, filho, filho e filha & primogênita \\
\hline M. & f & 17 & mãe e filha & filha única \\
\hline C. & f & 16 & mãe, filho, filha e fila & filha do meio \\
\hline
\end{tabular}

\section{VI.2 CARACTERÍSTICAS DA PERDA}

As mortes dos pais dos adolescentes tiveram causas diversas. Os pais de J., R. e K. foram assassinados, e pode ser que este último se tenha suicidado; o de C. ficou gravemente enfermo, vindo a falecer um ano mais tarde, depois de vários tratamentos e cirurgias, e o de M. morreu num acidente de trânsito.

Sabe-se que é mais difícil enfrentar a morte repentina do que a anunciada, sobretudo quando ela é violenta e mais ainda por suicídio. Entre as mortes anunciadas, aquelas que se sucedem a um longo e desgastante período de tratamento, com inúmeras internações e cirurgias, podem ser particularmente desgastantes.

Assim, pode-se considerar que as mortes dos pais de R., J. e K. tenham sido particularmente estressantes, sobretudo esta, que foi oficialmente reconhecida como suicídio, embora não se possa ignorar que as perdas de M. e de C. também tenham ocorrido em situações que envolvem algum risco para a resolução do luto, por terem sido, respectivamente, abrupta e desgastante, após um período de dois anos de tratamento, com internações e cirurgias (Franco, 2000b).

Em termos da idade que tinham na ocasião dessas mortes, os jovens podem formar três grupos: no primeiro, está J., que contava entre 3 e 4 anos quando perdeu o pai, há quase 15; no segundo, K. e M., que tinham respectivamente 8 e 6, há 10 anos, e no último, R. e C., que, há quatro e cinco anos, tinham 11 e 12. 
Como vimos, a idade da criança ou do adolescente à época da perda tem um papel importante em sua adaptação à nova situação, posto que a compreensão sobre a morte é a primeira condição para a elaboração do luto (Bromberg, 2000; Domingos, 2000; Bowlby, 2004b; Kovács, 1992). Portanto, os jovens tinham diferentes condições de compreensão da morte de seus pais. J., que contava 3 ou 4 anos quando perdeu o pai, provavelmente já tinha adquirido uma representação mental coerente das figuras de apego importantes como os pais, bem como uma constância do objeto, condição necessária para o luto (Worden, 1996).

No entanto, segundo Liotta (1996), só mais tarde, entre 8 e 10 anos, é que a criança é capaz de formar um conceito mais maduro sobre a morte, que inclui sua permanência, irreversibilidade, universalidade e inevitabilidade, associada à compreensão de que a morte implica uma parada total do funcionamento físico, o que condiz com o relato de J., que disse que só por volta dessa idade é que de fato se deu conta da morte de seu pai.

As jovens K. e M., que perderam seus pais aos 8 e aos 6 anos de idade, tinham, do ponto de vista cognitivo, alguma condição de entender o aspecto da permanência da morte, mas ainda não tinham a capacidade egóica e as habilidades sociais para lidar com a intensidade do sentimento de perda, o que provavelmente as deixou mais vulneráveis a ele e em parte ajuda a explicar a dificuldade de K. em se apropriar de seus sentimentos diante da morte de seu pai.

Para R. e J., que entravam na adolescência, havia condições, do ponto de vista cognitivo, de terem uma compreensão da morte mais semelhante à de um adulto, numa época em que eles começavam a viver as transformações típicas da adolescência, que também demandavam deles grandes investimentos, condições que, somadas, a princípio, devem tê-los sobrecarregado bastante (Liotta, 1996).

Ainda com relação a R. e C., de acordo com Fleming e Balmer (apud por Balk, Corr, 2001), como adolescentes mais novos e mais conscientes do que os mais velhos de suas diferenças em relação aos amigos, esses jovens seriam menos propensos a conversar sobre o luto com seus pares, o que pode fomentar a negação como uma estratégia de enfrentamento, proposição que pode contribuir para se compreender como R. processou seu luto.

Quanto à forma como os adolescentes enlutados receberam a notícia da morte do pai, não há semelhanças. Cada um teve uma experiência diferente, dependendo do tipo de morte e da idade que tinha na época, mas principalmente da forma como a família, notadamente o genitor sobrevivente, reagiu ao fato e lidou com ele.

A família de K., que tinha 8 anos quando perdeu o pai, optou por só lhe dar a notícia dias mais tarde; quem o fez foi uma tia, irmã de sua mãe, que mentiu dizendo que ele sofrera 
um acidente de trânsito. Só recentemente K. soube que seu pai fora assassinado e, depois, tendo tido a oportunidade de ler sua certidão de óbito, descobriu que ele teria se suicidado. Como isso contradiz a última versão dada a ela pela família - e que é sustentada por sua mãe -, a jovem passou a ter dúvidas quanto ao que de fato aconteceu com seu pai.

No caso de J., cujo pai morreu assassinado quando ele era muito pequeno, de certo modo, ninguém nunca lhe contou o que houve. Ele sempre conviveu naturalmente com o fato de não ter pai e, por volta dos 7 anos, começou a perceber o que tinha acontecido, mas só aos 10 entendeu mais claramente que o pai havia morrido e o que isso significava.

No entanto, embora ele acredite que, quando se deu conta do que houve, nada lhe foi ocultado, devido às circunstâncias dessa morte - o pai foi assassinado por um marginal enquanto fazia policiamento - e a comentários a respeito do destino do assassino e de o crime ter sido encomendado por um mandante, J. se pergunta até hoje pela verdade, e um certo mistério envolve essa morte.

Os jovens R. e M., cujos pais morreram subitamente - respectivamente, por assassinato e em acidente de trânsito -, foram logo informados do que se passara, sem qualquer omissão sobre essas mortes, apesar de M. na época só ter 6 anos e de nunca se ter sabido quem fora o autor ou qual fora a motivação da morte do pai de R., o que cerca de mistério também essa perda.

A morte do pai de $\mathrm{C}$. foi a única que não foi súbita. A jovem já vinha acompanhando sua doença havia cerca de um ano e meio, período durante o qual ele foi submetido a muitos tratamentos e cirurgias. Dias antes do falecimento, C. percebera que o quadro de seu pai se agravara e que sua morte era iminente.

Quanto à forma como os adolescentes souberam da morte de seus pais, principalmente no que tange a ter havido mistérios em torno do óbito, fator que tende a comprometer a vivência do luto, ficam mais compreensíveis as dificuldades de K., J. e R. frente à perda que sofreram, já que nem tudo acerca da morte de seus pais foi devidamente esclarecido.

Nesses casos, justificando-se pela necessidade de protegerem as crianças, os adultos costumam omitem delas informações acerca da morte que as atinge, estratégia que lhes acaba dando um modelo que não estimula o enfrentamento de uma realidade inquestionável e imutável, incrementa sua reação inicial de negação do luto e a idéia de que não têm condições de lidar com o luto e superá-lo (Mazorra, 2005; Bowlby, 2004b; Domingos, 2000).

Nessa mesma linha de pensamento, muitas vezes as crianças e os adolescentes podem ser desencorajados ou proibidos de participar dos rituais fúnebres de seus pais, o que pode 
impedi-los de ter um maior contato com a realidade da perda, favorecendo-se os sentimentos de defesa (Franco; Mazorra; Tinoco, 2002).

Segundo Worden (1996), esses rituais podem dar a crianças e adolescentes um meio de conhecerem a morte e de homenagearem o falecido, além de apoio e conforto. No entanto, o ideal é que eles possam decidir se querem ou não comparecer a essas cerimônias e sejam preparados para delas participar, com informações claras sobre o que vão ver e viver.

Quanto aos rituais do funeral, só K. e J. não participaram de nenhum, pois a família daquela só lhe contou que seu pai tinha morrido dias depois, e a mãe deste não permitiu que ele estivesse presente por considerá-lo muito pequeno, motivação que também deve ter levado a família de K. a ocultar-lhe a verdade.

Mas eles têm opiniões diferentes a esse respeito. K. disse que gostaria de ter participado desses rituais e de ter tido a oportunidade de ver seu pai uma vez mais, enquanto J. achou bom não ter ido, pois, em sua concepção, essas cerimônias são muito desagradáveis.

R. e C., que já entravam na adolescência - com 11 e 12 anos, respectivamente -, participaram de todas as cerimônias fúnebres de seus pais, mas em condições diferentes. R. não soube explicar por que considerou importante ter ido a esses eventos, e C. disse que foi só para acompanhar a mãe e a irmã, pois, para ela, eles não tinham nenhuma importância.

Finalmente, M., que na época da morte de seu pai tinha só 6 anos, também não soube explicar por que considerou importante ter ido ao velório, ao enterro e à missa, mas foi categórica ao afirmar que não presenciou o sepultamento por temer ficar traumatizada, pois achou que sentiria tudo desabar em sua vida, se testemunhasse essa cena.

Pode-se concluir, então, que, quanto à participação nos funerais, com exceção de K., os jovens tiveram experiências condizentes com suas condições, o que, na medida do possível, concorreu para entrassem em contato com a realidade que se apresentava e enfrentassem a perda que sofreram.

Sobre o relacionamento que mantinham com o falecido, com exceção de C., todos os jovens que participaram deste estudo apresentaram dos pais uma imagem idealizada, da qual praticamente só se ressaltaram as qualidades, e o único aspecto menos positivo mencionado foi o fato de eles trabalharem muito e terem pouco tempo para ficar com a família.

Sabe-se que a idealização do falecido é uma condição que dificulta a vivência do luto, na medida em que impede os enlutados de se relacionarem com uma figura paterna mais real. Como as extraordinárias virtudes do pai não podem ser encontradas em nenhuma outra pessoa, o enlutado pode ficar eternamente ligado ao morto (Bromberg, 2000; Worden, 1996).

Mesmo J., que disse que, por ter perdido o pai muito pequeno, não se lembrava muito 
dele e de como era sua convivência, descreveu-o como um "herói" e um modelo a ser seguido - talvez influenciado pelo fato de seu pai ter sido assassinado por um marginal, ao fazer policiamento, no cumprimento do dever.

R. e M. se declararam muito apegados aos pais, e R., que aos 11 anos perdeu o seu assassinado, enfatizou que, sempre que podia, o pai estava com a família e fazia tudo junto com eles, mas estranhamente afirmou que, após a morte do pai, nada mudara em sua vida, praticamente como se negasse o que tinha dito antes, provavelmente com dificuldade para constatar as conseqüências de sua perda.

M., filha única, salientou que o pai lhe fazia todas as vontades, descrevendo sua relação com ele como "maravilhosa" e contando que sua vida mudou radicalmente depois que ele morreu, pois antes tinha tudo o que queria e depois teve que aprender a lidar com os limites que gerou a ausência do pai.

Quanto a K., apesar de ela ter descrito seu pai como carinhoso e às vezes severo a ponto de castigá-la só pelo fato de ela ser a mais velha, ela também revelou uma imagem idealizada da figura paterna quando disse que, "como pai é pai, sempre fará falta".

No caso de C., talvez por ter perdido o pai já um pouco mais velha, no início da adolescência, ou talvez porque ele fosse mesmo mais difícil, sempre em conflito com o irmão mais velho da jovem, ela conseguiu fazer algumas críticas a ele - como seu autoritarismo -, apesar de também reconhecer nele qualidades.

\section{VI.3 VIVÊNCIAS E MANIFESTAÇÕES RELATIVAS À PERDA E AO PROCESSO DE LUTO}

\section{Reações imediatas}

As reações descritas pelos jovens deste estudo correspondem às apontadas na literatura como típicas de crianças e de adolescentes, que a rigor não são muito diferentes das dos adultos: chorar, ficar triste de nervoso, recusar-se a acreditar, sentir raiva e revolta etc. (Domingos, 2000; Liotta, 1996; Worden, 1996).

Quase todos choraram, com exceção de J., que não se lembra de ter tido qualquer reação à morte do pai, por ser muito pequeno na época e não contar com recursos cognitivos e emocionais que lhe permitissem reagir de outro modo. Ele ratifica essas limitações quando conta que só começou a entender a morte de seu pai com cerca de 7 anos, só adquirindo conceitos mais definidos sobre o fato aos 9 ou 10 e então reagindo efetivamente a essa perda. 
A recusa a acreditar que o pai estivesse morto acompanhou K. e M., principalmente K., que só soube da morte dias depois, não participou de nenhum dos rituais fúnebres e teve dificuldades até para relatar, na entrevista, que sentimentos teve quando recebeu a notícia.

No caso dessas jovens, também se deve levar em conta que elas eram relativamente pequenas - K. tinha 8 e M., 6 anos - quando essas mortes ocorreram e estavam numa fase de seu desenvolvimento em que podiam ter uma noção cognitiva do conceito de morte, mas ainda não tinham os recursos afetivos para gerir essa informação (Worden, 1996).

R. e C., que já entravam na adolescência quando perderam o pai, contaram que, além de ter chorado, sentiram revolta, raiva do mundo (C.) e nervosismo (R.), reações que no entanto só tiveram no dia da morte, pois a raiva e a revolta de C. logo se dissiparam, substituídas por outras reações, enquanto R. disse já que no dia seguinte se conteve, parou de chorar e não fez mais nenhum comentário sobre o assunto, como se nada tivesse acontecido.

\section{Vivências e manifestações subseqüentes}

Depois do impacto inicial, K. e M. continuaram a chorar pela morte do pai, mas, apesar de ter um pouco mais de idade do que M., K. ainda ficou um tempo esperando a volta do pai, com mais dificuldade para acreditar em sua morte, sem conseguir se alimentar adequadamente e não querendo que na escola soubessem que ela tinha ficado órfã, pois acreditava ser a única criança nessa situação, o que a constrangia.

A reação de M. parece ter sido muito influenciada pela de sua mãe, pois a jovem ficou muito sensibilizada pelo fato de a mãe não conseguir parar de chorar, o que parece tê-la mobilizado a ponto de levá-la a acreditar que precisava ser forte para apoiar a mãe.

Além disso, tanto para K. como para M., as festinhas da escola em que os pais eram convidados tornaram-se verdadeiros suplícios, embora M. tenha procurado reagir ao ver a mãe muito mal, o que a preocupou muito e a fez concluir que ela precisaria ser "forte" para apoiála, porque agora estavam só as duas, e uma dependia da outra.

J., que só começou a entender a morte de seu pai depois de anos, inicialmente se revoltou, perguntando-se por que isso teria acontecido com seu pai, refletindo sobre a natureza e as conseqüências do trabalho policial, sentindo-se triste, desanimado e fantasiando como seria sua vida se o pai ainda vivesse, mas compreendendo que todo mundo um dia morre.

R., por sua vez, manteve sua postura defensiva inicial, assumindo que só ficou triste por um mês, "se segurando", ao que tudo indica, seguindo a orientação e o exemplo de sua mãe, que, logo depois da morte do marido, segundo o jovem, manteve uma postura "normal" 
e disse aos filhos “Ah! Passou já, passou, passou, né? Vai viver a vida”.

Já C., adolescente quase da mesma idade de R. na época da morte do pai, procurou se isolar e passou a conversar só com amigos de sua idade, adotando uma postura de rebeldia, saindo muito e entrando em contato com universos diferentes, para conhecer tudo o que antes, quando seu pai era vivo, não lhe era acessível, já que ele a prendia muito em casa. No entanto, ela reconheceu que se limitou muito, por só se relacionar com os amigos.

Ao mesmo tempo, ela tentou ser "forte", pois, em suas incursões por mundos até então desconhecidos, C. procurou se preservar do que lhe podia causar algum tipo de dano, com o firme propósito de apoiar a madrasta e os outros membros da família, que, na sua concepção, não conseguiriam enfrentar a perda de seu provedor sem sua ajuda.

Observa-se que as reações das crianças e dos adolescentes são muito influenciadas pelas reações do genitor sobrevivente e dos outros adultos, sendo a negação e o isolamento reações que acompanharam os participantes deste estudo, mesmo após o impacto inicial.

Além disso, como defendeu Baker (1997), há reações primárias à perda de uma pessoa amada, mas há reações secundárias ligadas ao luto do pai (ou da mãe), ao medo de perder a ligação com a figura parental sobrevivente e a outras perdas que resultam dessa morte.

\section{Vivências e manifestações atuais}

Todos os jovens fizeram alusões a vivências dolorosas que os acompanham até hoje, independentemente do tempo transcorrido, o que corrobora a premissa que novos desafios, provenientes das exigências normativas do desenvolvimento ou de outros eventos significativos, além de estimularem a renovação do luto, podem criar novos modos para sua expressão.

Mesmo J, que perdeu o pai assassinado há quase 15 anos, mencionou que às vezes ainda sente tristeza e desânimo, sem vontade para nada. Consciente de que não pode mudar essa sua realidade, nessas ocasiões procura se distrair para não pensar no pai e em sua morte.

Para K., cujo pai também foi assassinado, há dez anos, nunca foi tão difícil lidar com sua falta como agora, principalmente depois da morte do pai de seu namorado, seis meses antes da realização desta pesquisa, quando a jovem passou a repensar a morte de seu pai, questionando seu sentido e suas conseqüências, mas se sentindo mais capaz de compreendêla, apesar de ter muitas vezes sentir-se injustiçada e confusa a esse respeito.

K. também contou que teme a morte de pessoas que lhe são caras, já que adquiriu a noção de que qualquer um pode morrer a qualquer hora, e hoje ela procura amenizar sua 
angústia abraçando e beijando seus entes queridos com muita freqüência.

Além disso, ela acredita que, se o pai estivesse vivo, seus irmãos estariam mais amparados, pois, em sua concepção, sua mãe não consegue cuidar dos filhos como deveria. Muitas vezes, K. se sente responsável pelos irmãos, talvez também porque ela teve a oportunidade de morar com os avós maternos, que têm uma postura bem diferente da de sua mãe, que é excessivamente liberal.

M., que também perdeu seu pai há dez anos, reconheceu que às vezes essa morte lhe desperta os mais diversos sentimentos, que revelam suas tentativas de aceitar essa realidade, suas recaídas, a falta que sente dele e o fato de se sentir diminuída em relação aos adolescentes que têm pai. Conta ainda que sonha muito com o pai, especialmente quando se aproxima seu aniversário de morte, e nesses sonhos ele sempre a está protegendo, apesar de estar morto, o que a faz sentir-se muito bem quando desperta.

$\mathrm{R}$. disse que às vezes ainda fica triste e nervoso, mas que procura não pensar no pai e em sua morte, o que de certa forma contradiz seu depoimento de que nada mudou, quase como se nada tivesse acontecido, chegando a afirmar que só ficou triste por um mês.

C. contou que às vezes sente falta do pai e tem vontade de chorar, mas procura tirar o que de positivo a morte dele representou para ela, explicando que, como seu pai era muito rígido e não a deixava fazer nada, ela percebeu que podia aprender muito com a morte dele. Acrescentou ainda que tende a ficar mal em seu aniversário de morte e que, para amenizar sua dor, muitas vezes ela procura se distrair passeando com amigos, para não pensar no pai e em sua morte.

\section{VI.4 FATORES DE RISCO (VULNERABILIDADE) PARA LUTO COMPLICADO}

\section{Fatores predisponentes no enlutado e em sua relação com o falecido}

Todos os jovens deste estudo perderam o pai quando eram crianças (J., K. e M.) ou no início da adolescência (R. e C.), condições que representam fatores de risco para luto complicado, já que, por ocasião da morte de seus pais, estavam em fases do desenvolvimento de grande vulnerabilidade.

No caso de K., sua insegurança e a imagem ruim que ela às vezes revela ter de si indicam sua baixa auto-estima, o que também é um fator de risco para luto complicado.

Nos cinco casos, o jovem vivia com ambos os pais e tinha com o pai uma relação de estreita proximidade e dependência, descrevendo-o como figura paterna atuante, que 
participava ativamente de sua vida, cuidava e se responsabilizava pelos filhos e apoiava a mulher no cumprimento de suas obrigações maternas. Sabe-se que a dependência também é um aspecto que tende a comprometer o enfrentamento do luto (Franco; Mazorra; Tinoco, 2002).

Ainda quanto à relação com o pai na época de sua morte, há outros fatores que podem ter dificultado a esses jovens a vivência de seu luto: para J., ele ter menos de 5 anos; para R., ser menino e ter perdido o pai na pré-adolescência; para K. e M., serem filhas pequenas (Bromberg, 2000).

Com exceção de C., as descrições que os jovens fizeram de seu pai foram muito idealizadas, dando-o como figura heróica, capaz de ações extraordinárias, provavelmente pelo fato de os participantes serem muito novos por ocasião de sua morte, mas também pela forma como cada um deles pôde lidar com essa ausência. Vale lembrar mais uma vez que a idealização pode dificultar a vivência do luto.

C. foi a única que apresentou uma imagem mais real de seu pai, com qualidades e defeitos, talvez pelo fato de, na época de sua morte, ser a mais velha de todos os participantes, já com 12 anos. Mas a relação entre a jovem e seu pai continha certa ambivalência, pois, além de the reconhecer o valor, ela se queixou de que ele não a deixava fazer nada, o que a princípio pode ter dificultado a vivência desse luto, como já foi dito (Worden, 1996).

\section{Fatores relativos à perda em si}

Reconhecidamente, a natureza da morte pode ser fator de risco para luto complicado, quando se trata de mortes violentas e súbitas, como aconteceu com os pais de K., J. e R., que foram - sobretudo no caso do primeiro, em que há suspeita de suicídio -, mas também com o pai de M., morto repentinamente num acidente de trânsito.

No caso de C., que perdeu o pai devido a uma doença crônica que o assolou por cerca de um ano e meio, depois de ele ter sido baleado, pode-se pensar que as inúmeras internações e cirurgias por que passou seu pai representaram para a jovem e sua família um período de desgaste e um fator adicional de estresse.

Finalmente, deve-se considerar ainda que a existência de fatos obscuros quanto às circunstâncias que cercaram essas mortes representa um notório fator de risco, principalmente no caso do pai de K., mas também no dos pais de J. e de R., como já se disse antes. 


\section{Suportes sociais}

No que diz respeito aos suportes sociais com que puderam contar os enlutados entrevistados neste estudo, considerou-se não só a existência desse apoio, como sua natureza e qualidade, já que, dependendo de como ele acontece, pode dar algum alento, mas também desconforto, se restringir as manifestações relativas à perda e ao luto.

Um exemplo claro é o apoio recebido por K., que tinha 8 anos quando perdeu o pai, assassinado. Em nenhum momento ela mencionou qualquer tipo de apoio de sua mãe, embora tenha feito alusão a outras pessoas da família que cuidaram dela e procuraram consolá-la. $\mathrm{Na}$ verdade, ela várias vezes salientou a dificuldade da mãe para cuidar adequadamente dos filhos, justificando-a por ela ser muito nova e ter sofrido um grande choque com a morte do marido, o que ratifica as limitações dessa mãe quanto ao apoio que pôde oferecer a K. por conta da morte de seu pai. No entanto, o alegado apoio que a jovem teria recebido dos parentes da mãe parecia, em muitos momentos, que se destinava mais a conter suas expressões relativas à morte de seu pai do que a acolhê-la - na entrevista, ela se queixou de que as pessoas lhe pediam que parasse de chorar porque não compreendiam que sua necessidade nesse sentido.

Mas K. não foi a única que não pôde, na época da morte do pai, contar com o apoio do genitor sobrevivente. Também as mães de J. e de C. ficaram - ao menos por um tempo - tão consumidas por seu próprio luto, em franca depressão e num estado mental tão deplorável, que tiveram pouca ou nenhuma condição de perceber as necessidades dos filhos enlutados e de assisti-los adequadamente.

Por ocasião da morte do marido, a mãe de J. precisou inclusive afastar-se do trabalho, tendo sido aposentada por depressão depois de várias vezes licenciada. A mãe de C. ficou cerca de um ano e meio completamente alheia ao que se passava a sua volta, impossibilitada de dar aos filhos a devida atenção. C. inclusive relatou que, durante o período em que sua mãe permaneceu nesse estado, ela e seus irmãos também se isolaram, de modo que nem entre os irmãos foi possível encontrar apoio. Na época, ela só se relacionava com os amigos, mas não disse se pôde ou não contar com o apoio desses amigos para enfrentar o luto por seu pai.

Embora não tenha ficado tão impedida quanto as mães de J. e de C., a mãe de M. também ficou muito mal, a ponto de a menina ter concluído que precisava ser forte para cuidar dela. Depois ela parece ter melhorado, especialmente porque começou a se apegar à idéia de que precisava cuidar da filha, mas não ficou claro se ela realmente passou a lhe dar o devido apoio. 
A preocupação de M. em relação ao estado mental de sua mãe também foi sentida por C. e por J., mas, neste último caso, depois de anos da morte do pai, quando ele se deu conta do que acontecera e do quanto a mãe tinha ficado mal. Também C. e J. se propuseram ser fortes para dar apoio a suas mães, que, em sua percepção, precisavam da ajuda dos filhos.

Quanto à mãe de R., ele não especificou se recebeu dela algum tipo de apoio, mas disse que, logo depois da morte do pai, a mãe se mostrou "normal", como se nada tivesse acontecido, dizendo aos filhos que "Ah! Passou já, passou, passou, né? Vai viver a vida", o que sugere que ela não só negou a tragédia vivida pela família, como instou os filhos a fazerem o mesmo, dando-lhes um modelo nesse sentido.

Quanto a outros suportes sociais com que os jovens não puderam contar, ainda foram mencionadas as famílias dos pais de J., vivendo os parentes da mãe em outro estado e sendo os do pai afetivamente distantes de J., exceto por um tio, irmão do pai.

Outro dado é que nenhum dos jovens citou a escola onde estudava ou qualquer outra instituição como fonte de qualquer tipo de suporte para si ou para sua família, com exceção da escola onde estudam atualmente, na qual puderam contar com bolsas de estudo e apoio psicopedagógico, por serem órfãos de pais policiais. Até pelo contrário, K. e M. temeram viver na escola situações constrangedoras, especialmente quando se organizavam evento que contavam com a participação dos falecidos, o que as fazia sentirem-se diferentes, diminuídas em relação aos colegas que tinham pai.

\section{Outros}

Alguns fatores podem facilitar ou dificultar o processo de luto, dependendo das circunstâncias que os cercam e de como são vividos. Descrevem-se a seguir situações em que se identificaram fatores que podem ter prejudicado a vivência do luto de alguns dos jovens.

\section{A experiência com os rituais de luto}

De todos os participantes, K. foi a única que, apesar de não ter comparecido aos funerais de seu pai, gostaria de ter ido, opção que não lhe foi dada pela família, pois na época ela nem soube de sua morte e, quando soube, foi em circunstâncias que podem lhe ter dificultado a constatação e a resolução de sua perda, aspecto já discutido anteriormente. 


\section{Expressão de vivências relativas à perda e ao processo de luto}

Entre os jovens entrevistados, J. relatou que não se sentiu no direito de perguntar muito sobre o que havia acontecido, justificando-se com o fato de que, diante de situações como a morte de seu pai, ele prefere se calar, o que pode tê-lo impedido de obter a legitimação de sua dor e lhe dificultado a resolução de seu luto.

Do mesmo modo, C. também se descreveu como reservada, contando que na época da morte de seu pai ela acabou se isolando, mas que até hoje sente dificuldades e evita se manifestar quanto a essa sua perda.

Situação não muito diferente foi relatada por R., que não conseguiu se expressar em relação a mote de seu pai, mas em cujo relato ficou evidente que ele também não foi encorajado a isso, mas, pelo contrário, sua mãe lhe deu um modelo de como lidar com a morte do pai que o impelia a deixar essa perda no passado.

Finalmente, K. ressaltou muitas vezes sua necessidade de se manifestar pela morte de seu pai, mas, ao mencionar o apoio que recebeu de seus familiares, deixou claro que ele foi restritivo nesse sentido e que ela se ressentiu disso.

Conclui-se, então que, a possibilidade de se expressar livremente com relação à morte do pai pode ser muito importante para a ressignificação dessa perda, o que nem sempre é tão fácil e depende de características do próprio enlutado, mas também de um ambiente propício. Nesse sentido, deve-se lembrar que, socialmente, principalmente no caso de crianças e adolescentes, essa expressão não é encorajada (Franco; Mazorra; Tinoco, 2002; Domingos, 2000; Worden, 1996).

\section{Condições socioeconômicas}

Para M., a morte de seu pai acarretou mudanças nas condições socioeconômicas que a obrigaram a se transferir da escola em que estudava e a modificar radicalmente seus hábitos cotidianos, pois, quando seu pai era vivo, costumava fazer-lhe todas as vontades. Essas mudanças devem ter acarretado estressores adicionais, que se somaram à necessidade de $\mathrm{M}$. de enfrentar sua perda, sobrecarregando-a um pouco mais. 


\section{Presença de modelos de identificação negativa (de vulnerabilidade)}

R. parece ter seguido a atitude da mãe como modelo de enfrentamento de sua perda. Ela enfatizou a necessidade de se assumir uma postura "normal" e continuar a viver a vida, mas sem criar para si ou estimular os filhos a criarem um espaço para expressar sentimentos relativos à perda sofrida, o que pode ter dificultado a R. a vivência de seu luto.

Como já se disse, as crianças e os adolescentes precisam viver a dor para viver seu luto (Domingos, 2000) e, nesse sentido, as reações dos pais sobreviventes têm um grande impacto sobre eles (Worden, 1996), pois a possibilidade de contarem com um adulto quem possam conversar sobre isso pode facilitar a vivência desse luto (Liotta, 1996).

\section{Outras perdas}

C. e M. tiveram outras perdas que podem ter-lhes dificultado a vivência do luto, embora fossem perdas de naturezas diferentes e se tenham dado em momentos distintos da vida de cada uma. C. perdeu a mãe biológica quando era recém-nascida, mas deve-se considerar que seu pai logo em seguida se casou e desde o início a madrasta a assumiu como filha. M. e sua mãe tiveram que se mudar do apartamento em que moravam com o pai quando ele morreu, por não suportarem as lembranças que lhes trazia. Por causa disso, foram viver com a avó de M. por cerca de um ano, até comprarem outro imóvel para morar sozinhas, o que provavelmente exigiu algumas adaptações por parte da jovem e foi um desgaste adicional.

\section{Vitimização}

K. e M. mencionaram que, depois da morte do pai, passaram a ser tratadas de modo diferente por seus familiares. Por serem órfãs, os parentes temiam magoá-las e as poupavam excessivamente, o que pode ter contribuído para que elas se percebessem aquém da possibilidade de enfrentar a vida e dificultado a resolução do luto que viviam. 


\section{VI.5 FATORES DE PROTEÇÃO (E APOIO) PARA LUTO COMPLICADO}

\section{Fatores relativos à perda em si}

Diferentemente do que aconteceu com os demais participantes, C. não ficou chocada com a perda de seu pai, pois ele estava doente havia cerca de um ano e meio, e ela o acompanhara durante todo esse tempo, de modo que já esperava sua morte; dias antes, ela notara que seu estado de saúde tinha piorado. Assim, apesar de todo o desgaste do longo tempo de tratamento, durante o qual seu pai fora internado várias vezes e submetido a diversas cirurgias, ela contou com o fato de essa morte ter sido anunciada e foi aos poucos se preparando para enfrentar essa perda algo mais protegida (Franco; Mazorra; Tinoco, 2002).

\section{Suportes sociais}

R. contou que se sentiu apoiado e compreendido por familiares e amigos, que procuraram ficar junto dele, embora sem se falarem e sem que o jovem conseguisse explicar como foi esse apoio, como ele se sentiu compreendido ou o porquê de sua importância.

Para J., o apoio veio de um tio, irmão de seu pai, que nunca tinha sido próximo dele, mas que apoiou sua família na época da morte do pai e, mais tarde, quando ele se deu realmente conta de sua perda, foi alguém em quem o jovem encontrou suporte para sua dor.

Quanto a K., apesar de sua família nem sempre ter assumido uma postura das mais adequadas para apoiá-la e ajudá-la a enfrentar sua perda, se dispôs a cuidá-la e a estar com ela, oferecendo-lhe um mínimo de apoio, especialmente diante das limitações de sua mãe para assumir suas funções e as do falecido pai.

C., por sua vez, apesar de um período inicial de isolamento, contou com o apoio de amigos e familiares, quando da morte de seu pai, mais especialmente depois de certo tempo. $\mathrm{Na}$ época da perda, ela teve o apoio de uma prima da mesma idade, que a estimulou a ser forte, conselho que parece ter sido depois muito importante para a jovem. C. também recebeu suporte de uma amiga da sua idade que também perdera o pai. Na família, o apoio veio do irmão de sua madrasta, que até hoje procura assisti-la e a seus irmãos em suas necessidades.

No caso de M., ela também contou com o apoio de muitos familiares, principalmente de parentes de sua mãe, mas também de seu pai. Há ainda um amigo do pai com quem ela e a mãe podem contar, o que, para M., é um alento a mais, pois significa que seu pai tinha alguém por si em qualquer circunstância. 
Desse modo, reitera-se que, de fato, o apoio social e o modo como ele se dá são fundamentais para o enfrentamento do luto.

\section{Outros}

\section{A experiência com os rituais de luto}

Apesar de não ter participado do velório ou do enterro do pai - pois na época ele era muito pequeno, e sua mãe não permitiu que ele fosse a essas cerimônias -, J. não se incomodou com isso; pelo contrário, achou até bom, por entender que essas experiências são desagradáveis e sem significado algum para ele.

Desse modo, ainda que acidentalmente, J. parece ter sido respeitado em suas limitações, o que pode ter-lhe favorecido o enfrentamento de seu luto de acordo com suas possibilidades, preservado de demandas além do que ele poderia atender.

R. e M. se declararam satisfeitos por ter participado dos rituais fúnebres de seus pais, apesar de não terem conseguido explicar a importância dessa oportunidade para eles. É provável que a oportunidade de comparecer a esses rituais os tenha ajudado a aceitar a perda.

Já C. disse que só foi a essas cerimônias para acompanhar a irmã e a madrasta, porque, para ela, não têm nenhum significado. Isso indica que sua necessidade era estar perto e apoiar as pessoas de que gosta, recurso que ela parece ter usado para enfrentar sua perda.

\section{Ausência de segredos}

Segundo M., por determinação de sua mãe, nada lhe foi ocultado sobre a morte de seu pai, o que pode tê-la ajudado a enfrentar essa perda, por sinalizar que ela era percebida como capaz de lidar com a verdade e evitar lacunas que permanecessem como incômodos, favorecendo a vivencia de seu luto (Franco; Mazorra; Tinoco, 2002).

\section{Condições socioeconômicas}

Nenhum dos participantes, à exceção de M., disse que a morte do pai representou uma queda significativa do poder aquisitivo da família, de modo a implicar a necessidade de mudanças radicais de hábitos.

As famílias de J. e R., cujos pais morreram durante o serviço policial, passaram a 
receber do Estado uma pensão que correspondia ao valor integral de seus vencimentos, o que parece ter preservado sua condição socioeconômica e evitado problemas que poderiam ter adicionado mais estresse ao processo de luto desses jovens.

No caso de J., mesmo com a aposentadoria de sua mãe - devido à depressão que a acometeu depois da morte do marido -, a redução dos recursos financeiros da família deve ter sido mínima e, mais tarde, pode ter sido compensada, em parte, pelo fato de a irmã de J. ter começado a trabalhar.

As famílias de K. e C. não continuaram a contar com os mesmos recursos, pois, apesar de também receberem pensão do Estado, como esses pais não morreram em serviço, os proventos correspondem a parte de seu salário. No entanto, mesmo antes da morte de seu pai, K. e sua família contavam com a ajuda dos avós maternos; mais tarde, com o novo casamento de sua mãe, também com a do padrasto e, mais recentemente, com recursos do trabalho da própria jovem. Já C. e sua família, desde a morte do pai, puderam contar com a assistência do tio, irmão da madrasta, além de, nos últimos tempos, tanto o irmão quanto ela e a mãe, terem começado a trabalhar.

Por fim, qualquer que tenha sido a dificuldade financeira acarretada pela morte dos pais dessas famílias, elas estavam sem dúvida muito mais amparadas financeiramente do que a maioria das famílias que perdem seu provedor, quer pelas pensões do Estado que passaram a receber, quer pelas bolsas de estudos a que os filhos tiveram direito na escola em que estudavam quando participaram deste estudo.

Além disso, deve-se acrescentar que, antes da morte desses pais, só a mãe de J. trabalhava, e, depois, só as mães de R. e C. passaram a trabalhar, e muito recentemente.

\section{Crença em vida após a morte}

K. e C. foram contraditórios com relação à crença em vida após a morte. K. disse que não acreditava, mas relatou vários episódios em que alguém da família lhe dizia que seu pai a estaria vendo de algum lugar, para persuadi-la a fazer algo que ela não queria - por exemplo, comer ou parar de chorar -, e o argumento acabava por convencê-la. C. também afirmou que não sabia se existia ou não vida após a morte, mas acredita que, mesmo morto, seu pai zela por ela e a protege, o que parecia fazê-la sentir-se mais confortada e fortalecida.

J. e M. admitiram que acreditam em vida após a morte. J. mostrou-se bem menos 
convicto do que M. e disse que, embora duvidasse que ao morrer fosse para o céu, se ele fosse e encontrasse o pai, seria ótimo. Entretanto, não deixou claro se a crença em vida após a morte ou se a expectativa que revelou o ajudavam a enfrentar a morte de seu pai.

M. foi mais taxativa ao dizer que acredita em vida após a morte - e não em reencarnação -, e deixou claro que essa crença a ajuda a aceitar o que aconteceu com seu pai, a elaborar uma explicação para o que houve com ele, dando um significado para sua morte e conforto para si mesma, ao enfatizar que ele estaria bem e sempre perto dela, protegendo-a.

Portanto, em geral, a crença em vida após a morte tem contribuído para dar um significado à morte, justificá-la ou confortar os enlutados, corroborando dados levantados por Franco (2000b), em sua pesquisa sobre fatores de risco para luto complicado numa população brasileira.

\section{Expressão de vivências relativas à perda e ao processo de luto}

M. foi a única que afirmou ter tido liberdade para se expressar quanto à perda de seu pai e a seu processo de luto, apesar de que, logo depois da morte do pai, quando se tocava no assunto, ela fugia. Mas as pessoas próximas conseguiram compreender seu constrangimento naquele momento, respeitaram suas limitações e, aos poucos, ela parou de fugir, circunstâncias que devem tê-la ajudado a enfrentar sua perda.

\section{Flexibilidade da estrutura familiar}

De acordo com os relatos dos jovens, a família de $\mathrm{C}$. foi a que mais revelou capacidade de se reorganizar após a morte de seu provedor, depois de um período inicial durante o qual seus membros ficaram em estado de choque, isolados uns dos outros. Essa capacidade pode estar ligada a várias características e condições específicas desse núcleo familiar como, por exemplo, o número de pessoas e as idades dos filhos na ocasião da perda, mas, entre as elas, pode-se destacar a flexibilidade de seus membros. De acordo com C., todos ali se deram conta da necessidade e, para resgatar a funcionalidade do núcleo familiar, se dispuseram a redistribuir entre si as funções que antes eram exercidas pelo falecido. 


\section{Grau de comunicação e de união entre os membros da família}

Outro aspecto que se destacou no relato de C. foi sua facilidade para se expressar, bem como o alto grau de comunicação entre ela e os demais membros da família, passado o choque inicial pela morte de seu pai. Isso sugere que, ao manter um canal aberto de comunicação, essa família tenha conquistado um grau de união que lhe permitiu efetivar os ajustes necessários para que o grupo familiar se reestruturasse de modo a se adequar à nova situação, advinda com a morte do pai de C., o que deve ter lhe favorecido a vivência de seu luto.

Pelos relatos de J. e de M., também em suas famílias a comunicação é estimulada, o que pode tê-los ajudado a atingirem o alto grau de união que ensejou a execução de medidas que possibilitaram a reestruturação do núcleo familiar com a conseqüente manutenção de sua funcionalidade.

Entretanto, nas famílias de R. e K., a comunicação não pareceu estar tão presente, o que deve ter comprometido o padrão de união e a necessária reorganização familiar.

De acordo com Walsh e McGoldrick (1991), que estudaram o luto da perspectiva do contexto familiar, levantaram alguns aspectos que deveriam ser observados, por sua influência no modo como os enlutados reagem à perda de um ente querido, entre eles, a flexibilidade da estrutura familiar, o grau de união entre os membros da família e a possibilidade de eles manterem entre si um canal aberto de comunicação.

\section{Presença de figuras substitutivas}

Especialmente no caso de C., J. e M., com o tempo, suas mães acabaram substituindo a figura paterna em suas funções, ou estas foram redistribuídas entre os demais membros da família, o que pode resgatar a funcionalidade dessas famílias. No entanto, R. não mencionou qualquer reorganização em sua família, comentando apenas que sempre contou com seu pai para ajudá-lo a fazer as tarefas escolares que levava para casa e que agora as fazia sem a ajuda de ninguém. K., por sua vez, enfatizou a impossibilidade de sua mãe assumir junto aos filhos até mesmo suas próprias atribuições, o que sugere que lhe seria possível responsabilizar-se por qualquer tarefa adicional que antes ficasse a cargo do marido. 


\section{Presença de modelos de identificação positiva (e de proteção)}

J. parece ter tido na irmã, seis anos mais velha que ele, um modelo de identificação positiva, espelhando-se em sua postura não só para enfrentar a crise decorrente da morte do pai, como também para determinar seu modo de se preparar para lidar com seu futuro. Já M. se mostrou bastante identificada com o pai, ao perceber-se como muito parecida com ele, física e psicologicamente, percepção que fica suspeita dada a idealização dessa imagem, mas que pode tê-la feito sentir-se fortalecida e protegida.

\section{VI.6 ESTRATÉGIAS DE ENFRENTAMENTO}

Quanto às estratégias utilizadas pelos jovens no enfrentamento da perda que sofreram, observaram-se certas similaridades; por exemplo, tanto J. quanto R. e mesmo C. contaram que procuravam se distrair para evitar pensar no assunto.

J. disse que procura adotar um "comportamento decente", isto é, não só ele procura se ocupar e distrair com outros assuntos, mas tampouco se deixa abalar pela situação, tentando aceitar o inevitável, pois, mais cedo ou mais tarde, todo mundo morre. R. procura não pensar e seguir em frente, provavelmente espelhando-se no exemplo da mãe.

À estratégia de se distrair para não pensar na morte do pai, C. acrescentou outras, mais sofisticadas, como procurar ser "forte" e apoiar sua família, seguindo o conselho que recebeu de uma amiga, ou aprender a sempre identificar e valorizar os aspectos positivos das situações que vivencia, o que, no caso da morte de sua mãe, seria a possibilidade de ela de ter três famílias e, no caso da morte de seu pai, o fato de ela ter mais liberdade para passar por diferentes experiências na vida, não ficando tão restringida como ocorria quando ele era vivo.

M. também procurou ser forte para apoiar a mãe e disse que as mudanças que decorreram da morte do pai exigiram que ela amadurecesse para se adaptar a sua nova realidade, além de ter em mente que precisa viver a vida no presente. Também parecem ter sido muito importantes os sonhos freqüentes que ela tem com o pai, principalmente quando se aproxima a data de sua morte - para M., eles significam que ele está sempre perto dela, protegendo-a.

Falando sobre os recursos que a teriam ajudado a enfrentar a morte de seu pai, a princípio, a jovem $\mathrm{K}$. contou que se apegava a suas lembranças - fotos, vídeos e a boneca que ganhou dele pouco antes de sua morte -, mas logo em seguida ficou um pouco insegura e pensativa, disse que não sabia o que tinha feito e concluiu que não tinha feito nada. 
Algumas das estratégias de enfrentamento utilizadas pelos jovens deste estudo também foram relatadas por Domingos (2000), em sua investigação a respeito das vivências de morte e de luto em escolares de 13 a 18 anos, tais como a evitação, a negação e o pensamento positivo. Entretanto, entre os participantes desta pesquisa, alguns não conseguiram se posicionar a esse respeito, o que pode indicar que eles não conseguiram de fato fazer o necessário enfrentamento.

\section{VI.7 REPERCUSSÕES DA PERDA PARA O ADOLESCENTE E SEU DESENVOLVIMENTO}

Entre os jovens que participaram deste estudo, R. foi o único que teve dificuldade de falar sobre as repercussões da morte do pai em sua vida, exceto pelo fato de que não podia mais contar com ele para acompanhá-lo ao futebol ou para ajudá-lo com as lições da escola, que agora ele faz sem ajuda de ninguém. Na maior parte do tempo, frisou que nada mudara em sua vida depois que seu pai morreu e, quando perguntado diretamente sobre o assunto, R. afirmou que tinha pensado muito sobre isso, mas não sabia dizer especificamente o quê.

No entanto, observa-se que muitas das repercussões relatadas pelos adolescentes deste estudo, quanto a sua representação sobre si mesmo, sobre o outro, sobre a vida e o mundo mostram que eles se tornaram mais maduros, mais conscientes de suas responsabilidades e das limitações da vida, embora, em alguns casos, eles tenham revelado dificuldades para confiar na vida e no outro e a tendência a assumirem mais responsabilidades do que lhes compete ou do que seria desejável.

\section{Representações atuais sobre si próprio}

J. se revelou bastante exigente e rígido consigo, procurando ser quem ele imagina que seu pai gostaria que ele fosse, mas contando também que, quando percebe que não consegue atingir esse seu objetivo, ele se ressente do fato de o pai não estar presente para aconselhá-lo a agir de forma mais adequada, que parece ser pautada pelos valores que eram do pai.

K. se reconhece chorona e se sente extremamente ameaçada pela possibilidade de vir a perder um de seus entes queridos. Além disso, em vários momentos da entrevista, ela demonstrou insegurança quanto à sua capacidade frente a situações diversas como responder às perguntas da pesquisa, identificar sentimentos que a perda de seu pai possa evocar - no passado ou no presente - ou quanto ao fato de ter ou não amigos. 
Diferentemente de K., M. e C. se percebem de forma bastante positiva, especialmente esta. Nesse sentido, M. e C. disseram que precisaram ter muita força para enfrentar a morte do pai, o que lhes demandou amadurecerem mais depressa. Além disso, C. se declarou independente e segura; em certos momentos, um tanto auto-suficiente, aspectos que apareceram no contato comigo.

\section{Representações atuais sobre o outro}

A percepção que J. tem do outro é marcada pela desconfiança, visão provavelmente ligada ao fato de seu pai ter sido assassinado, segundo o próprio jovem.

Já K., cujo pai também foi assassinado, também revelou dificuldade para fazer um julgamento apropriado do outro, mas adotou um outro estilo, ao demonstrar que mantém uma imagem idealizada dos pais.

Por outro lado, C. e M. enalteceram a importância de estar junto das pessoas. C. ressaltou que se empenhava para ter um amplo círculo de contatos, especialmente rapazes, e M. enfatizou que se esforçava para se relacionar melhor com as pessoas, tentando brigar menos, escutar mais, admitir seus erros e não se calar, mas expressar suas idéias.

\section{Representações atuais sobre a vida em geral}

Quanto à sua visão do mundo, J. também apresentou uma percepção contaminada pela trágica morte do pai, ao revelar que, na sua opinião, o mundo é violento e pouco confiável, enquanto K. admitiu que só recentemente passou a questionar a morte e a apreender o verdadeiro significado da vulnerabilidade e da finitude do ser humano.

C. disse que, ao perder seu pai, aprendeu que a morte é o limite da vida - o pior que pode lhe acontecer -, o que a fez passar a procurar viver um dia de cada vez e a não se preocupar desnecessariamente, como ela observa que fazem outros jovens quando se desentendem nos namoros ou discutem com os pais "por bobagem".

M. reconheceu que passou a valorizar mais sua família.

\section{Expectativas sobre o futuro}

Com relação a seu futuro, J. anunciou que vai procurar fazer o melhor, na expectativa de que seu pai, de onde estiver, possa ter orgulho dele. Disse também que, quando tiver seus 
filhos, vai procurar dar a eles tudo o que não pôde ter, sendo um pai atencioso e fazendo por eles o que for possível, preocupação semelhante à de K., que pretende ter com os filhos uma postura diferente da que sua mãe tem para com ela.

C. e M. manifestaram uma preocupação comum quanto ao futuro: ambas sentem que, por serem órfãs de pai, já não têm o mesmo amparo que teriam se tivessem pai vivo, o que as torna mais responsáveis pelo que venha a lhes acontecer daqui para a frente. Nesse sentido, C. foi categórica ao afirmar que, quando quiser alguma coisa, precisará lutar para conquistá-la, ao passo que $\mathrm{M}$. frisou a necessidade de planejar e cumprir metas para atingir seus objetivos.

\section{Estruturação familiar atual}

As famílias de J., C. e M. puderam se reorganizar de modo a se adaptarem às condições que sobrevieram com a perda de seu provedor, pois, apesar das dificuldades iniciais dessas mães e da madrasta de C., cada uma delas passou a assumir as funções antes exercidas pelo marido, ou as delegou aos filhos, ou as dividiu entre os membros da família, resgatando a funcionalidade do núcleo familiar.

Nesse contexto, parece que, para J., sua irmã representou um modelo não só para o enfrentamento da morte do pai, mas também para a organização da vida, embora ele tenha admitido que sente falta de conversar com alguém do mesmo sexo, que, em alguns assuntos, a seu ver, o entenderia melhor.

Já C. e M. se mostraram dispostas a assumir responsabilidades adicionais às que lhes cabem como filhas, pois a primeira cuida da irmã mais nova, às vezes até mais do que sua madrasta, a mãe da criança, e a segunda parece sentir-se mais responsável pela mãe do que por si mesma.

A situação de K. não é muito diferente, pois ela também passou a sentir responsabilidades que não the competiam: mostrou-se excessivamente preocupada com os irmãos e por pouco não assumiu para com eles atribuições que seriam de sua mãe. Entretanto, $\mathrm{K}$. tem uma condição bem diversa da dos demais jovens, vivendo num contexto familiar diferente. Apesar de seus pais terem participado de sua criação, desde pequena ela freqüentemente esteve sob os cuidados dos avós, situação que não se alterou com a morte de seu pai e a poupou de experimentar uma mudança tão intensa em sua organização familiar. Segundo a jovem, sua mãe sempre teve dificuldade para assumir suas responsabilidades para com os filhos, mas recentemente K. passou a ficar aflita com isso e muitas vezes a sentir-se responsável pelos irmãos e ressentida da ausência do pai, pois acredita que, se ele estivesse 
vivo, tudo seria diferente. Talvez K. também fique perturbada com essa situação por sentir-se culpada por ter tido a oportunidade de ser criada também por seus avós maternos, condição que seus irmãos não tiveram.

\section{VI.8 AVALIAÇÃO DAS ENTREVISTAS}

Quanto à participação na pesquisa, com exceção de R., que a princípio tinha decidido aceitar o convite por decisão da mãe, todos os outros se mostraram dispostos a cooperar, por entender que poderiam se beneficiar (K., C. e M.) ou beneficiar outros jovens (J.), ao falar sobre a morte de seu pai com um especialista com quem não conviviam.

Além disso, todos foram unânimes em admitir que se sentiram à vontade durante os procedimentos, mesmo quando não tinham respostas para as perguntas que lhes eram feitas, situação por que passou algumas vezes a jovem K. Para ela, ter sido convidada para participar deste estudo significou um privilégio e a fez sentir-se especial, supondo ter sido escolhida entre todos os órfãos que estudavam em sua escola. Entretanto, também revelou que temia não saber responder ao que se lhe perguntaria, pois há momentos em que ela não sabe explicar o que sente, o que de fato aconteceu. Mas sua avaliação final da participação foi positiva, pois ela pôde falar sobre o que sabia a respeito da morte do pai.

J. já tinha sido entrevistado duas vezes a respeito da morte de seu pai, também por psicólogos, o que, segundo o jovem, não lhe causou nenhum constrangimento, já que já faz muito tempo que ele ficou órfão e ele acredita que, com seu exemplo, pode ajudar outros jovens a enfrentarem a mesma situação que ele viveu.

A princípio R. disse que aceitou o convite para participar da pesquisa porque sua mãe assim determinara, mas que depois decidiu vir por conta própria, embora não tenha sido convincente ao explicar o motivo que o levou a isso.

C. e M. acharam que seria importante conversar com um especialista sobre a perda que sofreram, tendo C. enfatizado que se sentia mais à vontade para falar sobre seus sentimentos com uma pessoa com quem não tinha contato habitualmente e M. agradecido o convite - que também pareceu considerar um privilégio - e a oportunidade de falar sobre a morte de seu pai.

Assim, a participação neste estudo parece ter dado à maioria desses jovens uma oportunidade de refletirem sobre a perda que viveram e atendido a uma sua expectativa de serem ouvidos e acolhidos por um profissional, quiçá favorecendo-lhes o processamento de uma série de informações e vivências até então evitadas ou pouco discutidas. 


\section{VI.9 YSR}

Os participantes revelaram ao YSR rotinas típicas da adolescência: eles auxiliam suas famílias nas tarefas domésticas (lavam a louça, fazem suas camas), participam de algum tipo de associação (igreja, grupos de jovens, de músicos), praticam esportes (principalmente natação, futebol e andar de bicicleta) e, exceto por K. têm pelo menos dois passatempos, como ficar no computador, sendo que, K. e C., além de estudarem, trabalham meio período.

Nos relacionamentos, todos relataram que tem pelo menos de dois a três amigos, com os quais se encontram no mínimo uma vez por semana, fora do horário da escola, de modo que acreditam que se relacionam com outros jovens de sua idade melhor do que a maioria de seus pares, exceto por K., que acredita ter dificuldades para se relacionar com outros jovens.

$\mathrm{Na}$ família, os participantes consideraram que em comparação com outros adolescentes, se relacionam com seus irmãos melhor que os demais, mas quando se trata de avaliar a relação que mantêm com suas mães, eles entendem que se relacionam com elas do mesmo modo que a maioria dos jovens da idade deles.

Quanto a conseguirem fazer coisas sem a ajuda de ninguém, K. reconheceu que têm dificuldades nesse sentido, J. e C. entendem que se conduzem como a maioria dos jovens da idade deles, enquanto que R. e M. acreditam que são mais autônomos do que seus pares.

Em relação ao desempenho escolar, os jovens revelaram que apresentam desempenho na média e acima da média, sendo que só K. e C. relataram que têm dificuldades, em matemática e em física, respectivamente.

No que diz respeito às diferentes escalas propostas pelo YSR, os jovens R. e C. não expressaram vivenciar nenhum tipo de problema, pois seus resultados em todas elas atingiram a faixa normativa.

Por sua vez, M. obteve índices que indicaram a presença de problemas que englobam principalmente conflitos internos do adolescente, que muitas vezes não são perceptíveis por outras pessoas, e problemas de ansiedade, ao obter resultados que alcançaram a faixa limítrofe nas escalas de Problemas internalizantes e na escala orientada pelo DSM-IV, Transtornos de ansiedade.

Já os jovens K. e J. reportaram mais problemas que a maioria dos jovens de 11 a 18 anos. K. revelou problemas especialmente quanto à ansiedade, depressão, queixas de ordem somática, problemas de relacionamento social e de atenção, enquanto J. demonstrou problemas de ansiedade, depressão, isolamento e de pensamento.

K. obteve resultados que atingiram a faixa normativa nas escalas: Atividades (que se 
refere a competências), Qualidades positivas, nas síndromes Isolamento/depressão, Problemas de pensamento, Comportamento de quebrar-regras e Comportamentos agressivos, bem como nas escalas orientadas pelo DSM-IV Problemas somáticos, Déficit de atenção/transtorno de hiperatividade, Transtorno de conduta e Transtorno opositor desafiante.

Nas escalas de Competência total, Total de Problemas e internalizantes, das síndromes Ansiedade/depressão, Problemas de atenção e nas escalas orientadas pelo DSM-IV Transtornos de ansiedade, obsessivos compulsivos e de estresse pós-traumático, os resultados apresentados por K. se situaram na faixa clínica, revelando problemas nessas áreas.

Os índices de K. nas escalas de competência Social, Problemas externalizantes, nas síndromes Problemas sociais e Queixas somáticas, bem como na escala orientada pelo DSMIV, Transtornos Afetivos, atingiram a faixa limítrofe, entre a normativa e a clínica, o que sugere dificuldades nesses âmbitos.

No caso de J., os escores obtidos por ele nas escalas Total de problemas e problemas Internalizantes, nas síndromes Ansiedade/depressão e nas escalas orientadas pelo DSM-IV, Transtornos de ansiedade, obsessivos compulsivos e de estresse pós-traumático alcançaram a faixa clínica, indicando a presença de problemas nessas áreas.

Nas síndromes Isolamento/depressão e Problemas de pensamento, e na escala orientada pelo DSM-IV Transtornos afetivos, ao atingir resultados que se situaram na faixa limítrofe, entre a normativa e a clínica, o jovem J. reportou dificuldades nesses âmbitos.

É fundamental lembrar que os resultados obtidos no YSR precisam ser considerados tendo em vista os limites deste instrumento, que por se tratar de um inventário autoadministrado, fica sujeito a condição do sujeito de fornecer informações fiéis a realidade que vivencia, o que não só implica em honestidade de sua parte como envolve sua condição de se perceber adequadamente.

No entanto, apesar das limitações que o YSR apresenta, este instrumento forneceu dados que, examinados a luz das entrevistas que foram realizadas, podem sugerir considerações importantes para a compreensão dos processos de lutos dos jovens que participaram deste estudo, análise que se fará a seguir.

\section{VI.10 BREVE SÍNTESE DE CADA CASO}

O fato de K. e J. apresentarem resultados no YSR que denunciam que eles vivenciam mais problemas que a maioria dos jovens de 11 a 18, notadamente problemas de ansiedade e 
depressão, entre outros, não pode ser entendido como uma conseqüência direta e exclusiva de sua perda parental precoce e traumática.

Entretanto, não se pode ignorar que na literatura esses problemas têm sido associados ao luto não resolvido, além de comporem um cenário que dificulta a vivência de qualquer crise e sugere a presença de riscos para o desenvolvimento emocional desses adolescentes, indicando a necessidade de uma investigação mais acurada sobre as repercussões que a perda do pai gerou para eles e como eles podem ressignificar essas mortes, mesmo depois de passados tantos anos (Balk; Corr, 1996). Nas entrevistas, ambos também demonstraram posturas e deram informações que corroboraram as suspeitas sobre a resolução desses lutos, ou pelo menos sobre as conseqüências dessas perdas para esses jovens, fundamentando as proposições mencionadas acima.

K., por exemplo, mostrou-se pouco confiante em relação a si mesma e ao outro, confusa quanto aos próprios sentimentos e julgamentos, demonstrando hipersensibilidade e extrema ansiedade em relação aos vínculos, o que faz supor que a perda de seu pai, mais especificamente, o modo como ela pôde vivenciar e enfrentar seu processo de luto também tenha contribuído para a instalação dos problemas que ela reportou no YSR.

Nesse sentido, de certa forma, o fato de K. se revelar, com o passar do tempo, mais ansiosa do que a maioria dos adolescentes de sua idade condiz com o que encontrou Worden (1996) num estudo longitudinal realizado com crianças e adolescentes norte-americanos que tinham perdido seus pais e que foram comparados com um grupo controle de crianças e de adolescentes que não estavam de luto.

Também as dificuldades de relacionamento reportadas por K. no YSR - com os pares, no relacionamento social em geral e em problemas externalizantes - confirmam conclusões de Worden (1996), que observou que adolescentes de luto têm mais dificuldade de integração com os outros do que os colegas não enlutados, por terem problemas para gerenciar uma das questões centrais do desenvolvimento nessa etapa do ciclo vital - o senso de pertencer,

Além disso, ao relatar que recentemente, após a morte do pai do namorado, passou a ter outra compreensão da morte de seu pai, K. deu indícios da presença do que Worden (1998) denominou reações de luto retardadas, inibidas, suprimidas ou postergadas, que ocorrem quando, mesmo que a pessoa tenha expressado uma reação emocional na época da perda, esta não foi suficiente para o desenlace do processo de luto, de modo que, numa perda subseqüente, a pessoa tem uma reação intensa e desproporcional, como se parte do luto anterior tivesse sido postergada e só então pudesse ser vivida. Parece ser o caso de K., que disse que a morte do pai nunca lhe pareceu tão danosa como agora. 
Evidentemente, não se pode desconsiderar o contexto familiar de K., que, por si só, independentemente da morte de seu pai, representa uma situação de risco para seu desenvolvimento, pela dificuldade de sua mãe em assumir seu papel com relação aos filhos, o que acabou criar-lhes uma situação de abandono assistido, e em menor grau para K., que conta com os avós maternos para substituírem, ao menos em parte, a ausência de seus pais.

Além disso, ainda é preciso reconhecer que o processo de luto vivido por K. foi atravessado por outros fatores que sabidamente implicam risco para luto complicado: o fato de ter perdido o pai ainda menina, aos 8 anos de idade, sua baixa auto-estima, a relação de dependência e proximidade que tinha com o pai, o fato de a perda ter sido inesperada, prematura e violenta, permeada por ocorrências não esclarecidas e pela suspeita de suicídio, a inabilidade de sua família em lhe dar suporte, mentindo-lhe sobre o que se passara, impedindo-a de participar dos rituais do funeral e não the propiciando condições para expressar seus sentimentos e suas emoções referentes à sua perda (Bowlby, 2004b; Franco; Mazorra; Tinoco, 2002; Bromberg, 2000; Worden, 1996).

J., por sua vez, revelou adotar uma postura rígida, ao se exigir a assunção de determinados comportamentos, semelhantes aos que ele imagina que seriam adotados por seu pai, ou que seu pai esperaria dele, além de ter admitido sentir dificuldade para confiar no outro, na vida e no mundo. Esse quadro faz pensar que, para J., a morte abrupta e violenta de seu pai, que inclusive provocou o adoecimento de sua mãe, que deprimiu, deve ter contribuído para uma falta de previsibilidade em sua vida, para sua necessidade exacerbada de controle e para sua dificuldade em confiar no outro e no mundo, comprometendo sua espontaneidade e sua criatividade em adotar valores próprios (Worden, 1996).

Também no caso de J., há vários fatores de risco para luto complicado: ter perdido seu pai menino, com menos de 5 anos de idade, a relação de dependência que ele tinha com o pai, a perda ter sido inesperada, prematura e violenta e permeada por fatos que não foram devidamente esclarecidos, o fato de não ter podido contar com o apoio de sua mãe, na época e por um bom tempo, pois ela deprimiu e não havia muito com quem contar, além dela, e, finalmente, por não ter tido conseguido expressar seus sentimentos e suas emoções referentes à sua perda (Bowlby, 2004b; Franco; Mazorra; Tinoco, 2002; Bromberg, 2000; Worden, 1996).

Além disso, quando se consideram as estratégias de enfrentamento utilizadas por esses jovens, K. tem dificuldade para se posicionar a esse respeito, e J. adota a evitação, ou procura "ser decente", ou seja, não se deixar abalar pela situação e ser na vida do jeito que ele imagina que seu pai gostaria. Assim, a ausência de estratégias ou o uso de recursos que apresentam 
aspectos mais rígidos parecem indicar a presença de ansiedade frente a essas perdas.

Com relação à repercussão da morte do pai nesses jovens, não se evidenciam aspectos que indiquem amadurecimento, mas as mudanças que relatam antes parecem caminhar no sentido se constituírem em posturas reativas e defensivas.

Um outro aspecto comum que pode ser ressaltado diz respeito à influência da morte dos pais na expectativa quanto à parentalidade: ambos declararam que pretendem dar aos filhos uma condição diferente da que tiveram, propiciando-lhes tudo o que não puderam ter como filhos.

Quanto aos jovens R. e C., cujos resultados no YSR ficaram todos na faixa normativa, indicando a ausência de problemas que demandassem maiores preocupações sobre seu estado mental, a articulação entre esses resultados e as informações obtidas por meio das entrevistas levanta algumas questões.

Saliente-se que o depoimento de R. foi marcado por sua dificuldade em falar sobre aspectos relativos à perda e suas conseqüências para ele. Na maior parte do tempo, ele adotou um discurso lacônico, enfatizando que a morte do pai não tinha causado nenhuma mudança em sua vida. Mesmo sobre como se sentiu depois dessa perda, R. foi bastante econômico, afirmando que só ficou triste por um mês e alegando a necessidade de se conter e de "viver a vida". A partir dessa sua postura na entrevista, cria-se a suspeita de que também no YSR ele tenha omitido ou deturpado informações, pautado numa percepção superficial das situações, o que comprometeria os resultados encontrados. Seja como for, não se pode desconsiderar que não há qualquer queixa ou preocupação com relação a esse jovem, seja da escola ou da família, e que ele parece cumprir suas obrigações de acordo com o esperado.

Embora pouco se possa dizer sobre suas estratégias de enfrentamento, as repercussões de sua perda para ele e para seu desenvolvimento, sua participação na entrevista ou mesmo sobre o apoio que ele afirma ter recebido, entre os fatores de risco para luto complicado, podem-se identificar o fato de ele ser adolescente por ocasião da morte do pai, com quem tinha uma relação bem próxima, possivelmente de dependência, e de ter havido um assassinato, em circunstâncias que não foram completamente esclarecidas e sobre o qual R. não pode se expressar livremente.

Tem-se a impressão de que R. ainda não se deu conta plenamente de sua perda e de suas repercussões para ele e para sua família, como se seu processo de luto tivesse sido postergado, mantendo ainda uma postura passiva e dependente, não revelando que a morte de seu pai possa ter favorecido seu amadurecimento.

Situação bem diferente é a das jovens C. e M., cujos resultados no YSR também 
ficaram na faixa normativa, mas que nas entrevistas revelaram que a morte dos pais lhes deu a oportunidade de amadurecerem, representando experiências de aprendizagem e crescimento pessoal, tornando-as mais responsáveis, mais autônomas, empreendedoras e com uma perspectiva da vida mais realista e positiva, observando-se coerência entre o YSR, a postura dessas jovens nos contatos e o conteúdo de suas entrevistas.

No YSR, M. chegou a apresentar um resultado limítrofe na escala Problemas internalizantes, o que indica a presença de problemas que englobam principalmente conflitos internos, muitas vezes imperceptíveis para as pessoas, e, na escala orientada pelo DSM-IV, Transtornos de ansiedade, o que sugere a possibilidade de problemas nesse âmbito.

No entanto, frente aos outros dados obtidos na análise desse caso, bem como da prevalência de fatores de proteção para o luto complicado, principalmente o fato de ela e a mãe contarem com uma rede social de apoio, através da família extensa, da união e da comunicação que se estabeleceu entre as duas, da participação de M. nos rituais dos funerais do pai e do fato de ela ter podido expressar suas vivências de luto, de acordo com suas possibilidades, assim como de sua crença em vida após a morte.

Quanto a C., também se sobressaem os fatores de proteção para luto complicado, representados pelo tipo da morte de seu pai - anunciada - e pela ausência de mistérios acerca dela, bem como pela possibilidade de a jovem contar com suportes sociais expressivos, mas sobretudo pela estrutura de seu núcleo familiar, que, após o impacto que se seguiu à morte do pai, revelou flexibilidade, tendo seus membros estabelecido um canal de comunicação efetivo e um padrão de união que lhes possibilitou se reorganizarem e manterem a funcionalidade familiar. 


\section{CONSIDERAÇÕES FINAIS}

O luto representa o protótipo das crises da vida e, a partir deste estudo, evidencia-se que a perda por morte do pai biológico é e se mantém sempre significativa, em qualquer tempo, pela relevância do papel e do significado dessa figura, implicando a vivência do luto como um processo particular, mas cuja ressignificação depende de muitos fatores e de como se inter-relacionam. Entre eles, o primeiro é a etapa do ciclo vital em que se encontra o enlutado, com suas demandas e recursos específicos (Pereira, 2004; Domingos, 2000).

$\mathrm{Na}$ adolescência, pelos desafios singulares que passam os adolescentes, o luto, apesar de se assemelhar ao dos adultos, tem especificidades ainda não muito conhecidas, mas que têm merecido a atenção dos pesquisadores, em função das conseqüências que podem acarretar para o desenvolvimento do adolescente e para sua vida futura. Sabe-se que os efeitos do luto são severos e sua não resolução tem sido associada à depressão, à ansiedade excessiva e à presença de doenças crônicas, bem como a reações intensas de culpa e prejuízos na autoestima, no desempenho escolar, no exercício profissional e nas relações interpessoais (Balk; Corr; 2001).

Assim, há também que considerar que a adolescência é um período que também comporta fases - pré-adolescência (entre 10 e 14 anos), adolescência média (15-17) e tardia (18-22) - com características específicas, implicando a transição bem sucedida da adolescência média para a tardia o aumento do self, a aceitação de responsabilidades e da direção na vida, permeada pelo desafio de se determinar um caminho ou foco para o trabalho como adulto, pela aquisição de autonomia e pela manutenção de relacionamento e amizades íntimas (Balk, 2000).

Portanto, dos adolescentes estudados, que se encontram entre o final da adolescência média e o início da tardia, espera-se que demonstrem crescente maturidade na tomada de decisões e ampliem suas relações com seus pares, afastando-se mais de sua família de origem, especialmente dos pais. Nessa fase, as questões sobre identidade pessoal se tornam proeminentes para muitos deles, e o luto pela morte do pai não pode deixar de ser extremamente marcante e assumir caráter bem específico.

No entanto, apesar de a morte do pai biológico representar uma crise, também pode ser uma oportunidade para que, através de soluções criativas, aspecto reconhecidamente presente nessa etapa da vida (Sakamoto, 2005), o jovem não só enfrente essa perda, mas que também amadureça e faça aquisições pertinentes a esse período, importantes para seu desenvolvimento exitoso, com o cumprimento das tarefas que lhe impõe a vida nesse momento. 
No enfrentamento desse luto, tendo em vista a ressignificação dessa perda, os relatos dos adolescentes órfãos de pi deste estudo apontaram a relevância de inúmeros fatores que favorecem ou comprometem essa vivência, ratificando resultados de pesquisas de autores nacionais (Caselatto, 2005; Pereira, 2004; Bromberg, 2000; Domingos, 2000; Franco; Mazorra; Tinoco, 2002) e internacionais (Hurd, 2004; Balk; Corr; 2001; Liotta, 1996; Worden, 1996).

Como facilitador da vivência do luto, destaca-se o suporte social de uma rede de apoio que compreenda e atenda as necessidades do enlutado, na infância e na adolescência representados sobretudo pelo genitor sobrevivente, quando este se mantém funcional, mas também pela família extensa, por outros adultos e amigos. Nesse sentido, a escola tem se mostrado pouco eficaz, observando-se o despreparo de professores para lidar com essas questões.

Outros fatores também se evidenciam como promotores de condições que viabilizaram e facilitaram aos jovens o enfrentamento da morte de seus pais: características pessoais do enlutado (boa auto-estima, auto-eficácia e da condição de pensar positivamente através de suas experiências), mortes anunciadas, ausência de segredos sobre o óbito e suas circunstâncias, crença em vida após a morte e possibilidade de participar dos rituais de luto, quando se sentir preparado, e ser estimulado e respeitado na sua livre expressão sobre essa morte.

Entretanto, não se pode negar que a perda vivida por esses adolescentes tenha eliciado reações de tristeza intensa, negação e revolta, em função da angústia e da vivência de desamparo que foram suscitadas não só pela perda em si, mas também pelas perdas que dela decorreram, e que a necessidade de enfrentar essa crise provocou o uso de não só de recursos mais construtivos como o pensamento positivo e a crença em vida após a morte, como trouxe à tona estratégias mais danosas como a evitação (negação) e adoção de posturas mais rígidas, cujo prolongamento pode acarretar prejuízos à saúde mental e impedir que o luto e suas conseqüências sejam reconhecidos para ser de fato enfrentados.

Nesse contexto, deve-se avaliar a eventual necessidade de se proporem formas de cuidado específicas para os enlutados, que abarcam inúmeras possibilidades terapêuticas, ainda que profiláticas, em relação à vivência desse luto. $\mathrm{O}$ aconselhamento, o apoio social, que pode ser providenciado na própria comunidade, mesmo que informalmente, e em grupos de auto-ajuda, não só para os jovens enlutados, mas também para suas famílias, ou mesmo iniciativas que promovam na sociedade ocidental uma revisão de sua concepção sobre a morte e o luto, pela educação, são meios que devem ser cogitados, sem se desconsiderar que, para 
algumas situações, são recomendadas a consulta terapêutica e a psicoterapia.

Reconhece-se ainda que a morte dos pais dos adolescentes estudados causou profundas modificações em suas vidas, com repercussões sempre importantes quanto ao modo de esses jovens de se perceberem e perceberem o mundo e seu futuro; algumas mais positivas, que fomentam uma visão mais realista da vida e uma postura mais responsável, outras, não, com a prevalência de sentimentos de alienação, insegurança, desconfiança e auto-exigência exacerbada.

Finalmente, indica-se a necessidade da realização de outros estudos, com o uso de metodologias diversificadas, quantitativas e qualitativas, em que se proponham acompanhamentos longitudinais, o uso de grupos controle, com indivíduos não enlutados, e nas quais se considerem, além das demandas e dos efeitos do luto, os desafios e as transições do desenvolvimento da adolescência, bem como as contribuições que podem dar os estudos sobre resiliência em adolescentes. Pesquisas como essas certamente podem elucidar questões ainda pouco conhecidas, assim como levantar novas questões sobre o tema. 


\section{REFERÊNCIAS BIBLIOGRÁFICAS}

ABREU, C. N. de. Teoria do apego: fundamentos, pesquisas e implicações clínicas. São Paulo: Casa do Psicólogo, 2005.

ACHENBACH, T. M. Manual for the Youth Self-Report and Profile. Burlington, VT: University of Vermont, Department of Psychiatry, 1991.

Achenbach System of Empirically Based Assesment. Disponível em: $<$ www.aseba.org>. Acesso em: 29 set. 2007.

ARIĖS, P. História social da criança e da família. Rio de Janeiro: Zahar, 1986.

O homem diante da morte. Rio de Janeiro: Francisco Alves, 1982.

História da morte no Ocidente. Rio de Janeiro: Francisco Alves, 1977.

BALK, D. E. Adolescents, Grief and Loss. In: DOKA, K. J. Livinig with Grief: Children, Adolescents, and Loss. Washington, DC: Hospice Foundation of America, 2000. p. 35-50.

BALK, D. E.; CORR, C. A. Bereavement during adolescence: a review of research. In: Stroebe, M. S.; STROEBE, R. O. W.; SCHUT, H. Handbook of Bereavement Research: consequences, coping and care. Washington: United Book Press, 2001. p. 199-218.

BAKER, J. E. Minimizing eh Impact of Parental Grief on Children: Parent and Family Interventions. In: FIGLEY, C. R.; BRIDE, B. E.; MAZZA, N. Death and Trauma: The Traumatology of Grieving. Washington, DC: Taylor \& Francis, 1997. p. 17-41.

BATISTA PINTO, E. A pesquisa qualitativa em Psicologia Clínica. Psicologia USP, São Paulo, v.15, n.1, p. 85-93, 2004.

BLACK, D. Berevement. In: RUTTER, M.; TAYLOR, E. (Ed.). Child and Adolescent Psychiatry. Oxford: Blackwell Science Ltd., 2002. p. 299-308. 
BLEGER, J. A entrevista psicológica. In: BLEGER, J. Temas de psicologia: entrevista e grupos. São Paulo: Martins Fontes, 1980. p. 7-51.

BOWLBY, J. (1907) Separação: angústia e raiva. In: Apego e perda, v.2. São Paulo: Martins Fontes, 2004a.

(1907) Perda: tristeza e depressão. In: Apego e perda, v.3. São Paulo: Martins Fontes, 2004b.

(1907) Apego: a natureza do vínculo. In: Apego e perda, v.1. São Paulo: Martins Fontes, 2002.

(1907) Formação e rompimento dos vínculos afetivos. São Paulo: Martins Fontes, 1997.

BROMBERG, M. H. P. F. (Org.). Vida e morte: laços de existência. São Paulo: Casa do Psicólogo, 1996.

CASEllato, G. Luto por abandono: enfrentamento e correlação com a maternidade. 2004. Tese (Doutorado em Psicologia Clínica) - Pontifícia Universidade Católica de São Paulo, São Paulo, 2004.

A psicoterapia em situações de perdas e luto. Campinas, SP: Livro Pleno, 2000.

CORR, C. A. What Do We Know About Grieving Children and Adolescents? In: DOKA, K. J. Livinig with Grief: Children, Adolescents, and Loss. Washington, DC: Hospice Foundation of America, 2000. p. 21-32.

DIAS, M. L. Suicídio: testemunhos do adeus. São Paulo: Brasiliense, 1991.

DOMINGOS, B. Vivências de morte e luto em escolares de 13 a 18 anos. 2000. Dissertação (Mestrado em Psicologia Escolar e Desenvolvimento) - Instituto de Psicologia, Universidade de São Paulo, São Paulo, 2000. 
DOMINGOS, B.; MALUF, M. R. Experiência de perda e de luto em escolares de 13 a 18 anos. Psicologia, Reflexão e Crítica, Porto Alegre, v.16, n.3, p. 577-589, 2003.

ERIKSON, E. H. O ciclo vital: epigênese da identidade (adolescência). In: ERIKSON, E. H. Identidade: juventude e crise, 1976. p. 128-141.

FRANCO, M. H. P. F. Uma mudança no paradigma sobre o enfoque da morte e do luto na contemporaneidade. In: Estudos avançados sobre o luto. Campinas, SP: Livro Pleno, 2002. p. 15-38.

FRANCO, M. H. P. F.; MAZORRA, L.; TINOCO, V. U. Fatores de risco para luto complicado numa população brasileira. In: FRANCO, M. H. P. Estudos avançados sobre o luto. Campinas, SP: Livro Pleno, 2002. p. 39-68.

FREUD, S. (1917 [1915]) Luto e melancolia. In: Obras Completas. Rio de Janeiro: Imago, 1996.

GARCIA, A. A dor de adolescer. In: O adolescente e a modernidade. Congresso internacional de psicanálise e suas conexões. Rio de Janeiro: Companhia de Freud, 2000. p. $157-163$.

GREGIO, C. Antes e depois do trauma: vivencia traumática e o mundo presumido. 2005. Dissertação (Mestrado em Psicologia) - Pontifícia Universidade Católica de São Paulo, São Paulo, 2005.

GROTBERG, E. H. Introdução: novas tendências em resiliência. In: MELILLO, A.; OJEDA, E. N. S. et alli. Resiliência: descobrindo as próprias fortalezas. Porto Alegre: ArtMed, 2005. p. 23-38.

GUTT, E. K. Perfil comportamental e competência social de crianças e adolescentes filhos de mulheres com esquizofrenia. 2005. Dissertação (Mestrado em Psiquiatria) Faculdade de Medicina da Universidade de São Paulo, São Paulo, 2005. 
HAHN, R. A. A morte do pai na infância: repercussões na vida adulta. In: MAZORRA, L.; TINOCO, V. Luto na infância: intervenções psicológicas em diferentes contextos. Campinas, SP: Livro Pleno, 2005. p. 203-223.

HURD, R. C. A Teenager Revisits Her Father's Death During Chilhood: A Study in Resilience and Healthy Mourning. Family Therapy, San Diego, v.31, n.3, 2004, p. 167184.

HOROWITZ, M. J. et alii. Diagnostic for Complicated Grief Disorder. Am J Psychiatry, San Francisco, v.154, n.7, p. 904-910, July 1997.

IBGE. Tabela 1.1.1 - População residente, por cor ou raça, segundo a situação do domicílio e os grupos de idade - Brasil. Disponível em $<$ http://www.ibge.gov.br/home/estatistica/populacao/censo2000/primeiros_resultados_am ostra/brasil/pdf/tabela_1_1_1.pdf>. Acesso em: 7 ago. 2008.

KLOSINSKY, G. A adolescência hoje: situações, conflitos e desafios. Petrópolis, RJ: Vozes, 2006.

KOVÁCS, M. J. Morte e desenvolvimento humano. São Paulo: Casa do Psicólogo, 1992.

KUBLER-ROSS, E. Sobre a morte e o morrer. São Paulo: Martins Fontes, 1989.

KUCZYNSKI, E. Evolução puberal. In: ASSUMPÇÃO JR., F. B.; KUCZYNSKI, E. (Ed.). Adolescência normal e patológica. São Paulo: Lemos Editorial, 1998. p. 25-32.

LABORATÓRIO de Terapia Comportamental do Instituto de Psicologia da Universidade de São Paulo. (Trad.). (2006). Guia para profissionais da saúde mental sobre o Sistema de Avaliação Empiricamente Baseado do Achenbach (ASEBA). São Paulo. Tradução da obra: Achenbach, T.M., \& Rescorla, L.A. (2004). Mental Health practitioners' guide for the Achenbach System of Emprically Based Assessment (ASEBA) (4th ed.). Burlington, VT: University of Vermont, Research Center for Children, Youth, \& Families, Burlington, VT. Tiragem de circulação interna. 
LAPLANCHE, J.; PONTALIS. Vocabulário de Psicanálise. São Paulo: Martins Fontes, 2000.

LAVILlE, C.; DIONNE, J. A construção do saber: manual de metodologia da pesquisa em ciências humanas. Belo Horizonte/Porto Alegre: Artmed/Editora da UFMG, 1999.

LIOTTA, A. J. When students grieve: A Guide to Bereavement in the Schools. Pennsylvania: L. R. P. Publications, 1996.

MARANHÃO, J. L. de S. O que é morte. São Paulo: Brasiliense, 1998, Col. Primeiros Passos.

MARTINS, J.; BICUDO, M. A. V. A pesquisa qualitativa em psicologia. São Paulo: Moraes/Educ, 1988.

MAZORRA, L. O luto na infância. In: MAZORRA, L.; TINOCO, V. Luto na infância: intervenções psicológicas em diferentes contextos. Campinas, SP: Livro Pleno, 2005. p. $17-34$.

MINAYO, M. C. de S. O desafio do conhecimento: pesquisa qualitativa em saúde. São Paulo/Rio de Janeiro: Hucitec/Abrasco, 2000.

MOTA, M. M. de A. A psicoterapia breve na orientação profissional do jovem com deficiência física. 2003. Dissertação (Mestrado em Psicologia Clínica) - Instituto de Psicologia, Universidade de São Paulo, São Paulo, 2003.

MUNIZ, S. S. S. Morte materna na infância e vínculos amorosos na adolescência. 2004. Dissertação (Mestrado em Psicologia) - Pontifícia Universidade Católica de São Paulo, São Paulo, 2004.

NADER, K. O. Childhood Traumatic Loss: The Interaction of Trauma and Grief. In: FIGLEY, C. R.; BRIDE, B. E.; MAZZA, N. Death and Trauma: The Traumatology of Grieving. Washington, DC: Taylor \& Francis, 1997. p. 17-41. 
OLIVEIRA, T. M. de O psicanalista diante da morte: intervenção psicoterapêutica na preparação para a morte e na elaboração do luto. São Paulo: Editora Mackenzie, 2001.

OSÓRIO, L. C. Adolescente hoje. Porto Alegre: Artes Médicas, 1992.

OUTEIRAL, J. O. Adolescer: estudos sobre a adolescência. Porto Alegre: Artes Médicas, 1994.

PÁDUA, E. M. M. de. Metodologia da pesquisa: abordagem teórico-prática. Campinas, SP: Papirus, 2000.

PARKES, C. M. Luto: estudos sobre a perda na vida adulta. São Paulo: Summus, 1998.

Guidelines for Conducting Ethical Bereavement Research. Death Studies, v,19, 1995, p. 171-181.

Bereavement and mental illness. British Journal of Medical Psychology, v.38, n.126, 1965.

PEREIRA, K. M. Adolescência, luto e enfrentamento. 2004. Dissertação (Mestrado em Psicologia) - Pontifícia Universidade Católica de São Paulo, São Paulo, 2004.

OUTEIRAL, J. Adolescer: estudos revisados sobre a adolescência. Rio de Janeiro: Revinter, 2003.

RANGEL, A. P. F. N. Do que foi vivido ao que foi perdido: o doloroso luto parental. Tese (Doutorado em Psicologia Escolar e Desenvolvimento) - Instituto de Psicologia, Universidade de São Paulo, São Paulo, 2005.

REY, F. L. G. Pesquisa qualitativa em psicologia: caminhos e desafios. São Paulo: Thomson Pioneira, 2002.

RUTTER, M. Development and Psychopathology. In: RUTTER, M.; TAYLOR, E. (Ed.). Child and Adolescent Psychiatry. Oxford: Blackwell Science Ltd., 2002. p. 309-324. 
SAKAMOTO, C. K. Aladim e as mil e uma noites: uma discussão sobre a criatividade na adolescência. I Simpósio Internacional do Adolescente, 2005. Disponível em $<$ http://buscatextual.cnpq.br/buscatextual/visualizacv.jsp?id=K4782830T0 $>$. Acesso em: 7 ago. 2008.

SANDERS, C. Grief. The Mourning After: Dealing with Adult Bereveament. New York: John Wiley \& Sons, Inc., 1999.

SANDLER, I. Quality and Ecology of Adversity as Common Mechanisms of Risk and Resilience. American Journal of Community Psychology, v.29, 2001. Disponível em: $<$ http://www.questia.com/PM.qst?a=o\&d=5001032699>. Acesso em: 7 ago. 2008.

TOMMASI, M. C. Desenvolvimento emocional e cognitivo do adolescente. In: ASSUMPÇÃO JR., F. B.; KUCZYNSKI, E. (Ed.). Adolescência normal e patológica. São Paulo: Lemos Editorial, 1998. p. 33-47

TRIVINOS, A. N. S. Introdução à pesquisa em ciências sociais: a pesquisa qualitativa em educação. São Paulo: Atlas, 1992.

TUBERT, S. A morte e o imaginário na adolescência. Rio de Janeiro: Companhia de Freud, 1999.

TUBERT, S. O enigma da adolescência: enunciação e crise narcísica. In: O adolescente e a modernidade. Congresso internacional de psicanálise e suas conexões. Rio de Janeiro: Companhia de Freud, 2000. p. 23-39.

TURATO, E. R. Tratado de metodologia da pesquisa clínico-qualitativa: a construção teórico-epistemológica, discussão comparada e aplicação nas áreas da saúde e humanas. Petrópolis, RJ: Vozes, 2003.

WALSH, F.; MCGOLDRICK, M. Morte na família: sobrevivendo às perdas. Porto Alegre: ArtMed, 1998. 
WORDEN, J. W. Terapia do luto: uma manual para o profissional de saúde mental. Porto Alegre: Artes Médicas, 1998.

Children and Grief: When a Parent Dies. New York: Guilford Press, 1996. 


\section{ANEXO I}

UNIVERSIDADE DE SÃO PAULO

INSTITUTO DE PSICOLOGIA

DEPARTAMENTO DE PSICOLOGIA CLINICA

\section{TERMO DE CONSENTIMENTO PÓS-INFORMAÇÃO}

Obrigatório para pesquisa científica com seres humanos.

Resolução 196/96 - Conselho Nacional de Saúde.

\section{DADOS DE IDENTIFICAÇÃO DO SUJEITO DA PESQUISA OU RESPONSÁVEL LEGAL}

1. NOME DO PARTICIPANTE:

DOCUMENTO DE IDENTIDADE $\mathrm{N}^{\circ}$ :

SEXO: M F

DATA DE NASCIMENTO:

ENDEREÇO:

$\mathrm{N}^{\mathrm{o}}$

APTO.......

BAIRRO:

CIDADE:

CEP

TELEFONE: (.......)

2. RESPONSÁVEL LEGAL:

NOME:

NATUREZA (grau de parentesco, tutor, curador, etc.).

DOCUMENTO DE IDENTIDADE No: SEXO: M F

DATA DE NASCIMENTO:...........................

ENDEREÇO $\mathrm{N}^{\mathrm{o}}$ .APTO........

BAIRRO: CIDADE: CEP

TELEFONE: (.......) 


\section{DADOS SOBRE A PESQUISA CIENTÍFICA}

1. TÍTULO DO PROTOCOLO DE PESQUISA:

O luto na adolescência: o adolescente e a perda do pai por morte (pesquisa a ser desenvolvida como exigência do programa de Pós-Graduação em Psicologia Clínica do Instituto de Psicologia da Universidade de São Paulo para obtenção do grau de doutor).

2. RESPONSÁVEIS PELA PESQUISA:

2.1. PESQUISADORA: MONICA MARIA DE ANGELIS MOTA - PSC - IPUSP. FORMAÇÃO: PSICÓLOGA (doutoranda).

INSCRIÇÃO NO CONSELHO REGIONAL: CRP 06/27297-3.

2.2. ORIENTADORA: Profa Dra. ELIZABETH BATISTA PINTO WIESE.

UNIDADE DA USP: DEPARTAMENTO DE PSICOLOGIA CLÍNICA - USP.

3. AVALIAÇÃO DO RISCO DA PESQUISA (probabilidade de que o indivíduo sofra algum dano como conseqüência imediata ou tardia do estudo): NÃO HÁ RISCOS.

4. DATA DA APROVAÇÃO DO PROTOCOLO DE PESQUISA PELA “COMISSÃO DE ÉTICA PARA ANÁLISE DE PROJETOS DE PESQUISA":

5. DURAÇÃO DA PESQUISA: cerca de 2 horas.

6. LOCAL DE REALIZAÇÃO:

III. REGISTRO DAS EXPLICAÇÕES DO PESQUISADOR AO PARTICIPANTE E SEU REPRESENTANTE LEGAL SOBRE A PESQUISA, CONSIGNANDO:

Estou realizando uma pesquisa para estudar como o adolescente vivencia o luto pela morte de seu pai biológico. Conhecer e entender melhor sobre essa perda, e o modo do adolescente lidar com ela, pode ajudar na elaboração de recomendações para outros adolescentes e famílias na mesma situação, com o objetivo de facilitar a essas pessoas a superação de possíveis dificuldades relativas a essa perda. 
Para tanto, o jovem responderá a um questionário auto-aplicável, denominado de Youth Self Report - YSR (Inventário de Comportamentos Auto-referidos para jovens), e depois será entrevistado. Estas atividades devem durar cerca de 2 horas, e não oferecem riscos e nem desconforto para os sujeitos. No entanto, se necessário, e o jovem assim o desejar, o pesquisador se compromete a realizar uma segunda entrevista e se for o caso encaminhá-lo para um atendimento psicológico especializado, sem custo algum.

As entrevistas serão gravadas, sendo que as gravações, e os dados obtidos pelo questionário serão sigilosos e mantidos sob a responsabilidade da pesquisadora. Além disso, há o compromisso de se preservar a identidade do participante, e de se manter o caráter confidencial das informações relacionadas com a sua privacidade.

Os resultados obtidos na pesquisa poderão ser apresentados em reuniões científicas, e servirão para a formulação de minha tese de doutorado e para a redação de artigos científicos.

Você tem o direito de querer ou não participar dessa pesquisa, e se decidir realizar as atividades, em qualquer momento do trabalho, poderá falar que não quer mais participar da pesquisa e declinar sua participação.

\section{TERMO DE CONSENTIMENTO LIVRE E ESCLARECIDO}

Pelo presente instrumento, que atende às exigências legais, o (a) senhor (a)

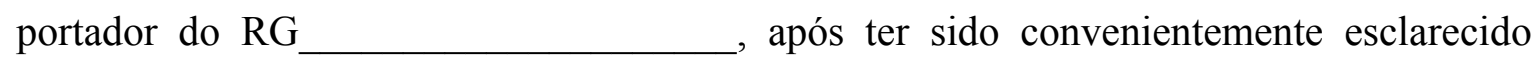
pelo pesquisador, e entendido o que lhe foi explicado, assina seu CONSENTIMENTO LIVRE E ESCLARECIDO de concordância e autorização para a participação de seu (sua) filho(a)

como sujeito na pesquisa "O adolescente e o luto pela morte do pai biológico", autorizando o uso científico dos dados obtidos na entrevista e pelo questionário YSR.

O presente termo é assinado em duas vias, ficando uma em seu poder.

São Paulo, de de 2007. 


\section{ANEXO II}

\section{ROTEIRO DA ENTREVISTA COM O ADOLESCENTE}

Introdução: Como já disse, eu estou fazendo uma pesquisa para estudar o que acontece com o adolescente quando ele perde seu pai. Inicialmente, eu gostaria de conversar um pouco com você, para conhecê-lo, antes de pedir-lhe que me conte sobre a morte de seu pai, e sobre como foi para você perdê-lo. É importante que você saiba que tudo o que falarmos ficará entre nós, e que somente usarei essas informações para estudos, sem que você possa ser identificado como quem as forneceu para mim.

1. Você estuda? Em que série você está? Gosta da escola? Na escola, do que gosta mais? E do que gosta menos? Há algo na escola de que você não goste?

2. Que outras atividades, além da escola, você tem?

3. Você tem muitos amigos? De onde você os conhece? Eles têm que idades?

4. Você namora? Há quanto tempo? Como ele (ela) se chama? Como a (o) conheceu? Que idade ele (ela) tem?

5. Com quem você mora atualmente (registrar grau de parentesco e idades das pessoas)?

6. Como é de seu conhecimento, eu sei que seu pai já morreu. E antes da morte dele, com quem você morava (registrar grau de parentesco e idades das pessoas)?

7. Como você soube da morte de seu pai?

8. Você soube da notícia imediatamente ou não?

9. Como você soube? Alguém contou? Ou soube de outra forma?

10. Conte-me o que houve com seu pai. 
11. Você testemunhou a morte dele?

12. Como você lidou com essa situação?

13. Logo depois de saber da morte de seu pai, como você se sentiu (sintomas, sentimentos, emoções)?

14. Essas reações persistiram? E ocorriam com que freqüência? Até quando elas duraram?

15. E após o período imediato da morte, outras reações apareceram? Quando? Com que freqüência? Até quando?

16. E que reações apareceram somente depois de algum tempo depois da morte dele?

17. Como sua família reagiu (investigar principalmente a reação da mãe)?

18. Suas dúvidas e curiosidades a respeito da morte dele foram esclarecidas?

19. Há algo que o deixa em dúvida sobre as causas ou circunstâncias da morte dele? Se há, explique para mim.

20. Há outros fatores envolvidos na morte sobre os quais você gostaria de falar?

21. Como você descreveria seu relacionamento com seu pai, antes da morte dele? E na época de seu falecimento?

22. Qual e como foi seu último contato com ele?

23. Por ocasião da morte de seu pai, qual era a participação dele em sua vida?

24. Como estava o relacionamento familiar na época da morte de seu pai? 
25. Você participou dos rituais do funeral (velório, sepultamento, celebrações religiosas, ou outros)? O que significou para você ter participado (ou, o que significou para você não ter participado?).

26. Você acredita em vida após a morte? Esta crença ajudou você a enfrentar sua perda? Como?

27. O que mudou em sua vida depois da morte de seu pai:

Em casa:

Na rotina diária:

Na escola:

Em seu relacionamento com sua mãe?

E nos relacionamentos com os outros (amigos, colegas, professores, familiares em geral)?

No seu comportamento:

28. Como ficou sua percepção do mundo/ da vida/ da morte/ e do seu futuro, depois da morte de seu pai? Houve mudanças? Quais?

29. Depois da morte dele, houve outras perdas (financeiras, sociais ou outras)?

30. O que mais aflige você em relação à morte de seu pai?

31. Você teve oportunidade (facilidade) de expressar e compartilhar sentimentos e emoções ligados à perda? Explique.

32. Você recebeu algum tipo de apoio? De quem (mãe, outros familiares, de amigos, na escola (professores e colegas), religioso, profissional, outro)? Como foi para você receber esse apoio?

33. Na época da morte de seu pai aconteceram outros fatos importantes? Quais?

34. As datas relacionadas a seu pai, e a sua morte são lembradas? O que acontece?

35. Hoje, como você avalia sua recuperação? 
36. O que você faz (fez) para se recuperar de sua perda? O que facilitou essa recuperação? O que dificultou?

37. Você teve recaídas? Quando? Explique o que aconteceu.

38. Que lembranças você guarda de seu pai na atualidade?

39. Hoje, o que você pensa dessa experiência? E como você se sente em relação a ela?

40. Que registro você tem hoje de seu pai?

41. Você já teve outras perdas significativas por morte? De quem? Quando? Como você reagiu?

42. O que o levou a aceitar o convite para participar desta pesquisa? O que você esperava desta entrevista? Como foi para você responder a essa entrevista?

43. Você gostaria de acrescentar mais alguma informação que considera importante? Ou falar mais alguma coisa? 


\section{ANEXO III}

\section{ENTREVISTA DE RETORNO}

\section{TEMAS ABORDADOS COM O ADOLESCENTE}

1. Impressões do jovem a respeito de sua participação nesta pesquisa: o que ele pensou ou sentiu sobre sua participação neste estudo, depois de ter respondido ao inventário e de ter sido entrevistado.

2. Possíveis reflexões que ele possa ter realizado depois de ter participado deste estudo: o que ele pensou sobre sua perda e seu luto após nosso primeiro encontro.

3. Permitir ao jovem que possa acrescentar informações, impressões e expressar sentimentos sobre tudo o que conversamos e sobre a própria experiência de ter participado nesta pesquisa.

4. O que ele achou de ter participado desta pesquisa. 
ANEXO IV 
ANEXO V 